UNIVERZITET U BEOGRADU

POLJOPRIVREDNI FAKULTET

mr Darko R. Jevremović

Rasprostranjenost PPV-D i PPV-Rec sojeva virusa šarke šljive (Plum pox virus) u Srbiji i dinamika njihovog širenja u zasadu šljive

doktorska disertacija

Beograd, 2012. 
UNIVERSITY OF BELGRADE

FACULTY OF AGRICULTURE

Darko R. Jevremović, MSc

Distribution of PPV-D and PPV-Rec strains of

Plum pox virus in Serbia and the dynamics of

their spread in plum orchard

Doctoral Dissertation

Belgrade, 2012 
MENTOR:

dr Branka Krstić, redovni profesor, Poljoprivredni Fakultet Univerziteta u Beogradu

\section{ČLANOVI KOMISIJE:}

dr Svetlana Paunović, naučni savetnik, Institut za voćarstvo, Čačak

dr Mirko Ivanović, redovni profesor, Poljoprivredni Fakultet Univerziteta u Beogradu

dr Aleksandra Bulajić, vanredni profesor, Poljoprivredni Fakultet Univerziteta u Beogradu

dr Olivera Petrović-Obradović, vanredni profesor, Poljoprivredni Fakultet Univerziteta u Beogradu

Datum odbrane: 
Ova doktorska disertacija je nastala uz dragocenu pomoć nekoliko osoba kojima dugujem veliku zahvalnost.

Najiskrenije se zahvaljujem dr Svetlani Paunović, mom mentoru u Institutu za voćarstvo u Čačku. Zahvalan sam joj na nesebično prenetom znanju, podršci, korisnim savetima i sugestijama tokom izrade disertacije.

Zahvalnost dugujem dr Sylvie Dallot (INRA UMR BGPI, Monpelje, Francuska) za korisne smernice tokom sprovođenja eksperimenta i analize dobijenih rezultata. Dugujem joj i zahvalnost što mi je omogućila da radim u njenoj laboratoriji, u kojoj je obavljen deo molekularnih analiza.

Zahvaljujem se prof. dr Branki Krstić, svom profesoru i mentoru na Poljoprivrednom fakultetu, koja je svojim znanjem $i$ iskustvom značajno doprinela kvalitetu konačne verzije disetracije.

Zahvaljujem se i kolegama sa Instituta za voćarstvo koji su mi pomogli prilikom sakupljanja uzoraka i seroloških analiza: mr Aleksandru Leposaviću, dr Nemanji Miletiću, mr Svetlani M. Paunović, Branislavu Milinkoviću dipl. inž. i Mirjani Pajić hem. teh.

Zahvalnost dugujem i svojoj porodici, supruzi Dijani i ćerkama Ivi i Andrei, koje su moja najveća podrška i inspiracija.

Istraživanja prikazana u ovoj disertaciji urađena su u Institutu za voćarstvo u Čačku uz finansijku podršku Ministarstva provete i nauke Republike Srbije - projekat TR31064 i Evropske komisije - FP7 Projekat SharCo [European Community's Seven Framework Programme (FP7/2007-2013) under Grant Agreement n²04429].

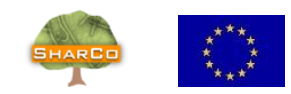




\section{Rasprostranjenost PPV-D i PPV-Rec sojeva virusa šarke šljive \\ (Plum pox virus) u Srbiji i dinamika njihovog širenja u zasadu šljive}

\section{Rezime}

Virus šarke šljive (Plum pox virus-PPV), prouzrokovač bolesti šarke šljive, je prisutan u Srbiji skoro 80 godina i smatra se ekonomski najznačajnijim virusom koštičavih voćaka. Od 7 opisanih sojeva PPV, u Srbiji je potvrđeno prisustvo tri soja: PPV-M, PPV-D i PPV-Rec.

U cilju utvrđivanja raširenosti sojeva šarke u zasadima šljive i kajsije $u$ Srbiji, u periodu 2008-2010. godine, standardizovanom procedurom je sakupljeno ukupno 283 uzoraka lišća šljive i kajsije iz preko 90 zasada. Tipiziranje detektovanih izolata sprovedeno je IC-RT-PCR metodom kroz 4 odvojene PCR reakcije sa PPV-M i PPV-D specifičnim prajmerima sa ciljnim sekvencama u dva regiona genoma. Za filogenetsku analizu i utvrđivanje stope diverziteta odabran je 41 izolat za sekvencioniranje fragmenata iz dva regiona genoma (C-ter NIb-N-ter CP i C-ter P3-6K1-N-ter CI).

U cilju ispitivanja dinamike širenja PPV-D i PPV-Rec sojeva u direktnoj kompeticiji, tokom 2008. godine podignut je eksperimentalni zasad sa 400 stabala šljive sorte Čačanska lepotica. Osam stabala, koja su locirana u sredini zasada, su inokulisana sa potpuno okarakterisanim PPV-D i PPV-Rec izolatima (4 stabla po izolatu-interni izvor infekcije). Sva stabla Prunus vrsta u neposrednoj okolini zasada su markirana, uzorkovana i testirana na prisustvo PPV (eksterni izvor infekcije). Pozitivni uzorci su sekvencionirani u C-ter NIb-N-ter CP regionu genoma za dalju uporednu analizu sa sekvencama inokulisanih i novoinficiranih stabala u zasadu. Svake godine, od 2008-2011., sva stabla u eksperimentalnom zasadu su vizuelno pregledana i ispitivana ELISA testom na prisustvo PPV. Pozitivni uzorci su tipizirani IC-RT-PCR metodom i sekvencionirani u C-ter NIb-Nter CP regionu genoma. Tokom poslednje tri godine istraživanja vršeno je praćenje prisustva i dinamike brojnosti lisnih vaši u eksperimentalnom zasadu. 
U zasadima šljive i kajsije u Srbiji dominantno je prisutan PPV-Rec soj (55,7\%), slede PPV-D soj (26,3\%) i PPV-M soj (5,4\%). U značajnom procentu $(12,6 \%)$ potvrđene su i mešane infekcije. U centralnim i zapadnim delovima Srbije dominantno je prisutan PPV-Rec soj, dok u jugoistočnim delovima dominira PPV-D soj. Sprovedena filogenetska i analiza genealoške povezanosti sekvenci je pokazala da ne postoji povezanost srodnih sekvenci PPV izolata sa geografskim poreklom izolata niti sa vrstom biljaka domaćina. Uzrok ovakvih rezultata se može objasniti nekontrolisanim širenjem izolata putem zaraženog sadnog materijala u ranijem periodu.

U eksperimentalnom zasadu su nakon četiri godine utvrđena 32 stabla zaražena PPV-Rec sojem i 5 stabala zaražena PPV-D sojem, što predstavlja 9,25\% od ukupnog broja stabala u zasadu. Uzimajući u obzir brojnost PPV-D i PPV-Rec izolata iz okoline zasada, dobijeni rezultati ukazuju na nešto efikasnije širenje PPVRec soja. Analizom sekvenci izolata sa inokulisanih, novozaraženih, kao i sa stabala iz neposredne okoline zasada, utvrđeno je da je izvor zaraze najvećeg broja stabala eksterni izvor infekcije. Nakon 4 godine, utvrđeno je samo jedno novozaraženo stablo sa PPV-Rec izolatom koji potiče iz internog izvora infekcije. Do pojave sekundarnih infekcija u zasadu dolazi u kasnijim godinama, ali bez pravilnosti $u$ lokaciji novozaraženih stabala u odnosu na izvor infekcije.

Istraživanja vrsta i brojnosti lisnih vaši su pokazala da oko 50 različitih vrsta posećuje zasad šljive. Značajan udeo čine vrste koje su potvrđeni vektori PPV, gde dominiraju vrste iz roda Aphis. Brojnost populacija lisnih vaši tokom ispitivanog perioda je značajno varirala. Utvrđeni termini najveće brojnosti su maj-jun i avgust-septembar.

Ključne reči: Virus šarke šljive, sojevi, ELISA, IC-RT-PCR, filogenetika, lisne vaši

Naučna oblast: Biotehničke nauke

Uža naučna oblast: Fitopatologija

UDK: 634.1.21:22;632.38 


\title{
Distribution of PPV-D and PPV-Rec strains of Plum pox virus in Serbia and the dynamics of their spread in plum orchard
}

\begin{abstract}
Plum pox virus (PPV), the agent of Sharka disease, is present in Serbia almost 80 years and it is considered as economically the most important virus of stone fruits. Three strains, out of 7 described, are present in Serbia: PPV-M, PPV-D and PPV-Rec.

In order to determine the prevalence of strains in plum and apricot orchards in Serbia during the three-year period (2008-2010), a total of 283 plum and apricot leaf samples from over 90 orchards were collected by standardized procedure. Strain-typing of isolates was done by IC-RT-PCR in 4 separate PCR reactions with PPV-M and PPV-D specific primers with target sequences in two different genomic regions. For phylogenetic analysis and determination of diversity rate, 41 isolates were selected for sequencing fragments from two genomic regions (C-ter NIb-N-ter CP and C-ter P3-6K1-N-ter CI).

In order to study the dynamics of spread of PPV-D and PPV-Rec strains in direct competition, an experimental plum orchard of 400 trees of Čačanska lepotica variety was built in 2008. Eight trees, which are located in the middle of the orchard, were inoculated with a fully characterized PPV-D and PPV-Rec isolates (4 trees per isolate-internal source of infection). All Prunus trees in the vicinity of the experimental orchard were marked, sampled and tested for the presence of PPV (external source of infection). Positive samples were sequenced in C-ter NIb-N-ter CP genomic region for further analysis with sequences of inoculated and newly infected trees in the orchard. Every year, from 2008-2011, all trees from the orchard were visually inspected and tested by ELISA for the presence of PPV. ELISA positive samples were typed by IC-RT-PCR and sequenced in the C-ter NIb-N-ter CP genomic region. During the last three years of research, the presence and the number of aphids in the experimental orchard were monitored.
\end{abstract}


PPV-Rec strain is predominantly present in plum and apricot orchards in Serbia (55.7\%), followed by PPV-D strain (26.3\%) and PPV-M strain (5.4\%). Mixed infections were confirmed in the substantively percentage (12.6\%). In central and western parts of Serbia PPV-Rec strain is predominant, while the PPV-D strain is dominantly present in south-eastern parts. Conducted phylogenetic and genealogical analysis of sequences showed no relationship of related sequences with the geographic or host origin of the isolates. The cause of these results can be explained by the uncontrolled spread of isolates through infected planting material in the past.

After four years, 32 trees infected with PPV-Rec strain and 5 trees infected with PPV-D strain were confirmed in the experimental orchard, which represents 9.25\% of total trees. Taking into account the number of PPV-D and PPV-Rec isolates from the close vicinity, the results indicate slightly efficient spread of PPVRec strain. Analysis of sequences of isolates from inoculated, newly infected, as well as from the trees from the surroundings, indicates that the majority of trees were infected from the external sources of infection. After 4 years, only one newly infected tree with PPV-Rec isolate that originate from internal source of infection was found. The emergence of secondary infections in the orchard comes in later years, but with no regularity in location of newly infected trees in relation to the source of infection.

Research on the aphid species and their number has shown that about 50 different species visits plum orchard, of which a significant proportion of species are described as PPV vectors, with the domination of Aphid spp. The number of aphid populations during investigated period varied considerably. Determined periods of the largest number of aphids are May-June and August-September.

Keywords: Plum pox virus, strains, ELISA, IC-RT-PCR, phylogenetics, aphids

Scientific discipline: Biotechnological Sciences

Scientific discipline as major: Phytopathology

UDK: 634.1.21:22;632.38 


\section{SADRŽAJ}

1. Uvod 1

2. Pregled literature 3

2.1. Rasprostranjenost virusa šarke šljive 3

2.2.0sobine virusa $\quad 4$

2.3. Sojevi 6

2.4. Simptomi 9

2.5. Domaćini 13

2.6. Načini prenošenja virusa 14

2.7. Detekcija i karakterizacija $\quad 15$

3. Ciljevi istraživanja 19

4. Materijal i metode 21

4.1. Ispitivanje prisustva i karakterizacija izolata virusa šarke iz zasada šljive $\begin{array}{ll}\text { i kajsije na teritoriji Srbije } & 21\end{array}$

4.1.1. Biljni materijal 21

4.1.2. Detekcija i tipiziranje izolata virusa šarke 22

4.1.2.1. Oblaganje ploča specifičnim antitelima 23

4.1.2.2. Priprema uzoraka i imunovezivanje virusa (Immunocapture - IC) 23

4.1.2.3. Reverzna transkripcija (Reverse Transcription - RT) 24

4.1.2.4. Lančana reakcija polimeraze (Polymerase Chain Reaction - PCR) 24

4.1.2.5. Analiza PCR proizvoda 27

4.1.3. Sekvencioniranje delova genoma odabranih izolata 28

4.1.4. Filogenetska analiza 29

4.2. Ispitivanje dinamike širenja sojeva šarke šljive, prisustva i brojnosti

lisnih vaši u eksperimentalnom zasadu šljive $\quad 31$

4.2.1. Eksperimentalni zasad $\quad 31$

4.2.2. Vizuelni pregledi 33

4.2.3. Serološki test potvrđivanja prisustva virusa 34

4.2.4. Molekularni test tipiziranja sojeva detektovanih izolata virusa šarke $\quad 35$

4.2.5. Filogenetska analiza 36

4.2.6. Praćenje brojnosti i vrsta lisnih vaši u eksperimentalnom zasadu 36

5. Rezultati 38

5.1. Rasprostranjenost sojeva šarke šljive u Srbiji 38

5.1.1. Rezultati IC-RT-PCR analiza 38

5.1.2. Rasprostranjenost sojeva šarke u uzorcima šljive $\quad 40$

5.1.3. Rasprostranjenost sojeva šarke u uzorcima kajsije 42

5.1.4. Zastupljenost sojeva šarke na nivou zasada 43

5.1.5. Rasprostranjenost sojeva na nivou okruga 44

5.1.6. Analiza nukleotidnih sekvenci C-ter Nib-N-ter CP i P3-6K1 regiona genoma $\quad 45$

5.1.6.1. Analiza sekvenci C-ter Nib-N-ter CP regiona genoma 46

5.1.6.2. Analiza sekvenci P3-6K1 regiona genoma genoma 53

5.2. Dinamika širenja sojeva šarke šljive, prisustvo i brojnost lisnih vaši u
eksperimentalnom zasadu šljive 
5.2.1. Ispitivanja prisustva virusa šarke u eksperimentalnom zasadu u prvoj godini istraživanja (2008. godina)

5.2.2. Ispitivanja prisustva virusa šarke u eksperimentalnom zasadu u drugoj godini istraživanja (2009. godina)

5.2.3. Ispitivanja prisustva virusa šarke u eksperimentalnom zasadu u trećoj godini istraživanja (2010. godina)

5.2.4. Ispitivanja prisustva virusa šarke u eksperimentalnom zasadu u $\begin{array}{ll}\text { četvrtoj godini istraživanja (2011. godina) } & 71 \\ & 80\end{array}$

6. Diskusija

6.1. Rasprostranjenost sojeva šarke šljive u Srbiji 80

6.1.1. Rasprostranjenost sojeva šarke u zasadima šljive i kajsije u Srbiji $\quad 80$

6.1.2. Sojevi virusa šarke šljive u zasadima šljive 82

6.1.3. Sojevi virusa šarke šljive u zasadima kajsije 83

6.1.4. Zastupljenost sojeva na nivou zasada $\quad 84$

6.1.5. Geografska distribucija sojeva šarke 84

6.1.6. Analiza nukleotidnih sekvenci C-ter Nib-N-ter CP regiona 85

6.1.7. Analiza nukleotidnih sekvenci P3-6K1 regiona 89

6.2. Dinamika širenja sojeva šarke šljive, prisustvo i brojnost lisnih vaši u eksperimentalnom zasadu šljive

6.2.1. Ispitivanje prisustva virusa šarke u eksperimentalnom zasadu u prvoj godini istraživanja (2008. godina)

6.2.2. Ispitivanje prisustva i distribucije virusa šarke u eksperimentalnom zasadu u drugoj godini istraživanja (2009. godina)

6.2.3. Ispitivanje širenja virusa šarke u eksperimentalnom zasadu u trećoj godini istraživanja (2010. godina)

6.2.4. Ispitivanje dinamike širenja i prostorne distribucije virusa šarke u eksperimentalnom zasadu u četvrtoj godini istraživanja (2011. godina) 


\section{UVOD}

Šljiva zauzima značajno mesto u strukturi voćarske proizvodnje Srbije. Prema podacima o proizvodnji plodova šljive u periodu 2009-2011. godine, u Srbiji se prosečno proizvodi 557.117 t plodova šljive (Republički zavod za statistiku $R S$ ), dok je svetski rekorder Kina sa proizvodnjom od preko 5,3 miliona tona $\mathrm{u}$ 2009. godini (FAOSTAT). Povoljni zemljišni i klimatski uslovi, ekonomska korist i tradicija gajenja i prerade učinili su da je šljiva već čitav vek vodeća voćna vrsta u Srbiji. I pored niskih cena i velikih kolebanja u različitim godinama, nije napušteno gajenje šljive. Porast tražnje svežih plodova, posebno sorata sa ranijim vremenom zrenja, naročito za tržišta Ruske Federacije i zemalja zapadne Evrope, uticao je na podizanje novih zasada šljive.

Proizvodnja plodova breskve i kajsije je znatno skromnija. U 2009. godini u Srbiji je proizvedeno 77.230 t plodova breskve i 31.157 t plodova kajsije (FAOSTAT).

Redovan pratilac gajenja koštičavih voćaka je virus šarke šljive (Plum pox virus - PPV). Šarka šljive se smatra ekonomski najznačajnijom virusnom bolešću Prunus vrsta. Ogromne štete nanosi gajenju osetljivih sorti šljive, kajsije i breskve. Tačni i precizni podaci o broju zaraženih stabala Prunus vrsta koje su domaćini virusa šarke ne postoje. Po procenama koje datiraju od pre skoro 20 godina, $u$ Evropi je bilo zaraženo preko 100 miliona stabala (Roy i Smith, 1994). Za Srbiju se navodi pretpostavka da je oko $60 \%$ stabala šljive zaraženo virusom šarke (Ranković et al., 1994).

Pojava šarke ima ozbiljne agronomske, ekonomske i političke posledice. Smanjenje kvaliteta plodova, prinosa i prerano opadanje plodova su problemi koji 
se javljaju u gajenju šljive, kajsije i breskve. Osobina virusa šarke da se veoma efikasno prenosi lisnim vašima, otežava proizvodnju sadnica slobodnih od virusa šarke (PPV-free). Kontrola virusa uključuje koordinisane napore proizvođača, rasadničara, oplemenjivača, istraživača i državnih institucija.

Prema procenama, globalni troškovi koji su povezani sa virusom šarke Šljive, uključujući i indirektne troškove, premašuju 10 milijardi evra tokom poslednjih 30 godina (Cambra et al., 2006).

U Srbiji je šarka prisutna preko 70 godina i, pored ostalih faktora, dovela je do značajnih izmena strukture sortimenta šljive. Nekada dominantna sorta Požegača, danas je u sortimentu zastupljena sa manje od $30 \%$ i to prevashodno $u$ starim i napuštenim zasadima. U voćnjacima šljive danas dominira sorta Stenley i sorte stvorene u Institutu za voćarstvo u Čačku (Čačanska rodna, Čačanska lepotica, Čačanska najbolja).

Velike štete koje direktno pričinjava, kao i troškovi borbe protiv virusa šarke učinili su da ovaj virus postane jedan od najviše proučavanih biljnih virusa u svetu (Scholthof et al., 2011). U poslednjih 20 godina učinjeni su veliki napori u cilju unapređenja kontrole i upravljanja ovom bolešću. 


\section{PREGLED LITERATURE}

\subsection{Rasprostranjenost virusa šarke šljive}

Virus šarke šljive je prvi put opisan u literaturi 1932. godine kada je bugarski istraživač Atanasoff potvrdio da je prouzrokovač promena na listovima i plodovima šljive virus. Bolesti je dao ime „Шарка по сливитъ“ - Šarka (Sharka), koje se i danas podjednako koristi kao i Plum pox virus. Neki izveštaji govore da su simptomi koje je Atanassoff opisao primećeni oko 1915-1916. godine u Bugarskoj, pa čak i oko 1910. godine na teritoriji Makedonije.

Nakon opisa na šljivi, šarku je Christoff opisao na kajsiji 1933. godine u Bugarskoj (loc cit. Levy et al., 2000a).

U Srbiji je prisustvo šarke najpre primećeno u većem broju zasada šljive istočno od Velike i Južne Morave i u Bregalničkom kraju sredinom 1930.-ih godina (Josifović, 1941). U tom periodu, na teritoriji centralne Srbije šarka je bila samo sporadično prisutna.

Nakon Bugarske i Srbije, šarka šljive je opisana u: Mađarskoj, Rumuniji, Albaniji, Čehoslovačkoj, Nemačkoj, bivšem SSSR-u (Ukrajina i Moldavija), Austriji, Francuskoj, Grčkoj, Holandiji, Švajcarskoj, Turskoj, Velikoj Britaniji i Poljskoj.

Šarka je prvi put opisana na breskvi 1963. godine u Mađarskoj (Németh, 1986).

U periodu od sedamdesetih do devedesetih godina prošlog veka virus šarke je potvrđen i u: Italiji, Belgiji, Španiji, Portugaliji, Danskoj, Norveškoj, Litvaniji i Letoniji.

Osim evropskih zemalja, šarka je otkrivena i u : Egiptu, Siriji, Jordanu, Iranu, Tunisu, Pakistanu i Kazahstanu (Rwahnih et al., 2000; Zamharir et al., 2006; Boulila et al., 2004; Kollerova et al., 2006; Spiegel et al., 2004). Virus šarke je otkriven i na Dalekom istoku: u Indiji (Bhardway, 1995), Kini (Navratil et al., 2005) i nedavno u 
Japanu (Maejima et al., 2010).

$\mathrm{Na}$ teritoriji Američkog kontinenta, šarka je najpre otkrivena u Čileu, a nakon toga u SAD (Levy et al., 2000b), Kanadi (Thompson et. al., 2000) i Argentini (Dall Zotto et al., 2006).

Izolovan geografski položaj, rad karantinske i granične fitosanitarne inspekcije doprineli su da u Australiji i na Novom Zelandu virus šarke šljive nije prisutan (Davis et al., 2002).

Na slici 1 data je šema rasprostranjenosti virusa šarke šljive u svetu.

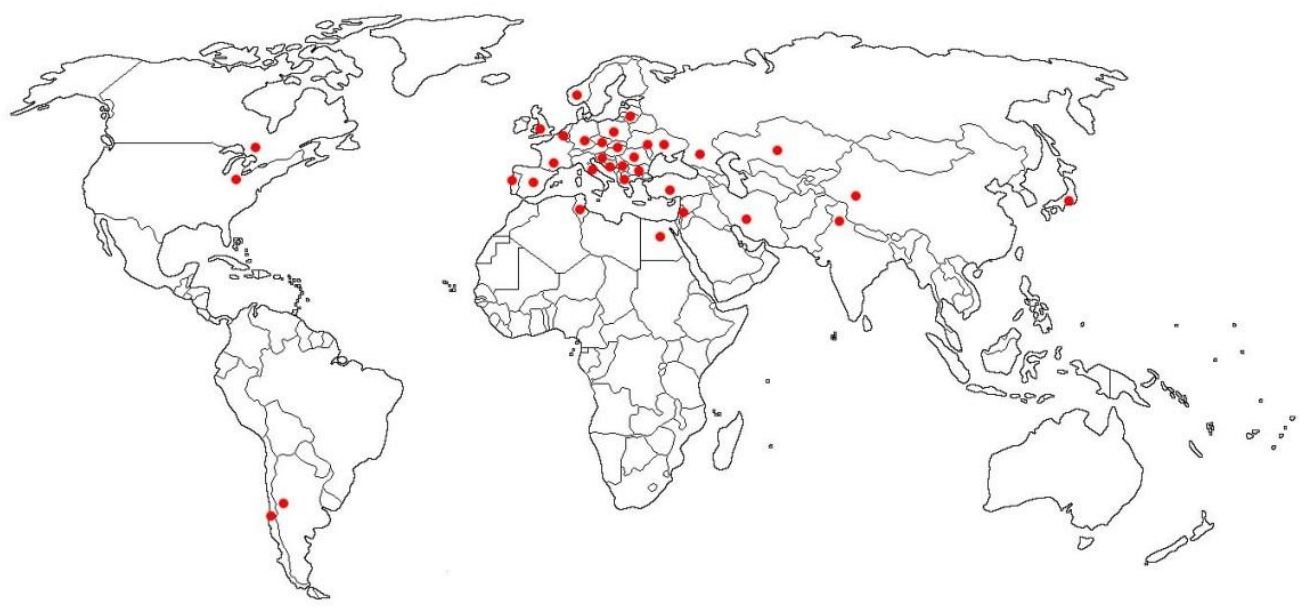

Slika 1. Rasprostranjenost virusa šarke šljive u svetu (označeno •)

Danas je u Srbiji šarka prisutna na celoj teritoriji zemlje (Jevremović, 2008). Od gajenih Prunus vrsta, više decenija je prisutna na šljivi i kajsiji, dok je na breskvi potvrđena tek sredinom osamdesetih godina prošlog veka u blizini granice sa Mađarskom (Dulić i Šarić, 1986).

\subsection{Osobine virusa}

\section{Taksonomija}

Prema važećoj nomenklaturi biljnih virusa, Plum pox virus je član roda Potyvirus, koji sa rodovima Brambyvirus, Bymovirus, Ipomovirus, Macluravirus, Rymovirus, Tritimovirus i jednim neimenovanim rodom (unassigned) čini familiju Potyviridae (Adams et al., 2011). Rod Potyvirus je najbrojniji i ekonomski 
najznačajniji rod fitopatogenih virusa. Virusi iz ovog roda zaražavaju veliki broj biljaka (monokotila i dikotila), prenose se lisnim vašima na neperzistentan način i mogu izazvati ogromne ekonomske štete.

\section{Veličina virusnih čestica}

Čestice virusa šarke šljive su izduženog savitljivog oblika čija dužina varira 660-750 nm, a širina 12,5-20 nm (Slika 2). Najčešća veličina virusnih čestica je 720x18 nm (Ranković, 1974).

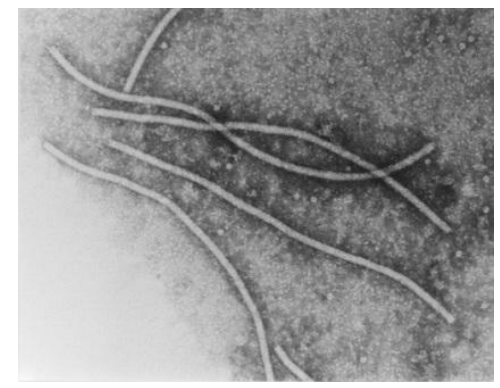

Slika 2. Čestice virusa šarke šljive (foto: ICTV)

\section{Sastav virusnih čestica}

Virusne čestice PPV čini jednolančana infektivna (+)RNK, dužine 9741$9795 \mathrm{~Kb}$, sa 3` poly(A) repom i proteinom povezanim sa genomom (VPg) na 5` kraju. U virusnim česticama, RNK je okružena sa oko 2000 subjedinica proteina omotača.

\section{Biofizička svojstva}

Termalna tačka inaktivacije virusa šarke je $53-58^{\circ} \mathrm{C}$, dok je krajnja tačka razređenja $4 \cdot 10^{-3}$ do $8 \cdot 10^{-3}$ (Ranković, 1974). Postojanost in vitro na $20^{\circ} \mathrm{C}$ je $24-50$ i više časova (Šutić, 1995; Glasa i Candresse, 2005), dok Németh (1986) navodi podatak od 10-80 časova. Obzirom da je virus dobar imunogen, proizvedeni antiserum je visokog kvaliteta i koristi se kod seroloških metoda detekcije (Glasa $i$ Candresse, 2005).

\section{Genom virusa}

Organizacija genoma virusa šarke šljive je tipična za Potyvirus-e. Genom sadrži jedan jedinstveni otvoreni okvir čitanja (ORF) koji se translacijom prevodi u 
jedan veliki poliprotein prekursor $(340-370 \mathrm{kDa})$, a on se post-translaciono viruskodiranim proteazama razlaže na finalne proteine: P1, HC-Pro, P3, 6K1, CI, 6K2, NIa, VPg, NIb i CP (Urcuqui-Inchima et al., 2001; Salvador et al., 2006) (Slika 3).

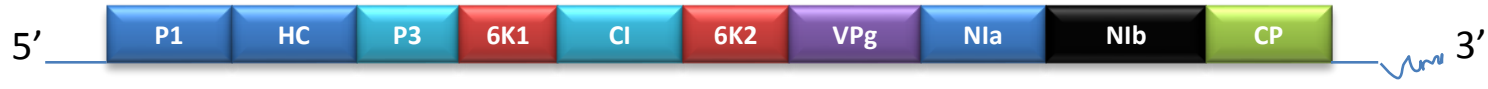

Slika 3. Šematski dijagram genoma virusa šarke šljive

\subsection{Sojevi}

Varijabilnost izolata virusa šarke je davno uočena prilikom njegovog prenošenja na zeljaste i drvenaste indikatore. Schade je još 1969. godine prilikom prenošenja virusa šarke šljive na zeljastu indikator biljku Nicotiana clevelandii Grey uočio da izolati iz južne i srednje Evrope izazivaju različite simptome. Nakon toga, Šutić et al., (1971) opisuju tri tipa simptoma šarke na indikator biljci Chenopodium foetidum Schrad. Oni opisuju žuti, žutonekrotični (intermedijalni) i nekrotični soj. Žuti soj izaziva žute pege koje se sporo razvijaju i ne dovode do opadanja lišća. Žutonekrotični soj izaziva žute pege sa manjom ili većom nekrozom u središtu, a inficirano lišće može kasnije opasti. Kod nekrotičnog soja vrlo brzo se javljaju nekrotične pege, lišće brzo požuti i propada. Ova podela sojeva je bila u upotrebi tokom sedamdesetih godina iako nije uvek bilo lako napraviti jasnu razliku ispoljenih simptoma.

$\mathrm{Na}$ bazi bioloških, seroloških i molekularnih karakteristika do danas je opisano 7 sojeva virusa šarke: PPV-M, PPV-D, PPV-EA, PPV-C, PPV-Rec, PPV-W i PPV-T.

\section{$P P V-M$}

PPV-M (Marcus) soj je izvorno okarakterisan na breskvi poreklom iz Grčke (Kerlan i Dunez, 1979). Ovaj soj je infektivan za breskvu, kajsiju i šljivu. Preovladava u zemljama južne, istočne i centralne Evrope. Aktivno se prenosi lisnim vašima, naročito u zasadima breskve (Dallot et al., 1998). Na bazi molekularnih karakteristika definisane su dve podgrupe PPV-M izolata, nazvane 
Ma i Mb (Dallot et al., 2011). Izolati iz Ma podgrupe su poreklom iz mediteranskih zemalja, dok Mb podgrupi pripadaju izolati iz zemalja centralne i istočne Evrope. Ranije su Myrta et al., (2001) na bazi seroloških osobina ispitivanih izolata izneli pretpostavku o postojanju dve podgrupe M izolata, označene M1 i M2. U to vreme PPV-Rec soj nije bio identifikovan, pa postoji mogućnost da su predstavnici neke od predloženih podgrupa M1 i M2 ustvari PPV-Rec izolati.

\section{$P P V-D$}

PPV-D soj (Dideron) izvorno je izolovan sa kajsije u Francuskoj (Kerlan $i$ Dunez, 1979). Prisutan je u gotovo svuda gde je potvrđeno prisustvo virusa šarke. U literaturi se navodi da je PPV-D soj ne-epidemični soj, za razliku od PPV-M soja. Međutim, ova podela nije striktna jer patogenost sojeva zavisi od više faktora, a jedan od njih je i specifična interakcija izolata, vrste i sorte domaćina. PPV-D soj takođe zaražava breskvu, kajsiju i šljivu.

\section{PPV-EA}

PPV-EA (El Amar) soj su otkrili Wetzel et al., (1991a) prilikom sekvencione analize 3'-terminalnog regiona genoma izolata iz Egipta. Lokalizovan je samo na terioriji Egipta. PPV-EA soj zaražava kajsiju, dok na šljivi i breskvi izaziva blage simptome (Shalabi et al., 2003).

\section{$P P V-C$}

Da i ostale vrste roda Prunus nisu imune na virus šarke potvrdili su Kalashyan et al., (1994) opisom virusa šarke na višnji u Moldaviji. Ubrzo nakon ovog saopštenja, šarka je detektovana na višnji i trešnji u Italiji, Mađarskoj, Bugarskoj i Rumuniji (Topchiiska, 1994; Crescenzi et al., 1995; Nemchinov i Hadidi, 1996; Nemchinov et al., 1998; Crescenzi et al., 1997; Isac i Zagrai, 2006). Kao novi soj pod imenom PPV-C (Cherry), koji zaražava trešnju i višnju, predložili su ga Nemchinov et al., (1996). Iako su prirodni domaćini ovog soja trešnja i višnja, PPV-C izolati se potencijalno mogu preneti i na druge vrste iz roda Prunus (Bodin et al., 2003).

\section{PPV-Rec}

Rekombinantni izolat virusa šarke šljive ǒ6, poreklom iz Srbije, su prvi put 
opisali Cervera et al., (1993). Tek nakon nalaza drugog rekombinantnog izolata BOR-3 u Slovačkoj razvijaju se protokoli za detekciju ovih izolata (Glasa et al., 2001). Kao novi soj koji obuhvata rekombinantne izolate, ustanovljen je PPV-Rec (Recombinant) (Glasa et al., 2004). PPV-Rec izolati predstavljaju prirodne rekombinante PPV-M i PPV-D izolata. Mesto rekombinacije je u C-terminalnom delu NIb gena na poziciji nukleotida 8450. Rekombinantni izolati imaju D-tip genoma PPV, izuzev C-terminalnog dela NIb gena, gena za protein omotača (CP) i 3' nekodirajući region, koji su M-tip (Glasa et al., 2004). Danas su PPV-Rec izolati utvrđeni u: Albaniji, Bugarskoj, Bosni i Hercegovini, Crnoj Gori, Češkoj, Italiji, Kanadi, Nemačkoj, Mađarskoj, Pakistanu, Rumuniji, Slovačkoj, Srbiji i Turskoj (Glasa et al., 2004; Glasa et al., 2005; Myrta et al., 2005; Matić et al., 2006; Isac $i$ Zagrai, 2006; Viršček Marn et al., 2008; Kollerova et al., 2006; Candresse et al., 2007; Thompson et al., 2009). PPV-Rec soj u prirodi zaražava šljivu i kajsiju i efikasno ga prenose lisne vaši. Sve do nalaza Kamenove et al,. (2011) smatralo se da rekombinantni izolati u prirodi ne mogu zaraziti breskvu (Glasa et al., 2002a; 2004; 2005; Jevremović, 2008). Obzirom da protein omotača PPV-Rec i PPV-M izolata ima slične serološke karakteristike, primenom monoklonskih antitela (Mab AL) nije moguće razlikovati ove izolate (Myrta et al., 1998).

\section{$P P V-W$}

$\mathrm{Na}$ bazi seroloških i molekularnih analiza James i Varga (2005) novootkriveni izolat W3174 iz Kanade opisuju kao pripadnika novopredloženog soja PPV-W (Winona). Ovaj soj je nedavno potvrđen i u Rusiji, Ukrajini i Letoniji (Glasa et al., 2011).

\section{$P P V-T$}

Poslednje opisani soj virusa šarke, nazvan PPV-T (Turkey) soj, obuhvata nove rekombinantne izolate koji su opisani samo na teritoriji Turske $\mathrm{u}$ regionu Ankare (Serçe et al., 2009). Ove izolate karakteriše jedinstvena rekombinacija u HCPro genu oko pozicije nukleotida 1566.

Na teritoriji Srbije potvrđeno je prisustvo tri soja virusa šarke šljive: PPV-M, PPV-D i PPV-Rec (Dulić-Marković, 2003; Paunović i Jevremović, 2003; Glasa et al., 2005; Jevremović et al., 2007; Jevremović, 2008; Paunović i Jevremović, 2009). 


\subsection{Simptomi}

Virus šarke na osetljivim sortama izaziva simptome na lišću, plodovima, cvetovima, granama i semenu.

\section{Simptomi na lišću}

Kod osetljivih sorti šljive, prvi simptomi šarke javljaju se na mladim listovima u vidu poluprstenastih i prstenastih pega sa središtem zelene boje, hlorotičnih šara i mozaika (Slika 4). U zavisnosti od sorte, izolata virusa i uslova spoljašnje sredine mogu se javiti i tamne nekrotirane pege i prstenovi. Kod sorte Čačanska rodna se u uslovima sistemične zaraze i izrazito toplih letnjih meseci javlja jako izražena hloroza tako da listovi imaju gotovo žutu boju. U slučajevima mešanih infekcija sa virusom kržljavosti šljive (Prune dwarf virus) i virusom nekrotične prstenaste pegavosti prunusa (Prunus necrotic ringspot virus) mogu se javiti i hlorotične pege i prstenovi oivičeni oreolom ljubičaste boje (Slika 7).

Simptomi na listovima kajsije su slični kao na šljivi, ali se najčešće teže uočavaju (Slika 5) i lokalizovani su na listovima u unutrašnjosti donjih delova krošnje.

$\mathrm{Na}$ listovima breskve virus šarke izaziva karakteristično prosvetljavanje nerava. Nervi zaostaju u porastu što dovodi do deformacije listova i kovrdžavosti. Takođe, kod nekih sorti se primećuju i hlorotični prstenovi, pege i šare. Kod nekih sorti se u uslovima jake zaraze mogu javiti i ljubičaste pege (Slika 6).

Kod osetljivih sorti višnje i trešnje simptomi su u vidu hlorotičnog šarenila i hlorotičnih prstenova. U većini slučajeva, PPV-C soj ne izaziva simptome na lišću.

Listovi badema ne pokazuju simptome ili se izuzetno javlja blaga hloroza (Damsteegt et al., 2007). 

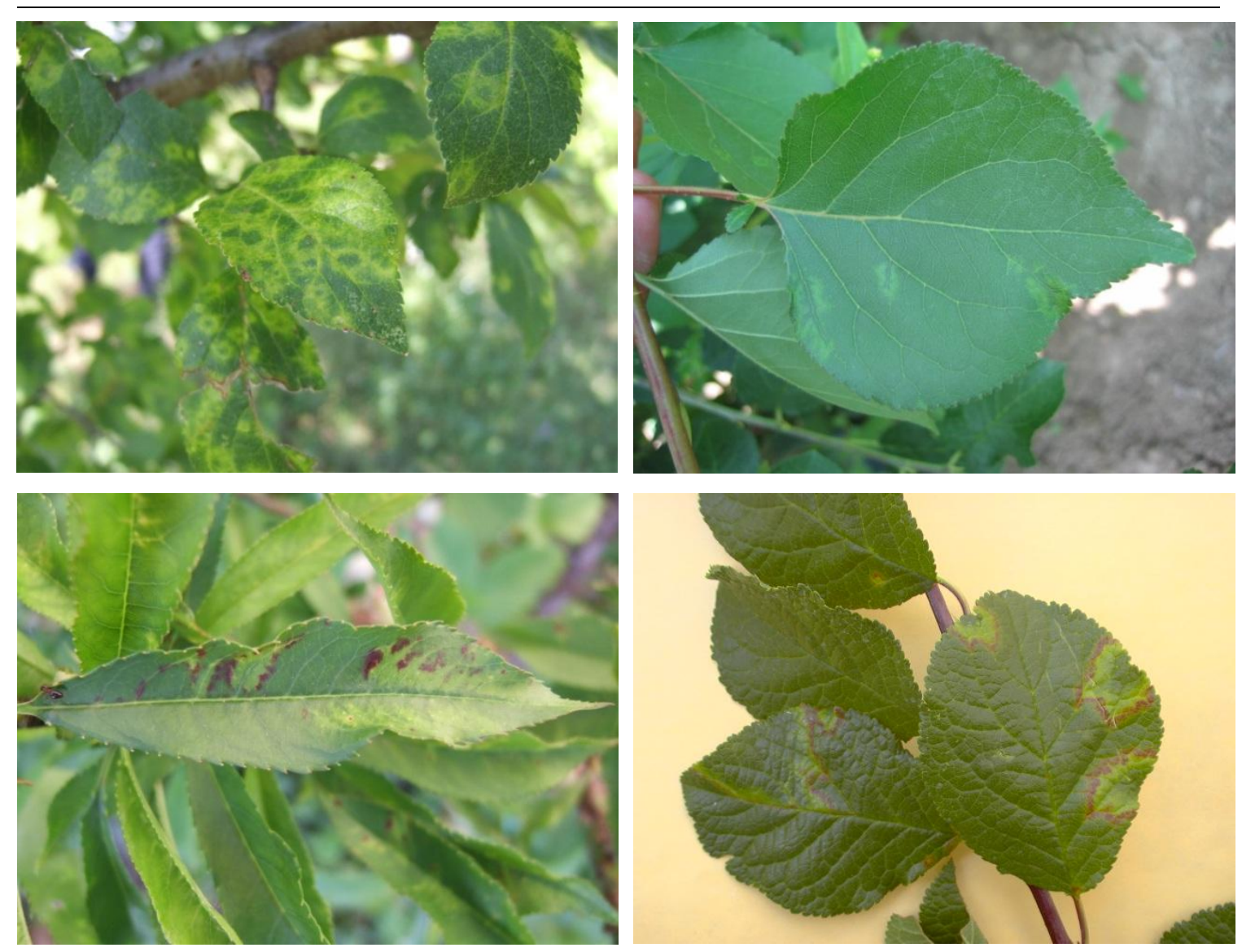

Slike 4-7. Simptomi virusa šarke na listovima šljive, kajsije, breskve i šljive

U literaturi se navodi da su simptomi na listovima koji se razvijaju kasnije tokom vegetacije slabo izraženi ili se gube (Németh, 1986). U našim uslovima, čak i tokom letnjih meseci, ne dolazi do izrazitog povlačenja simptoma na šljivi i oni se uočavaju tokom perioda vegetacije.

\section{Simptomi na plodovima}

Simptomi koje virus šarke izaziva na plodovima osetljivih sorti šljive javljaju se tokom zrenja plodova. Najpre na pokožici plodova dolazi do promene boje i pojave ulegnuća. Na ovim mestima pokožica je za nijansu tamnije boje u odnosu na ostali deo ploda. Sa dozrevanjem, ove promene boje se polako gube. Najveće promene na plodovima javljaju se u mezokarpu. Kod osetljivih sorti, kao što je Požegača, na mestima gde je došlo do promene boje pokožice, javljaju se udubljenja koja se zrenjem sve više diferenciraju (Slika 8). Delovi mezokarpa tamne, nekrotiraju i dolazi do pojave smole. Ovaj deo ploda je usled ovih promena 
znatno tvrđi. Ovakvi plodovi su sitniji, lakši, deformisani i prevremeno opadaju (Slika 11). Kod tolerantnih sorti simptomi su veoma blagi, javljaju se na pojedinačnim plodovima ili ih nema.
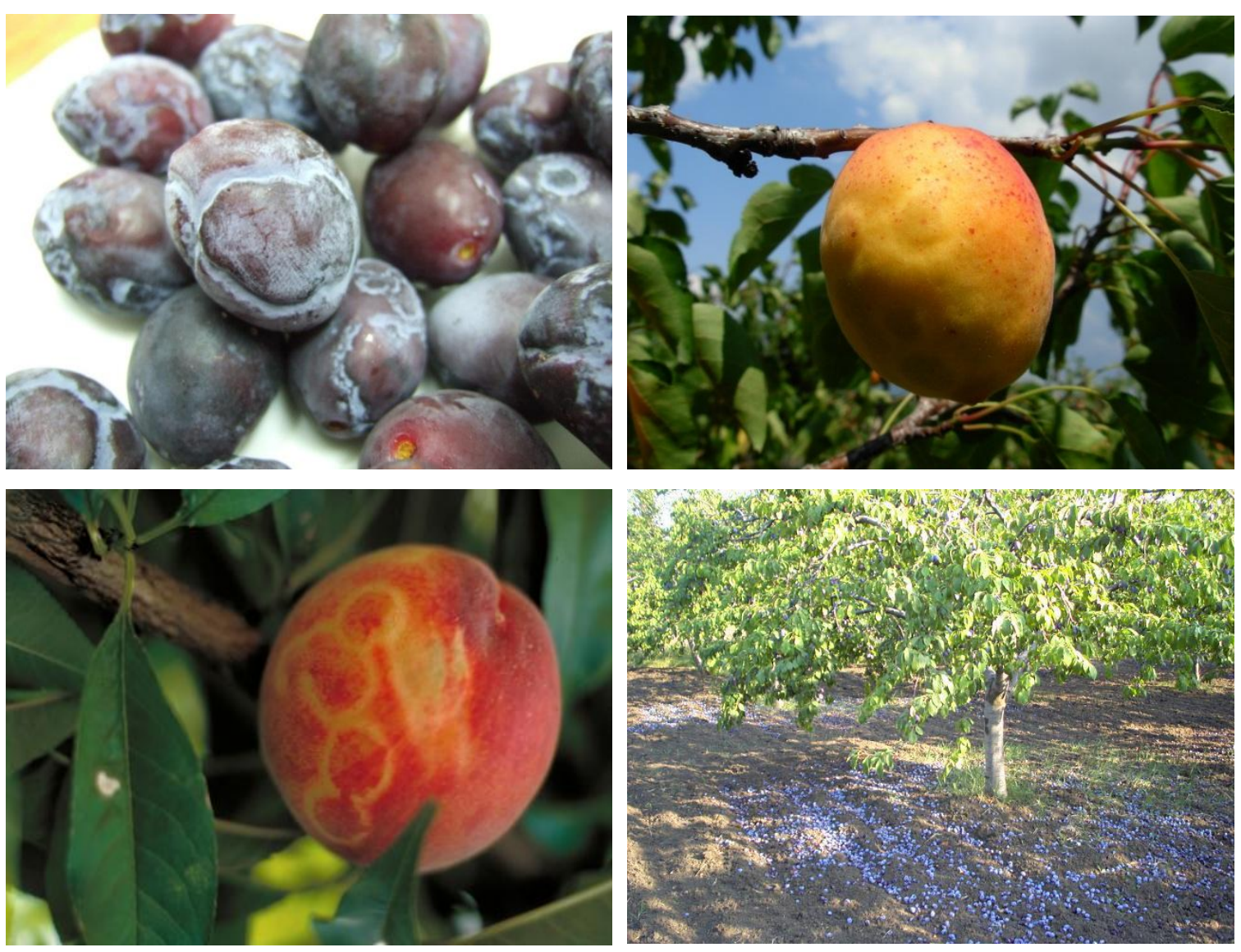

Slike 8-10. Simptomi virusa šarke na plodovima šljive, kajsije i breskve Slika 11. Prevremeno opadanje plodova sa zaraženog stabala šljive (slika 10: EPPO, Francuska)

Kod osetljivih sorti kajsije javljaju se hlorotične pege i prstenovi. Kod nekih sorti ovi prstenovi potamne, tkivo ispod njih nekrotira i plodovi dobijaju deformisan izgled (Slika 9). Ovakvi plodovi su sitniji, lakši i neukusni.

Kod plodova breskve simptomi su, u odnosu na šljivu i kajsiju, blaže izraženi. Kod osetljivih sorti sa belim mezokarpom, simptomi su u vidu bledih i difuznih prstenova, dok kod onih sa žutim mezokarpom javljaju se žuti i crvenkasti prstenovi i pege (Slika 10). U izuzetnim slučajevima javlja se i deformacija plodova.

\section{Simptomi na cvetovima}

Promene na kruničnim listovima izazvane virusom šarke šljive javljaju se 
samo kod osetljivih sorti breskve. Kod sorti sa ljubičastom bojom cvetova dolazi do obezbojavanja u vidu hlorotičnih crta i mozaika (Slika 12) (Desvignes, 1999).

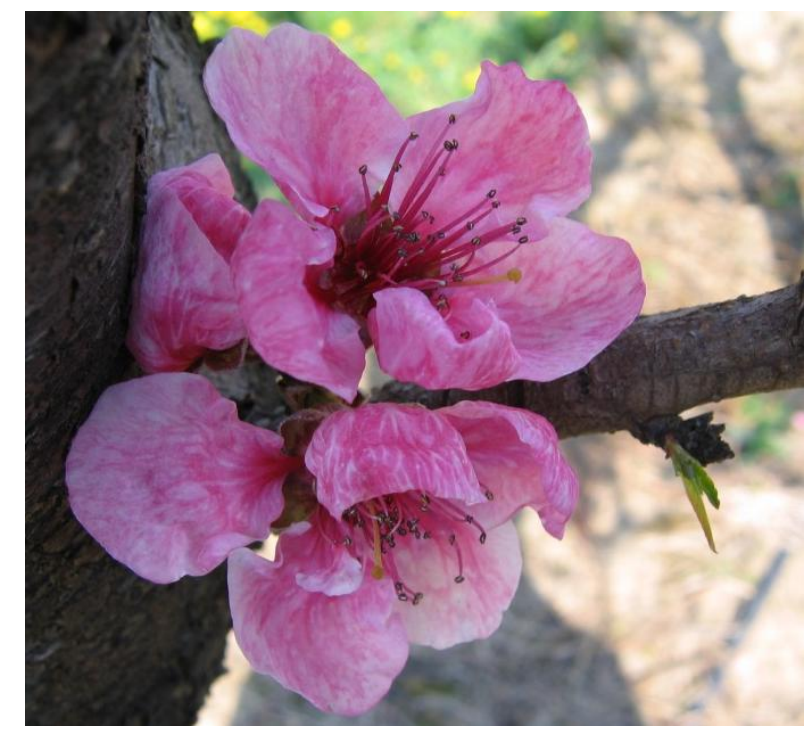

Slika 12. Obezbojavanje kruničnih listova cvetova breskve usled zaraze virusom šarke (prof. dr B. Krstić, Poljoprivredni Fakultet, Beograd)

\section{Simptomi na granama}

Ovaj tip simptoma je u literaturi znatno manje opisan. Neke sorte šljiva (Cambridge Gage, Italian Prune, Kirke's Blue) u slučajevima veštačke inokulacije posle četiri godine pokazuju simptome pucanja kore, sušenja letorasta, ogoljavanja grana i čitavih biljaka (Zawadska et al., 1982; Ranković et al., 1998).

\section{Simptomi na koštici}

Pojava prstenova na koštici kajsije je čest simptom virusa šarke šljive i ima dijagnostički značaj. U zavisnosti od sorte, simptomi u vidu pega i „leopardove kože“ mogu biti jako izraženi (Slika 13). Kod šljive, ovaj tip simptoma je znatno ređa pojava koja je primećena kod nekih starih sorti Uordović i Janda, 1963; Hristov, 1965). Nedavno, Paunović i Jevremović (2002) su opisali simptome prstenaste pegavosti na koštici hibrida šljive 36/114/87 (Slika 14). 

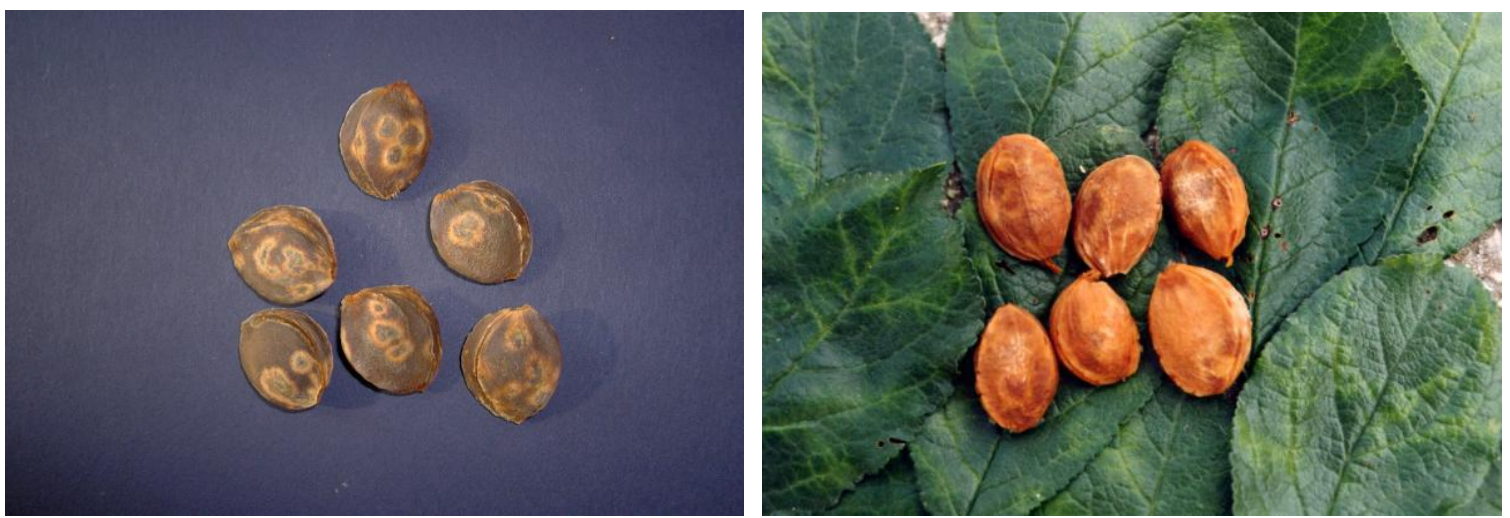

Slike 13 i 14. Simptomi virusa šarke na košticama kajsije i šljive

\subsection{Domaćini}

Virus šarke zaražava veći broj vrsta u okviru roda Prunus. Najznačajniji domaćini obuhvataju gajene vrste: šljivu (Prunus domestica L.), japansku šljivu ( $P$. salicina Lindl.), kajsiju (P. armeniaca L.), breskvu (P. persica (L.) Batsch), nektarinu (P. persica (L.) Batsch var. nucipersica (Suckow) C. K. Schneid), trešnju (P. avium L.), višnju (P. cerasus L.) i badem (P. amygdalus L.).

Zaražene Prunus vrste koje rastu u prirodi, pored puteva i u urbanim sredinama služe kao izvor zaraze. Najzačajnije su: dženarika (P. cerasifera Ehrh.) i crni trn (Prunus spinosa L.). U domaćine virusa šarke spadaju i: P. glandulosa Thunb., P. insititia L., P. americana Marshall, P. besseyi Bailey, P. blieirana L., P. brigantina Vill., P. dasycarpa Ehrh., P. curdica Fenzl ex Fritsch, P. davidiana (Carrière) Franch., P. laurocerasus L., P. holoserica (Batalin) Kostel, P. hortulana L.H. Bailey, P. japonica Thunb., P. mahaleb L., P. mandshurica (Maxim.) Koehne, $P$. maritima Marshall, P. microcarpa C. A. Mey., P. mume Siebold \& Zucc., P. nigra Ait., P. pseudoarmeniaca Heldr. \& Sartori, P. pumila L., P. sibirica L., P. simonii Carr., $P$. tomentosa (Thunb.) Wall., P. triloba Lindl. i neki njihovi međuvrsni hibridi (Németh, 1986; Anonymous, 2004; Kamenova i Milusheva, 2005; Polak, 2006).

Pored vrsta iz roda Prunus, kao domaćini PPV navode se i: hmelj (Humulus lupulus L.), oskoruša (Sorbus domestica L.), kalina (Ligustrum vulgare L.), kurika (Euonymus europaeus L.) i goji (Lycium barbarum L) (Anonymous, 2004; Polak, 2001; Pribek et al., 2001).

Kod zeljastih biljaka opisano je preko 70 vrsta iz 9 familija koje virus šarke 
može zaraziti (Llácer, 2006). Opisane su i neke korovske vrste koje se mogu naći u voćnjacima koje su domaćini PPV, ali se smatra da ove vrste nemaju značajnu ulogu u epidemiologiji virusa šarke (Stobbs et al., 2005; Llácer, 2006).

\subsection{Načini prenošenja virusa}

Osnovni način širenja virusa šarke šljive na veće udaljenosti je putem zaraženog sadnog materijala (sadnice, podloge i kalem-grančice). Na ovaj način zaražene biljke ili njeni delovi dospevaju u novu sredinu, a biljne vaši prenose virus na okolna nezaražena stabla. Razmnožavanje korenovim izdancima, koje je kod nas u prošlosti bilo veoma rašireno, takođe ima značaja u širenju šarke. Požegača i neke autohtone rakijske sorte (Crvena ranka, Metlaš, Trnovača, Crnošljiva) imaju osobinu davanja velikog broja izdanaka i ranije su na ovaj način dominantno razmnožavane.

Virus šarke se u prirodi prenosi lisnim vašima na neperzistentan način. Opisano je oko 20 vrsta lisnih vaši koje u prirodi i eksperimentalno mogu preneti virus šarke: Aphis arbuti Ferr., A. craccivora Koch., A. spiraecola Pag., A. fabae Scop., A. hederae Kalt., A. gossypii Glover, Brachycaudus helichrysi Kalt., B. cardui L., B. persicae Pass., B. schwartzi Börn., Dysaphis plantaginea Pass., D. pyri Boyer de Fons., Hyalopterus pruni Geofrr., Macrosiphum rosae L., Megoura rosae Buck., M. viciae Buck., Metopolophium dirhodum Walk., Myzus persicae Sulz., M. varians David., Phorodon humuli Schr., Rhopalosiphum padi L., Sitobion fragariae Walk., Toxoptera citricida Kirk. i Uroleucon sonchi L (Kunze i Krczal, 1970; Isac et al., 1998; Labonne et al., 1995; Levy et al., 2000a; Manachini et al., 2004; Gildow et al., 2004). Prisutna je široka genetička varijabilnost unutar virusa šarke pa je stepen prenošenja virusa različitim vrstama lisnih vaši zavisna, ne samo od soja virusa, već i od pojedinačnih izolata.

Kao najefikasniji vektori opisane su vrste: B. helicrysi Kalt., B. cardui L., M. persicae Sulz. i P. humuli Schr. (Labone et al., 1995; Kegler i Hartmann, 1998). Velike razlike postoje u efikasnosti prenošenja u različitim zemljama. Tako je vrsta $M$. persicae Sulz. $\mathrm{u}$ visokom procentu prisutna u zasadima mediteranskih zemalja $\mathrm{i}$ efikasan je vektor. Nasuprot tome, na severu Evrope ova vrsta nema značajnu 
vektorsku ulogu zbog samih klimatskih uslova (Blystad et al., 2007). Velika varijabilnost u efikasnosti prenošenja PPV postoji unutar vrste lisnih vaši. Labonne i sar. (1995) opisuju da različiti klonovi vrste A. gossypii Glover prenose virus šarke različitom efikasnošću. Prenošenje Potyvirus-a vektorima uključuje najmanje dva virus-kodirana proteina: protein omotača (CP) i helper komponentu (HC-Pro) (Lopez-Moya et al., 1999; Salvador et al., 2006). Triplet aminokiselina (asparaginska kiselina-alanin-glicin), odnosno asp-ala-gly ili DAG tripeptid, lociran u Nterminalnom delu CP mnogih Potyvirus-a učestvuje u interakciji sa HC-Pro i igra značajnu ulogu u procesu prenošenja virusa (Blanc et al., 1997; Lopez-Moya et al., 1999; Raccah et al., 2001; Dombrovsky et al., 2005). Utvrđeno je da delecije u ovom delu genoma, odnosno nedostatak ovog tripleta, znači i gubitak sposobnosti prenošenja PPV biljnim vašima.

Vertikalna transmisija (prenošenje putem semena) nije prisutna kod virusa šarke šljive. To potvrđuje više saopštenja (Pasquini et al, 2006; Zagrai i Zagrai, 2008). Prenošenje putem polena nije utvrđeno, iako PPV izaziva morfološke i fiziološke promene polena, kao i nepravilnosti u njegovom obrazovanju (loc. cit. Šutić, 1995). Virus se ne prenosi makazama tokom rezidbe, kalemarskim nožem, drugim oruđima tokom obavljanja agrotehničkih mera, kao ni putem zemljišta.

\subsection{Detekcija i karakterizacija}

Od otkrivanja virusa šarke šljive do danas razvijen je veliki broj metoda detekcije i karakterizacije ovog virusa.

\section{Biološki testovi}

Biološki testovi su bazirani na ekspresiji simptoma na osetljivim biljkama indikatorima. U literaturi je opisan veliki broj indikatora PPV, ali je samo mali broj efikasan za biološke testove i uslove gajenja u staklari. U sertifikacionim šemama, biološki test predstavlja pouzdan i praktičan metod za ispitivanje reprodukcionog materijala (Anonymous, 2001). Sa druge strane, zahteva dosta biljnog materijala, radne snage, specifične uslove (staklara, mrežanik) i dugo traje.

Kao indikatori, od zeljastih biljaka su u upotrebi: Chenopodium foetidum 
Schrad., Nicotiana clevelandii Grey, N. benthamiana Domin i Pisum sativum L. (Ranković i Jordović, 1970; Deborre et al., 1995; Gentit, 2006). Zeljaste biljke pokazuju simptome obično 10-15 dana nakon inokulacije. Intenzitet ispoljenih simptoma zavisi od samog soja virusa. Na indikatoru C. foetidum Schrad javljaju se difuzne hlorotične i/ili nekrotične pege. Na N. clevelandii Grey javljaju se hlorotični i nekrotični prstenovi, linije i šarenilo na mladom lišću, a biljke mogu zaostati u porastu i dobiti rozetast izgled.

Od drvenastih indikatora preporučuju se sejanci Prunus persica (L.) Batsch cv. GF305 i P. tomentosa (Thunb.) Wall. Uordović, 1961; Ranković, 1975; Ranković, 1980; Nemeth, 1986: Damsteegt et al., 1997; Anonymous, 2004). Sejanci breskve GF305 su jako pogodni kao indikator jer su osetljivi na veliki broj virusa i virusima slične organizme koji zaražavaju drvenaste voćke. Simptomi se razvijaju nakon 34 nedelje u vidu karakterističnih hlorotičnih linija i prosvetljavanja nerava koje prati deformacija i uvijanje listova. Simptomi su slični kod PPV-M, -D i -EA soja, dok se kod PPV-C soja javljaju veoma bledi simptomi na pojedinim listovima. Istraživanja sprovedena poslednjih nekoliko godina su pokazala da PPV-Rec soj ne izaziva simptome na listovima breskve GF305 ili se javljaju veoma blagi simptomi ograničeni na nekoliko listova koji se vrlo brzo po inokulaciji gube (Glasa et al., 2001; Glasa et al., 2002a; Glasa et al., 2005). Kod inikatora P. tomentosa (Thunb.) Wall. prvi simptomi se javljaju 20-30 dana nakon inokulacije. Tipični simptomi su hloroza duž glavnog lisnog i bočnih nerava. Takođe, mogu se javiti i hlorotične pege koje mogu nekrotirati, deformacije i uvijanje listova, kao i epinastija (Nemeth, 1986).

\section{Serološki testovi (ELISA test)}

Dijagnostika virusa šarke je pojednostavljena razvojem serološkog enzimskog imunoadsorpciog testa (Enzyme Linked Immunosorbent Assay-ELISA). Ova tehnika je prvi put uspešno primenjena pre više od 30 godina (Clark i Adams, 1977). Danas je ELISA rutinska metoda za detekciju virusa šarke koja se primenjuje u mnogim laboratorijama širom sveta, a na tržištu je dostupan veći broj komercijalnih setova i kitova za detekciju. Primenom poliklonskih antitela standardnim DAS-ELISA testom detektuju se svi izolati šarke. Proizvodnjom 
monoklonskih antitela (MAbs) sa serotip-specifičnom reakcijom na PPV-D soj (Mab 4DG5) (Cambra et al., 1994), PPV-M soj (Mab AL) (Boscia et al., 1997), PPV-C (Mab AC i Mab TUV) (Myrta et al., 2000) i PPV-EA soj (Mab EA24) (Myrta et al., 1998), moguće je DASI-ELISA (Double Antibody Sandwich Indirect) testom pored detekcije izvršiti i karakterizaciju sojeva šarke. Ali, sa otkrićem PPV-Rec izolata DASI-ELISA test ne može dati odgovor da li je u ispitivanom uzorku prisutan PPVM ili PPV-Rec soj.

\section{Molekularni testovi}

Razvoj i primena molekularnih metoda za detekciju patogena je značajno promenila dijagnozu i kontrolu biljnih bolesti, uključujući i virus šarke šljive. Potpuna karakterizacija sojeva virusa šarke danas je moguća samo primenom molekularnih metoda. Otkriće lančane reakcije polimeraze (Polymerase Chain Reaction-PCR) dovelo je do značajnog napretka u detekciji i karakterizaciji patogena, pa je ova metoda postala standard u molekularnoj detekciji brojnih patogena.

Nakon izvornog opisa PCR metode, razvijene su njene brojne modifikacije. Jedna od najvažnijih je metoda reverzne transkripcije i lančane reakcije polimeraze (Reverse Transcription PCR - RT-PCR). Virus šarke šljive je jedan od prvih biljnih patogena na kome je primenjena RT-PCR metoda početkom 1990.-ih (Wetzel et al., 1991b). Prvi opisani set prajmera P1-P2 sa ciljnom sekvencom u okviru Cterminalnog regiona gena za protein omotača je danas u širokoj primeni i nalazi se u svim preporučenim protokolima za detekciju PPV.

Uporedo se razvijaju i brojni protokoli za ekstrakciju RNK iz različitog tipa biljnog materijala (listovi, cvetovi, plodovi, kora grančica). Osetljivija tehnika koja je razvijena da se prevaziđe problem inhibitora PCR reakcije i poveća njena osetljivost je Immunocapture RT-PCR (IC-RT-PCR) (Wetzel et al., 1992). IC-RT-PCR je oko 2000 puta osetljivija metoda u odnosu na ELISA test, a oko 25 puta osetljivija u odnosu na RT-PCR metodu.

Nakon toga, su razvijene i druge modifikacije PCR metode sa ciljem povećanja njene osetljivosti i smanjenja mogućnosti kontaminacije: heminestedPCR, PCR-ELISA, nested-PCR u istoj tubici, Print-capture PCR, Co-PCR i Real-time 
RT-PCR (Olmos et al., 1996, 1997, 1999, 2002, 2004; Szemes et al., 2001; Schneider et al., 2004; Mavrodieva i Levy, 2004; Varga i James, 2005).

Za karakterizaciju izolata šarke najpre su korišćeni restrikcioni enzimi. Na bazi nukleotidnih sekvenci 3' regiona genoma virusa šarke i RFLP analize (Restriction Fragment Lenght Polymorphism) sa enzimima RsaI i AluI pokazano je da se izolati šarke mogu grupisati u četiri grupe. PPV-D izolati poseduju RsaI i AluI restrikciona mesta; PPV-M izolati poseduju samo AluI restrikciono mesto; PPV-C izolati nemaju ni RsaI niti AluI restrikciona mesta; dok PPV-El Amar sadrži samo AluI restrikciono mesto. Otkrićem rekombinantnih izolata, primena RFLP analize nije mogla dati odgovor da li se u ispitivanom uzorku radi o PPV-M ili PPV-Rec izolatu.

Pojednostavljenu proceduru za detekciju rekombinantnih izolata baziranu na RT-PCR metodi dali su $\breve{S} u b r$ et al., (2004). Ciljani region je uzvodno i nizvodno oko tačke rekombinacije. Za detekciju se koriste 4 prajmera: mM5, mM3, mD5 i mD3. PPV-D izolate detektuje set mD5-mD3, PPV-M izolate set mM5-mM3, a PPVRec izolate kombinacija prajmera mD5-mM3. Ovaj metod je pogodan ne samo za identifikaciju rekombinantnih izolata, već i mešanih infekcija.

Obzirom da su danas PPV-M, -D i -Rec sojevi najrasprostranjeniji, za pouzdanu detekciju i karakterizaciju primenjuje se protokol koji čine 4 odvojene PCR reakcije. U primeni su PPV-M i PPV-D specifični prajmeri sa ciljnim sekvencama u dva regiona genoma PPV. Prvi, C-terminalni deo NIb i N-terminalni deo CP koji se nalazi nizvodno od tačke rekombinacije; i drugi, lociran u CI regionu uzvodno od tačke rekombinacije.

Za detekciju drugih sojeva PPV (PPV-W i PPV-T) razvijaju se protokoli sa specifičnim prajmerima sa ciljnim sekvencama u različitim regionima genoma PPV. 


\section{CILJEVI ISTRAŽIVANJA}

Osnovni ciljevi istraživanja ove doktorske disertacije vezani su za proučavanje virusa šarke šljive u Srbiji.

Prvi deo istraživanja disertacije ima za cilj redefinisanje statusa rasprostranjenosti sojeva šarke u zasadima šljive i kajsije u različitim regionima gajenja. Ranije sprovedena istraživanja su pokazala da je u zasadima breskve u Srbiji dominantno utvrđen PPV-M soj (Jevremović, 2008), tako da zasadi breskve nisu uključeni u program istraživanja disertacije. Predviđena istraživanja daće detaljan uvid o rasprostranjenosti sojeva šarke u zasadima šljive i kajsije u Srbiji.

Molekularna karakterizacija, sekvencioniranje i filogenetska analiza odabranih izolata virusa šarke omogućiće određivanje stope genetičkog diverziteta izolata iz Srbije, kao i sličnost/različitost srpskih i izolata iz različitih delova sveta. Uključivanjem velikog broja izolata u analizu dobiće se novi podaci i informacije o karakteristikama prisutnih sojeva.

Drugi deo istraživanja sproveden je $u$ eksperimentalnom zasadu šljive kombinovanom primenom seroloških i molekularnih metoda, kao i filogenetske analize primenom odgovarajućih softvera. Cilj istraživanja je utvrđivanje dinamike širenja PPV-Rec i PPV-D izolata virusa šarke iz internih i eksternih izvora infekcije. Sprovedena ispitivanja će ukazati na intenzitet širenja ovih sojeva virusa šarke u novoformiranom zasadu šljive iz izvora infekcije koji se nalazi u samom zasadu, kao i izvora infekcije $\mathrm{u}$ njegovoj neposrednoj blizini. Ispitivanja $\mathrm{u}$ eksperimentalnom zasadu imaju za cilj i određivanje prisustva i brojnosti lisnih vaši tokom perioda vegetacije. Ovim segmentom disertacije dobiće se detaljna slika o prisutnim vrstama lisnih vašiju, kao i o udelu onih vrsta koje su opisane kao 
efikasni vektori virusa šarke. Poznavanje brojnosti i vrsta prisutnih lisnih vašiju značajno je zbog njihove vektorske uloge u prenošenju virusa šarke i planiranja hemijskih mera zaštite.

Osnovni ciljevi istraživanja ove doktorske disertacije su:

- ispitivanje raširenosti sojeva virusa šarke u odabranim zasadima šljive i kajsije, i

- utvrđivanje dinamike širenja PPV-Rec i PPV-D sojeva virusa šarke u otvorenoj kompeticiji u eksperimentalnom zasadu šljive iz internog $\mathrm{i}$ eksternih izvora infekcije.

Rezultati predloženih istraživanja daće nova saznanja o koegzistenciji sojeva virusa šarke u zasadima šljive i kajsije u Srbiji, kao i o karakteristikama širenja i kompeticiji PPV-Rec i PPV-D sojeva u eksperimentalnom zasadu šljive iz internih i eksternih izvora zaraze u početnim godinama. 


\section{MATERIJAL I METODE}

\subsection{Ispitivanje prisustva i karakterizacija izolata virusa šarke iz zasada šljive i kajsije na teritoriji Srbije}

\subsubsection{Biljni materijal}

Biljni materijal za ovo istraživanje sakupljen je u periodu 2008-2010. godine obilaskom velikog broja zasada šljive i kajsije na teritoriji Srbije. Tokom ovog perioda uzimani su uzorci iz sledećih regiona: Jablanički, Kolubarski, Kosovsko-Mitrovački, Mačvanski, Moravički, Nišavski, Pirotski, Rasinski, Šumadijski, Toplički, Zaječarski i Zlatiborski (Slika 15). Ovi regioni predstavljaju najvažnija područja gajenja šljive i kajsije u Srbiji.

Ukupno je sakupljeno 283 uzorka lišća, od toga 263 uzoraka šljive: 261 uzorak domaće šljive (Prunus domestica L.) i 2 uzorka dženarike ( $P$. cerasifera Ehrh.) i 20 uzoraka kajsije (P. armeniaca L.). Uzorci su uzimani tokom juna, jula i avgusta meseca kada su simptomi šarke na listovima jasno izraženi.

Struktura zasada obuhvaćenih ogledom je heterogena i obuhvata: intenzivne, polu-intenzivne, ekstenzivne i zapuštene zasade. Starost stabala $\mathrm{u}$ zasadima je od 3 do preko 60 godina. Iz svakog zasada su slučajnim izborom odabrana u proseku tri stabla sa jasnim simptomima sa kojih su uzimani uzorci lišća. 


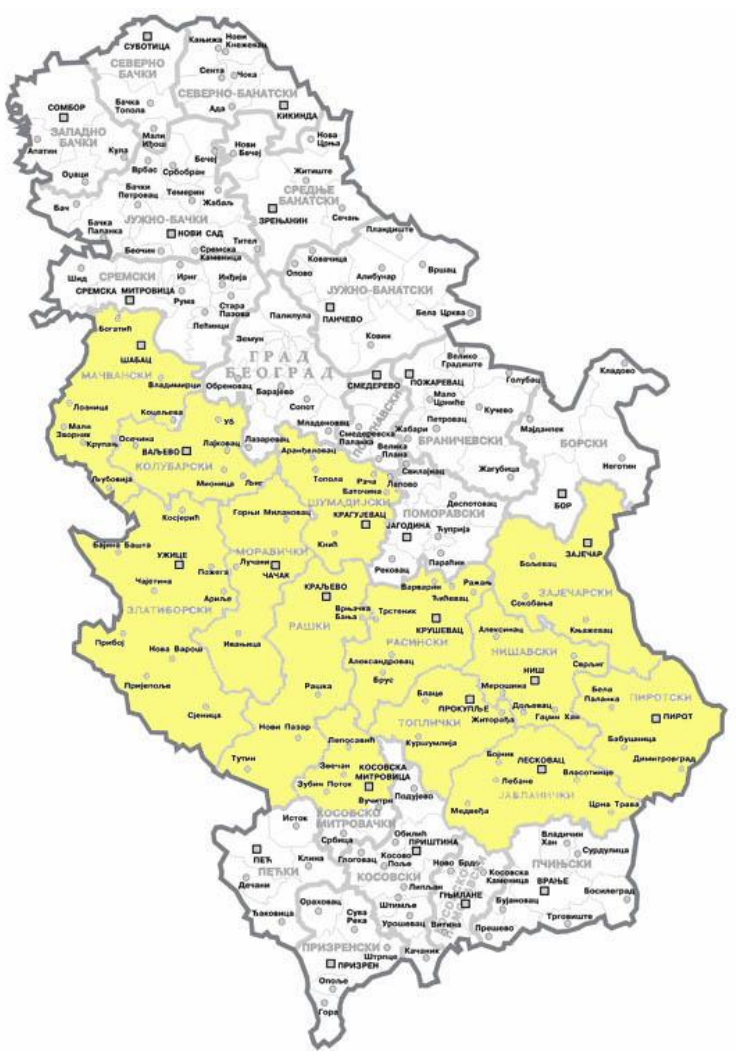

Slika 15. Regioni Srbije iz kojih su uzimani uzorci za analizu na prisustvo PPV (žuto obojeni deo mape)

Svaki uzorak čini 20-25 listova koji su uzeti sa različitih delova krune jednog stabla. Za ispitivanje je korišćen originalni biljni materijal koji je po dolasku u laboratoriju izmeren $(0,5 \mathrm{~g})$ i čuvan u zamrzivaču na $-20^{\circ} \mathrm{C}$.

Kao kontrolni izolati tokom izvođenja molekularnih analiza korišćeni su referentni izolati tri soja PPV: PPV-M, -D i -Rec koji su dobijeni od dr Sylvie Dallot, UMR BGPI, INRA (Monpelje, Francuska).

\subsubsection{Detekcija i tipiziranje izolata virusa šarke}

Detekcija i tipiziranje izolata virusa šarke šljive urađeno je molekularnom IC-RT-PCR metodom. 


\subsubsection{Oblaganje ploča specifičnim antitelima}

Za imunovezivanje poliklonskih antitela (proizvedena $\mathrm{u}$ Institutu za voćarstvo-Čačak) korišćene su polistirenske PCR ploče (Brand GmbH, Nemačka). Za nalivanje jedne ploče napravljeno je razređenje $200 \mu \mathrm{lgG}(0,5 \mathrm{mg} / \mathrm{ml})$ u $10 \mathrm{ml}$ pufera za oblaganje ploča. U svaki otvor ploče naliveno je po $100 \mu$ l pripremljenog razređenja. Obložene ploče su inkubirane u termostatu u trajanju od 150 min na $37^{\circ} \mathrm{C}$.

Nakon inkubiranja, ploče su pipetiranjem isprane dva puta sa autoklaviranim PBS-Tween puferom. Isprana ploča je nalivena pripremljenim uzorcima (4.1.2.2) i pokrivena transparentnom folijom.

\subsubsection{Priprema uzoraka i imunovezivanje virusa (Immunocapture - IC)}

Uzorci su homogenizirani pomoću aparata za homogenizaciju (Matrix, Nemačka) u razređenju 1:10. U kesu za pripremanje uzoraka (Bioreba, Švajcarska) stavljeno je 0,5 g uzorka i $5 \mathrm{ml}$ pufera za ekstrakciju (PBS-Tween + 2\% PVP + 0,45\% Na-DIECA). Do momenta homogenizacije kese sa uzorcima su držane na ledu.

Po homogenizaciji, uzorci su Pasterovim pipetama prebačeni u $1,5 \mathrm{ml}$ plastične tubice (Eppendorf, Nemačka) i centrifugirani 10 min na $4^{\circ} \mathrm{C}$ pri 10000 rpm.

Po centrifugiranju, supernatanti uzoraka su razliveni u prethodno obložene i isprane polistirenske ploče i inkubirani preko noći $(16-18 \mathrm{~h})$ na $4^{\circ} \mathrm{C}$.

Po završenom inkubiranju, ploče su pipetiranjem isprane dva puta sa autoklaviranim PBS-Tween puferom i jednom sa autoklaviranom destilovanom vodom $\left(\mathrm{sdH}_{2} \mathrm{O}\right)$. Sva ispiranja su urađena na ledu.

Isprana ploča je ostavljena $\mathrm{u}$ frižideru na $4^{\circ} \mathrm{C}$ do sprovođenja reverzne transkripcije. 


\subsubsection{Reverzna transkripcija (Reverse Transcription - RT)}

Reverzna transkripcija se sastojala od koraka denaturacije, komplementarnog vezivanja prajmera, same reverzne transkripcije komplementarne DNK (cDNK) prema templetu virusne RNK.

U svaki otvor PCR ploče, koji predstavlja jedan uzorak, dodato je $24,2 \mu \mathrm{l}$ sledećeg miksa:

\begin{tabular}{lr}
\hline TritonX 100 (Serva, Nemačka) & $6 \mu \mathrm{l}$ \\
$\operatorname{pd}\left(\mathrm{N}_{6} 0,5 \mu \mathrm{g} / \mu \mathrm{l}(\right.$ GE Healthcare, Velika Britanija $)$ & $2 \mu \mathrm{l}$ \\
$\mathrm{sdH}_{2} \mathrm{O}$ & $16,2 \mu \mathrm{l}$ \\
\hline
\end{tabular}

Denaturacija je izvedena na $70^{\circ} \mathrm{C}$ u trajanju od $5 \mathrm{~min}$.

Po završenoj denaturaciji u svaki otvor ploče dodato je $25,8 \mu \mathrm{l}$ pripremljenog RT miksa:

\begin{tabular}{|lr}
\hline AMV RT 5X buffer & $10 \mu \mathrm{l}$ \\
dNTPs 2,5 mM & $5 \mu \mathrm{l}$ \\
RNase inhibitor 40u/ $\mu$ l (USB corporation, SAD) & $0.8 \mu \mathrm{l}$ \\
sdH $_{2} \mathrm{O}$ & $9 \mu \mathrm{l}$ \\
$\mathrm{AMV}^{\mathrm{AM}}$ Reverse Transcriptase $10 \mathrm{u} / \mu \mathrm{l}($ USB corporation, SAD) & $1 \mu \mathrm{l}$ \\
\hline
\end{tabular}

Reverzna transkripcija odvijala se na temperaturi od $37^{\circ} \mathrm{C}$ tokom $60 \mathrm{~min}$, a zatim 5 min na $95^{\circ} \mathrm{C}$.

Dobijena komplementarna DNK (cDNK) čuvana je na $-20^{\circ} \mathrm{C}$.

\subsubsection{Lančana reakcija polimeraze (Polymerase Chain Reaction -PCR)}

Za određivanje soja sakupljenih PPV izolata sprovedene su 4 odvojene PCR reakcije sa dva seta PPV-M i PPV-D specifičnih prajmera. Ciljne sekvence ova dva seta prajmera su locirane u delovima genoma virusa uzvodno i nizvodno od tačke rekombinacije (Slika 16). U PCR reakciji ciljana su dva regiona genoma PPV. Prvi, lociran u C-terminalnom delu NIb i N-terminalnom delu za CP; i drugi lociran u CI regionu. 
Za umnožavanje fragmenta od 467 bp lociranog u C-terminalnom delu NIb i N-terminalnom delu za CP primenjen je set prajmera P4-P3D i P4-P3M (Candresse et al., 1998). Karakteristike prajmera korišćenih u ovoj reakciji date su u tabeli 1.

Tabela 1. Karakteristike prajmera korišćenih za umnožavanje fragmenata lociranih u $C$ terminalnom delu NIb i N-terminalnom delu za CP

\begin{tabular}{cccc}
\hline Prajmer & Smer & \multicolumn{1}{c}{ Sekvenca 5'-3' } & Pozicija $^{\mathbf{3}}$ \\
P4 & -1 & TGCCTTCAAACGTGGCACTG & $8893-8912$ \\
P3M & +2 & ACATAGCAGAGACGGCACTC & $8446-8465$ \\
P3D & + & ACATTGCGGAGACAGCACTG & $8446-8465$ \\
\hline 1 Nizvodni prajmer (downstream) & \\
2 Uzvodni prajmer (upstream) \\
3 Pozicija prema izolatu PS (GenBank AJ243957)
\end{tabular}

PCR miks zapremine $25 \mu$ l sadržao je: 2,5 $\mu$ l 10X PCR buffer, 2,5 $\mu \mathrm{l}$ 2,5 mM dNTPs, $2 \mu \mathrm{l} 25 \mathrm{mM} \mathrm{MgCl}_{2}, 15,75 \mu \mathrm{l} \mathrm{sdH}_{2} \mathrm{O}, 0,25 \mu$ lllustra ${ }^{\mathrm{TM}}$ rTaq DNA Polymerase (GE Healthcare, Velika Britanija), po 0,25 $\mu \mathrm{l} 10 \mathrm{mM}$ oba prajmera i $2 \mu \mathrm{l}$ cDNK.

PCR se odigravala po sledećem programu: početna denaturacija na $94^{\circ} \mathrm{C} 5$ min; 35 ciklusa koje čine denaturacija na $92^{\circ} \mathrm{C} 20$ s, vezivanje prajmera na $55^{\circ} \mathrm{C} 20$ s i elongacija prajmera na $72^{\circ} \mathrm{C} 40 \mathrm{~s}$; i finalna elongacija na $72^{\circ} \mathrm{C} 10 \mathrm{~min}$.

Za umnožavanje fragmenata lociranih u delu genoma za cilindrične inkluzije (CI) korišćeni su prajmeri CIP-M/CIP-MR i CIP-D/CIP-DR koji su dizajnirani tokom izrade ove disertacije. Set prajmera CIP-M/CIP-MR amplifikuje fragment od 880 bp, a set CIP-D/CIP-DR fragment od 468 bp. Ovi prajmeri su osetljiviji u odnosu na ranije saopštene setove prajmera CIf-CID i CIf-CIM (Glasa et al., 2002a).

Reakcioni PCR miks zapremine $25 \mu$ l sadržao je: 2,5 $\mu$ l 10X PCR buffer, 2,5 $\mu \mathrm{l}$

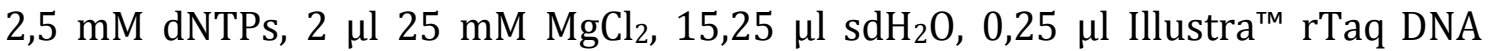
Polymerase (GE Healthcare, Velika Britanija), po 0,25 $\mu 10 \mathrm{mM}$ oba prajmera i $2 \mu \mathrm{l}$ cDNK.

Ova PCR reakcija se odigravala po sledećem programu: početna denaturacija na $94^{\circ} \mathrm{C} 5 \mathrm{~min} ; 35$ ciklusa koje čine denaturacija na $92^{\circ} \mathrm{C} 20 \mathrm{~s}$, vezivanje prajmera na $57^{\circ} \mathrm{C} 20 \mathrm{~s}$ i elongacija prajmera na $72^{\circ} \mathrm{C} 45 \mathrm{~s}$; i finalna elongacija na $72^{\circ} \mathrm{C} 10 \mathrm{~min}$. Karakteristike prajmera korišćenih u ovim reakcijama date su u tabeli 2. 
Tabela 2. Karakteristike prajmera korišćenih za umnožavanje fragmenata lociranih u CI regionu

\begin{tabular}{cccc}
\hline Prajmer & Smer & Sekvenca 5'-3' & Pozicija \\
CIP-M & + & GTCGCAGCATTTGTAGCCCTTGTT & $3528-3551$ \\
CIP-MR & - & CCAACAGCTTAACGCCATGCTTCA & $4384-4407$ \\
CIP-D & + & ATGATGCTGTTTGACTCGGAGCGA & $3552-3575$ \\
CIP-DR & - & TCGCAACTGCTTGCACACATTCTC & $3996-4019$ \\
\hline
\end{tabular}

U slučajevima mešanih infekcija, gde nije bilo moguće potpuno radvojiti prisutne sojeve u jednom uzorku (pozitivan rezultat u sve 4 sprovedene PCR reakcije), primenjeni su prajmeri koji amplifikuju kratke fragmente oko mesta rekombinacije (Tabela 3) (Šubr et al., 2004). Kombinacijom prajmera mM5, mM3, mD5 i mD3 moguće je diferencirati prisutne sojeve.

Tabela 3. Karakteristike prajmera korišćenih za umnožavanje fragmenata lociranih oko mesta rekombinacije

\begin{tabular}{cccc}
\hline Prajmer & Smer & Sekvenca 5' & -3' \\
mM5 & + & GCTACAAAGAACTGCTGAGAG & Pozicija \\
mM3 & - & CATTTCCATAAACTCCAAAAGAC & $8786-8300$ \\
mD5 & + & TATGTCACATAAAGGCGTTCTC & $8207-8228$ \\
mD3 & - & GACGTCCCTGTCTCTGTTTG & $8851-8870$ \\
\hline
\end{tabular}

Reakcioni PCR miks zapremine $25 \mu$ l sadržao je: 2,5 $\mu$ l 10X PCR buffer, 2,5 $\mu \mathrm{l}$ 2,5 mM dNTPs, $1,5 \mu \mathrm{l} 25 \mathrm{mM} \mathrm{MgCl}_{2}, 15,75 \mu \mathrm{sdH}_{2} \mathrm{O}, 0,25 \mu \mathrm{l}$ Illustra ${ }^{\mathrm{TM}}$ rTaq DNA Polymerase (GE Healthcare, Velika Britanija), po 0,25 $\mu \mathrm{l} 10 \mathrm{mM}$ oba prajmera i $2 \mu \mathrm{l}$ cDNK.

Ova PCR reakcija se odigravala po sledećem programu: početna denaturacija na $94^{\circ} \mathrm{C} 3 \mathrm{~min} ; 35$ ciklusa koje čine denaturacija na $94^{\circ} \mathrm{C} 45 \mathrm{~s}$, vezivanje prajmera na $60^{\circ} \mathrm{C} 30 \mathrm{~s}$ i elongacija prajmera na $72^{\circ} \mathrm{C} 60 \mathrm{~s}$; i finalna elongacija na $72^{\circ} \mathrm{C} 7 \mathrm{~min}$.

Sve PCR reakcije su urađene $\mathrm{u}$ termosajkleru Biometra Tpersonal (Whatman Biometra, Nemačka). 


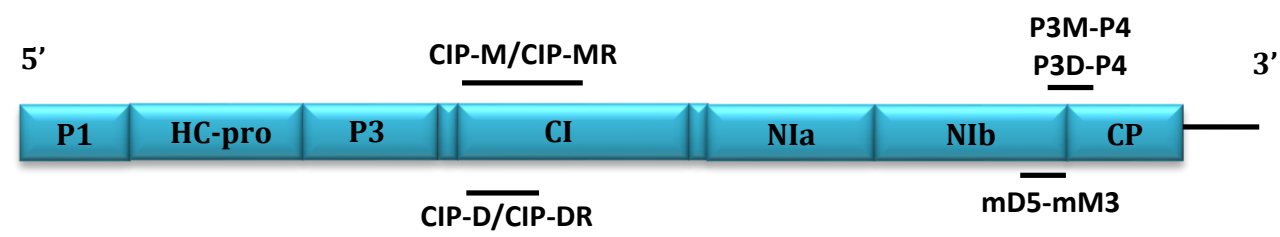

Slika 16. Mapa genoma PPV sa pozicijama fragmenata umnožavanih u PCR reakcijama

\subsubsection{Analiza PCR proizvoda}

Analiza PCR proizvoda urađena je elektroforezom u 1,5\% agaroznom gelu i 0,5X TBE puferu. Agarozni gel je pripremljen rastvaranjem odgovarajuće količine agaroze (USB corporation, $S A D$ ) u 0,5X TBE puferu i zagrevanjem do ključanja. Nakon kratkog hlađenja, gel je razliven u kalup horizontalnog aparata za elektroforezu (Hoefer, SAD). U gel je uronjen češalj postavljanjem u odgovarajuća ležišta kalupa.

Po očvršćivanju gela, češalj je izvađen i kalup sa gelom je postavljen u aparat za elektroforezu u koji je prethodno naliven 0,5X TBE pufer.

U svaki od bunarčića gela naliveno je po $5 \mu \mathrm{l}$ (1/5 vol.) PCR proizvoda. Pre nanošenja u gel, uzorci su pomešani sa $\approx 1 \mu \mathrm{l}$ pufera za nalivanje uzoraka 10X DNA Gel Loading buffer (5Prime, Nemačka). Pri svakoj elektroforezi korišćen je marker Amersham 100 Base-Pair Ladder (GE Healthcare, Velika Britanija).

Elektroforeza se odigravala pri naponu od $130 \mathrm{~V}$ tokom 50 minuta. Bojenje je urađeno potapanjem agaroznog gela u rastvor etidijum-bromida u trajanju od 10-20 minuta. Amplifikovani fragmenti u gelu su posmatrani pod UV svetlošću na transiluminatoru (Hoefer, SAD) i fotografisani aparatom Fuji finepix E900 (Fuji, Japan).

Prisustvo fragmenta odgovarajuće veličine smatrano je za pozitivnu reakciju. 


\subsubsection{Sekvencioniranje delova genoma odabranih izolata}

Za dalju analizu, sa različitih domaćina i iz različitih regiona Srbije odabran je 41 izolat za sekvencioniranje dva različita regiona genoma PPV: C-ter NIb-N-ter CP i C-ter P3-6K1-N-ter CI (slika 17).

Za potrebe sekvencioniranja $\mathrm{C}$-ter $\mathrm{NIb}-\mathrm{N}$-ter $\mathrm{CP}$ regiona sprovedena je PCR reakcija sa setovima prajmera P4-P3D i P4-P3M (Candresse et al., 1998). Kod prethodno okarakterisanih PPV-D izolata primenjen je set prajmera P4-P3D, a kod PPV-Rec izolata primenjen je set prajmera P4-P3M.

Uslovi pod kojima su sprovođene PCR reakcije date su u poglavlju 4.1.2.4. Lančana reakcija polimeraze (Polymerase Chain Reaction -PCR).

Za sekvencioniranje fragmenta lociranog u P3-6K1 (C-ter P3, 6K1 i N-ter CI) regionu genoma, korišćeni su prajmeri PCI-PP3 koji umnožavaju fragment od 836 bp (Glasa et al., 2002b) (Tabela 4).

Tabela 4. Karakteristike prajmera korišćenih za umnožavanje fragmenta lociranog u P3-6K1 regionu

\begin{tabular}{cccc}
\hline Prajmer & Smer & Sekvenca 5'-3' & Pozicija \\
PP3 & + & TTATCTCCAGGARTTGGAGC & 2915-2934 \\
PCI & - & TTGAGTCAAATGGRACAGTTGG & $3729-3750$ \\
\hline
\end{tabular}

Reakcioni PCR miks zapremine $25 \mu$ l sadržao je 2,5 $\mu$ l 10X PCR buffer, $2,5 \mu \mathrm{l}$ 2,5 mM dNTPs, $2 \mu \mathrm{l} 25$ mM $\mathrm{MgCl}_{2}, 14,75 \mu \mathrm{sdH}_{2} \mathrm{O}, 0,25 \mu \mathrm{l}$ Illustra $^{\text {TM }}$ rTaq DNA $^{\text {Th }}$ Polymerase (GE Healthcare, Velika Britanija), po 0,5 $\mu \mathrm{l} 10 \mathrm{mM}$ oba prajmera i $2 \mu \mathrm{l}$ cDNK.

Uslovi pod kojima se odigravala PCR reakcija bili su sledeći: početna denaturacija $94^{\circ} \mathrm{C} 5 \mathrm{~min} ; 35$ ciklusa: $94^{\circ} \mathrm{C} 60 \mathrm{~s}, 50^{\circ} \mathrm{C} 60 \mathrm{~s}$ i $72^{\circ} \mathrm{C} 60 \mathrm{~s}$; i finalna elongacija na $72^{\circ} \mathrm{C} 10 \mathrm{~min}$.

Nakon završetka reakcije, PCR proizvodi su prebačeni u predhodno obeležene 1,5 ml tubice i poslati na sekvencioniranje. 
Prečišćavanje i sekvencioniranje amplifikovanih fragmenata urađeno je $u$ firmi MACROGEN, Seul, Južna Koreja.

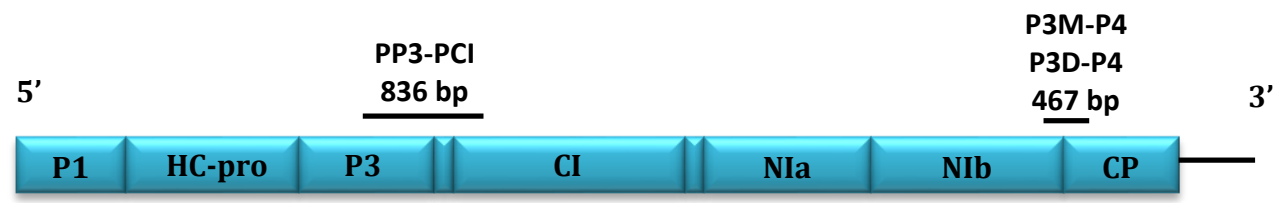

Slika 17. Mapa genoma PPV sa pozicijama različitih fragmenata umnožavanih tokom PCR reakcija u cilju sekvencioniranja

\subsubsection{Filogenetska analiza}

Filogenetska analiza, odnosno proučavanje evolutivne povezanosti odabranih izolata virusa šarke, urađena je na osnovu dobijenih rezultata sekvencioniranja primenom kompjuterskih programa. Ovom analizom projektuje se filogenetsko stablo koje ukazuje na evolutivnu povezanost izolata za koje se veruje da imaju istog zajedničkog pretka, tzv. ancestor. Softveri rekonstruišu filogenetsko stablo na osnovu unetih sekvenci i zadatih parametara upoređivanja.

Sekvence koje su dobijene od firme MACROGEN su obrađene u programu Bioedit sequence alignment editor (verzija 7.0.5.3) (Hall, 1999). Nakon obrade, ove sekvence su upoređene sa sekvencama drugih izolata koje su preuzete iz međunarodnih on-line baza podataka: Nacionalni Centar za Biotehnološke Informacije (NCBI-National Center for Biotechnology Information, SAD: http://www.ncbi.nlm.nih.gov/) i web sajta projekta SharCo (FP7 project - Sharka containment in view of EU-expansion: http://w3.pierroton.inra.fr:8060/users/login).

Za višestruko upoređivanje nukleotidnih sekvenci, proračunavanje genetičke udaljenosti (Neighbor Joining [NJ] metod primenom modela Kimura 2parametra) i filogenetsku rekonstrukciju primenjen je program MEGA5 (verzija 5.05) (Thompson et al., 1994; Kimura, 1980; Tamura et al., 2011).

Za proveru pouzdanosti rekonstruisanog filogenetskog stabla sproveden je bootstrap test sa 1000 ponavljanja (Nei i Kumar, 2000; Salemi i Vandame, 2003). 
Za proučavanje genealoške (rodoslovne) povezanosti izolata primenjen je program TCS (verzija 1.21), po metodi statističke parsimonije (statistical parsimony) za rekonstruisanje istorijske povezanosti sekvenci (Clement et al., 2000; Templeton et al., 1992).

Sekvence dobijene tokom izrade ovog rada unete su u on-line bazu web sajta projekta SharCo. 


\subsection{Ispitivanje dinamike širenja sojeva šarke šljive, prisustva i brojnosti lisnih vaši u eksperimentalnom zasadu šljive}

\subsubsection{Eksperimentalni zasad}

Eksperimentalni zasad za sprovedeno istraživanje podignut je na lokalitetu Ostra u blizini Čačka (GPS koordinate: 435'ㄴ.56"N, 20³0'07.31"E) (Slika 18). Zasad šljive sorte Čačanska lepotica podignut je u proleće 2008. godine, a sastoji se od 400 stabala posađenih na rastojanju $4 \times 3,5 \mathrm{~m}$. Po prijemu sadnica, sve biljke su serološkim DAS-ELISA testom ispitane na prisustvo virusa šarke radi provere zdravstvene ispravnosti sadnica.

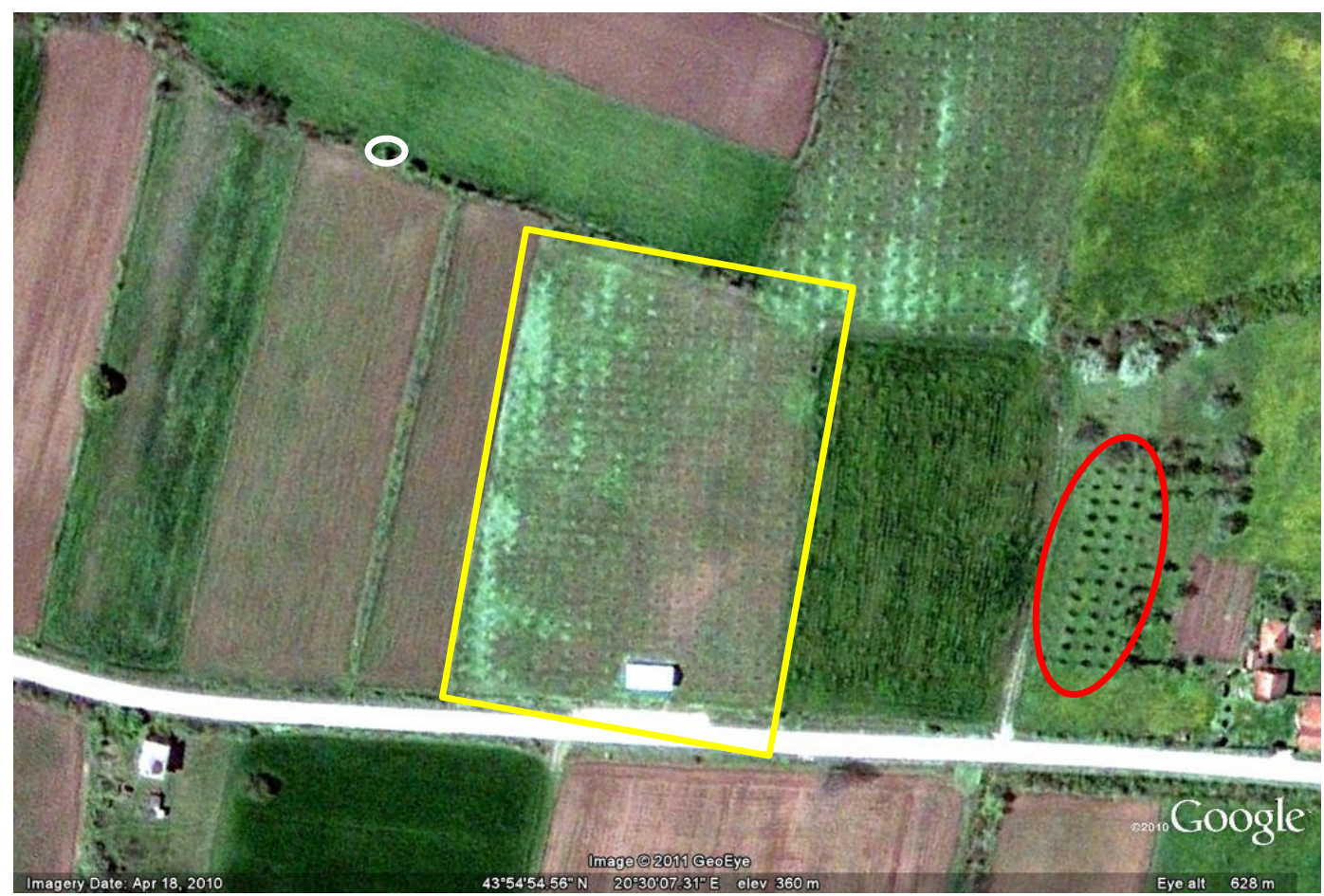

Slika 18. Eksperimentalni zasad šljive (označeno žutom linijom) Mali zasad šljive sorte Stenley (označeno crvenom linijom) Stabla šljive sorte Crvena ranka (označena belom linijom)

U junu 2008. godine izvršena je inokulacija 8 biljaka šljive sa prethodno okarakterisanim i sekvencioniranim PPV-D i PPV-Rec izolatima RS-68pl i RS-67pl. 
Sekvencioniranje kompletnog genoma navedenih izolata urađeno je u INRA Institutu u Monpeljeu (Dallot et al., neobjavljeni podaci). PPV-D izolat (RS-68pl) je poreklom sa hibrida šljive 36/114/87 (lokalitet: Čačak, godina izolacije: 2007.), a PPV-Rec izolat (RS-67pl) je poreklom sa šljive sorte Čačanska rodna (lokalitet: Gornja Gorevnica, godina izolacije: 2007.).

\begin{tabular}{|c|c|c|c|c|c|c|c|c|c|c|c|c|c|c|c|c|}
\hline 29 & & & & $\circ$ & 0 & ० & ० & 0 & $\circ$ & & & & & & & \\
\hline 28 & & & & 0 & 0 & 0 & 0 & 0 & 0 & ○ & 0 & $\circ$ & & & & \\
\hline 27 & & & & 0 & 0 & ○ & o & o & ० & ○ & 0 & 0 & ० & 0 & 0 & o \\
\hline 26 & & & & 0 & 0 & 0 & ० & ○ & 0 & 0 & 0 & 0 & 0 & 0 & $\circ$ & o \\
\hline 25 & & & & O & ० & 0 & o & o & o & ० & 0 & ० & 0 & 0 & o & o \\
\hline 24 & & & ० & 0 & ० & 0 & o & o & 0 & 0 & 0 & 0 & 0 & 0 & o & ○ \\
\hline 23 & & & 0 & ० & 0 & 0 & o & o & 0 & 0 & 0 & 0 & 0 & 0 & O & o \\
\hline 22 & & & $\circ$ & 0 & 0 & 0 & o & o & 0 & 0 & 0 & 0 & 0 & 0 & o & O \\
\hline 21 & & & 0 & 0 & 0 & 0 & 0 & o & 0 & 0 & 0 & 0 & 0 & 0 & $\circ$ & ० \\
\hline 20 & & & 0 & 0 & 0 & 0 & 0 & o & 0 & 0 & 0 & 0 & 0 & 0 & $\circ$ & ० \\
\hline 19 & & & ० & 0 & 0 & 0 & o & o & 0 & 0 & 0 & 0 & 0 & 0 & o & o \\
\hline 18 & & & 0 & $\circ$ & O & $\circ$ & ० & $\circ$ & 0 & 0 & 0 & 0 & 0 & 0 & 0 & 0 \\
\hline 17 & & & $\circ$ & 0 & 0 & 0 & o & 0 & 0 & 0 & 0 & 0 & 0 & 0 & $\circ$ & o \\
\hline 16 & & & $\circ$ & ○ & 0 & $\circ$ & ० & 0 & • & $\bullet$ & 0 & ० & ० & o & o & ○ \\
\hline 15 & & & 0 & ० & 0 & 0 & o & o & $\bullet$ & • & 0 & 0 & 0 & 0 & o & o \\
\hline 14 & & & 0 & 0 & 0 & $\circ$ & 0 & 0 & • & $\bullet$ & 0 & 0 & 0 & $\circ$ & $\circ$ & o \\
\hline 13 & & & ० & ० & 0 & 0 & o & 0 & $\bullet$ & $\bullet$ & o & 0 & 0 & 0 & O & ○ \\
\hline 12 & & 0 & ० & 0 & O & 0 & o & 0 & 0 & 0 & 0 & 0 & 0 & 0 & o & O \\
\hline 11 & & o & o & $\circ$ & 0 & 0 & $\circ$ & $\circ$ & 0 & 0 & 0 & 0 & 0 & o & $\circ$ & 0 \\
\hline 10 & & 0 & 0 & ० & 0 & 0 & 0 & 0 & 0 & ० & 0 & ० & 0 & 0 & o & ० \\
\hline 9 & & 0 & 0 & 0 & 0 & 0 & o & o & 0 & 0 & 0 & 0 & 0 & 0 & o & 0 \\
\hline 8 & & 0 & 0 & 0 & 0 & 0 & o & 0 & 0 & 0 & 0 & 0 & 0 & 0 & ० & o \\
\hline 7 & & O & 0 & 0 & 0 & 0 & 0 & 0 & $\circ$ & 0 & 0 & O & 0 & o & o & 0 \\
\hline 6 & & $\circ$ & 0 & 0 & 0 & $\circ$ & o & 0 & 0 & $\circ$ & 0 & 0 & 0 & 0 & o & o \\
\hline 5 & & 0 & 0 & $\circ$ & 0 & 0 & o & 0 & 0 & 0 & 0 & 0 & 0 & 0 & o & o \\
\hline 4 & & ० & 0 & 0 & 0 & 0 & o & 0 & 0 & 0 & 0 & 0 & 0 & 0 & 0 & O \\
\hline 3 & 0 & 0 & 0 & 0 & 0 & 0 & 0 & 0 & 0 & 0 & 0 & 0 & 0 & 0 & $\circ$ & 0 \\
\hline 2 & 0 & 0 & $\circ$ & ० & 0 & 0 & 0 & 0 & & & & 0 & 0 & 0 & $\circ$ & o \\
\hline 1 & 0 & 0 & 0 & 0 & 0 & 0 & 0 & & & & & 0 & 0 & O & 0 & 0 \\
\hline & $\boldsymbol{r}$ & $N$ & $\omega$ & $A$ & VI & $a$ & $v$ & $\infty$ & 0 & $\overrightarrow{0}$ & 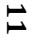 & $\vec{N}$ & $\overleftrightarrow{\omega}$ & $\vec{A}$ & $\vec{v}$ & $\sqrt{a}$ \\
\hline
\end{tabular}

Šema 1. Mapa eksperimentalnog zasada šljive sa pozicijama inokulisanih stabala (1-16: redovi, 1-29: broj stabla u redu, •-inokulisana stabla) 
Sekvenca izolata RS-68pl je deponovana u on-line bazu web sajta projekta SharCo po ID brojem 1635, a sekvenca izolata RS-67pl pod ID brojem 1636. Četiri sadnice su inokulisane PPV-D, a 4 sadnice PPV-Rec izolatom. Inokulacija je izvršena kalemljenjem pupoljka inokuluma na odabrane sadnice tehnikom čipbading (chip budding). Inokulisane sadnice nalaze se u sredini zasada (Šema 1).

Godinu dana pre sadnje su pregledom terena u okolini eksperimentalnog zasada markirana sva stabla Prunus vrsta domaćina virusa šarke šljive. U pravcu severa, na udaljenosti oko $70 \mathrm{~m}$ od eksperimentalnog zasada nalazi se mali zasad šljive sorte Stanley od 38 stabala (Slika 18) (u daljem tekstu: mali zasad šljive). Osim ovog zasada, u blizini su locirana i dva stabla šljive sorte Crvena ranka sa tipičnim simptomima šarke na lišću. Ova stabla se nalaze oko $40 \mathrm{~m}$ od eksperimentalnog zasada u pravcu jugo-istok (Slika 18). Sva locirana stabla su ispitana na prisustvo PPV IC-RT-PCR metodom. Detektovani izolati PPV su sekvencionirani $\mathrm{u}$ C-ter $\mathrm{NIb}-\mathrm{N}$-ter $\mathrm{CP}$ regionu genoma radi upoređivanja sa izolatima iz eksperimentalnog zasada. U narednim godinama, takođe su vršeni ovi pregledi, detektovane nove infekcije i sekvencionirani novootkriveni izolati.

Tokom perioda istraživanja u zasadu su redovno sprovođene sve agro- i pomotehničke mere, kao i standardna hemijska zaštita. Kruna stabala je pomotehničkim zahvatima formirana u vidu poboljšane piramide (5-7 skeletnih grana).

\subsubsection{Vizuelni pregled}

Sva stabla šljive su tokom četvorogodišnjeg ispitivanja (2008-2011) vizuelno pregledana na prisustvo simptoma virusa šarke na lišću. Pregled je vršen u tri termina tokom juna, jula i avgusta.

Svaka pojava simptoma koji ukazuju na prisustvo šarke je opisno dokumentovana. Proporcija listova sa simptomima ocenjivana je ocenom 1-4.

Opis ocena je dat u sledećoj tabeli: 
Tabela 5. Opisna ocena simptoma virusa šarke šljive

\begin{tabular}{cl}
\hline Ocena & Opis simptoma \\
\hline 1 & $2-3$ lista sa simptomima \\
2 & listovi sa simptomima na nekoliko grančica na jednoj skeletnoj grani \\
3 & listovi sa simptomima na nekoliko grančica na bar dve skeletne grane \\
4 & listovi sa simptomima na kompletnoj kruni \\
\hline
\end{tabular}

Izgled simptoma je opisivan sledećim oznakama: Mo (mozaik), PN (prosvetljavanje nerava) i PP (prstenaste pege). Intenzitet simptoma je ocenjivan numeričkim oznakama 1-4, gde ocena 1 predstavlja veoma blage simptome, a ocena 4 jako izražene simptome.

\subsubsection{Serološki test potvrđivanja prisustva virusa}

Tokom istraživanja, vršeno je serološko ispitivanje prisustva virusa šarke šljive u svim stablima u zasadu. Ispitivanje je sprovedeno DAS-ELISA metodom (Clark i Adams, 1977) sa reagensima AGRITEST S.r.l., Italija.

Svaki uzorak za ispitivanje sastojao se od 10 listova sakupljenih sa različitih delova krune jednog stabla.

DAS-ELISA test je sproveden po sledećem protokolu preporučenom od strane proizvođača reagenasa:

ELISA ploča (NUNC, Danska) je obložena sa specifičnim antitelima (pab PPV) pripremljenim u puferu za oblaganje ploča u razređenju 1:1000. U svaki otvor ploče naliveno je po $200 \mu \mathrm{l}$ pripremljenog razređenja. Obložena ploča je inkubirana u termostatu 2 sata na $37^{\circ} \mathrm{C}$.

Uzorci su pripremani u puferu za ekstrakciju (PBS-Tween + 2\% PVP) u razređenju 1:20. Nakon pripreme, ekstrakti su držani u frižideru na $4^{\circ} \mathrm{C}$. U testu su pored analiziranih uzoraka korišćene i pozitivna i negativna kontrola.

Nakon inkubiranja, obložena ploča je isprana sa PBS-Tween puferom (3 puta po $3 \mathrm{~min})$.

Po ispranju, ploča je nalivena sa po $200 \mu$ pripremljenog uzorka po otvoru ploče, pokrivena transparentnom folijom i inkubirana u termostatu 2 sata na $37^{\circ} \mathrm{C}$.

Nakon inkubiranja, ploča je isprana sa PBS-Tween puferom (3 puta po 3 $\min )$. 
Isprana ploča je obložena sa antitelima konjugovanih sa enzimom (pabAP PPV) pripremljenim u konjugat puferu u razređenju 1:500. U svaki otvor ploče naliveno je po $200 \mu \mathrm{l}$ pripremljenog razređenja. Obložena ploča je inkubirana preko noći u frižideru na $4^{\circ} \mathrm{C}$.

Nakon inkubiranja, ploča je isprana sa PBS-Tween puferom (3 puta po 3 $\min )$.

U otvore ploče naliveno je razređenje nitrofenil fosfata (p-nitrophenyl phosphate-PNP) u supstratnom puferu u odnosu $1 \mathrm{mg} / \mathrm{ml}$. U svaki otvor ploče naliveno je po $200 \mu \mathrm{l}$ pripremljenog razređenja. Ploča je inkubirana na sobnoj temperaturi $\left(18-25^{\circ} \mathrm{C}\right)$ na tamnom mestu.

Očitavanje rezultata je sprovedeno na ELISA čitaču Multiskan MCC/340 (Labsystems, Finska) odabirom filtera od 405 nm nakon 60-120 min.

Kao pozitivan, smatran je svaki uzorak sa očitanom vrednošću apsorpcije bar dva puta višom od vrednosti apsorpcije negativne kontrole.

\subsubsection{Molekularni test tipiziranja sojeva detektovanih izolata virusa šarke}

Svi ispitivani uzorci, koji su u ELISA testu bili pozitivni, dalje su okarakterisani primenom molekularne IC-RT-PCR metode. Pored novozaraženih stabala, tokom istraživanja redovno su kontrolisana i inokulisana stabla.

Ispitivanje je urađeno po metodologiji opisanoj u poglavlju 4.1.2. Detekcija $i$ tipiziranje izolata virusa šarke. Na ovaj način određena je pripadnost izolata odgovarajućem soju virusa šarke.

Nakon tipiziranja, izvršeno je sekvencioniranje C-ter NIb-N-ter CP regiona genoma sa ciljem da se dobijene sekvence međusobno porede, kao i sa sekvencama izolata iz okoline eksperimentalnog zasada šljive. Priprema uzoraka za sekvencioniranje opisana je u poglavlju 4.1.3. Sekvencioniranje delova genoma odabranih izolata. 


\subsubsection{Filogenetska analiza}

Dobijene sekvence su obrađene i međusobno upoređivane u programu Bioedit sequence alignment editor (verzija 7.0.5.3). Za proučavanje filo-geografske istorije diverziteta izolata primenjen je program TCS (verzija 1.21).

\subsubsection{Praćenje brojnosti i vrsta lisnih vaši u eksperimentalnom zasadu}

Tokom poslednje tri godine sprovedenog istraživanja (2009-2011), u eksperimentalnom zasadu vršeno je praćenje prisustva vrsta i brojnosti lisnih vaši.

Za hvatanje krilatih formi vaši primenjena je Sticky-shoot metoda uz izvesnu modifikaciju (Avinent et al., 1993; Cambra et al., 2000; Marroquin et al., 2004).

Metoda se sastoji u primeni lepka u vidu spreja (Soveurode ${ }^{\circledR}$ aérosol, Scots, Švajcarska) na 5 potpuno razvijenih listova po jednom stablu (Slika 19). Lepak je prskanjem nanošen na po 8 stabala šljive nasumično odabranih u zasadu. Nakon intervala od 7-14 dana, izvršeno je skidanje oprskanih listova (Slika 20) i prskanje novih.

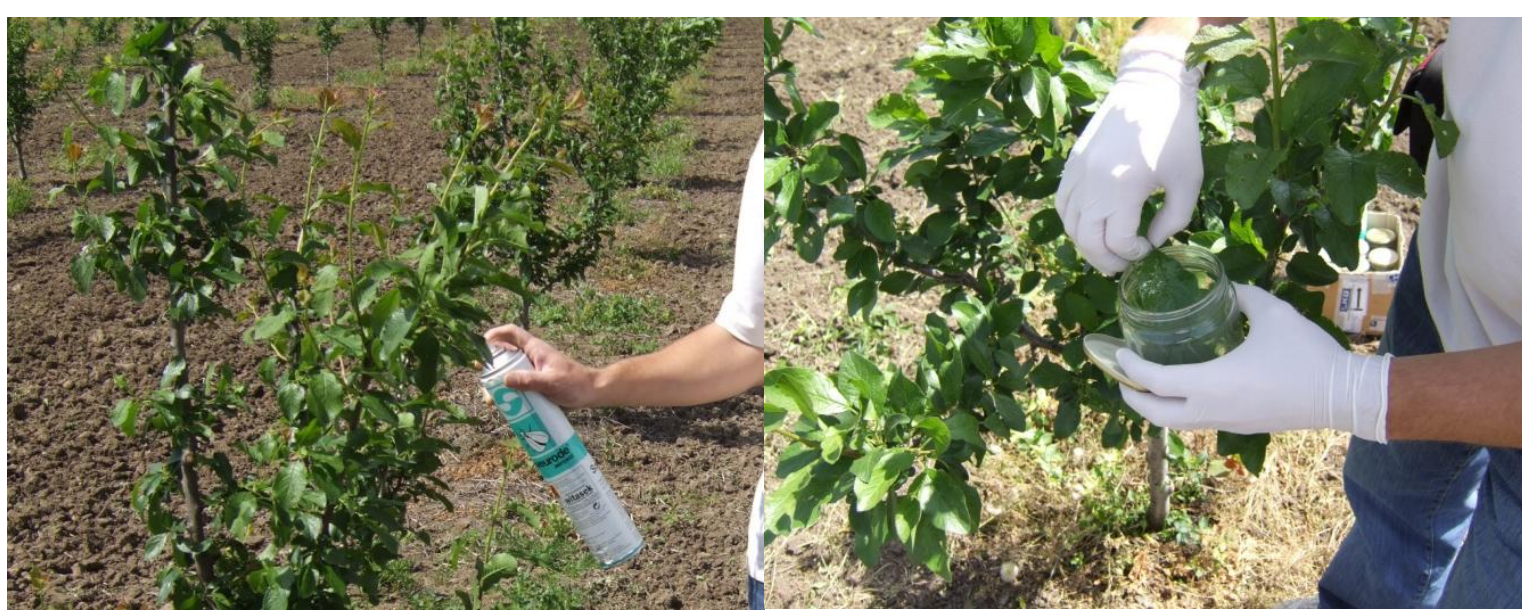

Slike 19 i 20. Nanošenje aerosola i skidanje listova sa uhvaćenim insektima

Skinuto lišće je stavljano u staklene tegle i dalje obrađivano u laboratoriji. Za skidanje vaši i drugih insekata sa listova, primenjen je terpentin (Zvezda, Gornji Milanovac) koji je dodat u tegle sa listovima. Nakon 30-60 min, uz pomoć četkice, preostale vaši i drugi insekti su skinuti sa listova. Insekti su pomoću plastičnog sita 
odvojeni od terpentina i isprani sa $96 \%$ etanolom radi uklanjanja ostataka terpentina. Ovde su, za razliku od originalne procedure, umesto ispiranja u blagoj sapunici, insekti isprani etanolom. Kod primene sapunice dolazilo je do međusobnog slepljivanja insekata, kao i ostalih primesa sa listova i nemogućnosti razdvajanja bez oštećenja. Nakon ispiranja, vaši su odvojene od drugih insekata i do determinacije čuvane u $70 \%$ etanolu.

Determinaciju vaši obavila je prof. dr Olivera Petrović-Obradović na Poljoprivrednom fakultetu Univerziteta u Beogradu. 


\section{REZULTATI}

\subsection{Rasprostranjenost sojeva šarke šljive u Srbiji}

\subsubsection{Rezultati IC-RT-PCR analiza}

Molekularnom IC-RT-PCR metodom ukupno je analizirano 283 uzoraka šljive i kajsije iz 94 voćnjaka i sa 6 usamljenjih stabala u 12 okruga Srbije. Analiza obuhvata 4 odvojene PCR reakcije sa PPV-M i PPV-D specifičnim prajmerima.

Pojava fragmenata očekivane veličine od 467 bp u PCR reakciji sa P4-P3M i P4-P3D setovima prajmera, fragmenta od 880 bp u reakciji sa setom CIP-M/CIPMR i fragmenta od 468 bp sa setom prajmera CIP-D/CIP-DR smatrana je za pozitivnu reakciju.

Analizom umnoženih fragmenata virus šarke je detektovan kod 278 uzoraka (Tabela 6 i grafikon 1).

Upoređivanjem rezultata PCR reakcija određivana je pripadnost izolata odgovarajućem soju PPV. Rezultati analize svih ispitivanih uzoraka dati su u prilogu 1.

Izolati koji su dali pozitivnu reakciju sa setom prajmera P4-P3M na CP regionu i CIP-M/CIP-MR na CI regionu genoma PPV pripadaju PPV-M soju. PPV-M soj je utvrđen kod 15 uzoraka, odnosno 5,4\%. 
Tabela 6. Zastupljenost sojeva virusa šarke u svim analiziranim uzorcima

\begin{tabular}{lcc}
\hline Utvrđeni soj & Broj uzoraka & \% \\
\hline PPV-M & 15 & 5,4 \\
PPV-D & 73 & 26,3 \\
PPV-Rec & 155 & 55,7 \\
M+ D & 4 & 1,4 \\
M+ Rec & 6 & 2,2 \\
D+ Rec & 24 & 8,6 \\
M+ D+ Rec & 1 & 0,4 \\
\hline UKUPNO & $\mathbf{2 7 8}$ & $\mathbf{1 0 0}$ \\
\hline
\end{tabular}

Izolati koji su dali pozitivnu reakciju sa setom prajmera P4-P3D na CP regionu i CIP-D/CIP-DR na CI regionu pripadaju PPV-D soju. PPV-D soj je detektovan kod 73 uzorka ili $26,3 \%$.

PPV-Rec izolati su dali pozitivnu reakciju samo sa setom prajmera P4-P3M na CP regionu i CIP-D/CIP-DR na CI regionu. PPV-Rec soj je detektovan kod 155 uzorka $(55,7 \%)$.

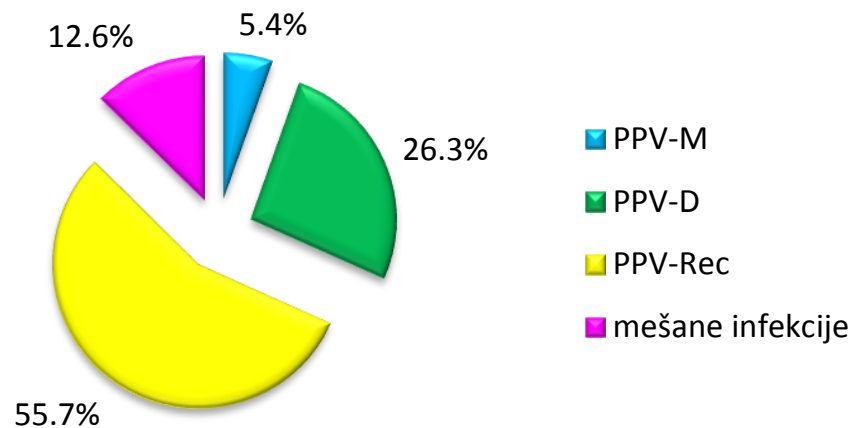

Grafikon 1. Zastupljenost virusa šarke šljive u svim ispitivanim uzorcima

Mešane infekcije su utvrđene kod 35 uzorka (12,6\%). Kod 34 uzorka je utvrđeno prisustvo dva soja u testiranom uzorku, dok je kod jednog uzorka potvrđeno prisustvo sva tri ispitivana soja PPV (Grafikon 2).

Mešana infekcija tipa PPV-M+PPV-Rec je prisutna kod onih uzoraka koji su dali pozitivnu reakciju sa sledećim kombinacijama prajmera: P4-P3M, CIP-M/CIPMR i CIP-D/CIP-DR. Ovaj tip mešane infekcije utvrđen je kod 6 uzoraka.

Mešana infekcija tipa PPV-D+PPV-Rec je prisutna kod onih uzoraka koji su dali pozitivnu reakciju sa sledećim kombinacijama prajmera: P4-P3M, P4-P3D i CIP-D/CIP-DR. Ovaj tip mešane infekcije utvrđen je kod 24 uzoraka. 
Kod 5 uzoraka dobijen je pozitivan rezultat u sve 4 PCR reakcije. U ovom slučaju prisutni su PPV-M i PPV-D soj, ali postoji mogućnost da je prisutan i PPVRec soj. Da bi se utvrdilo da li je i rekombinantan soj prisutan, sprovedena je i PCR reakcija sa setom prajmera mD5-mM3. Nakon sprovođenja ove reakcije samo je u 1 uzorku dobijena pozitivna reakcija. Ovim je kod uzorka šljive potvrđena trostruka infekcija, dok su u ostala 4 uzorka prisutni samo PPV-M i PPV-D soj.

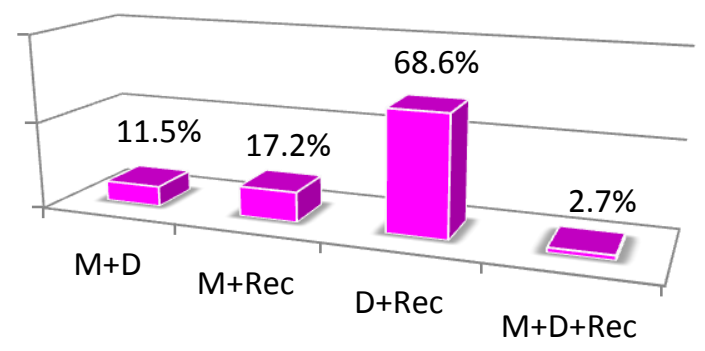

Grafikon 2. Struktura utvrđenih mešanih infekcija u svim ispitivanim uzorcima

Kod 5 uzoraka nije dobijena pozitivna reakcija ni u jednoj od sprovedene 4 PCR reakcije. Kod ovih uzoraka nije utvrđeno prisustvo virusa šarke šljive.

\subsubsection{Rasprostranjenost sojeva šarke u uzorcima šljive}

Analiza raširenosti sojeva PPV sprovedena je analizom 263 uzoraka šljive iz 85 voćnjaka i sa 6 usamljenih stabala. Analiziran je 261 uzorak sorti $P$. domestica L. i 2 uzorka P. cerasifera Ehrh.

Virus šarke je potvrđen kod 258 analiziranih uzoraka šljive (Tabela 7 i grafikon 3).

Tabela 7. Zastupljenost sojeva virusa šarke u analiziranim uzorcima šljive

\begin{tabular}{lcc}
\hline Utvrđeni soj & Broj uzoraka & $\mathbf{\%}$ \\
\hline M & 14 & $\mathbf{5 , 4}$ \\
D & 72 & $\mathbf{2 7 , 9}$ \\
Rec & 138 & $\mathbf{5 3 , 5}$ \\
M+ D & 4 & $\mathbf{1 , 5}$ \\
M+ Rec & 6 & $\mathbf{2 , 3}$ \\
D+ Rec & 23 & $\mathbf{9}$ \\
M+ D+ Rec & 1 & $\mathbf{0 , 4}$ \\
\hline UKUPNO & $\mathbf{2 5 8}$ & $\mathbf{1 0 0}$ \\
\hline
\end{tabular}




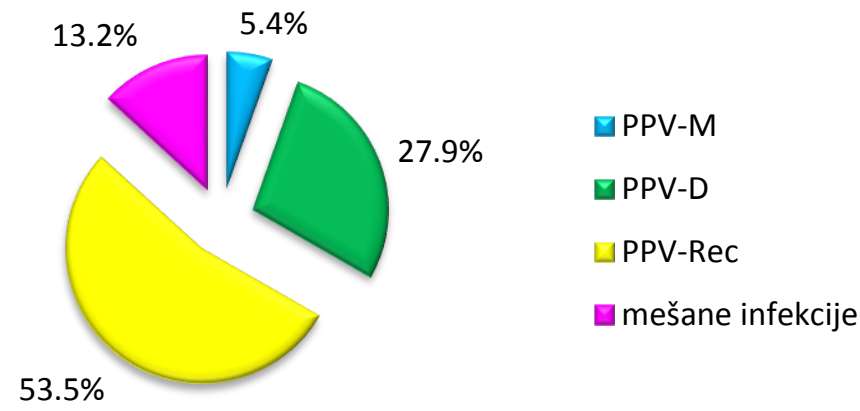

Grafikon 3. Zastupljenost virusa šarke šljive u ispitivanim uzorcima šljive

U uzorcima je dominantno prisutan PPV-Rec soj, koji je potvrđen kod 138 uzoraka šljive (53,5\%). Rekombinantni soj je utvrđen i u mešanim infekcijama kod 30 uzoraka. Ukupno, u pojedinačnim i mešanim infekcijama, PPV-Rec soj je prisutan kod 65,2\% od ukupnog broja pozitivnih uzoraka.

PPV-D soj je utvrđen kod 72 uzorka šljive $(27,9 \%)$ u pojedinačnoj infekciji i kod 28 uzoraka u mešanim infekcijama. Ukupno, PPV-D soj je prisutan kod 38,8\% uzoraka.

PPV-M soj je utvrđen kod svega 14 uzoraka šljive $(5,4 \%)$ u pojedinačnoj infekciji, i kod 11 uzoraka u mešanim infekcijama, što ukupno čini 9,6\% uzoraka.

Kod šljive je utvrđen i značajan udeo mešanih infekcija (Grafikon 4). Kod 34 uzorka $(13,2 \%)$ su utvrđene mešane infekcije. Među mešanim infekcijama najbrojniji su uzorci u kojima je utvrđeno prisustvo PPV-D i PPV-Rec soja (23 uzorka). Slede 6 uzoraka u kojima je utvrđeno prisustvo PPV-M i PPV-Rec soja; i 4 uzorka u kojima su detektovani i PPV-M i PPV-D soj. Tokom ovog istraživanja potvrđena je i trostruka infekcija jednog uzorka šljive.

Kod 5 uzoraka šljive nije utvrđeno prisustvo virusa šarke šljive iako su na listovima bili prisutni simptomi nalik onima koje izaziva PPV. 


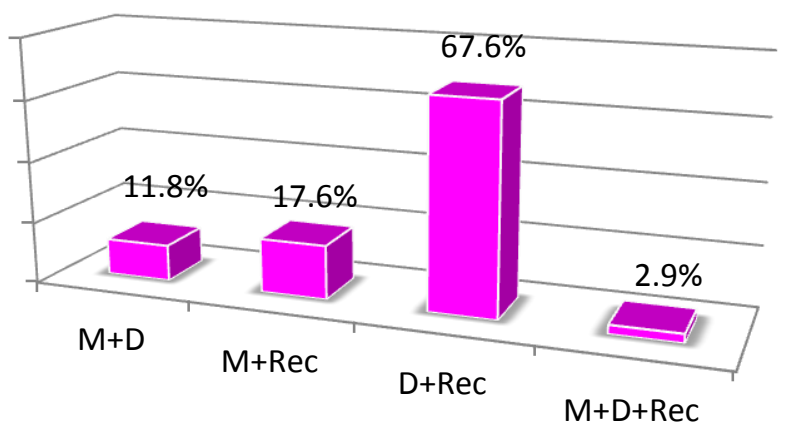

Grafikon 4. Struktura utvrđenih mešanih infekcija u uzorcima šljive

\subsubsection{Rasprostranjenost sojeva šarke u uzorcima kajsije}

Analiza raširenosti sojeva PPV sprovedena je analizom 20 uzoraka kajsije iz 9 voćnjaka. Virus šarke je potvrđen kod svih analiziranih uzoraka (Tabela 8 i grafikon 5).

Tabela 8. Zastupljenost sojeva virusa šarke u analiziranim uzorcima kajsije

\begin{tabular}{lcc}
\hline Utvrđeni soj & Broj uzoraka & $\mathbf{\%}$ \\
\hline M & 1 & $\mathbf{5}$ \\
D & 1 & $\mathbf{5}$ \\
Rec & 17 & $\mathbf{8 5}$ \\
D+ Rec & 1 & $\mathbf{5}$ \\
\hline UKUPNO & $\mathbf{2 0}$ & $\mathbf{1 0 0}$ \\
\hline
\end{tabular}

U uzorcima je dominantno prisutan PPV-Rec soj, koji je potvrđen kod 17 uzoraka kajsije (85\%). Rekombinantni soj je utvrđen i u jednom uzorku sa mešanom infekcijom. Ukupno, u pojedinačnim i mešanim infekcijama, PPV-Rec soj je prisutan kod 90\% ispitivanih uzoraka.

PPV-D i PPV-M soj su utvrđeni u po 1 uzorku kajsije (5\%). PPV-D soj je utvrđen i u 1 uzorku u mešanoj infekciji. Ukupno, PPV-D soj je prisutan kod 10\% uzoraka.

Kod kajsije je utvrđen samo 1 uzorak (5\%) sa mešanom infekcijom, gde su prisutni PPV-D i PPV-Rec soj. 


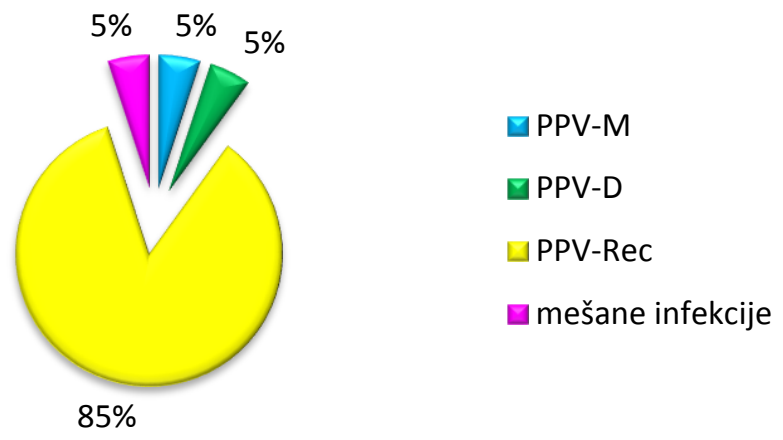

Grafikon 5. Zastupljenost virusa šarke šljive u ispitivanim uzorcima kajsije

\subsubsection{Zastupljenost sojeva šarke na nivou zasada}

Rezultati istraživanja prisustva virusa šarke u zasadima šljive i kajsije pokazuju da je u 44 zasada utvrđeno prisustvo samo jednog soja virusa šarke šljive. U 32 voćnjaka utvrđen je samo PPV-Rec soj, u 11 PPV-D soj, a u 1 voćnjaku samo PPV-M soj.

Prisustvo dva soja potvrđeno je takođe u 44 zasada. Prisustvo PPV-D i PPVRec soja utvrđeno je u 34 zasada, PPV-M i PPV-Rec soja u 6 zasada, a prisustvo PPV-M i PPV-D soja u 4 zasada.

Sva tri soja virusa šarke utvrđena su u samo 5 od ispitivanih 93 zasada.

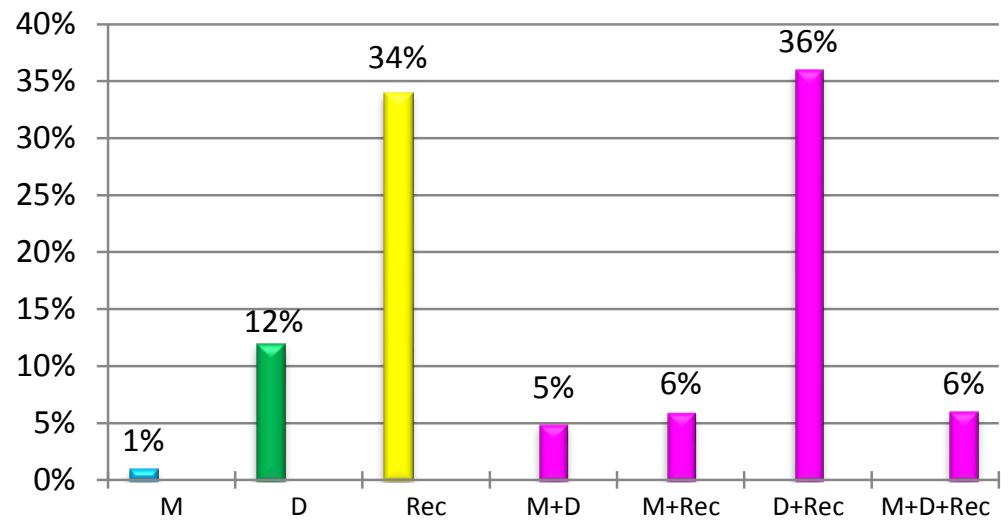

Grafikon 6. Procentualna zastupljenost zasada u kojima je utvrđeno prisustvo jednog, dva $i$ sva tri soja virusa šarke šljive 


\subsubsection{Rasprostranjenost sojeva na nivou okruga}

Geografska distribucija sojeva šarke u analiziranim okruzima data je na slici 21. U ispitivanim okruzima prisutna su sva tri ispitivana soja šarke: PPV-M, PPV-D i PPV-Rec.

U Jablaničkom, Kolubarskom, Kosovsko-Mitrovačkom, Mačvanskom, Moravičkom, Šumadijskom, Topličkom i Zlatiborskom okrugu je dominantno raširen PPV-Rec soj.

Sa druge strane, u Nišavskom, Pirotskom, Rasinskom i Zaječarskom okrugu PPV-D soj je dominantno utvrđen.

Mešane infekcije su utvrđene u gotovo svim okruzima, izuzev Jablaničkog i Kosovsko-Mitrovačkog.

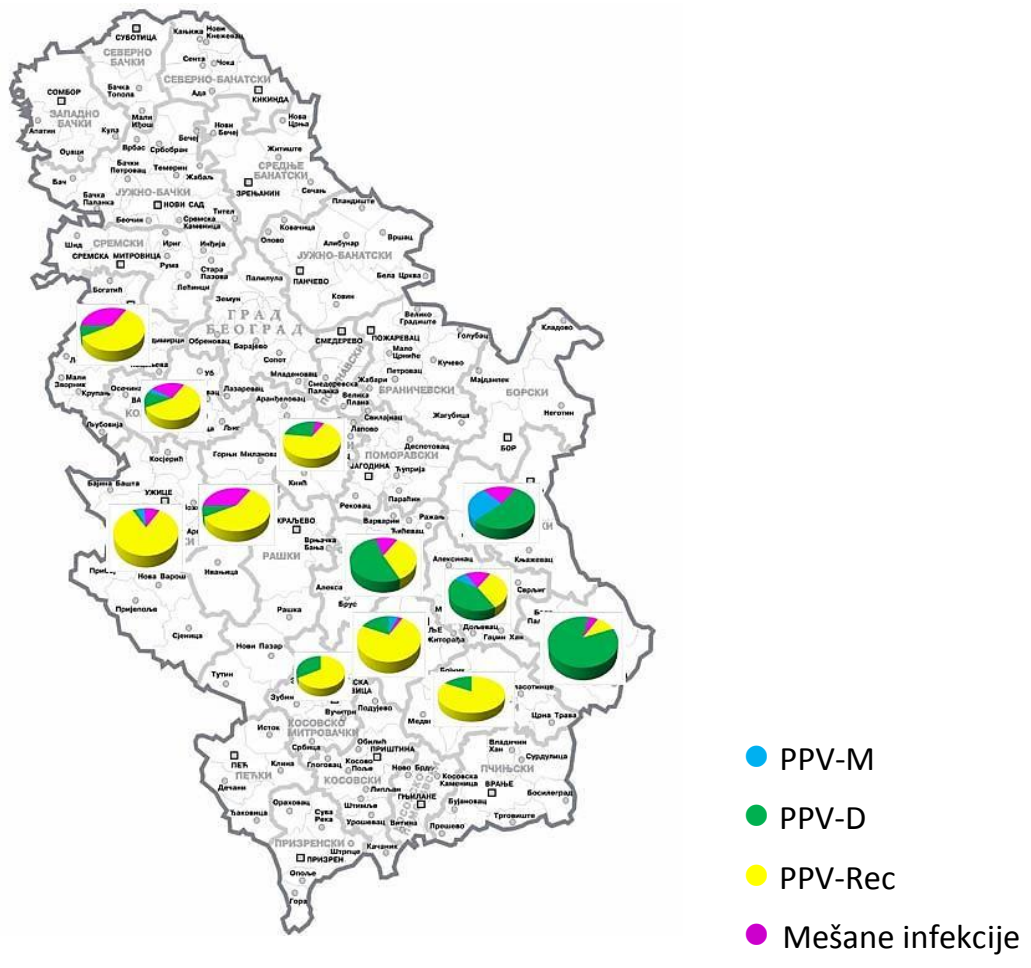

Slika 21. Distribucija sojeva šarke šljive u ispitivanim okruzima Srbije 


\subsubsection{Analiza nukleotidnih sekvenci C-ter NIb-N-ter CP i P3-6K1 regiona genoma}

Analiza sekvenci C-ter NIb-N-ter CP i P3-6K1 regiona genoma urađena je kod 41 odabranog izolata (Tabela 9). Najveći broj izolata (39) je poreklom iz šljive, a 2 izolata iz kajsije. Od ukupnog broja, 23 izolata pripada PPV-Rec soju, 15 izolata PPV-D soju i 3 izolata PPV-M soju. Ukupno je sekvencionirano više od 1200 nukleotida za svaki izolat što predstavlja oko 13\% kompletnog genoma.

Tabela 9. Izolati PPV odabrani za sekvencioniranje C-ter NIb-N-ter CP i P3-6K1 regiona

\begin{tabular}{|c|c|c|c|c|c|c|}
\hline BROJ & $\begin{array}{l}\text { REDNI BROJ } \\
\text { IZOLATA }\end{array}$ & $\begin{array}{l}\text { OZNAKA } \\
\text { IZOLATA }\end{array}$ & DOMAĆIN & SOJ & $\begin{array}{c}\text { SHARCO ID* } \\
\text { NIb-CP }\end{array}$ & $\begin{array}{l}\text { SHARCO ID } \\
\text { P3-6K1-CI }\end{array}$ \\
\hline 1 & 6 & RS-02pl & P. domestica & $\mathrm{D}$ & 113 & 112 \\
\hline 2 & 24 & RS-03pl & P. domestica & $\operatorname{Rec}$ & 115 & 114 \\
\hline 3 & 27 & RS-04pl & P. domestica & $\operatorname{Rec}$ & 493 & 492 \\
\hline 4 & 28 & RS-05pl & P. domestica & $\operatorname{Rec}$ & 495 & 494 \\
\hline 5 & 29 & RS-06pl & P. domestica & $\operatorname{Rec}$ & 117 & 116 \\
\hline 6 & 36 & RS-07pl & P. domestica & $\mathrm{D}$ & 119 & 118 \\
\hline 7 & 37 & RS-09pl & P. domestica & $\operatorname{Rec}$ & 123 & 122 \\
\hline 8 & 40 & RS-10pl & P. domestica & $\operatorname{Rec}$ & 497 & 496 \\
\hline 9 & 44 & $\mathrm{RS}-11 \mathrm{pl}$ & P. domestica & $\operatorname{Rec}$ & 125 & 124 \\
\hline 10 & 46 & RS-12pl & P. domestica & $\mathrm{M}$ & 127 & 126 \\
\hline 11 & 49 & RS-13pl & P. domestica & $\operatorname{Rec}$ & 499 & 498 \\
\hline 12 & 56 & RS-14pl & P. domestica & $\operatorname{Rec}$ & 129 & 128 \\
\hline 13 & 57 & RS-15pl & P. domestica & $\operatorname{Rec}$ & 131 & 130 \\
\hline 14 & 59 & RS-16pl & P. domestica & $\operatorname{Rec}$ & 881 & 880 \\
\hline 15 & 65 & RS-18pl & P. domestica & D & 133 & 132 \\
\hline 16 & 69 & RS-19pl & P. domestica & $\mathrm{M}$ & 135 & 134 \\
\hline 17 & 91 & RS-25ap & P. armeniaca & $\operatorname{Rec}$ & 141 & 140 \\
\hline 18 & 99 & RS-26pl & P. domestica & $\mathrm{D}$ & 879 & 878 \\
\hline 19 & 109 & $\mathrm{RS}-27 \mathrm{pl}$ & P. domestica & M & 503 & 502 \\
\hline 20 & 131 & RS-29pl & P. domestica & $\mathrm{D}$ & 145 & 144 \\
\hline 21 & 153 & RS-34pl & P. domestica & $\mathrm{D}$ & 1081 & 1080 \\
\hline 22 & 155 & RS-35pl & P. domestica & $\operatorname{Rec}$ & 1083 & 1082 \\
\hline 23 & 158 & RS-36pl & P. domestica & $\operatorname{Rec}$ & 1085 & 1084 \\
\hline 24 & 173 & RS-37pl & P. domestica & $\operatorname{Rec}$ & 1087 & 1086 \\
\hline 25 & 176 & RS-38pl & P. domestica & $\operatorname{Rec}$ & 1089 & 1088 \\
\hline 26 & 180 & RS-39pl & P. domestica & $\operatorname{Rec}$ & 1091 & 1090 \\
\hline 27 & 186 & RS-42pl & P. domestica & $\operatorname{Rec}$ & 1097 & 1096 \\
\hline 28 & 189 & RS-43pl & P. domestica & $\mathrm{D}$ & 1099 & 1098 \\
\hline 29 & 191 & $\mathrm{RS}-44 \mathrm{pl}$ & P. domestica & $\operatorname{Rec}$ & 1101 & 1100 \\
\hline 30 & 195 & RS-45pl & P. domestica & $\mathrm{D}$ & 1103 & 1102 \\
\hline 31 & 201 & RS-46pl & P. domestica & $\mathrm{D}$ & 1105 & 1104 \\
\hline 32 & 204 & RS-52pl & P. domestica & $\operatorname{Rec}$ & 1117 & 1116 \\
\hline 33 & 207 & RS-53pl & P. domestica & $\operatorname{Rec}$ & 1119 & 1118 \\
\hline 34 & 212 & RS-54pl & P. domestica & $\operatorname{Rec}$ & 1121 & 1120 \\
\hline 35 & 215 & RS-55pl & P. domestica & $\mathrm{D}$ & / & 1122 \\
\hline 36 & 218 & RS-56pl & P. domestica & $\operatorname{Rec}$ & 1125 & 1124 \\
\hline 37 & 224 & RS-57pl & P. domestica & $\mathrm{D}$ & 1127 & 1126 \\
\hline 38 & 232 & RS-59pl & P. domestica & D & 1129 & 1128 \\
\hline 39 & 241 & RS-60pl & P. domestica & D & 1131 & 1130 \\
\hline 40 & 246 & RS-61ap & P. armeniaca & $\mathrm{D}$ & 1133 & 1132 \\
\hline 41 & 249 & RS-62pl & P. domestica & D & 1135 & 1134 \\
\hline
\end{tabular}

*ID broj sekvence u on-line PPV bazi sekvenci projekta SharCo 


\subsubsection{Analiza sekvenci C-ter NIb-N-ter CP regiona genoma}

Umnoženi PCR produkti za sekvencioniranje odabranih PPV-Rec i PPV-M izolata su dobijeni u reakciji sa setom prajmera P4-P3M, a kod PPV-D izolata sa setom prajmera P4-P3D.

Dobijene nukleotidne sekvence su deponovane $\mathrm{u}$ on-line bazu web sajta projekta SharCo (ID brojevi sekvenci su dati u tabeli 9). Dobijene sekvence su obrađene i višestruko uparene primenom ClustalW metode u programu BioEdit. Filogenetsko stablo (NJ metod primenom Kimura-2 parametra) je rekonstruisano u programu MEGA5.

Upoređujući sekvence PPV izolata iz ovog regiona genoma utvrđeno je da svi poseduju DAG tripeptid (triplet aminokiselina asp-ala-gly) koji se smatra esencijalnim za prenošenje virusa lisnim vašima (pozicije nukleotida 8607-8615 prema sekvenci izolata PS: GenBank AJ243957). Kod PPV-Rec i PPV-M izolata sekvenca DAG tripeptida je GAT GCA GGA, dok je kod PPV-D izolata ova sekvenca

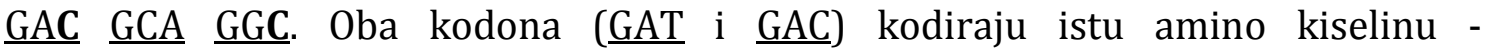
asparaginsku, dok kodoni GGA i GGC kodiraju glicin.

Filogenetsko stablo rekonstruisano od nukleotidnih sekvenci C-ter NIb-Nter CP regiona genoma jasno pokazuje tri klastera (grupe) izolata koji odgovaraju PPV-M, PPV-D i PPV-Rec sojevima (Slika 22).

Genetička udaljenost izolata je proračunata primenom bootstrap modela varijanse sa Kimura 2-P modelom zamene nukleotida. Vrednosti procenjene genetičke udaljenosti i standardne greške (SE) date su u tabeli 10.

Tabela 10. Vrednosti genetičke udaljenosti 41 izolata unutar i između klastera PPV-M, PPV-D i PPV-Rec izolata

\begin{tabular}{|c|c|c|c|}
\hline & PPV-M & PPV-D & PPV-Rec \\
\hline PPV-M (3 izolata) & $\mathbf{0 , 0 1 2} \pm 0,004^{*}$ & $0,273 \pm 0,028$ & $0,060 \pm 0,010$ \\
\hline PPV-D (15 izolata) & & $\mathbf{0 , 0 2 6} \pm 0,004$ & $0,273 \pm 0,025$ \\
\hline PPV-Rec (23 izolata) & & & $\mathbf{0 , 0 1 7} \pm 0,003$ \\
\hline
\end{tabular}


Sekvence dobijene tokom izrade ove disertacije su upoređene sa još 49 sekvenci PPV izolata iz Srbije (Jevremović, 2008). Ukupno je upoređeno 90 sekvenci sva tri soja virusa šarke. Rekonstruisano je filogenetsko stablo (Slika 23) i procenjena genetička udaljenost svih izolata poreklom iz naše zemlje (Tabela 11).

Tabela 11. Vrednosti genetičke udaljenosti 90 izolata unutar i između klastera PPV-M, PPV-D i PPV-Rec izolata

\begin{tabular}{lccc}
\hline & PPV-M & PPV-D & PPV-Rec \\
\hline PPV-M (23 izolata) & $\mathbf{0 , 0 2 0} \pm 0,003$ & $0,270 \pm 0,031$ & $0,067 \pm 0,012$ \\
PPV-D (21 izolat) & & $\mathbf{0 , 0 2 8} \pm 0,004$ & $0,250 \pm 0,030$ \\
PPV-Rec (46 izolata) & & & $\mathbf{0 , 0 1 7} \pm 0,003$ \\
\hline
\end{tabular}

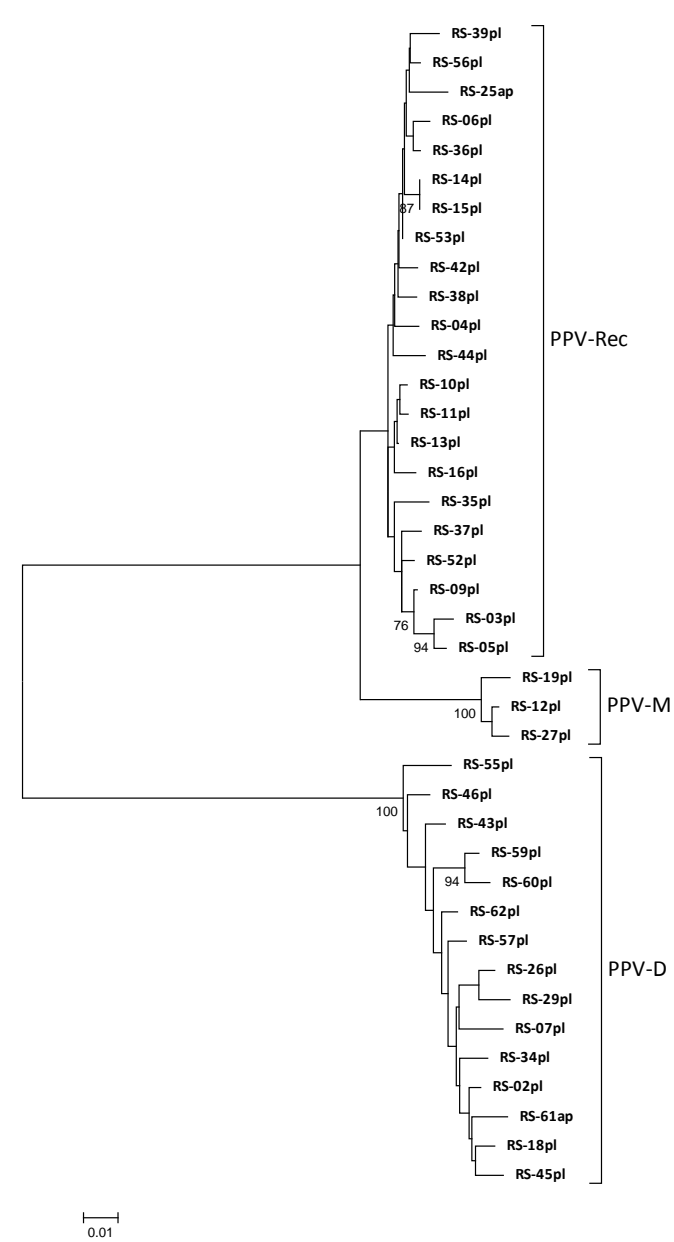

Slika 22. Filogenetsko stablo rekonstruisano iz 447 bp fragmenta 41 PPV izolata. Prikazane su bootstrap vrednosti $>75 \%$. 


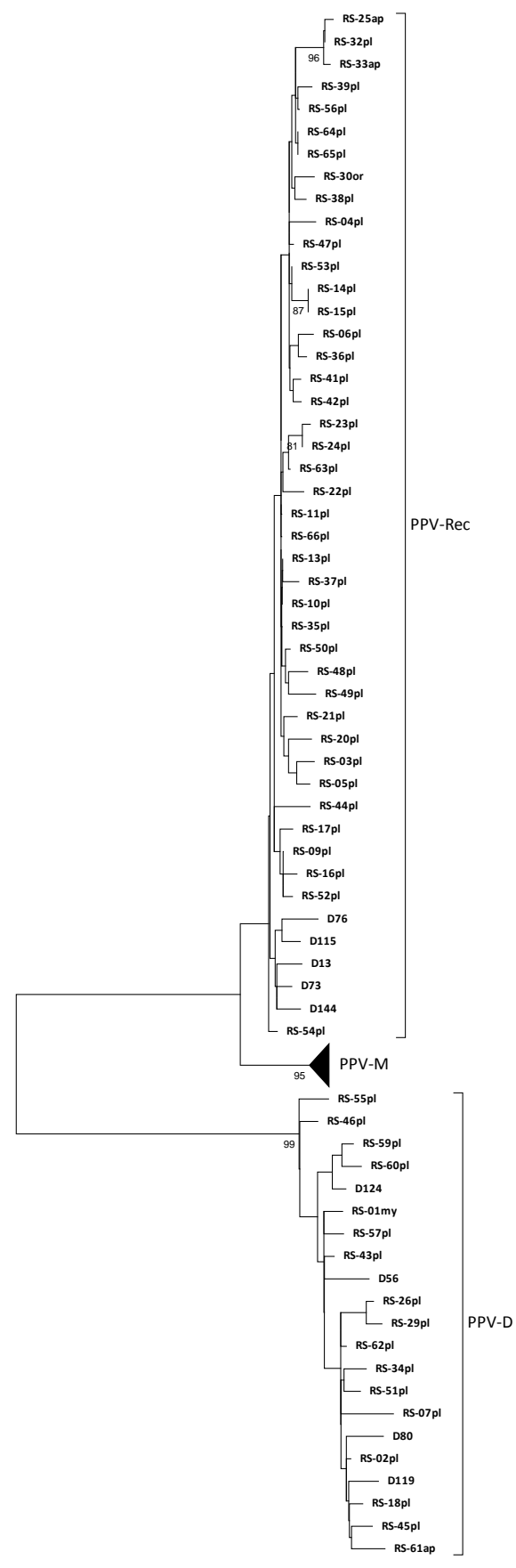

Slika 23. Filogenetsko stablo rekonstruisano iz 447 bp fragmenta 90 PPV izolata. Prikazane su bootstrap vrednosti $>75 \%$.

Mreža genealoške (rodoslovne) povezanosti C-ter NIb-N-ter CP sekvenci 21 PPV-D izolata je rekonstruisana radi procene njihove genealoške povezanosti (Slika 24). Analiza je sprovedena TCS programom (verzija 1.21) koji uključuje metod statističke parsimonije - SP (najmanje evolucione promene) baziran na 
kriterijumima koje su definisali Templeton et al. (1992). SP metoda je zasnovana na kriterijumu parsimonije sa statističkim proračunom za procenu limita pretpostavke parsimonije (parsimony assumption), odn. verovatnoći da je razlika u nukleotidnoj sekvenci dva varijanta (izolata) prouzrokovana pojedinačnim, a ne višestrukim slučajevima mutacije na jednom mestu. U analizi je zadat limit parsimonije $94 \%$ sa maksimalnih 8 mutacionih promena. Rekonstruisana mreža genealoške povezanosti PPV-D izolata ukazuje na veliku divergentnost analiziranih izolata, kao i da povezanost srodnih sekvenci nije uslovljena geografskim poreklom izolata niti vrstom domaćina.

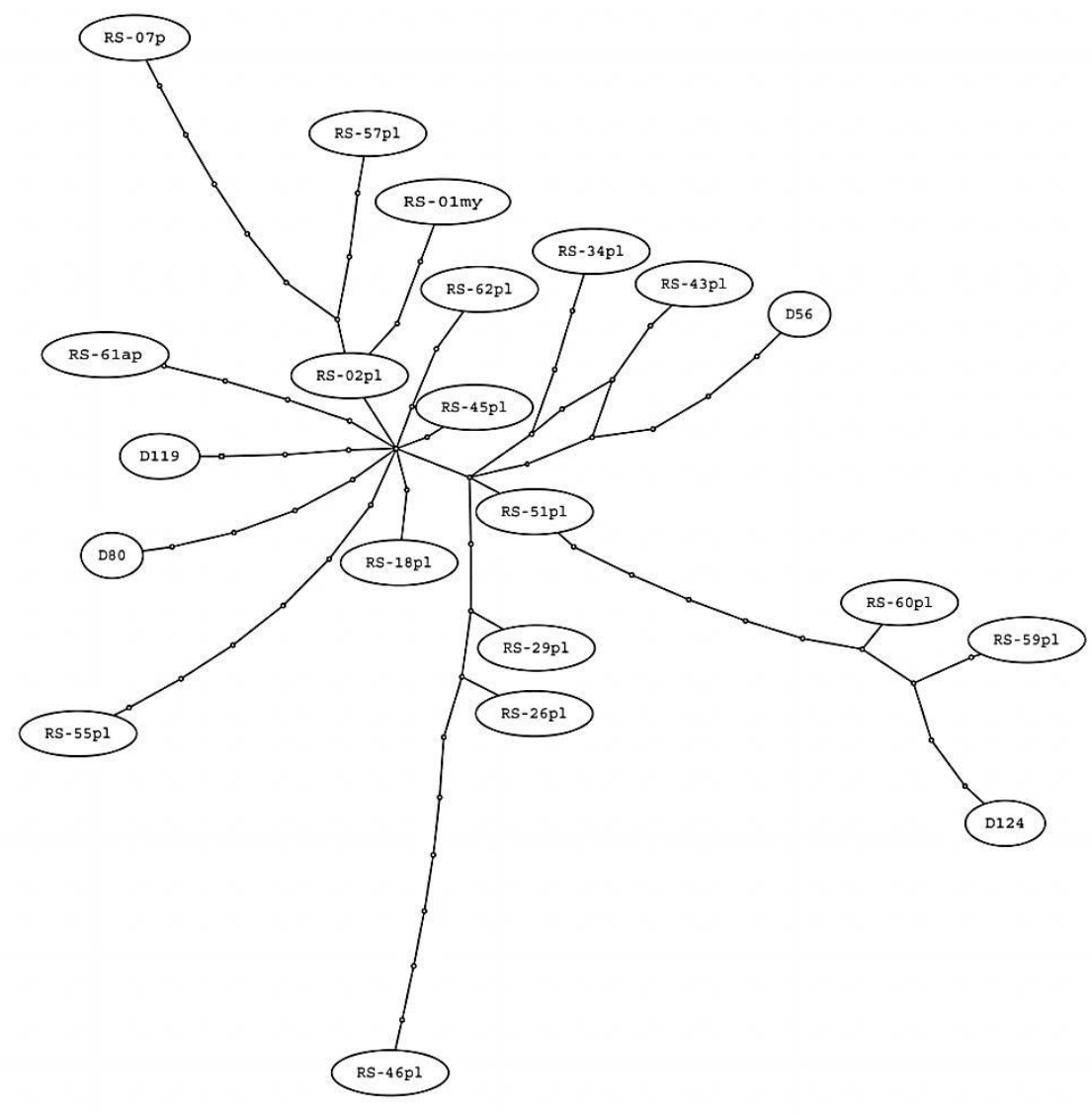

Slika 24. Mreža genealoške povezanosti sekvenci 21 PPV-D izolata. Svaka linija predstavlja pojedinačnu mutaciju (zamenu nukleotida). Dužine linija nisu signifikantne. Krugovi (o) predstavljaju intermedijarne sekvence izolata koji nisu prisutni u uzorcima.

Rekonstruisana mreža genealoške povezanosti C-ter NIb-N-ter CP sekvenci 46 PPV-Rec izolata je prikazana na slici 25. TCS analiza je sprovedena na nivou parsimonije 95\%, a maksimalan broj mutacionih promena je 7. Kod PPV-Rec izolata primećuje se veća povezanost nt sekvenci analiziranih izolata u odnosu na 
analizu PPV-D izolata. Analiza pokazuje da ne postoji povezanost srodnih sekvenci sa geografskim poreklom izolata niti sa vrstom domaćina

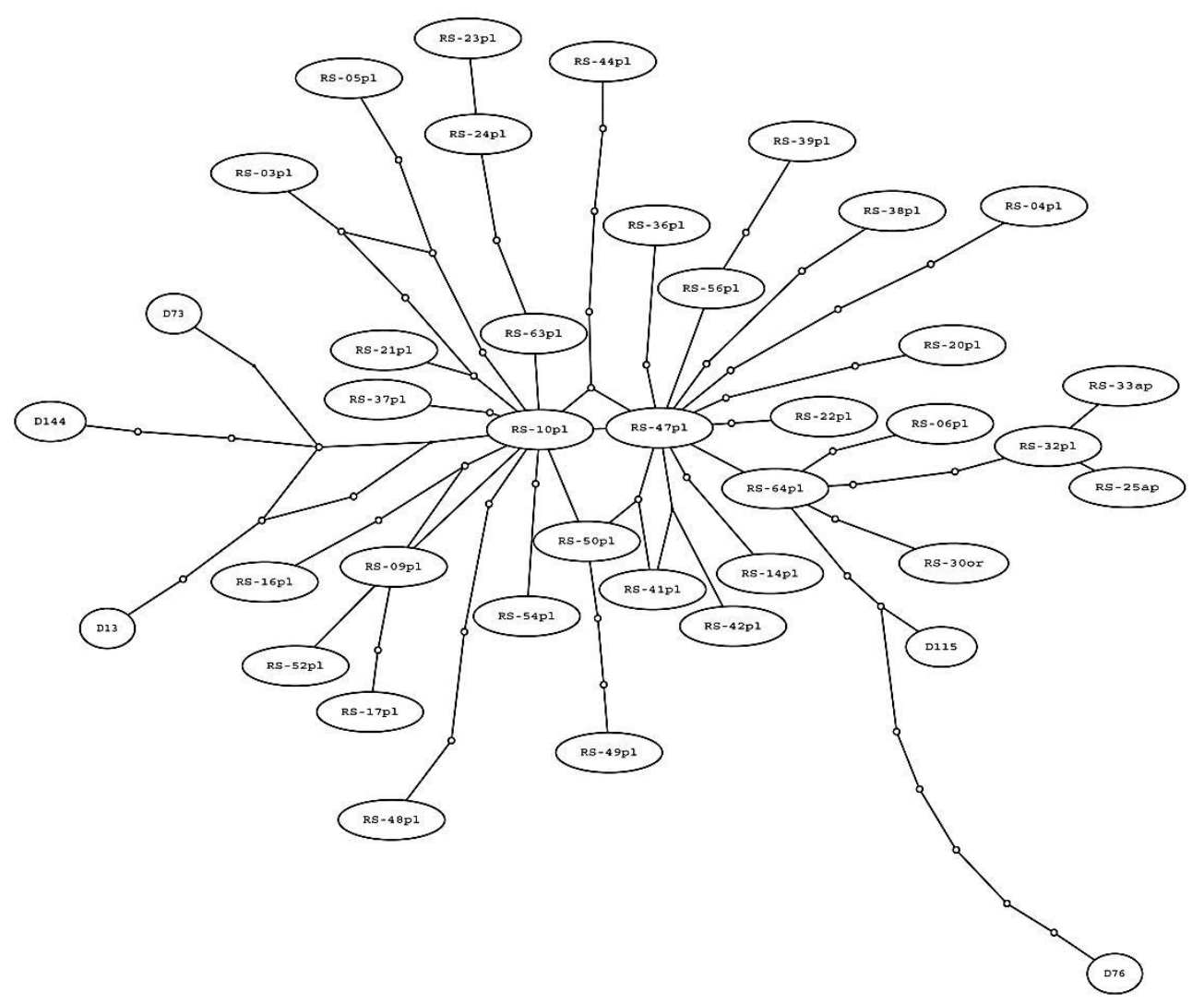

Slika 25. Mreža genealoške povezanosti sekvenci 46 PPV-Rec izolata. Svaka linija predstavlja pojedinačnu mutaciju (zamenu nukleotida). Dužine linija nisu signifikantne. Krugovi (०) predstavljaju intermedijarne sekvence izolata koje nisu prisutne u uzorcima.

Sekvence izolata iz Srbije su upoređene sa dostupnim sekvencama PPV-Rec i PPV-D izolata iz drugih zemalja sveta. Zbog velikog broja analiziranih izolata i radi bolje preglednosti, filogenetska analiza je posebno sprovedena za PPV-Rec, a posebno za PPV-D izolate.

Nukleotidne sekvence PPV-Rec izolata su međusobno upoređene i rekonstruisano je filogenetsko stablo na bazi NIb-N-ter CP sekvenci 206 izolata (Slika 26). Radi određivanja diverziteta izolata posebno je određena vrednost genetičke udaljenosti: $a$ ) za svih 206 PPV-Rec izolata; b) za 46 izolata iz Srbije; i $c$ ) za 160 izolata iz ostalih zemalja (Tabela 12). 


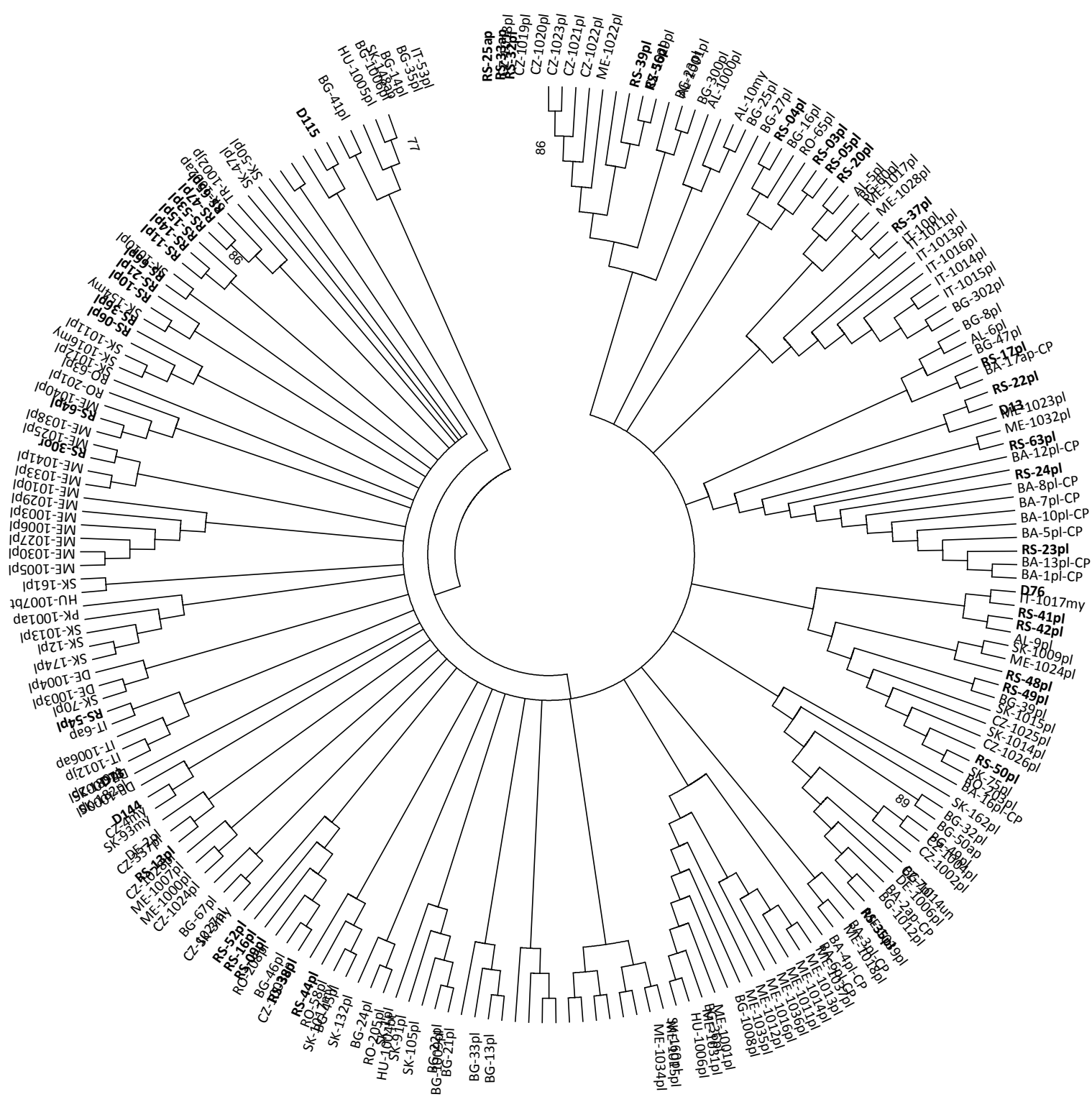

Slika 26. Filogenetsko stablo rekonstruisano iz 447 bp fragmenta 206 PPV-Rec izolata. Izolati iz Srbije su boldirani. Prikazane su bootstrap vrednosti $>75 \%$.

Tabela 12. Vrednosti genetičke udaljenosti različitih grupa PPV-Rec izolata

\begin{tabular}{lll}
\hline$a$ & PPV-Rec (svih 206 izolata) & $\mathbf{0 , 0 2 1} \pm 0,003$ \\
$b$ & PPV-Rec (Srbija, 46 izolata) & $\mathbf{0 , 0 1 8} \pm 0,003$ \\
$c$ & PPV-Rec (ostale zemlje, 160 izolata) & $\mathbf{0 , 0 2 2} \pm 0,004$ \\
\hline
\end{tabular}

U filogenetsku analizu PPV-D izolata uključeno je 348 izolata iz 26 zemalja i 22 izolata iz Srbije, što ukupno čini 370 izolata. Rekonstruisano filogenetsko stablo 
iz fragmenta lociranog u NIb-N-ter CP regionu genoma stablo dato je na slici 27 .

Procenjene vrednosti genetičkog diverziteta su date u tabeli 13.

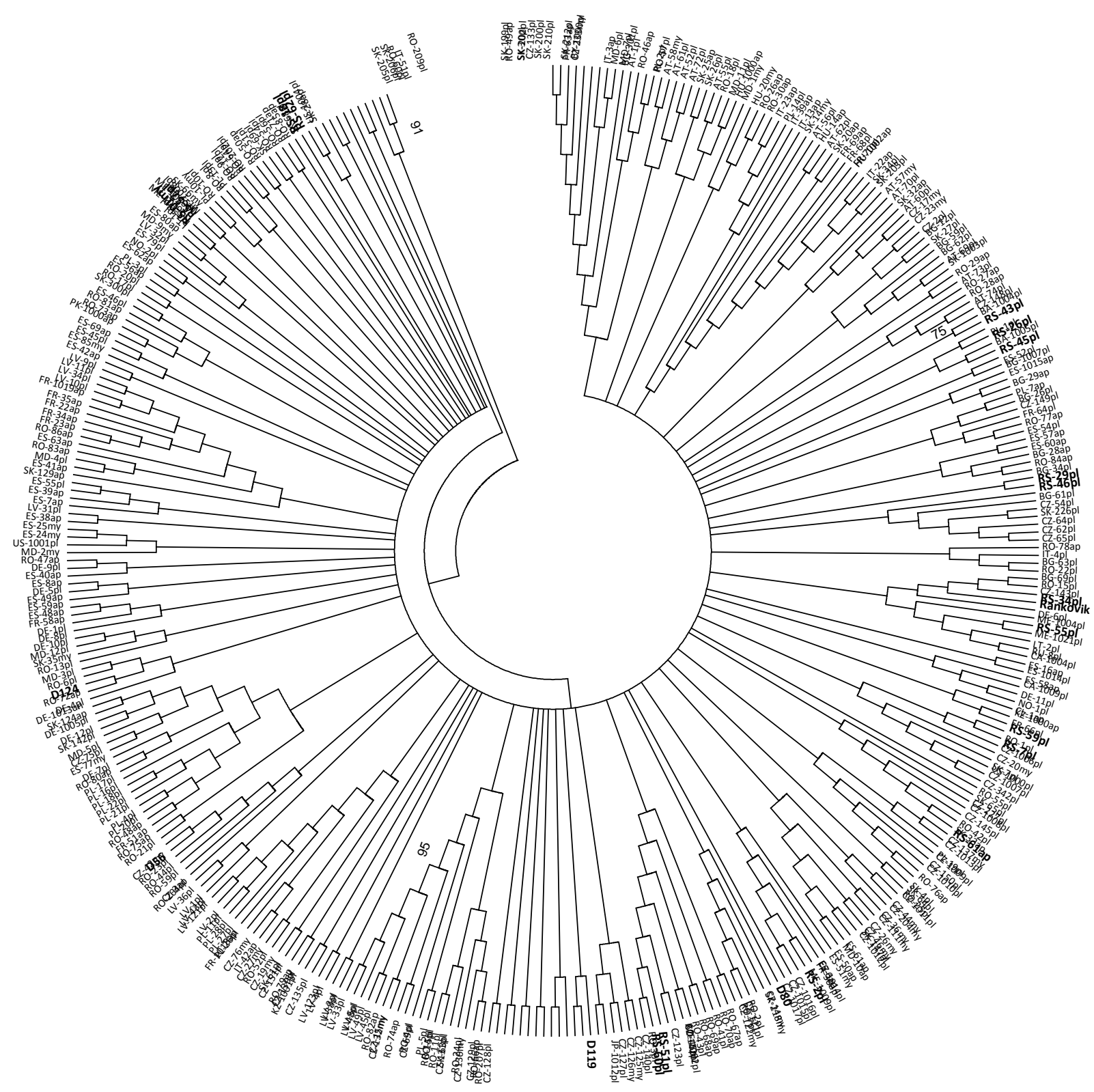

Slika 27. Filogenetsko stablo rekonstruisano iz 447 bp fragmenta 369 PPV-D izolata. Izolati iz Srbije su boldirani. Prikazane su bootstrap vrednosti $>75 \%$.

Tabela 13. Vrednosti genetičke udaljenosti različitih grupa PPV-D izolata

\begin{tabular}{ll}
\hline PPV-D (svih 370 izolata) & $\mathbf{0 , 0 3 1} \pm 0,006$ \\
PPV-D (Srbija, 22 izolata) & $\mathbf{0 , 0 2 7} \pm 0,006$ \\
PPV-D (ostale zemlje, 348 izolata) & $\mathbf{0 , 0 3 1} \pm 0,006$ \\
\hline
\end{tabular}




\subsubsection{Analiza sekvenci P3-6K1 regiona genoma}

Za sekvencioniranje fragmenta lociranog u P3-6K1 (C-ter P3, 6K1 i N-ter CI) regionu genoma primenjeni su prajmeri PCI-PP3.

Nukleotidne sekvence su deponovane u on-line bazu web sajta projekta SharCo (ID brojevi sekvenci su dati u tabeli 9). Obrada sekvenci je izvršena u programu BioEdit.

Filogenetsko stablo rekonstruisano od nukleotidnih sekvenci C-ter P3, 6K1 i $\mathrm{N}$-ter CI regiona genoma jasno pokazuje tri klastera izolata koji odgovaraju PPV-M, PPV-D i PPV-Rec sojevima (Slika 28). Filogenetska analiza potvrđuje rezultate dobijene IC-RT-PCR analizom odabranih izolata.

Genetička udaljenost izolata je proračunata primenom bootstrap modela varijanse sa Kimura 2-P modelom zamene nukleotida. Vrednosti procenjene genetičke udaljenosti date su u tabeli 14 .

Tabela 14. Vrednosti genetičke udaljenosti 41 izolata unutar i između klastera PPV-M, PPV-D i PPV-Rec izolata

\begin{tabular}{lccc}
\hline & PPV-M & PPV-D & PPV-Rec \\
\hline PPV-M (3 izolata) & $\mathbf{0 , 0 0 6} \pm 0,002$ & $0,153 \pm 0,015$ & $0,156 \pm 0,015$ \\
PPV-D (15 izolata) & & $\mathbf{0 , 0 1 3} \pm 0,002$ & $0,029 \pm 0,004$ \\
PPV-Rec (23 izolata) & & & $\mathbf{0 , 0 2 0} \pm 0,002$ \\
\hline
\end{tabular}

Sekvence dobijene tokom izrade ove disertacije su upoređene sa još 28 sekvenci PPV izolata iz Srbije (Dallot et al., 2011; Jevremović, 2008). Upoređene su sekvence 69 izolata PPV. Rekonstruisano je filogenetsko stablo (Slika 29) i izvršen proračun genetičke udaljenosti svih izolata poreklom iz Srbije (Tabela 15).

Tabela 15. Vrednosti genetičke udaljenosti 69 izolata unutar i između klastera PPV-M, PPV-D i PPV-Rec izolata

\begin{tabular}{lccc}
\hline & PPV-M & PPV-D & PPV-Rec \\
\hline PPV-M (26 izolata) & $\mathbf{0 , 0 0 6} \pm 0,001$ & $0,153 \pm 0,016$ & $0,155 \pm 0,016$ \\
PPV-D (18 izolata) & & $\mathbf{0 , 0 1 5} \pm 0,002$ & $0,030 \pm 0,004$ \\
PPV-Rec (35 izolata) & & & $\mathbf{0 , 0 1 9} \pm 0,002$ \\
\hline
\end{tabular}




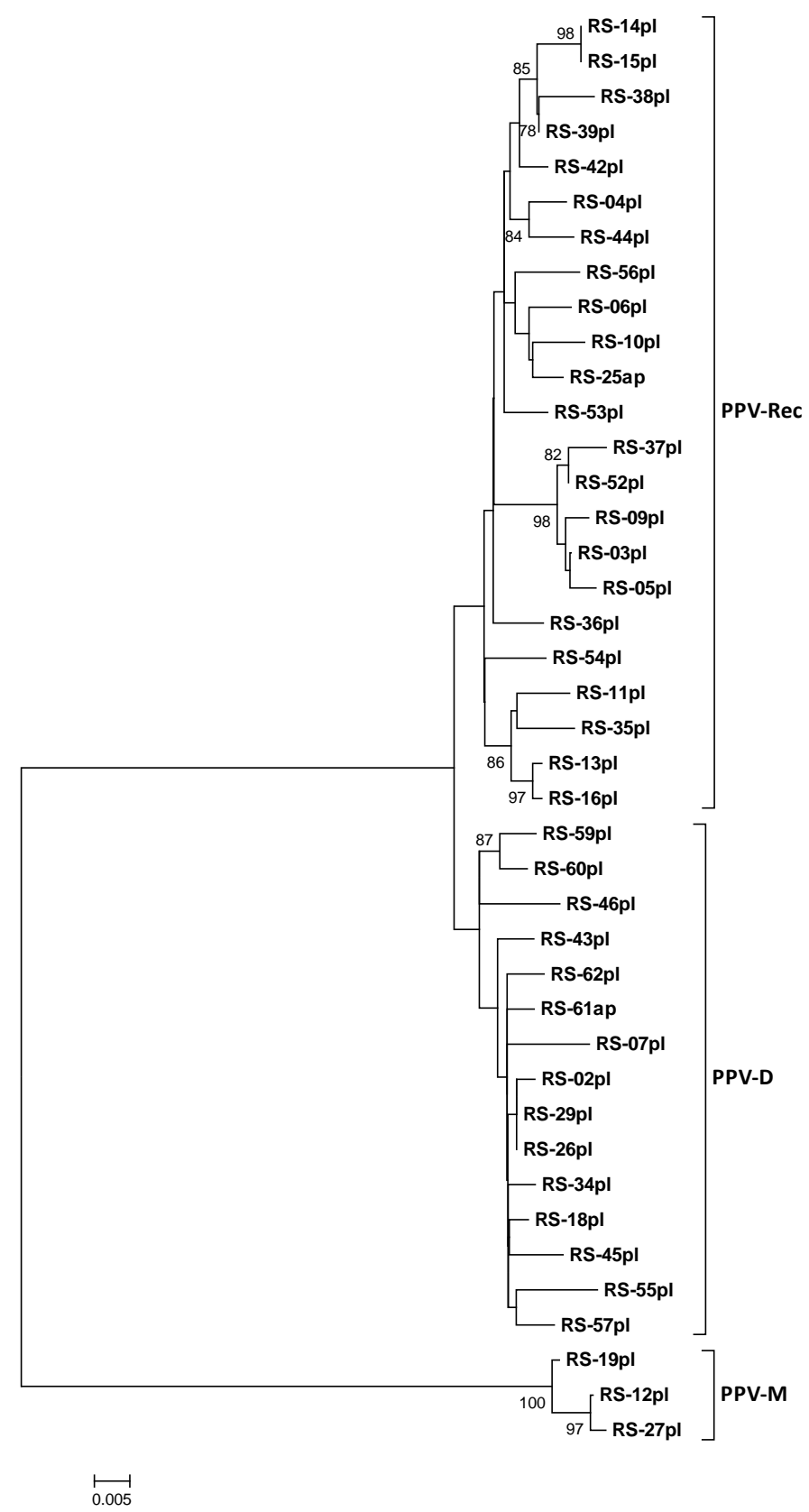

Slika 28. Filogenetsko stablo rekonstruisano iz 788 bp fragmenta 41 PPV izolata. Prikazane su bootstrap vrednosti $>75 \%$. 


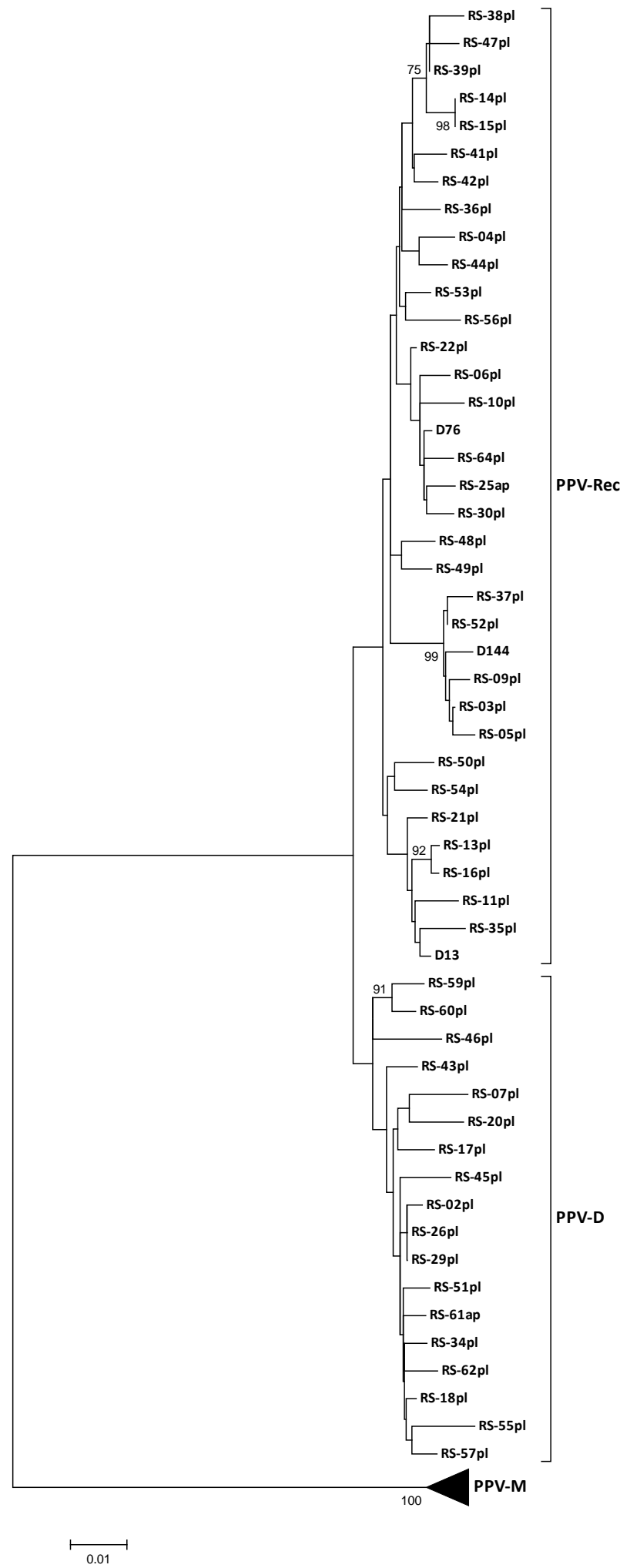

Slika 29. Filogenetsko stablo rekonstruisano iz 788 bp fragmenta 69 PPV izolata. Prikazane su bootstrap vrednosti $>75 \%$. 
Sekvence izolata iz Srbije su upoređene sa dostupnim sekvencama PPV-Rec i PPV-D izolata ovog regiona genoma iz 11 drugih zemalja. Filogenetska analiza je posebno sprovedena za PPV-Rec, a posebno za PPV-D izolate.

Nukleotidne sekvence PPV-Rec izolata su međusobno upoređene i rekonstruisano je filogenetsko stablo na bazi P3-6K1 sekvenci 131 izolata (Slika 30). Radi određivanja diverziteta izolata posebno je određena vrednost genetičke udaljenosti: a) za svih 131 PPV-Rec izolata; b) za 36 izolata iz Srbije; i c) za 95 izolata iz ostalih zemalja. Za sve tri grupe izolata $(a, b$ i $c)$ vrednost genetičkog diverziteta je $0,018 \pm 0,002$.

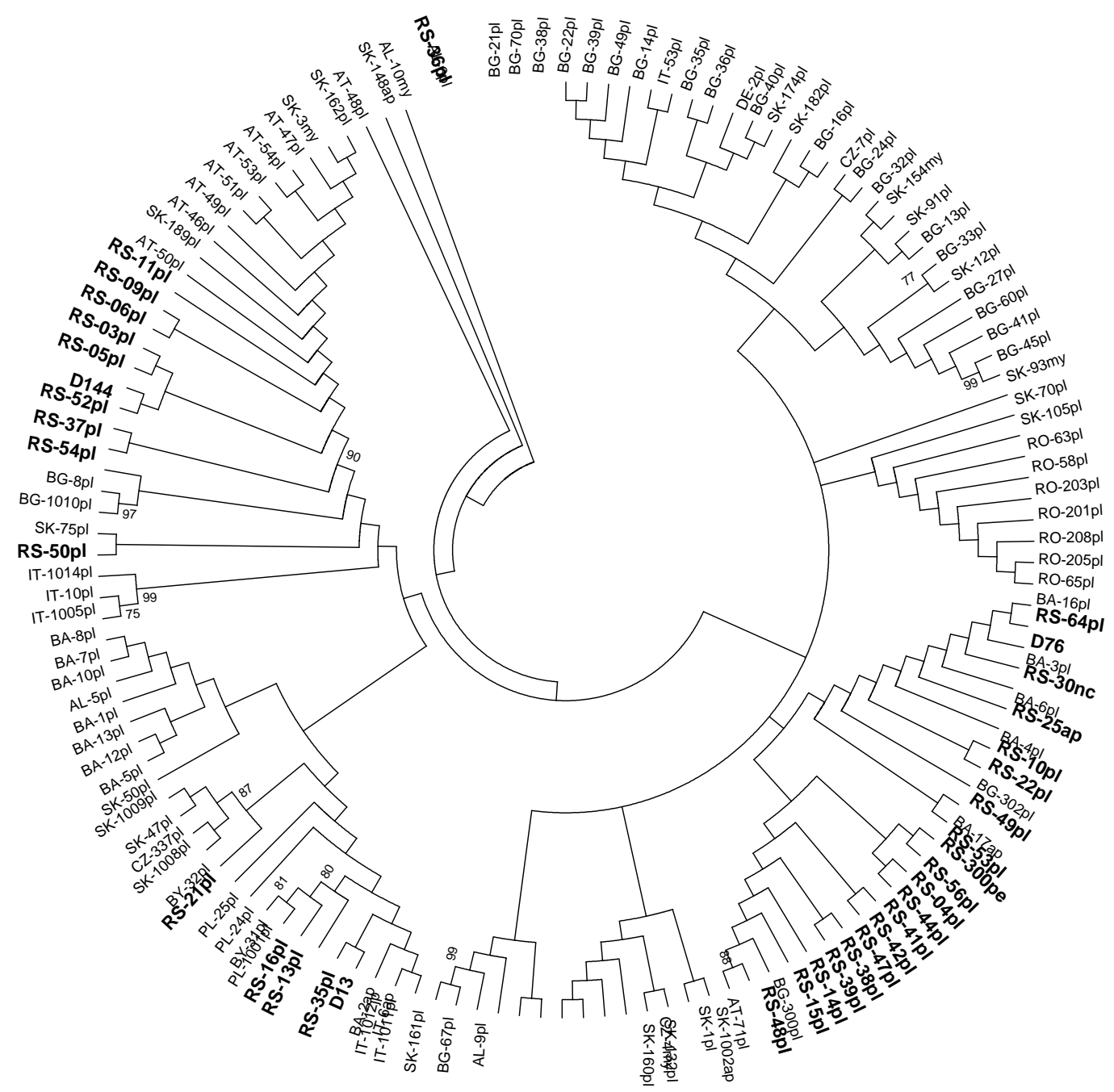

Slika 30. Filogenetsko stablo rekonstruisano iz 723 bp fragmenta 131 PPV-Rec izolata Izolati iz Srbije su boldirani. Prikazane su bootstrap vrednosti $>75 \%$. 
U filogenetsku analizu PPV-D izolata uključeno je 206 izolata iz 24 zemalja i 18 izolata iz Srbije, što ukupno čini 224 izolata. Rekonstruisano filogenetsko stablo iz fragmenta lociranog u P3-6K1 regionu genoma stablo dato je na slici 31 . Posebno je određena vrednost genetičke udaljenosti: a) za svih 224 PPV-D izolata; b) za 18 izolata iz Srbije; i $c$ ) za 206 izolata iz ostalih zemalja. Za $b$ i $c$ grupu izolata vrednost genetičkog diverziteta je $0,014 \pm 0,002$, dok za grupu a iznosi $0,015 \pm 0,002$.

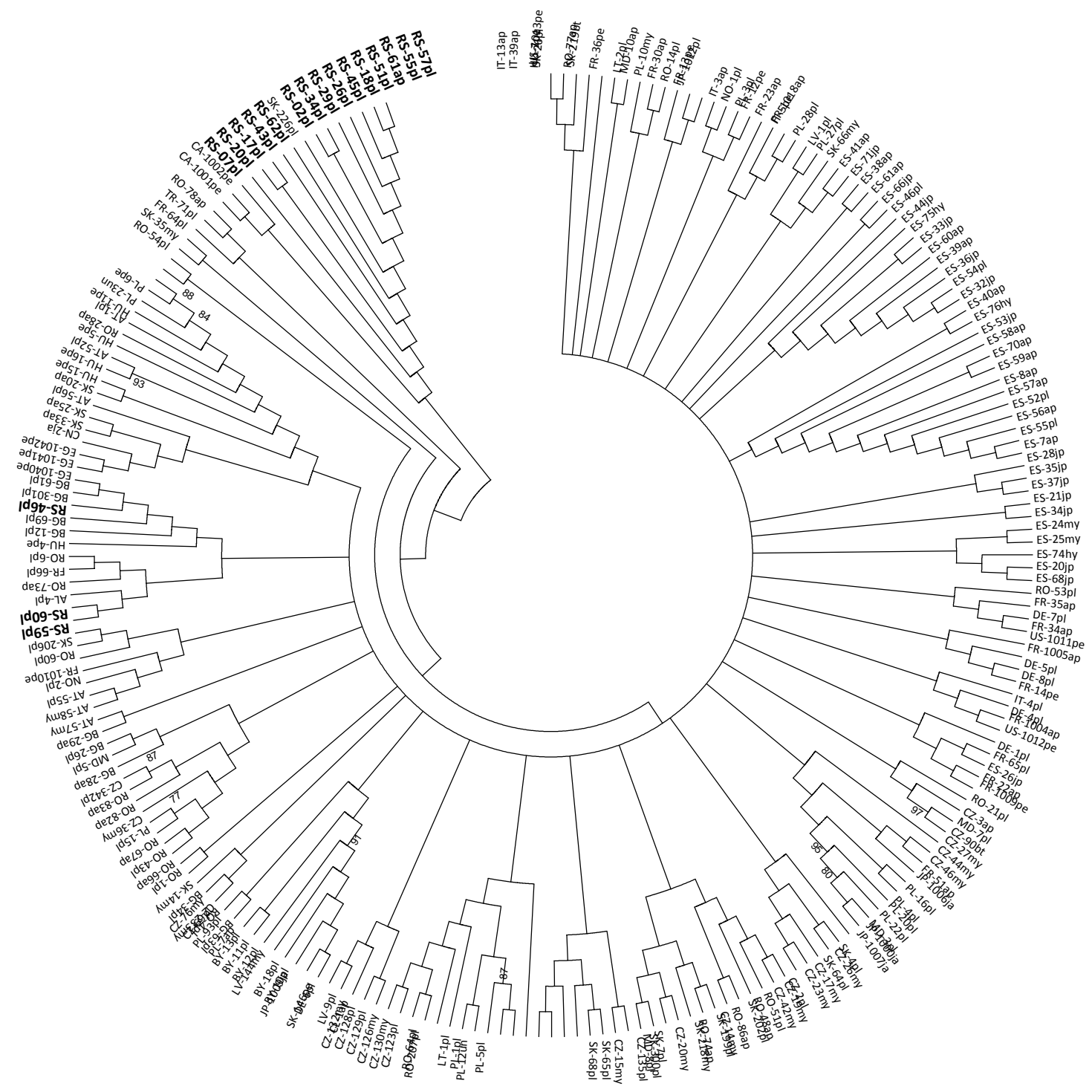

Slika 31. Filogenetsko stablo rekonstruisano iz 723 bp fragmenta 224 PPV-D izolata Izolati iz Srbije su boldirani. Prikazane su bootstrap vrednosti $>75 \%$. 


\subsection{Dinamika širenja sojeva šarke šljive, prisustvo $i$ brojnost lisnih vaši u eksperimentalnom zasadu šljive}

\subsubsection{Ispitivanja prisustva virusa šarke $u$ eksperimentalnom zasadu u prvoj godini istraživanja (2008. godina)}

Nakon sadnje i prijema sadnica izvršen je vizuelni pregled prvih listova tokom prve dekade juna. Prilikom pregleda nije utvrđeno nijedna biljka šljive sa simptomima koji mogu ukazivati na prisustvo virusa šarke.

Radi provere zdravstvenog statusa, sve biljke su DAS-ELISA testom ispitane na prisustvo PPV. ELISA testom ni u jednoj biljci nije utvrđeno prisustvo PPV.

U fazi pripreme za podizanje eksperimentalnog zasada šljive tokom prethodne godine (2007.) izvršen je vizuelni pregled terena oko zasada. U malom zasadu šljive sorte Stenley koji se nalazi u blizini eksperimentalnog zasada izvršen je vizuelni pregled svih stabala i uzeti su uzorci za ELISA test (Šema 2). Od ukupno 38 stabala u zasadu, kod 11 je potvrđeno prisustvo PPV. Radi tipiziranja izolata u pozitivnim uzorcima sproveden je IC-RT-PCR test. Rezultati analize su prikazani u tabeli 16.

Od 11 stabala šljive, kod 8 je utvrđen PPV-Rec soj, a kod 3 stabla PPV-D soj. Svi izolati su sekvencionirani u C-ter NIb-N-ter CP regionu genoma radi kasnijeg upoređivanja sa sekvencama izolata iz eksperimentalnog zasada.

Osim zaraženih stabala iz malog zasada šljive, utvrđena su i dva stabla šljive sorte Crvena ranka koja se nalaze oko $40 \mathrm{~m}$ od eksperimentalnog zasada u pravcu jugoistok. Sa ovih stabala su uzeti uzorci listova i izvršeno je tipiziranje izolata PPV IC-RT-PCR metodom. Utvrđeno je da je u oba stabla prisutan PPV-Rec soj i oba izolata su sekvencionirana u C-ter NIb-N-ter CP regionu (Tabela 16). 
Tabela 16. Rezultati tipiziranja izolata PPV iz okoline eksperimentalnog zasada

\begin{tabular}{|c|c|c|c|c|c|c|c|c|}
\hline \multirow[b]{3}{*}{ Broj } & \multirow[b]{3}{*}{$\begin{array}{c}\text { Pozicija } \\
\text { stabla }^{a}\end{array}$} & \multicolumn{7}{|c|}{ REZULTATI PCR ANALIZA } \\
\hline & & \multicolumn{3}{|c|}{ N-ter CP } & \multicolumn{2}{|c|}{ CI } & & \multirow[b]{2}{*}{$\begin{array}{c}\text { Oznaka } \\
\text { sekvence }\end{array}$} \\
\hline & & Sorta & P4-P3M & P4-P3D & CIP-M & CIP-D & Soj & \\
\hline 1 & $2 / 12$ & Stenley & + & - & - & + & Rec & 2/12exter \\
\hline 2 & $2 / 8$ & Stenley & + & - & - & + & Rec & 2/8exter \\
\hline 3 & $2 / 1$ & Stenley & + & - & - & + & Rec & 2/1exter \\
\hline 4 & $3 / 9$ & Stenley & + & - & - & + & Rec & $3 / 9$ exter \\
\hline 5 & $4 / 13$ & Stenley & + & - & - & + & Rec & 4/13exter \\
\hline 6 & $4 / 12$ & Stenley & - & + & - & + & D & 4/12exter \\
\hline 7 & $4 / 11$ & Stenley & + & - & - & + & $\operatorname{Rec}$ & 4/11exter \\
\hline 8 & $4 / 9$ & Stenley & - & + & - & + & D & 4/9exter \\
\hline 9 & $4 / 4$ & Stenley & - & + & - & + & D & 4/4exter \\
\hline 10 & $4 / 3$ & Stenley & + & - & - & + & Rec & 4/3exter \\
\hline 11 & $4 / 2$ & Stenley & + & - & - & + & Rec & 4/2exter \\
\hline 12 & / & Crvena ranka & + & - & - & + & $\operatorname{Rec}$ & RS-23pl \\
\hline 13 & 1 & Crvena ranka & + & - & - & + & Rec & RS-24-pl \\
\hline
\end{tabular}

${ }^{\text {a }}$ broj reda/broj stabla u redu

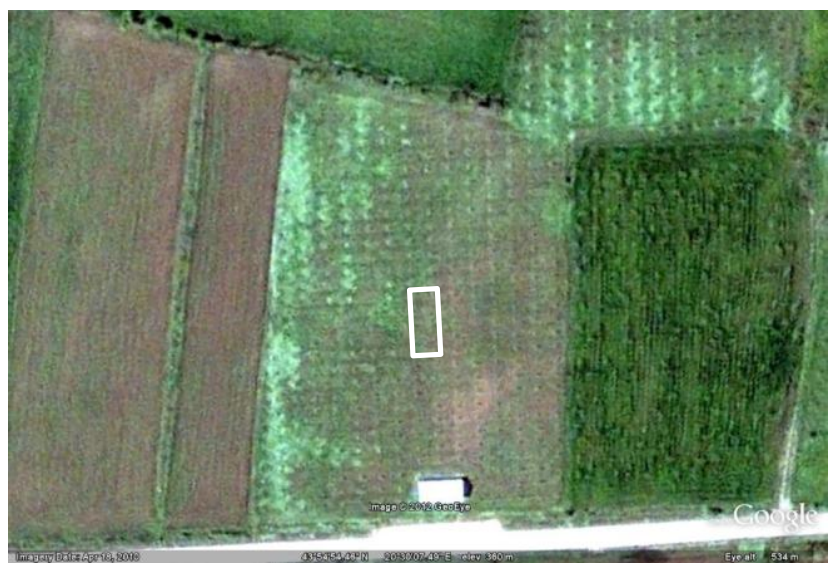

$\begin{array}{lllll}13 & & \circ & \circ & \bullet \\ 12 & & \bullet & \circ & \bullet \\ 11 & & \circ & \circ & \bullet \\ 10 & & \circ & \circ & \\ 9 & & \circ & \bullet & \bullet \\ 8 & & \bullet & \circ & \circ \\ 7 & & \circ & \circ & \circ \\ 6 & & \circ & \circ & \circ \\ 5 & & \circ & \circ & \circ \\ 4 & & \circ & \circ & \bullet \\ 3 & & \circ & \circ & \bullet \\ 2 & & \circ & \circ & \bullet \\ 1 & \circ & \bullet & \circ & \circ \\ & 1 & 2 & 3 & 4\end{array}$

Slika 32. Pozicija inokulisanih sadnica u eksperimentalnom zasadu šljive (označeno belom linijom)
Šema 2. Mapa malog zasada šljive $(\bullet-$ zaražena stabla)

U trećoj dekadi juna meseca izvršena je inokulacija 8 posađenih sadnica šljive koja su locirana na sredini zasada (Šema 1 i slika 32). Inokulacija je urađena metodom chip-budding sa po 2 čipa po sadnici. Četiri stabla su inokulisana PPV-Rec izolatom RS-67pl. Pozicije inokulisanih stabala su 9/13, 9/15, 10/14 i 10/16 (broj reda /broj stabla u redu). PPV-D izolatom RS-68pl inokulisana su 4 stabla na pozicijama 9/14, 9/16, 10/13 i 10/15. Izolati za inokulaciju su odabrani iz kolekcije PPV-D i PPV-Rec izolata (potencijalnih inokuluma) na osnovu rezultata upoređivanja sekvenci $\mathrm{C}$-ter $\mathrm{NIb}-\mathrm{N}$-ter $\mathrm{CP}$ regiona ovih izolata sa sekvencama izolata koji su detektovani u obližnjem malom zasadu šljive i izolatima sa stabala Crvene ranke. Upoređivanjem sekvenci $\mathrm{C}$-ter $\mathrm{NIb}-\mathrm{N}$-ter $\mathrm{CP}$ regiona u programu 
BioEdit utvrđeno je da se odabrani PPV-Rec izolat RS-67pl razlikuje od svih ostalih PPV-Rec izolata iz neposredne okoline eksperimentalnog zasada u 2 fiksne mutacije (nukleotida). Pozicije odgovarajućih nukleotida su date u tabeli 17. Sekvence su date u prilogu 2.

Tabela 17. Lista pozicija i odgovarajuće nukleotidne promene između izolata RS-67pl i ostalih ispitivanih PPV-Rec izolata

\begin{tabular}{cccc}
\hline Pozicija nukleotida $^{\mathbf{a}}$ & Pozicija nukleotida $^{\mathbf{b}}$ & RS-67-pl $^{-}$ & Ostali izolati $^{-}$ \\
\hline 8648 & 183 & $\mathrm{~A}$ & $\mathrm{~T}$ \\
8653 & 188 & $\mathrm{~T}$ & $\mathrm{C}$ \\
\hline
\end{tabular}

aPozicija prema sekvenci kompletnog genoma izolata RS-67pl

bPozicija prema sekvenci 427 bp fragmenta izolata RS-67pl

Sekvenca C-ter NIb-N-ter CP regiona genoma PPV-D izolata RS-68pl razlikuje se od svih ostalih PPV-D izolata iz neposredne okoline eksperimentalnog zasada u 5 fiksnih mutacija (nukleotida). Pozicije odgovarajućih nukleotida su date u tabeli 18. Sekvence su date u prilogu 3.

Tabela 18. Lista pozicija i odgovarajuće nukleotidne promene između izolata RS-68pl i ostalih ispitivanih PPV-D izolata

\begin{tabular}{cccc}
\hline Pozicija nukleotidac $^{\mathbf{c}}$ & Pozicija nukleotida $^{\mathbf{d}}$ & RS-68-pl & Ostali izolati $^{-}$ \\
\hline 8486 & 21 & $\mathrm{~T}$ & $\mathrm{G}$ \\
8541 & 76 & $\mathrm{~A}$ & $\mathrm{G}$ \\
8621 & 156 & $\mathrm{~T}$ & $\mathrm{G}$ \\
8622 & 157 & $\mathrm{G}$ & $\mathrm{A}$ \\
$\mathrm{8} 243$ & 378 & $\mathrm{C}$ & $\mathrm{T}$ \\
\hline
\end{tabular}

cPozicija prema sekvenci kompletnog genoma izolata RS-68pl

dPozicija prema sekvenci 427 bp fragmenta izolata RS-68pl

Istraživanja epidemioloških osobina odabranih izolata koja su sprovedena u Francuskoj su pokazala visoku efikasnost prenošenja oba izolata na šljivu, kajsiju i breskvu lisnim vašima Myzus persicae Sulz. (Gerard Labonne i Sylvie Dallot, lična komunikacija).

Dve nedelje po inokulaciji izvršena je provera prijema kalemljenja i utvrđeno je da je kalemljenje bilo uspešno. Do kraja vegetacije 2008. godine izvršena su još dva vizuelna pregleda svih stabala šljive u eksperimentalnom zasadu. Tokom pregleda nisu utvrđena stabla sa simptomima prisustva virusa šarke. 


\subsubsection{Ispitivanja prisustva virusa šarke u eksperimentalnom zasadu u drugoj godini istraživanja (2009. godina)}

\section{Vizuelni pregledi}

U eksperimentalnom zasadu je u prvoj dekadi juna 2009. godine sproveden vizuelni pregled svih stabala šljive. Prilikom pregleda su, osim na svih 8 inokulisanih, na još 3 stabla šljive uočeni simptomi virusa šarke. Ocena simptoma je data u tabeli 19.

Tabela 19. Opisni rezultati vizuelnog pregleda stabala šljive u eksperimentalnom zasadu tokom 2009. godine

\begin{tabular}{ccccc}
\hline Broj & Pozicija & $\begin{array}{c}\text { Ocena } \\
\text { simptoma }\end{array}$ & $\begin{array}{c}\text { Intenzitet } \\
\text { Izgled simptoma }\end{array}$ & $\begin{array}{c}\text { simptoma } \\
\text { simpor }\end{array}$ \\
\hline 1 & $\mathbf{3 / 3}$ & 2 & Mo, PP & 3 \\
2 & $\mathbf{1 2 / 7}$ & 2 & Mo, PP & 3 \\
3 & $\mathbf{1 5 / 7}$ & 3 & Mo, PP & 2 \\
4 & $9 / 13$ & 2 & Mo, PP & 3 \\
5 & $9 / 14$ & 2 & Mo, PP & 3 \\
6 & $9 / 15$ & 3 & Mo, PP & 3 \\
\hline 7 & $9 / 16$ & 2 & Mo, PP & 3 \\
\hline 8 & $10 / 13$ & 2 & Mo, PP & 3 \\
\hline 9 & $10 / 14$ & 2 & Mo, PP & 2 \\
\hline 10 & $10 / 15$ & 2 & Mo, PP & 3 \\
\hline 11 & $10 / 16$ & 3 & & \\
\hline
\end{tabular}

Na stablima 3/3, 12/7 i 15/7 su uočeni izraženi simptomi šarke u vidu mozaika i prstenastih pega, uglavnom na nekoliko grančica na jednoj skeletnoj grani.

$\mathrm{Na}$ inokulisanim stablima su simptomi bili ujednačeno izraženi na po nekoliko grančica na jednoj skeletnoj grani u vidi mozaika i prstenastih pega.

Tokom jula i avgusta 2009. godine ponovljeni su vizuelni pregledi u kojima nisu utvrđena nova stabla sa simptomima šarke.

\section{ELISA test}

U prvoj dekadi jula 2009. godine ELISA testom su sva stabla šljive u eksperimentlnom zasadu ispitana na prisustvo virusa šarke šljive. Od svih analiziranih stabala virus šarke je, pored inokulisanih stabala, potvrđen i kod stabala $3 / 3,12 / 7$ i 15/7. Rezultati ELISA testa su u saglasnosti sa vizuelnim pregledima, jer je kod svih stabala sa simptomima potvrđeno prisustvo PPV. 


\section{IC-RT-PCR}

Radi utvrđivanja soja PPV prisutnog u uzorcima koji su dali pozitivnu reakciju u ELISA testu, sproveden je IC-RT-PCR test. Analiza je pokazala da je u stablu 3/3 prisutan PPV-D soj, a u stablima 12/7 i 15/7 PPV-Rec soj (Tabela 20, šema 3). Kod inokulisanih stabala tipiziranje je dalo očekivane rezultate saglasno inokulaciji odgovarajućim izolatom.

Tabela 20. Rezultati tipiziranja PPV izolata iz eksperimentalnog zasada

\begin{tabular}{|c|c|c|c|c|c|c|c|}
\hline \multicolumn{8}{|c|}{ REZULTATI PCR ANALIZA } \\
\hline \multirow[b]{2}{*}{ Broj } & \multirow[b]{2}{*}{$\begin{array}{c}\text { Pozicija } \\
\text { stabla }\end{array}$} & \multicolumn{2}{|c|}{ N-ter CP } & \multicolumn{2}{|c|}{ CI } & \multirow[b]{2}{*}{ Soj } & \multirow[b]{2}{*}{$\begin{array}{l}\text { Oznaka } \\
\text { sekvence }\end{array}$} \\
\hline & & P4-P3M & P4-P3D & CIP-M & CIP-D & & \\
\hline 1 & $3 / 3$ & - & + & - & + & D & 3/3_09 \\
\hline 2 & $12 / 7$ & + & - & - & + & Rec & 12/7_09 \\
\hline 3 & $15 / 7$ & + & - & - & + & Rec & 15/7_09 \\
\hline 4 & $9 / 13$ & + & - & - & + & $\operatorname{Rec}$ & $9 / 13$ \\
\hline 5 & $9 / 14$ & - & + & - & + & $\mathrm{D}$ & $9 / 14$ \\
\hline 6 & $9 / 15$ & + & - & - & + & $\operatorname{Rec}$ & $9 / 15$ \\
\hline 7 & $9 / 16$ & - & + & - & + & $\mathrm{D}$ & $9 / 16$ \\
\hline 8 & $10 / 13$ & - & + & - & + & $\mathrm{D}$ & $10 / 13$ \\
\hline 9 & $10 / 14$ & + & - & - & + & $\operatorname{Rec}$ & $10 / 14$ \\
\hline 10 & $10 / 15$ & - & + & - & + & $\mathrm{D}$ & $10 / 15$ \\
\hline 11 & $10 / 16$ & + & - & - & + & $\operatorname{Rec}$ & $10 / 6$ \\
\hline
\end{tabular}

\section{Sekvencioniranje}

Svi pozitivni uzorci (Tabela 20) su dalje analizirani sekvencioniranjem C-ter NIb-N-ter CP regiona genoma. Sekvence PPV-Rec i PPV-D izolata su date u prilozima 4 i 5. Kod svih stabala inokulisanih PPV-D izolatom RS-68pl, na poziciji 204 je C umesto T, koji je prisutan kod inokuluma RS-68pl (Prilog 5). Ova mutacija nije od značaja u daljoj analizi.

\section{TCS analiza}

Genealoška povezanost izolata koji su potvrđeni $\mathrm{u}$ eksperimentalnom zasadu, izolata sa inokulisanih stabala i izolata iz neposredne okoline izvršena je TCS analizom. Na slikama 33 i 34 date su mreže rodoslovne povezanosti sekvenci C-ter NIb-N-ter CP regiona PPV-D i PPV-Rec izolata.

TCS analiza ilustrativno pokazuje da zaražena stabla šljive iz eksperimentalnog zasada koja su detektovana u 2009. godini nisu zaražena izolatom sa inokulisanih stabala.

Sekvence dva PPV-Rec izolata $12 / 7$ i 15/7 takođe pokazuju znatnu divergentnost $\mathrm{u}$ odnosu na izolat sa inokulisanih stabala (10 i 12 nt razlike). 
Međutim, sekvence ova dva izolata pokazuju veliku sličnost (3 i 1 nt razlike) sa sekvencama izolata iz neposredne okoline eksperimentalnog zasada (4/2exter, 4/11exter i RS-24pl) (slika 33). PPV-D izolat sa stabla 3/3 pokazuje veliku divergentnost u odnosu na izolat sa inokulisanih stabala (13 nt razlike), kao i u odnosu na PPV-D izolate iz obližnjeg zasada (19 nt razlike) (slika 34).

\begin{tabular}{|c|c|c|c|c|c|c|c|c|c|c|c|c|c|c|c|c|}
\hline 29 & & & & $\circ$ & $\circ$ & ० & ० & 0 & $\circ$ & & & & & & & \\
\hline 28 & & & & 0 & 0 & 0 & 0 & 0 & 0 & ○ & 0 & 0 & & & & \\
\hline 27 & & & & 0 & ० & ○ & o & ० & ० & ○ & 0 & 0 & ० & 0 & 0 & o \\
\hline 26 & & & & 0 & 0 & 0 & ० & 0 & 0 & 0 & 0 & 0 & 0 & 0 & $\circ$ & o \\
\hline 25 & & & & O & ० & ० & o & 0 & o & ० & 0 & ० & 0 & 0 & o & o \\
\hline 24 & & & o & O & ○ & 0 & o & $\circ$ & 0 & 0 & 0 & 0 & 0 & 0 & o & ○ \\
\hline 23 & & & o & 0 & ० & 0 & o & 0 & 0 & 0 & 0 & 0 & 0 & 0 & O & ० \\
\hline 22 & & & $\circ$ & 0 & 0 & 0 & o & 0 & 0 & 0 & 0 & 0 & 0 & 0 & o & O \\
\hline 21 & & & 0 & 0 & 0 & 0 & 0 & 0 & 0 & 0 & 0 & 0 & 0 & 0 & $\circ$ & ० \\
\hline 20 & & & o & 0 & 0 & 0 & 0 & 0 & 0 & 0 & 0 & 0 & 0 & 0 & $\circ$ & ० \\
\hline 19 & & & o & 0 & 0 & 0 & o & 0 & 0 & 0 & 0 & 0 & 0 & 0 & o & o \\
\hline 18 & & & $\circ$ & $\circ$ & 0 & $\circ$ & ० & $\circ$ & 0 & 0 & 0 & 0 & 0 & 0 & 0 & 0 \\
\hline 17 & & & 0 & 0 & 0 & 0 & o & 0 & 0 & 0 & 0 & 0 & 0 & 0 & $\circ$ & o \\
\hline 16 & & & o & ○ & ○ & $\circ$ & ० & ○ & • & $\bullet$ & 0 & ० & ० & o & o & ○ \\
\hline 15 & & & o & ० & $\circ$ & 0 & o & 0 & $\bullet$ & • & 0 & 0 & 0 & 0 & o & o \\
\hline 14 & & & 0 & 0 & $\circ$ & $\circ$ & 0 & 0 & • & $\bullet$ & 0 & 0 & 0 & $\circ$ & $\circ$ & o \\
\hline 13 & & & o & ० & 0 & 0 & o & 0 & $\bullet$ & $\bullet$ & 0 & 0 & 0 & 0 & O & ○ \\
\hline 12 & & 0 & o & 0 & O & 0 & o & 0 & 0 & 0 & 0 & 0 & 0 & 0 & o & O \\
\hline 11 & & o & $\circ$ & $\circ$ & 0 & 0 & $\circ$ & $\circ$ & 0 & 0 & 0 & 0 & 0 & o & $\circ$ & 0 \\
\hline 10 & & 0 & 0 & ० & ० & 0 & 0 & 0 & 0 & 0 & 0 & ० & 0 & 0 & 0 & ० \\
\hline 9 & & 0 & o & 0 & 0 & 0 & o & 0 & 0 & 0 & 0 & 0 & 0 & 0 & o & 0 \\
\hline 8 & & 0 & 0 & 0 & 0 & 0 & o & o & 0 & 0 & 0 & 0 & 0 & 0 & O & O \\
\hline 7 & & O & 0 & ० & $\circ$ & 0 & 0 & 0 & $\circ$ & 0 & 0 & $\bullet$ & ० & o & $\bullet$ & o \\
\hline 6 & & $\circ$ & o & 0 & $\circ$ & $\circ$ & o & 0 & 0 & $\circ$ & 0 & 0 & 0 & 0 & o & o \\
\hline 5 & & 0 & o & $\circ$ & 0 & 0 & o & 0 & 0 & 0 & 0 & 0 & 0 & 0 & o & o \\
\hline 4 & & $\circ$ & o & 0 & 0 & 0 & o & 0 & 0 & 0 & 0 & 0 & 0 & 0 & 0 & O \\
\hline 3 & 0 & 0 & $\bullet$ & 0 & 0 & 0 & 0 & 0 & 0 & 0 & 0 & 0 & 0 & 0 & $\circ$ & o \\
\hline 2 & 0 & 0 & 0 & ० & 0 & 0 & 0 & 0 & & & & 0 & 0 & 0 & $\circ$ & o \\
\hline 1 & 0 & 0 & 0 & 0 & 0 & 0 & 0 & & & & & 0 & 0 & O & 0 & o \\
\hline & $\boldsymbol{r}$ & $N$ & $\omega$ & $A$ & $\boldsymbol{U}$ & $a$ & $v$ & $\infty$ & 0 & 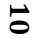 & 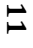 & $\vec{N}$ & $\overleftrightarrow{\omega}$ & $\stackrel{F}{\oplus}$ & $\vec{v}$ & $\vec{a}$ \\
\hline
\end{tabular}

Šema 3. Mapa eksperimentalnog zasada šljive sa pozicijama zaraženih stabala u 2009.

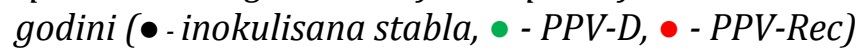




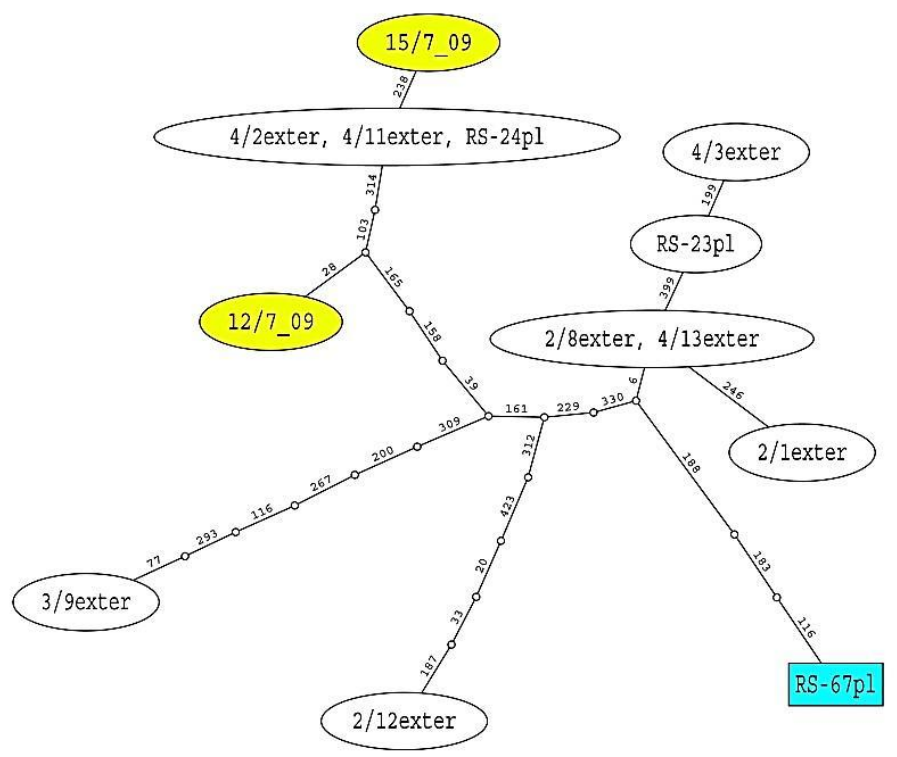

Slika 33. Mreža genealoške povezanosti analiziranih PPV-Rec izolata iz eksperimentalnog zasada (označeni žuto), njegove okoline (označeni belo) i PPV-Rec izolata sa inokulisanih stabala (označen plavo). Svaka linija predstavlja pojedinačnu mutaciju između dva izolata sa pozicijom mutacije. Nedostajuće (hipotetičke) sekvence su predstavljene kružićima.

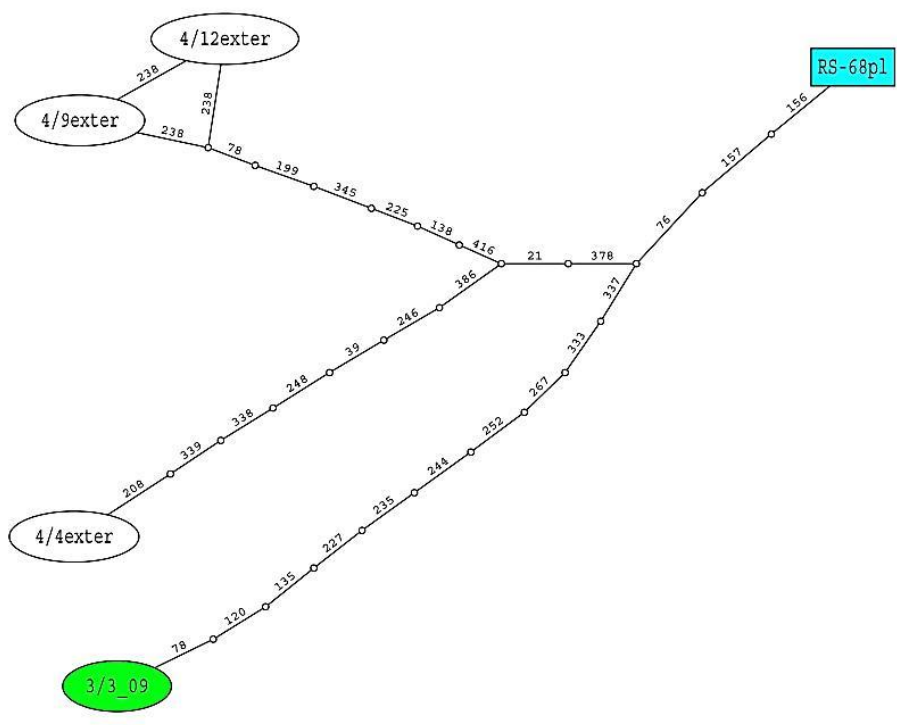

Slika 34. Mreža genealoške povezanosti analiziranih PPV-D izolata iz eksperimentalnog zasada (označeni zeleno), njegove okoline (označeni belo) i PPV-D izolata sa inokulisanih stabala (označen plavo). Svaka linija predstavlja pojedinačnu mutaciju između dva izolata sa pozicijom mutacije. Nedostajuće (hipotetičke) sekvence su predstavljene kružićima. 


\section{Praćenje brojnosti i vrsta biljnih vaši}

Tokom 2009. godine praćenje prisustva vrsta i brojnosti lisnih vaši vršeno je u periodu od 4. maja do 9. oktobra. Tokom ovog perioda, primenom Sticky-shoot metode uhvaćeno je ukupno 708 krilatih jedinki preko 40 vrsta lisnih vaši samo na tretiranim listovima (Prilog 6). Najveća brojnost populacije lisnih vaši u prolećnom periodu bila je od 13-19. maja, dok je jesenji pik bio u periodu od 12-21. septembra (Grafikon 7). Najveći broj uhvaćenih vrsta pripada rodovima: Aphis (34\%), Myzocallis (9\%), Rhopalosiphum (9\%) i Capitophorus (8,5\%). Najveća brojnost vrsta lisnih vaši koje su opisane kao vektori prati trend brojnosti ostalih vrsta, osim u trećoj dekadi juna.

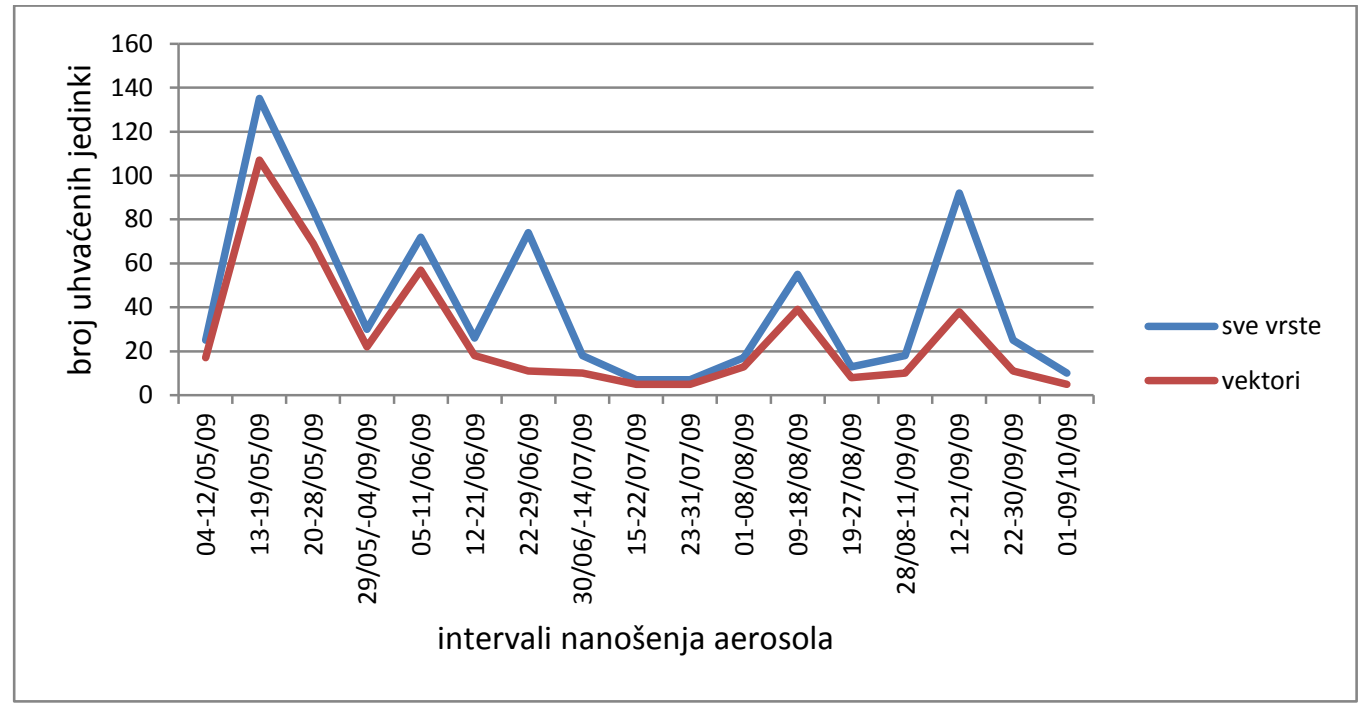

Grafikon 7. Dinamika populacija krilatih formi lisnih vaši uhvaćenih primenom Sticky-shoot metode tokom 2009. godine

\subsubsection{Ispitivanja prisustva virusa šarke $u$ eksperimentalnom zasadu u trećoj godini istraživanja (2010. godina)}

\section{Vizuelni pregledi}

U prvoj dekadi juna 2010. godine sproveden je vizuelni pregled svih stabala šljive u zasadu. Prilikom detaljnog pregleda su, osim na 8 inokulisanih, na još 20 stabala uočeni simptomi virusa šarke šljive. Ocena simptoma je data u tabeli 21. 
$\mathrm{Na} 9$ stabala simptomi su bili prisutni na čitavoj kruni. Na 7 stabala simptomi su uočeni na grančicama jedne skeletne grane, dok su kod 3 stabla simptomi bili prisutni na grančicama dve skeletne grane. Kod stabla 12/18 primećeno je samo par listova sa simptomima. Intenzitet simptoma na stablima je varirao od 2-4, odnosno od blagih do jako izraženih simptoma. Uočeni simptomi na stablima su bili u vidu prstenastih i poluprstenastih pega i mozaika.

$\mathrm{Na}$ svim inokulisanim stablima simptomi su uglavnom bili ujednačeno izraženi na gotovo celoj kruni u vidi mozaika i prstenastih pega. Simptomi su bili izraženi do jako izraženi, osim na stablu 9/13 gde su primećeni blagi simptomi.

Tokom jula i avgusta 2010. godine ponovljeni su vizuelni pregledi u kojima nisu utvrđena nova stabla sa simptomima šarke.

Tabela 21. Opisni rezultati vizuelnog pregleda stabala šljive u eksperimentalnom zasadu

\begin{tabular}{|c|c|c|c|c|}
\hline Broj & $\begin{array}{c}\text { Pozicija } \\
\text { stabla }\end{array}$ & Ocena simptoma & Izgled simptoma & $\begin{array}{l}\text { Intenzitet } \\
\text { simptoma }\end{array}$ \\
\hline 1 & $3 / 3$ & 2 & Mo, PP & 3 \\
\hline 2 & $3 / 21$ & 3 & Mo, PP & 3 \\
\hline 3 & $5 / 2$ & 4 & PP & 2 \\
\hline 4 & $5 / 29$ & 4 & Mo & 3 \\
\hline 5 & $6 / 1$ & 2 & Mo, PP & 3 \\
\hline 6 & $6 / 17$ & 4 & PP & 2 \\
\hline 7 & $6 / 23$ & 4 & PP & 2 \\
\hline 8 & $6 / 27$ & 2 & Mo, PP & 3 \\
\hline 9 & $7 / 1$ & 2 & Mo, PP & 3 \\
\hline 10 & $7 / 20$ & 2 & Mo, PP & 3 \\
\hline 11 & $10 / 11$ & 2 & PP & 4 \\
\hline 12 & $10 / 24$ & 3 & Mo, PP & 4 \\
\hline 13 & $12 / 7$ & 3 & Mo, PP & 3 \\
\hline 14 & $12 / 18$ & 1 & Mo, PP & 3 \\
\hline 15 & $13 / 20$ & 4 & PP & 2 \\
\hline 16 & $14 / 25$ & 2 & Mo, PP & 3 \\
\hline 17 & $15 / 3$ & 4 & $\mathrm{PP}$ & 2 \\
\hline 18 & $15 / 7$ & 4 & Mo, PP & 4 \\
\hline 19 & $15 / 15$ & 4 & Mo, PP & 4 \\
\hline 20 & $16 / 8$ & 4 & PP & 2 \\
\hline 21 & $9 / 13$ & 3 & Mo, PP & 2 \\
\hline 22 & $9 / 14$ & 4 & Mo, PP & 4 \\
\hline 23 & $9 / 15$ & 4 & Mo, PP & 4 \\
\hline 24 & $9 / 16$ & 4 & Mo, PP & 4 \\
\hline 25 & $10 / 13$ & 4 & Mo, PP & 4 \\
\hline 26 & $10 / 14$ & 3 & Mo, PP & 3 \\
\hline 27 & $10 / 15$ & 4 & Mo, PP & 4 \\
\hline 28 & $10 / 16$ & 4 & Mo, PP & 4 \\
\hline
\end{tabular}




\section{ELISA test}

Sva stabla šljive u eksperimentlnom zasadu su sredinom jula 2010. godine ELISA testom ispitana na prisustvo virusa šarke šljive. Od svih analiziranih stabala, virus šarke je utvrđen samo kod stabala koja su pokazivala simptome virusa šarke (Tabela 22). U stablima bez simptoma nije detektovan virus šarke.

\section{IC-RT-PCR}

Svi pozitivni uzorci iz ELISA testa su analizirani IC-RT-PCR metodom (Tabela 22). Analiza je pokazala da je u 2 stabla (3/3 i 3/21) prisutan PPV-D soj, a u 18 stabala $(5 / 2,5 / 29,6 / 1,6 / 17,6 / 23,6 / 27,7 / 1,7 / 20,10 / 11,10 / 24,12 / 7$, 12/18, 13/20, 14/25, 15/3, 15/7, 15/15 i 16/8) PPV-Rec soj (Šema 4). Kod inokulisanih stabala rezultati su potvrdili održavanje pojedinačne infekcije odgovarajućim sojem.

Tabela 22. Rezultati tipiziranja PPV izolata iz eksperimentalnog zasada

\begin{tabular}{|c|c|c|c|c|c|c|c|}
\hline \multirow[b]{3}{*}{ Broj } & \multicolumn{7}{|c|}{ REZULTATI PCR ANALIZA } \\
\hline & \multicolumn{3}{|c|}{ N-ter CP } & \multicolumn{2}{|c|}{ CI } & \multirow[b]{2}{*}{ Soj } & \multirow[b]{2}{*}{$\begin{array}{c}\text { Oznaka } \\
\text { sekvence }\end{array}$} \\
\hline & Pozicija stabla & P4-P3M & P4-P3D & CIP-M & CIP-D & & \\
\hline 1 & $3 / 3$ & - & + & - & + & D & 3/3_10 \\
\hline 2 & $3 / 21$ & - & + & - & + & D & 3/21_10 \\
\hline 3 & $5 / 2$ & + & - & - & + & Rec & 5/2_10 \\
\hline 4 & $5 / 29$ & + & - & - & + & Rec & 5/29_10 \\
\hline 5 & $6 / 1$ & + & - & - & + & Rec & 6/1_10 \\
\hline 6 & $6 / 17$ & + & - & - & + & Rec & 6/17_10 \\
\hline 7 & $6 / 23$ & + & - & - & + & Rec & 6/23_10 \\
\hline 8 & $6 / 27$ & + & - & - & + & Rec & $6 / 27 \_10$ \\
\hline 9 & $7 / 1$ & + & - & - & + & Rec & 7/1_10 \\
\hline 10 & $7 / 20$ & + & - & - & + & Rec & 7/20_10 \\
\hline 11 & $10 / 11$ & + & - & - & + & Rec & 10/11_10 \\
\hline 12 & $10 / 24$ & + & - & - & + & Rec & 10/24_10 \\
\hline 13 & $12 / 7$ & + & - & - & + & Rec & 12/7_10 \\
\hline 14 & $12 / 18$ & + & - & - & + & Rec & 12/18_10 \\
\hline 15 & $13 / 20$ & + & - & - & + & Rec & 13/20_10 \\
\hline 16 & $14 / 25$ & + & - & - & + & Rec & 14/25_10 \\
\hline 17 & $15 / 3$ & + & - & - & + & Rec & 15/3_10 \\
\hline 18 & $15 / 7$ & + & - & - & + & Rec & 15/7_10 \\
\hline 19 & $15 / 15$ & + & - & - & + & Rec & 15/15_10 \\
\hline 20 & $16 / 8$ & + & - & - & + & Rec & 16/8_10 \\
\hline 21 & $9 / 13$ & + & - & - & + & $\operatorname{Rec}$ & $9 / 13$ \\
\hline 22 & $9 / 14$ & - & + & - & + & $\mathrm{D}$ & $9 / 14$ \\
\hline 23 & $9 / 15$ & + & - & - & + & $\operatorname{Rec}$ & $9 / 15$ \\
\hline 24 & $9 / 16$ & - & + & - & + & $\mathrm{D}$ & $9 / 16$ \\
\hline 25 & $10 / 13$ & - & + & - & + & $\mathrm{D}$ & $10 / 13$ \\
\hline 26 & $10 / 14$ & + & - & - & + & $\operatorname{Rec}$ & $10 / 14$ \\
\hline 27 & $10 / 15$ & - & + & - & + & $\mathrm{D}$ & $10 / 15$ \\
\hline 28 & $10 / 16$ & + & - & - & + & Rec & $10 / 16$ \\
\hline
\end{tabular}




\section{Sekvencioniranje}

Svih 20 pozitivnih uzoraka je sekvencionirano u C-ter NIb-N-ter regionu genoma. Dobijene sekvence PPV-Rec i PPV-D izolata su međusobno uparene i date u prilozima 7 i 8 . U prilozima su navedene oznake sekvenci zaraženih stabala iz 2009. godine jer su sekvence izolata sa istih stabala iz 2010. godine identične.

\begin{tabular}{|c|c|c|c|c|c|c|c|c|}
\hline 29 & & & & 0 & $\bullet$ & 0 & o & \\
\hline 28 & & & & 0 & 0 & 0 & $\circ$ & \\
\hline 27 & & & & 0 & 0 & $\bullet$ & $\circ$ & \\
\hline 26 & & & & 0 & 0 & ० & o & \\
\hline 25 & & & & O & $\circ$ & 0 & o & \\
\hline 24 & & & ० & $\circ$ & $\circ$ & o & o & \\
\hline 23 & & & 0 & 0 & 0 & $\bullet$ & o & \\
\hline 22 & & & 0 & 0 & 0 & o & o & \\
\hline 21 & & & $\bullet$ & 0 & o & 0 & o & \\
\hline 20 & & & 0 & 0 & 0 & 0 & $\bullet$ & \\
\hline 19 & & & 0 & O & $\circ$ & 0 & o & \\
\hline 18 & & & 0 & 0 & 0 & 0 & o & \\
\hline 17 & & & 0 & 0 & 0 & $\bullet$ & o & \\
\hline 16 & & & 0 & 0 & $\circ$ & o & o & \\
\hline 15 & & & o & 0 & 0 & o & o & \\
\hline 14 & & & O & 0 & $\circ$ & o & o & \\
\hline 13 & & & 0 & 0 & 0 & 0 & o & \\
\hline 12 & & 0 & 0 & 0 & 0 & 0 & o & \\
\hline 11 & & 0 & 0 & 0 & 0 & o & o & \\
\hline 10 & & 0 & 0 & 0 & 0 & 0 & o & \\
\hline 9 & & 0 & 0 & 0 & 0 & 0 & o & \\
\hline 8 & & 0 & 0 & 0 & 0 & 0 & o & \\
\hline 7 & & $\circ$ & $\circ$ & 0 & o & 0 & o & \\
\hline 6 & & $\circ$ & $\circ$ & 0 & 0 & O & o & \\
\hline 5 & & 0 & 0 & 0 & 0 & 0 & o & \\
\hline 4 & & O & 0 & 0 & 0 & 0 & o & \\
\hline 3 & O & 0 & $\bullet$ & 0 & 0 & 0 & o & \\
\hline 2 & 0 & ० & 0 & 0 & $\bullet$ & 0 & o & \\
\hline 1 & $\circ$ & 0 & 0 & 0 & 0 & $\bullet$ & $\bullet$ & \\
\hline & 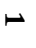 & $N$ & $\omega$ & $A$ & $\boldsymbol{G}$ & $a$ & & \\
\hline
\end{tabular}

Šema 4. Mapa eksperimentalnog zasada šljive sa pozicijama zaraženih stabala u 2010.

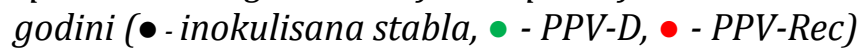




\section{TCS analiza}

Genealoška povezanost izolata koji su detektovani u eksperimentalnom zasadu tokom 2009 i 2010. godine, izolata sa inokulisanih stabala i izolata iz neposredne okoline izvršena je TCS analizom. Na slikama 35 i 36 date su mreže genealoške povezanosti sekvenci C-ter NIb-N-ter CP regiona PPV-D i PPV-Rec izolata. Analiza pokazuje da izolati sa novozaraženih stabala ne potiču sa inokulisanih stabala.

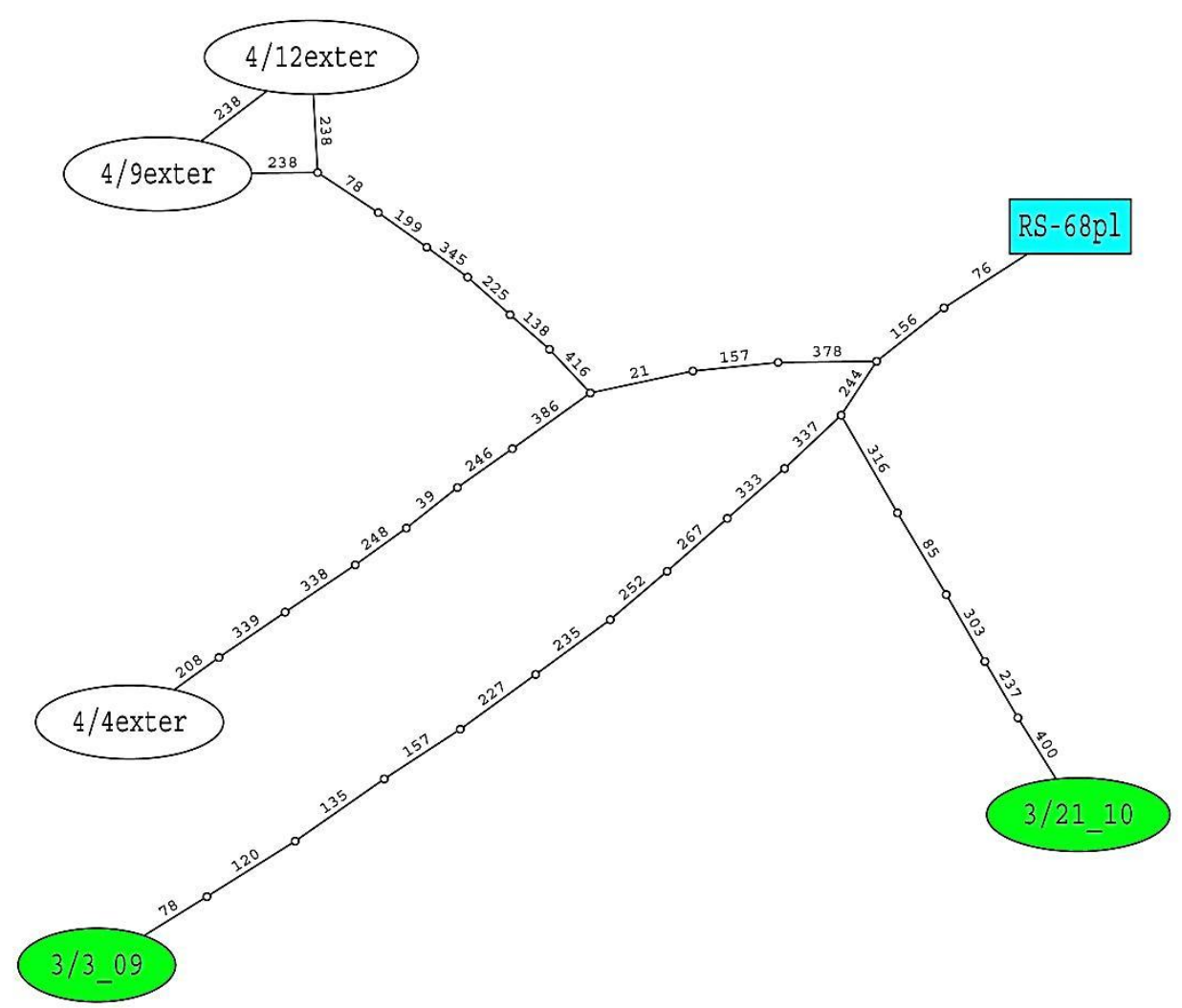

Slika 35. Mreža genealoške povezanosti analiziranih PPV-D izolata iz eksperimentalnog zasada (označeni zeleno), njegove okoline (označeni belo) i PPV-D izolata sa inokulisanih stabala (označen plavo). Svaka linija predstavlja pojedinačnu mutaciju između dva izolata sa pozicijom mutacije. Nedostajuće (hipotetičke) sekvence su predstavljene kružićima. 


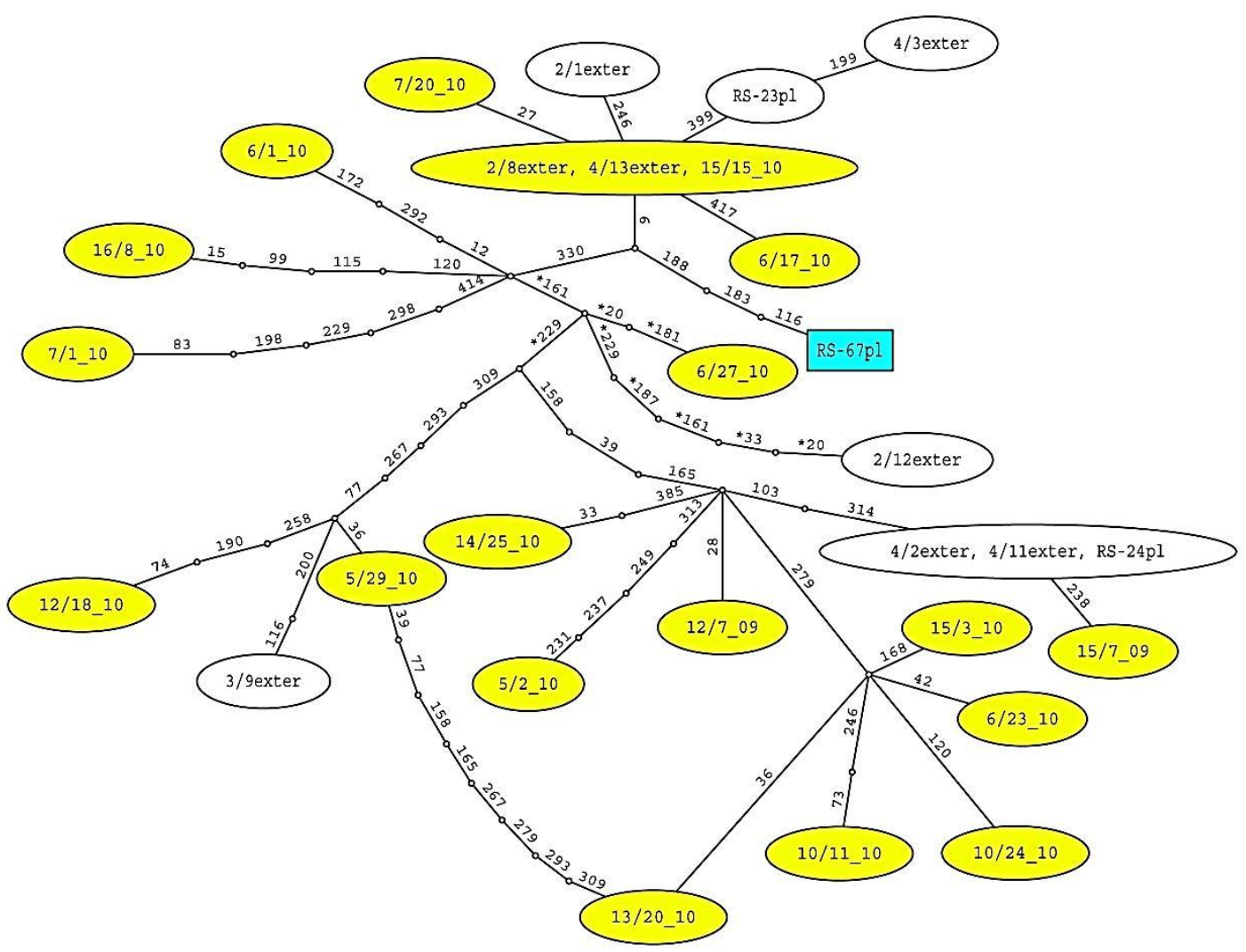

Slika 36. Mreža genealoške povezanosti analiziranih PPV-Rec izolata iz eksperimentalnog zasada (označeni žuto), njegove okoline (označeni belo) i PPV-Rec izolata sa inokulisanih stabala (označen plavo). Svaka linija predstavlja pojedinačnu mutaciju između dva izolata sa pozicijom mutacije. Nedostajuće (hipotetičke) sekvence su predstavljene kružićima.

\section{Praćenje brojnosti i vrsta biljnih vaši}

Tokom 2010. godine praćenje prisustva vrsta i brojnosti lisnih vaši vršeno je u periodu od 29. aprila do 21. septembra. Primenom Sticky-shoot metode je tokom ovog perioda uhvaćeno ukupno 1289 krilatih jedinki preko 30 vrsta lisnih vaši na tretiranim listovima (Prilog 9). Najveća brojnost populacije lisnih vaši $u$ prolećnom periodu bila je od 4-9. juna, dok jesenji pik nije bio izražen. Najveći broj uhvaćenih vrsta pripada rodovima Myzocallis $(82,6 \%)$ i Aphis $(7,4 \%)$. Brojnost vrsta koje su opisane kao vektori je bila veoma niska u odnosu na ostale uhvaćene vrste (Grafikon 8). 


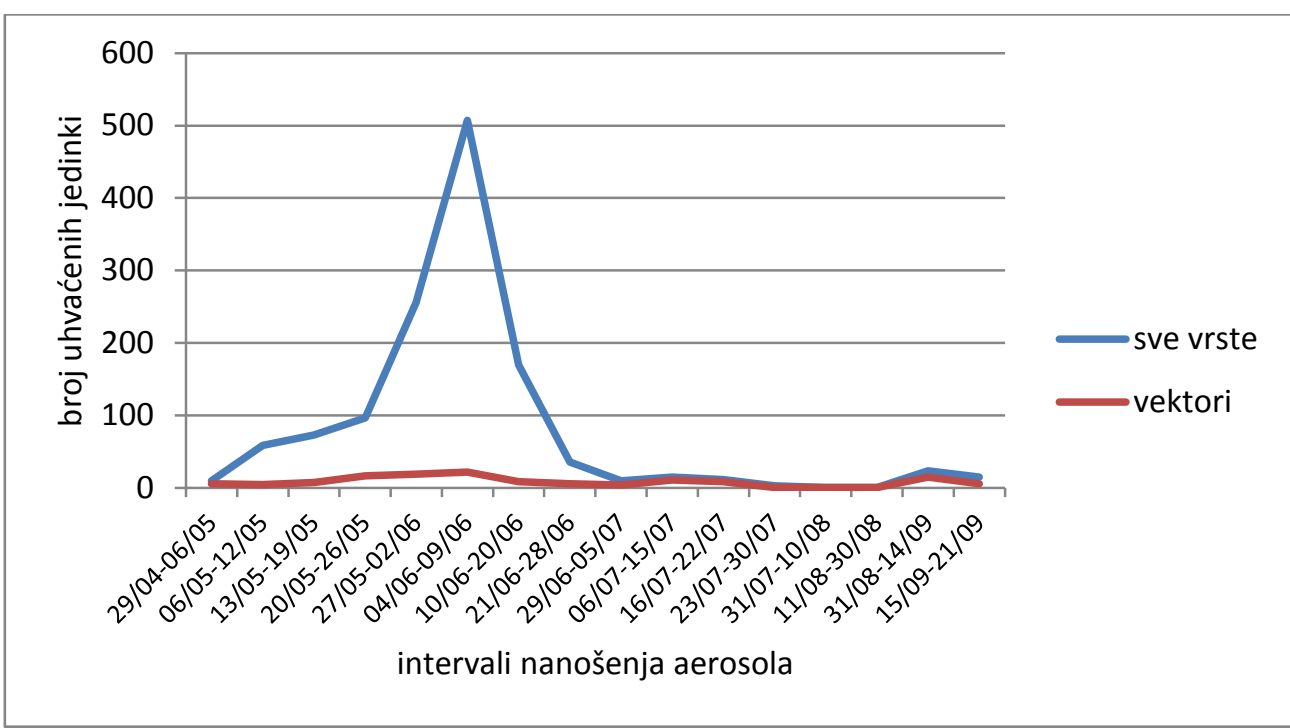

Grafikon 8. Dinamika populacija krilatih formi lisnih vaši uhvaćenih primenom Sticky-shoot metode tokom 2010. godine

\subsubsection{Ispitivanja prisutva virusa šarke u eksperimentalnom zasadu u četvrtoj godini istraživanja (2011. godina)}

\section{Vizuelni pregledi}

Tokom prve dekade juna 2011. godine sproveden je prvi vizuelni pregled stabala šljive u zasadu. Tokom pregleda su na 45 stabala (uključujući 8 inokulisanih) uočeni simptomi virusa šarke šljive. Ocena simptoma je data u tabeli 23.

$\mathrm{Na}$ znatnom broju stabala simptomi su bili lokalizovani. Na 8 stabala primećeno je tek po par listova sa veoma blagim do blagim simptomima. Kod 12 stabala simptomi su bili lokalizovani na nekoliko grančica jedne skeletne grane, dok je na 10 stabala bilo simptoma na više skeletnih grana. Svega 7 stabala je bilo sa simptomima sistemično izraženih po čitavoj kruni. Intenzitet simptoma na listovima se kretao od jako blagih do jako izraženih u vidu mozaika i prstenastih pega.

$\mathrm{Na}$ inokulisanim stablima su simptomi bili ujednačeno izraženi na gotovo celoj kruni u vidi mozaika i prstenastih pega, a po prvi put su primećeni simptomi 
tipa prosvetljavanja glavnog i bočnih lisnih nerava. Simptomi su bili izraženi do jako izraženi.

Tabela 23. Opisni rezultati vizuelnog pregleda stabala šljive u eksperimentalnom zasadu u

\begin{tabular}{|c|c|c|c|c|}
\hline Broj & Pozicija stabla & $\begin{array}{c}\text { Ocena } \\
\text { simptoma }\end{array}$ & Izgled simptoma & $\begin{array}{l}\text { Intenzitet } \\
\text { simptoma }\end{array}$ \\
\hline 1 & $3 / 3$ & 3 & Mo & 3 \\
\hline 2 & $3 / 19$ & 1 & Mo & 1 \\
\hline 3 & $3 / 21$ & 4 & PP, Mo & 4 \\
\hline 4 & $4 / 2$ & 1 & Mo, PP & 1 \\
\hline 5 & $4 / 10$ & 1 & Mo & 1 \\
\hline 6 & $5 / 2$ & 3 & Mo, PP, PN & 2 \\
\hline 7 & $5 / 5$ & 2 & Mo, PP & 2 \\
\hline 8 & $5 / 29$ & 4 & Mo, PP & 3 \\
\hline 9 & $6 / 1$ & 1 & PP & 1 \\
\hline 10 & $6 / 17$ & 4 & Mo, PP & 4 \\
\hline 11 & $6 / 23$ & 4 & Mo, PP & 3 \\
\hline 12 & $6 / 27$ & 4 & Mo & 3 \\
\hline 13 & $7 / 1$ & 2 & Mo, PP & 2 \\
\hline 14 & $7 / 3$ & 1 & Mo & 2 \\
\hline 15 & $7 / 8$ & 1 & Mo, PP & 2 \\
\hline 16 & $7 / 20$ & 4 & Mo, PP & 3 \\
\hline 17 & $8 / 4$ & 2 & Mo & 2 \\
\hline 18 & $8 / 8$ & 1 & Mo & 2 \\
\hline 19 & $9 / 29$ & 2 & Mo, PP & 2 \\
\hline 20 & $10 / 8$ & 2 & Mo & 2 \\
\hline 21 & $10 / 9$ & 2 & Mo, PP & 2 \\
\hline 22 & $10 / 11$ & 2 & Mo & 3 \\
\hline 23 & $10 / 22$ & 2 & Mo & 2 \\
\hline 24 & $10 / 24$ & 3 & Mo, PP, PN & 3 \\
\hline 25 & $10 / 28$ & 2 & Mo, PN & 2 \\
\hline 26 & $11 / 20$ & 3 & Mo, PP & 2 \\
\hline 27 & $12 / 7$ & 3 & Mo, PP & 2 \\
\hline 28 & $12 / 18$ & 1 & Mo & 1 \\
\hline 29 & $13 / 3$ & 2 & Mo & 3 \\
\hline 30 & $13 / 20$ & 3 & Mo, PP & 3 \\
\hline 31 & $13 / 25$ & 2 & PP, Mo & 2 \\
\hline 32 & $14 / 25$ & 3 & PP, Mo & 4 \\
\hline 33 & $15 / 1$ & 2 & Mo & 3 \\
\hline 34 & $15 / 3$ & 3 & Mo & 2 \\
\hline 35 & $15 / 7$ & 3 & Mo, PP & 3 \\
\hline 36 & $15 / 15$ & 4 & Mo & 3 \\
\hline 37 & $16 / 8$ & 3 & PP, Mo & 3 \\
\hline 38 & $9 / 13$ & 3 & Mo, PP & 3 \\
\hline 39 & $9 / 14$ & 3 & Mo & 3 \\
\hline 40 & $9 / 15$ & 3 & Mo, PP & 4 \\
\hline 41 & $9 / 16$ & 3 & Mo, PN & 3 \\
\hline 42 & $10 / 13$ & 3 & Mo, PP, PN & 3 \\
\hline 43 & $10 / 14$ & 3 & Mo, PP & 3 \\
\hline 44 & $10 / 15$ & 3 & Mo, PN & 3 \\
\hline 45 & $10 / 16$ & 3 & Mo, PP & 4 \\
\hline
\end{tabular}

Tokom jula i avgusta 2011. godine ponovljeni su vizuelni pregledi u kojima nisu utvrđena nova stabla sa simptomima šarke. Tokom ovih pregleda na nekim 
stablima je bilo teško uočiti simptome virusa šarke. Radi se o stablima 3/19, 4/2, $4 / 10,6 / 1,7 / 3,7 / 8,8 / 8$ i 12/18, gde je tokom prvog pregleda uočeno samo par listova sa simptomima.

Neposredno po pregledu stabala šljive u eksperimentalnom zasadu, pregledana su i sva stabla šljive iz obližnjeg malog zasada i uzeti su uzorci sa svih 38 stabala za IC-RT-PCR test.

\section{ELISA test}

U prvoj dekadi jula 2011. godine ELISA testom su sva stabla šljive $u$ eksperimentlnom zasadu ispitana na prisustvo virusa šarke šljive. Od svih analiziranih stabala, virus šarke je utvrđen kod svih stabala koja su pokazivala simptome virusa šarke (Tabela 23). U ostalim stablima bez simptoma nije detektovan virus šarke.

\section{IC-RT-PCR}

Svi pozitivni uzorci iz ELISA testa su dalje analizirani IC-RT-PCR testom (tabela 24). Analiza je pokazala da je u 5 stabala $(3 / 3,3 / 19,3 / 21,9 / 29$ i 13/3) prisutan PPV-D soj, a u 32 stabla (4/2, 4/10, 5/2, 5/5, 5/29, 6/1, 6/17, 6/23, 6/27, $7 / 1,7 / 3,7 / 8,7 / 20,8 / 4,8 / 8,10 / 8,10 / 9,10 / 11,10 / 22,10 / 24,10 / 28,11 / 20$, $12 / 7,12 / 18,13 / 20,13 / 25,14 / 25,15 / 1,15 / 3,15 / 7,15 / 15$ i 16/8) prisutan je PPV-Rec soj (Šema 5). Kod inokulisanih stabala rezultati su i tokom ove godine potvrdili održavanje pojedinačne infekcije odgovarajućim sojem. 
Tabela 24. Rezultati tipiziranja PPV izolata iz eksperimentalnog zasada

\begin{tabular}{|c|c|c|c|c|c|c|c|}
\hline \multirow[b]{3}{*}{ Broj } & \multicolumn{6}{|c|}{ REZULTATI PCR ANALIZA } & \multirow[b]{3}{*}{$\begin{array}{c}\text { Oznaka } \\
\text { sekvence }\end{array}$} \\
\hline & \multicolumn{3}{|c|}{ N-ter CP } & \multicolumn{2}{|c|}{ CI } & \multirow[b]{2}{*}{ Soj } & \\
\hline & Pozicija stabla & P4-P3M & P4-P3D & CIP-M & CIP-D & & \\
\hline 1 & $3 / 3$ & - & + & - & + & D & 3/3_11 \\
\hline 2 & $3 / 19$ & - & + & - & + & D & 3/19_11 \\
\hline 3 & $3 / 21$ & - & + & - & + & D & 3/21_11 \\
\hline 4 & $4 / 2$ & + & - & - & + & $\operatorname{Rec}$ & 4/2_11 \\
\hline 5 & $4 / 10$ & + & - & - & + & Rec & 4/10_11 \\
\hline 6 & $5 / 2$ & + & - & - & + & Rec & 5/2_11 \\
\hline 7 & $5 / 5$ & + & - & - & + & Rec & 5/5_11 \\
\hline 8 & $5 / 29$ & + & - & - & + & $\operatorname{Rec}$ & 5/29_11 \\
\hline 9 & $6 / 1$ & + & - & - & + & Rec & 6/1_11 \\
\hline 10 & $6 / 17$ & + & - & - & + & Rec & 6/17_11 \\
\hline 11 & $6 / 23$ & + & - & - & + & Rec & $6 / 23 \_11$ \\
\hline 12 & $6 / 27$ & + & - & - & + & Rec & $6 / 27 \_11$ \\
\hline 13 & $7 / 1$ & + & - & - & + & Rec & 7/1_11 \\
\hline 14 & $7 / 3$ & + & - & - & + & Rec & 7/3_11 \\
\hline 15 & $7 / 8$ & + & - & - & + & Rec & 7/8_11 \\
\hline 16 & $7 / 20$ & + & - & - & + & Rec & 7/20_11 \\
\hline 17 & $8 / 4$ & + & - & - & + & Rec & 8/4_11 \\
\hline 18 & $8 / 8$ & + & - & - & + & Rec & 8/8_11 \\
\hline 19 & $9 / 29$ & - & + & - & + & D & 9/29_11 \\
\hline 20 & $10 / 8$ & + & - & - & + & Rec & 10/8_11 \\
\hline 21 & $10 / 9$ & + & - & - & + & Rec & 10/9_11 \\
\hline 22 & $10 / 11$ & + & - & - & + & Rec & 10/11_11 \\
\hline 23 & $10 / 22$ & + & - & - & + & Rec & 10/22_11 \\
\hline 24 & $10 / 24$ & + & - & - & + & Rec & 10/24_11 \\
\hline 25 & $10 / 28$ & + & - & - & + & Rec & 10/28_11 \\
\hline 26 & $11 / 20$ & + & - & - & + & $\operatorname{Rec}$ & 11/20_11 \\
\hline 27 & $12 / 7$ & + & - & - & + & Rec & 12/7_11 \\
\hline 28 & $12 / 18$ & + & - & - & + & Rec & 12/18_11 \\
\hline 29 & $13 / 3$ & - & + & - & + & D & 13/3_11 \\
\hline 30 & $13 / 20$ & + & - & - & + & Rec & 13/20_11 \\
\hline 31 & $13 / 25$ & + & - & - & + & Rec & 13/25_11 \\
\hline 32 & $14 / 25$ & + & - & - & + & $\operatorname{Rec}$ & 14/25_11 \\
\hline 33 & 15/1 & + & - & - & + & Rec & 15/1_11 \\
\hline 34 & $15 / 3$ & + & - & - & + & Rec & 15/3_11 \\
\hline 35 & $15 / 7$ & + & - & - & + & Rec & 15/7_11 \\
\hline 36 & $15 / 15$ & + & - & - & + & Rec & 15/15_11 \\
\hline 37 & $16 / 8$ & + & - & - & + & Rec & 16/8_11 \\
\hline 38 & $9 / 13$ & + & - & - & + & $\operatorname{Rec}$ & $9 / 13$ \\
\hline 39 & $9 / 14$ & - & + & - & + & $\mathrm{D}$ & $9 / 14$ \\
\hline 40 & $9 / 15$ & + & - & - & + & $\operatorname{Rec}$ & $9 / 15$ \\
\hline 41 & $9 / 16$ & - & + & - & + & $\mathrm{D}$ & $9 / 16$ \\
\hline 42 & $10 / 13$ & - & + & - & + & $\mathrm{D}$ & $10 / 13$ \\
\hline 43 & $10 / 14$ & + & - & - & + & $\operatorname{Rec}$ & $10 / 14$ \\
\hline 44 & $10 / 15$ & - & + & - & + & $\mathrm{D}$ & $10 / 15$ \\
\hline 45 & $10 / 16$ & + & - & - & + & $\operatorname{Rec}$ & $10 / 16$ \\
\hline
\end{tabular}




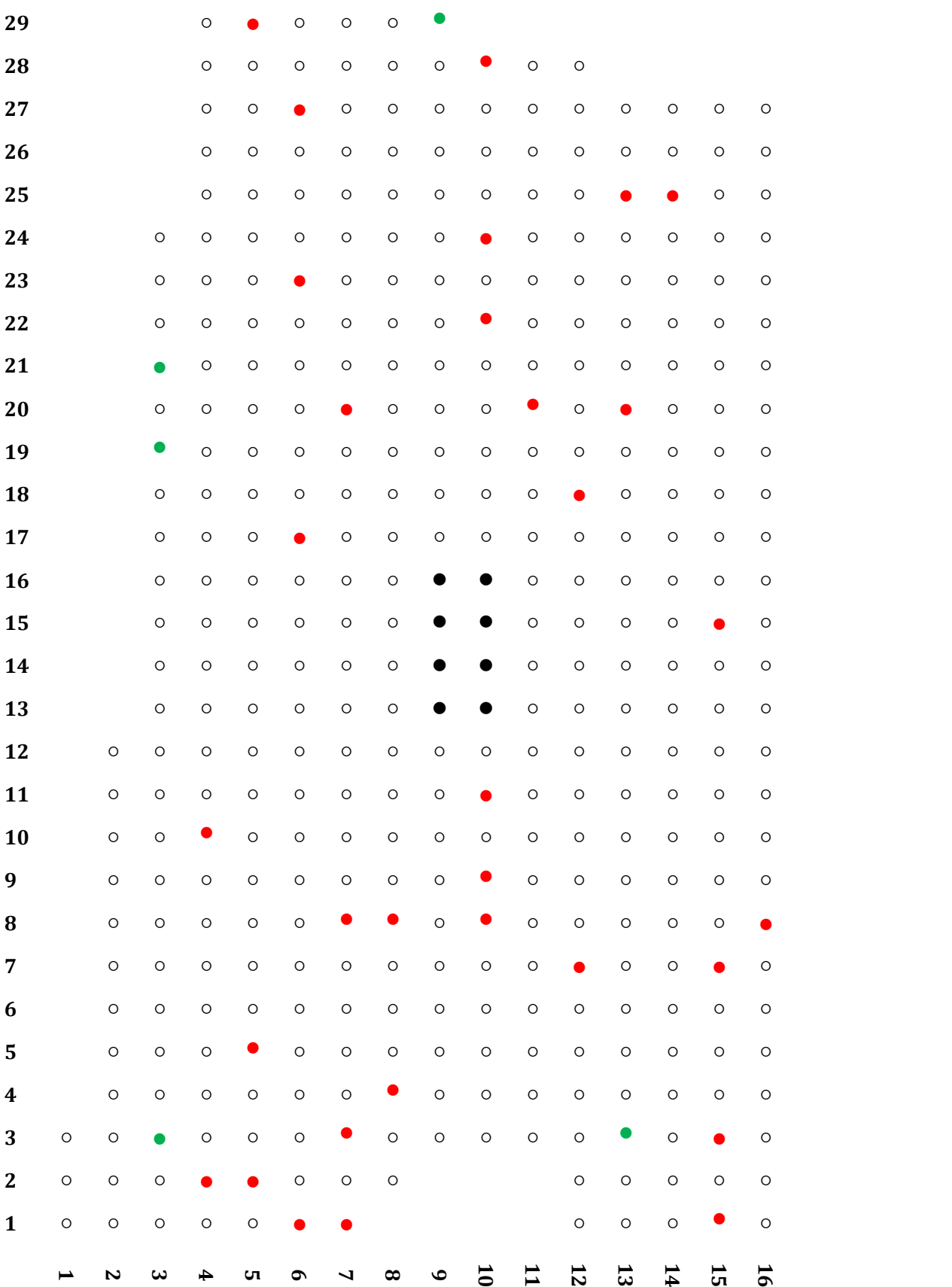

Šema 5. Mapa eksperimentalnog zasada šljive sa pozicijama zaraženih stabala u 2011.

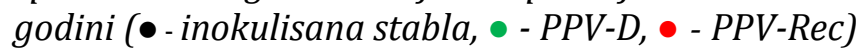

IC-RT-PCR analizom su tokom 2011. godine ispitana i sva stabla iz malog zasada šljive iz neposredne blizine eksperimentalnog zasada. Ispitano je svih 38 stabala iz zasada i rezultati su dati u tabeli 25. 
Tabela 25. Rezultati analize uzoraka iz malog zasada šljive

\begin{tabular}{|c|c|c|c|c|c|c|c|}
\hline \multicolumn{8}{|c|}{ REZULTATI PCR ANALIZA } \\
\hline \multirow[b]{2}{*}{ Broj } & \multirow[b]{2}{*}{$\begin{array}{c}\text { Pozicija } \\
\text { stabla }\end{array}$} & \multicolumn{2}{|c|}{ N-ter CP } & \multicolumn{2}{|c|}{ CI } & \multirow[b]{2}{*}{ Soj } & \multirow[b]{2}{*}{$\begin{array}{c}\text { Oznaka } \\
\text { sekvence }\end{array}$} \\
\hline & & P4-P3M & P4-P3D & CIP-M & CIP-D & & \\
\hline 1 & $4 / 13$ & + & - & - & + & $\operatorname{Rec}$ & 4/13exter \\
\hline 2 & $3 / 3$ & + & - & - & + & $\operatorname{Rec}$ & $3 / 3$ exter \\
\hline 3 & $3 / 1$ & - & - & - & - & $\mathrm{NEG}^{\mathrm{a}}$ & - \\
\hline 4 & $4 / 3$ & + & - & - & + & $\operatorname{Rec}$ & 4/3exter \\
\hline 5 & $3 / 2$ & - & + & - & + & D & 3/2exter \\
\hline 6 & $4 / 7$ & + & - & - & + & Rec & 4/7exter \\
\hline 7 & $3 / 6$ & - & - & - & - & NEG & - \\
\hline 8 & $2 / 8$ & + & - & - & + & Rec & 2/8exter \\
\hline 9 & $3 / 8$ & + & - & - & + & Rec & 3/8exter \\
\hline 10 & $3 / 4$ & + & - & - & + & Rec & $3 / 4$ exter \\
\hline 11 & $2 / 3$ & + & - & - & + & Rec & $2 / 3$ exter \\
\hline 12 & $2 / 2$ & - & - & - & - & NEG & - \\
\hline 13 & $3 / 12$ & - & - & - & - & NEG & - \\
\hline 14 & $2 / 10$ & - & - & - & - & NEG & - \\
\hline 15 & $2 / 1$ & + & - & - & + & $\operatorname{Rec}$ & 2/1exter \\
\hline 16 & $3 / 13$ & - & - & - & - & NEG & - \\
\hline 17 & $2 / 5$ & + & - & - & + & Rec & $2 / 5$ exter \\
\hline 18 & $4 / 6$ & - & - & - & - & NEG & - \\
\hline 19 & $3 / 11$ & - & - & - & - & NEG & - \\
\hline 20 & $4 / 5$ & - & - & - & - & NEG & - \\
\hline 21 & $3 / 5$ & - & - & - & - & NEG & - \\
\hline 22 & $3 / 9$ & + & - & - & + & Rec & $3 / 9$ exter \\
\hline 23 & $4 / 1$ & - & - & - & - & NEG & - \\
\hline 24 & $4 / 4$ & - & + & - & + & D & 4/4exter \\
\hline 25 & $2 / 4$ & + & - & - & + & Rec & $2 / 4$ exter \\
\hline 26 & $2 / 6$ & - & - & - & - & NEG & - \\
\hline 27 & $3 / 7$ & + & - & - & + & Rec & $3 / 7$ exter \\
\hline 28 & $4 / 12$ & - & + & - & + & D & 4/12 exter \\
\hline 29 & $2 / 11$ & - & - & - & - & NEG & - \\
\hline 30 & $3 / 10$ & - & - & - & - & NEG & - \\
\hline 31 & $4 / 9$ & - & + & - & + & D & 4/9exter \\
\hline 32 & $2 / 13$ & + & - & - & + & Rec & 2/13exter \\
\hline 33 & $2 / 9$ & - & - & - & - & NEG & - \\
\hline 34 & $2 / 12$ & + & - & - & + & $\operatorname{Rec}$ & 2/12exter \\
\hline 35 & $4 / 11$ & + & - & - & + & Rec & 4/11exter \\
\hline 36 & $1 / 1$ & - & - & - & - & NEG & - \\
\hline 37 & $4 / 2$ & + & - & - & + & Rec & $4 / 2$ exter \\
\hline 38 & $2 / 7$ & - & - & - & - & NEG & - \\
\hline
\end{tabular}

a - negativan rezultat

Od 38 stabala šljive u malom zasadu, kod 21 stabla je utvrđen PPV. Kod 17 stabala je utvrđen PPV-Rec soj, kod 4 stabla PPV-D soj.

\section{Sekvencioniranje}

Izolati sa novozaraženih stabala iz eksperimentalnog zasada su sekvencionirani u C-ter NIb-N-ter regionu genoma. Sekvence su date u prilozima 10 i 11. 
Iz malog zasada šljive sekvencioniran je $\mathrm{C}$-ter $\mathrm{NIb}-\mathrm{N}$-ter region genoma 10 novozaraženih stabala: $2 / 3,2 / 4,2 / 5,2 / 13,3 / 2,3 / 3,3 / 4,3 / 7,3 / 8$ i 4/7. Sekvence ovih izolata su date u prilogu 12 .

\section{TCS analiza}

Genealoška povezanost izolata koji su detektovani u eksperimentalnom zasadu u periodu 2009-2011. godine, izolata sa inokulisanih stabala i izolata iz neposredne okoline izvršena je TCS analizom. Na slikama 37 i 38 date su mreže genealoške povezanosti sekvenci $\mathrm{C}$-ter $\mathrm{NIb}-\mathrm{N}$-ter $\mathrm{CP}$ regiona PPV-D i PPV-Rec izolata.

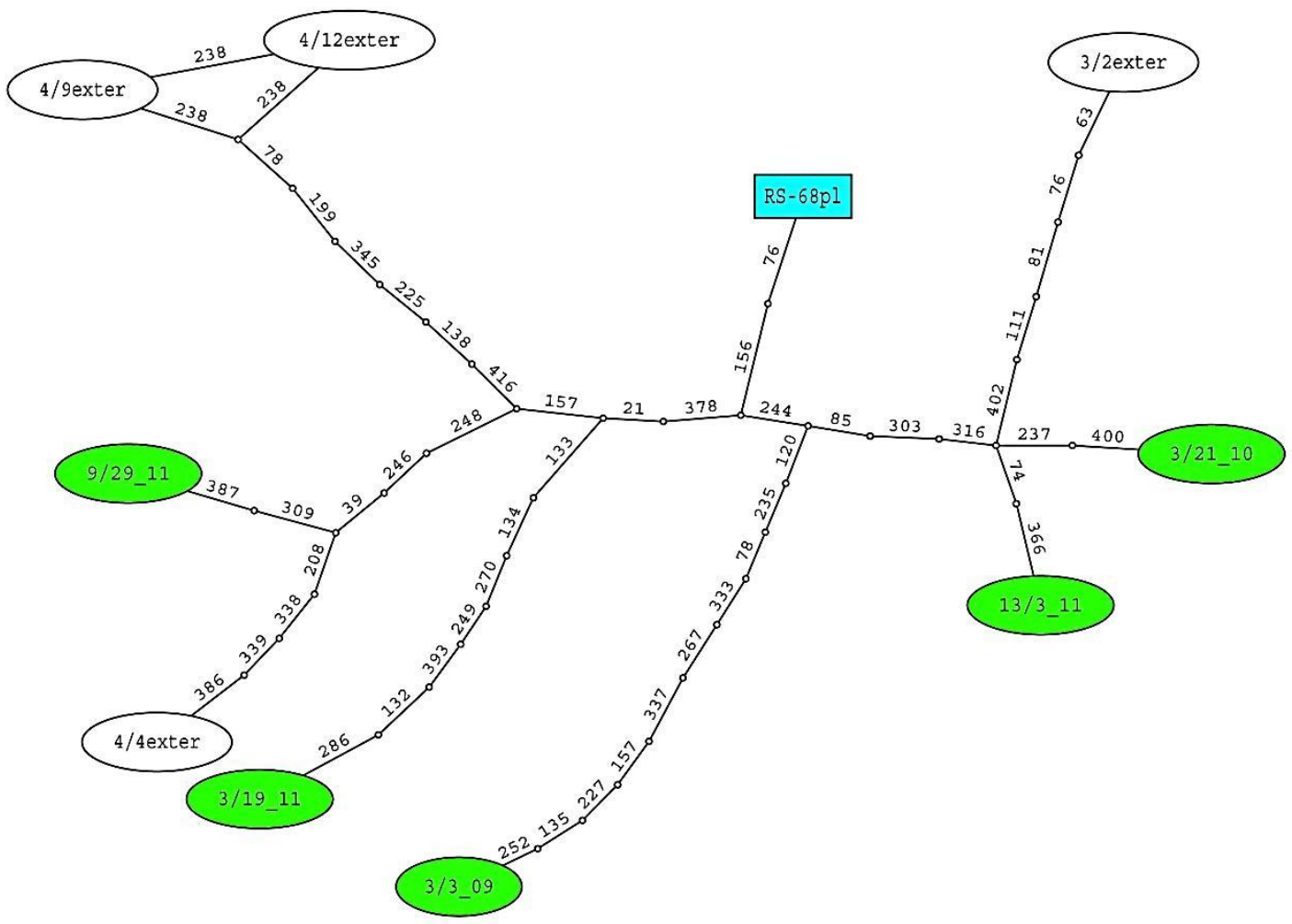

Slika 37. Mreža genealoške povezanosti analiziranih PPV-D izolata iz eksperimentalnog zasada (označeni zeleno), njegove okoline (označeni belo) i PPV-D izolata sa inokulisanih stabala (označen plavo). Svaka linija predstavlja pojedinačnu mutaciju između dva izolata sa pozicijom mutacije. Nedostajuće (hipotetičke) sekvence su predstavljene kružićima.

TCS analiza PPV-D izolata pokazuje da postoji velika divergentnost posmatranih izolata. Nijedan od izolata sa novozaraženih stabala $u$ 
eksperimentalnom zasadu ne potiče sa inokulisanih stabala, a ovi izolati takođe pokazuju veliku različitost nukleotidnih sekvenci u odnosu na izolate iz obližnjeg malog zasada.

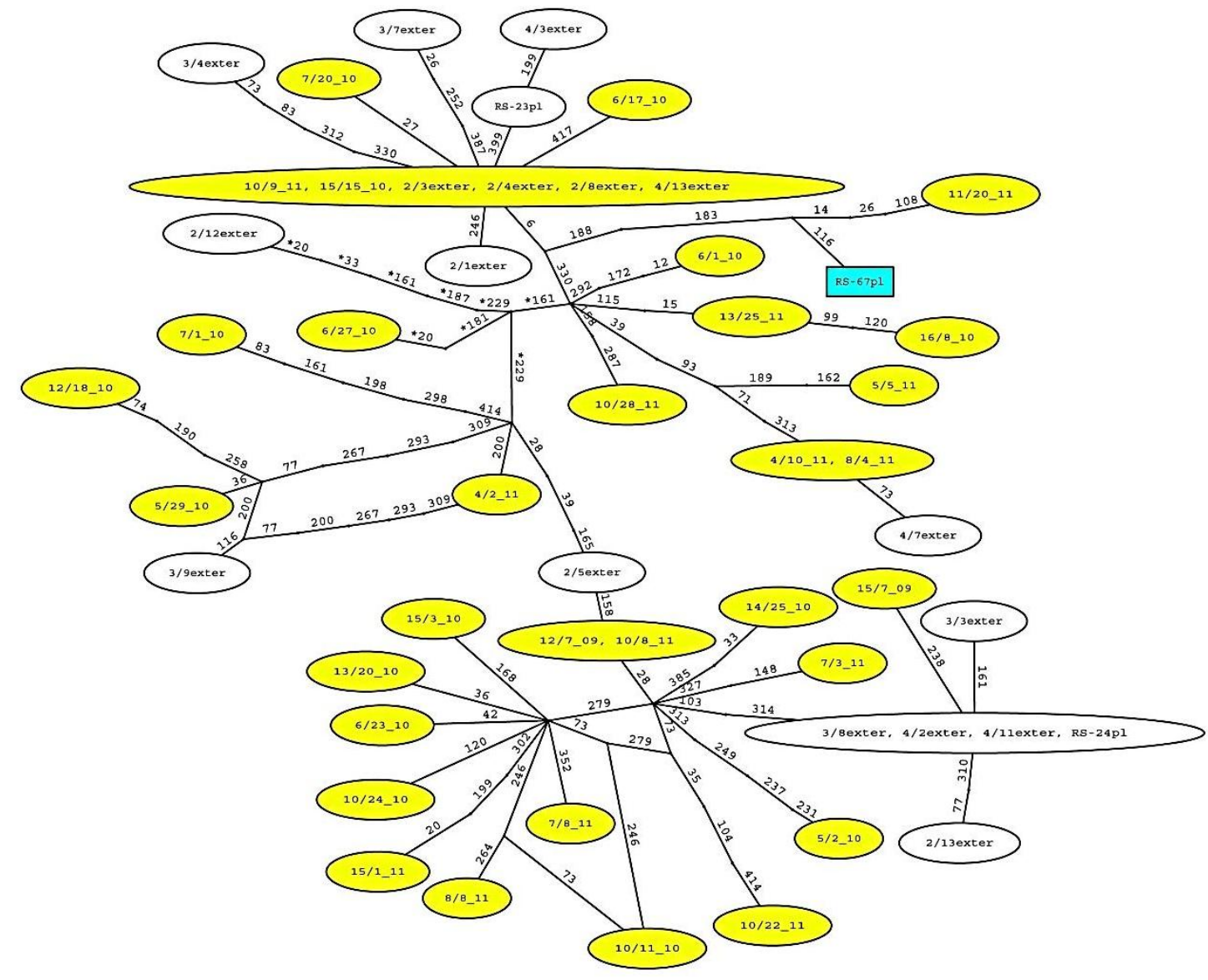

Slika 38. Mreža genealoške povezanosti analiziranih PPV-Rec izolata iz eksperimentalnog zasada (označeni žuto), njegove okoline (označeni belo) i PPV-Rec izolata sa inokulisanih stabala (označen plavo). Svaka linija predstavlja pojedinačnu mutaciju između dva izolata sa pozicijom mutacije. Nedostajuće (hipotetičke) sekvence su predstavljene kružićima.

TCS analiza PPV-Rec izolata je pokazala da samo jedan izolat (11/20_11) potiče sa inokulisanih stabala u eksperimentalnom zasadu. Sekvence većine izolata iz zasada su identične ili veoma slične sa sekvencama pojedinih izolata iz obližnjeg malog zasada.

\section{Praćenje brojnosti i vrsta biljnih vaši}

Tokom 2011. godine praćenje prisustva vrsta i brojnosti lisnih vaši vršeno je u periodu od 28. aprila do 23. septembra. Tokom ovog perioda uhvaćeno je samo 
290 krilatih jedinki preko 40 vrsta lisnih vaši na tretiranim listovima (Prilog 13).

Tokom 2011. godine brojnost lisnih vaši je bila na niskom nivou, tako da pikovi brojnosti nisu bili izraziti kao tokom 2009. i 2010. godine. Najveći broj uhvaćenih vrsta pripada rodovima: Aphis (49\%), Therioaphis (6\%), Pemphigus (9\%), Brachicaudus (4,5\%) i Rhopalosiphum (4\%). Najveća brojnost vrsta lisnih vaši koje su opisane kao vektori prati trend brojnosti ostalih vrsta, osim u intervalu kraj juna-početak jula (Grafikon 9).

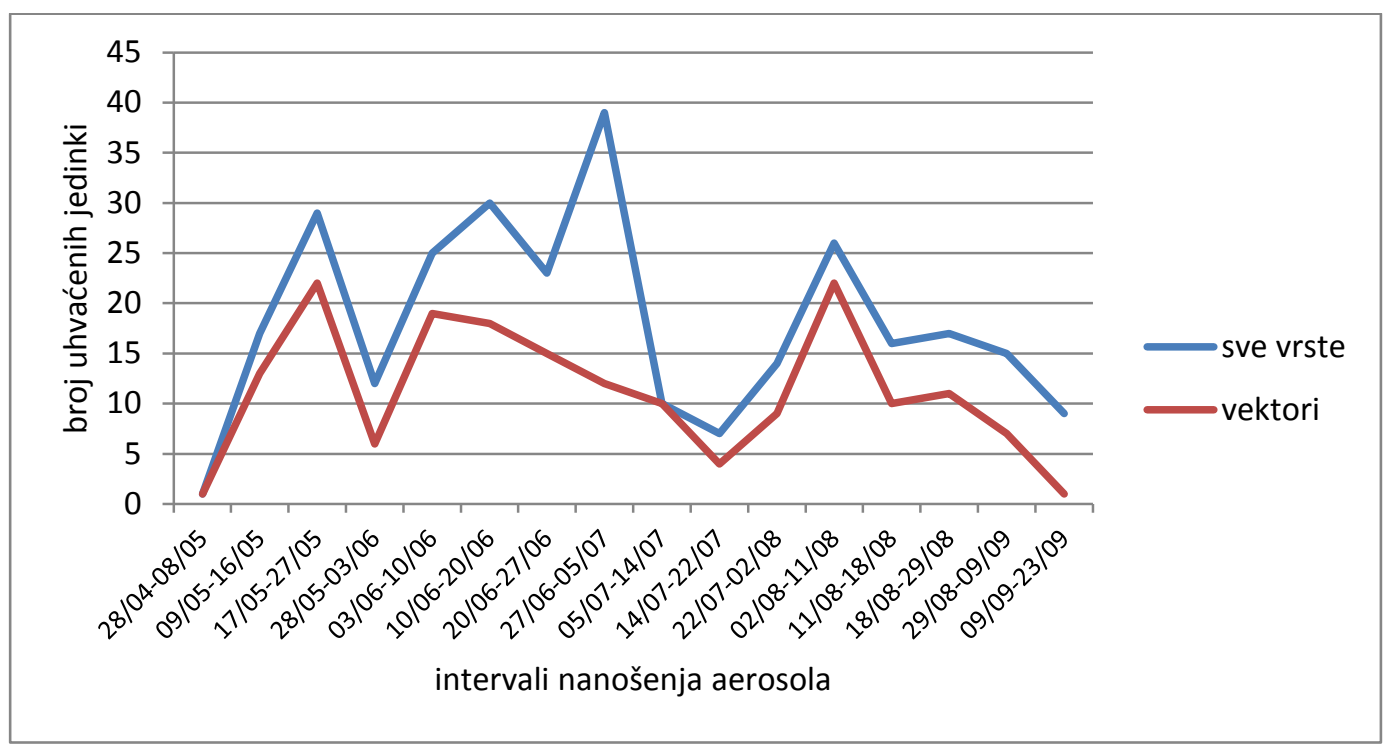

Grafikon 9. Dinamika populacija krilatih formi lisnih vaši uhvaćenih primenom Sticky-shoot metode tokom 2011. godine 


\section{DISKUSIJA}

\subsection{Rasprostranjenost sojeva šarke šljive u Srbiji}

\subsubsection{Rasprostranjenost sojeva šarke u zasadima šljive $i$ kajsije u Srbiji}

Tokom izrade ove disertacije sprovedeno je najobimnije ispitivanje raširenosti sojeva virusa šarke u zasadima šljive i kajsije kod nas. Rezultati istraživanja pokazuju da je u gotovo svim (278 od 283) analiziranim uzorcima potvrđeno prisustvo PPV. Vizuelnim pregledima su ciljana stabla sa jasnim simptomima prisustva šarke, što je i potvrđeno laboratorijskim analizama. Kod 5 uzoraka šljive sa veoma jasnim i karakterističnim simptomima, nalik onima koje izaziva virus šarke, IC-RT-PCR metodom nije utvrđeno prisustvo ovog virusa. Ovi uzorci su ELISA metodom analizirani i na prisustvo virusa hlorotične lisne pegavosti jabuke (Apple chlorotic leaf spot virus -ACLSV) i virusa prstenaste pegavosti paradajza (Tomato ring spot virus -ToRSV). Navedeni virusi mogu izazvati simptome nalik šarki, ali ELISA testom nije potvrđeno prisustvo niti ACLSV ni ToRSV.

U analiziranim uzorcima dominantno je utvrđen rekombinantni soj virusa šarke (55,7\%). U ranije sprovedenom istraživanju raširenosti sojeva virusa šarke šljive u Srbiji, sa nešto drugačijom strategijom uzimanja uzoraka, rekombinantni soj je utvrđen u 20,5\% analiziranih uzoraka (Jevremović, 2008). Tada je analiziran i znatan broj uzoraka breskve i nektarine (oko polovina analiziranih uzoraka), ali ukoliko se posmatraju samo uzorci šljive i kajsije, PPV-Rec soj je utvrđen u 36,4\% uzoraka. U strukturi gajenja koštičavih voćaka (računajući šljivu, kajsiju i breskvu) 
u Srbiji, šljiva ima dominantno mesto sa skoro 41 milion rodnih stabala, što je udeo od oko 89\% (Republički zavod za statistiku RS). Breskva i kajsija su zastupljene sa po 3,8 i 1,5 miliona rodnih stabala. Uzimajući u obzir ovu proporciju zastupljenosti Prunus vrsta domaćina PPV u Srbiji, može se zaključiti da je generalno kod nas dominantno prisutan PPV-Rec soj.

Nakon samo nekoliko godina od potvrde prisustva rekombinantnih izolata $\mathrm{u}$ Srbiji (Glasa et al., 2005) i prve studije prisustva i raširenosti ovog soja (Jevremović, 2008), rezultati pokazuju da je ovaj soj značajno prisutan u zasadima šljive i kajsije. PPV-Rec soj je ustanovljen tek 2004. godine zahvaljujući razvoju molekularnih metoda karakterizacije. Istraživanja koja su u Srbiji ranije sprovođena serološkim metodama su ukazivala samo na prisustvo PPV-M i PPV-D izolata (Dulić, 2003; Paunović i Jevremović, 2003). Visok procenat zastupljenosti rekombinantnog soja potvrđuje ranije pretpostavke o njegovom dugogodišnjem prisustvu na teritoriji Srbije (Jevremović, 2008). Glasa et al., (2005) su na bazi analize nekoliko PPV-Rec izolata iz Srbije izneli hipotezu da ovaj soj potiče sa teritorije bivše Jugoslavije. Široka rasprostranjenost rekombinantnih izolata je rezultat njihovog uspešnog prilagođavanja uslovima u prirodi i vrlo efikasnog mehanizma širenja.

Sa $26,3 \%$ prisustva, PPV-D soj zauzima drugo mesto po zastupljenosti u zasadima šljive i kajsije u Srbiji. U ranije sprovedenom istraživanju, Jevremović (2008) navodi približan procenat zastupljenosti PPV-D soja u uzorcima šljive i kajsije $-23,8 \%$.

PPV-M soj je tokom sprovedenih ispitivanja utvrđen u svega 5,4\% uzoraka, što ga stavlja na poslednje mesto po zastupljenosti kod šljive i kajsije u Srbiji. PPVM soj se u literaturi označava kao soj koji se u zasadima brzo širi, pre svega kod breskve (Quiot et al., 1995; Dallot et al., 1998, 2004). Rezultati ove disertacije pokazuju da je kod kajsije i šljive u Srbiji, PPV-M soj potpuno potisnut od strane druga dva utvrđena soja. 


\subsubsection{Sojevi virusa šarke u zasadima šljive}

Rezultati ispitivanja pokazuju da su sva tri soja virusa šarke prisutna $\mathrm{u}$ uzorcima šljive. Dominantno je zastupljen PPV-Rec soj (53,5\%), što potvrđuje rezultate ranijih istraživanja (Jevremović, 2008). Visok procenat zastupljenosti rekombinantnog soja potvrđuje pretpostavke o njegovom dugom prisustvu u zasadima šljive u Srbiji. Pored Srbije, PPV-Rec izolati na šljivi su potvrđeni u još 14 zemalja, ali za svega nekoliko zemalja postoje podaci o njegovoj raširenosti. U Bosni i Hercegovini je PPV-Rec utvrđen u 29\% ispitivanih uzoraka šljive (Matić et al., 2006). Nedavnim istraživanjima, Jevremović et al., (2010) su u $87 \%$ analiziranih uzoraka šljive iz BiH potvrdili prisustvo rekombinantnog soja. U Bugarskoj, PPVRec soj je zastupljen 18\%, a u Slovačkoj 49\% (Dallot et al., 2008). Zagrai et al., (2010) navode da je PPV-Rec soj u Rumuniji prisutan u niskom procentu (14\%). Visok procenat zastupljenosti PPV-Rec soja kod šljive je utvrđen i u Crnoj Gori (Viršček-Marn et al., 2012). Tokom istraživanja raširenosti sojeva šarke u Češkoj, Polak i Kominek (2009) nisu potvrdili prisustvo PPV-Rec soja u uzorcima šljive (P. domestica), već samo u 3\% uzoraka dženarike.

Drugi soj po zastupljenosti u zasadima šljive u Srbiji je PPV-D soj $(27,9 \%)$. Ovaj soj je prevalentan u zemljama zapadne i centralne Evrope. Dominantno je prisutan u zasadima u Austriji (89\%), Češkoj (95\%), Nemačkoj, Poljskoj i Rumuniji (73\%) (Polak i Kominek, 2009; Malinowski, 2006; Jaraush, 2006, Zagrai et al., 2010). U literaturi se navodi da je PPV-D soj neepidemični soj, ali obimna istraživanja koja su sprovedena u Češkoj ukazuju da i ovaj soj može izazvati epidemije kod šljive i dženarike (Polak, 2002; Polak i Kominek, 2009).

PPV-M soj je utvrđen u svega 5,4\% uzoraka šljive. U odnosu na ranije saopštene podatke o 23,5\% zastupljenosti kod šljive (Jevremović, 2008), ovo je oko 4 puta manja zastupljenost PPV-M soja. Sa povećanjem broja analiziranih uzoraka šljive došlo je do smanjenja udela PPV-M soja, dok je povećan udeo PPV-Rec soja. PPV-M soj se u Srbiji uglavnom vezuje za breskvu gde je dominantno prisutan sa 99\% (Jevremović, 2008). 
Kod šljive su utvrđene i mešane infekcije kod 13,2\% uzoraka. Dominantan je broj uzoraka gde su u mešanoj infekciji utvrđeni PPV-D i PPV-Rec soj. Po prvi put je potvrđena infekcija stabla šljive sa sva tri ispitivana soja PPV (PPV-M, PPV-D i PPV-Rec). Ovakva trostruka prirodna infekcija sojevima PPV u prirodi do sada nije opisana u literaturi. Mešane infekcije predstavljaju preduslov za pojavu novih rekombinanata i šljiva predstavlja „idealnog“ domaćina za ispoljavanje ovog fenomena.

Dobijeni rezultati pokazuju da su PPV-Rec i PPV-D soj u Srbiji veoma dobro adaptirani na ovu Prunus vrstu i da su gotovo potpuno potisnuli PPV-M soj iz zasada šljive. Visok procenat zaraze šljive ovim sojevima ukazuje na njihovo dugotrajno prisustvo u zasadima, kao i postojanje kompeticije između ova dva soja, gde prezentovani rezultati pokazuju „superiornost“ PPV-Rec soja.

\subsubsection{Sojevi virusa šarke u zasadima kajsije}

Broj analiziranih uzoraka kajsije je relativno mali (20 uzoraka), ali odnos uzoraka šljiva/kajsija odgovara njihovoj zastupljenosti u zasadima u Srbiji. U analiziranim uzorcima dominantno je utvrđen PPV-Rec soj (85\%), dok su ostala dva soja (PPV-M i PPV-D) utvrđeni u svega po 5\% uzoraka. Simptomi šarke na listovima kajsije su slabije izraženi i uglavnom lokalizovani na unutrašnje delove krune. Prilikom obilaska zasada kajsije i uzimanja uzoraka utvrđena su dva različita slučaja. Prvi, gde je u zasadima bilo veoma lako uočiti simptome na listovima i gde je procenat zaraze u zasadima visok. U drugom slučaju, u zasadima je bilo veoma teško locirati zaražena stabla jer su simptomi veoma blagi ili simptoma nije bilo.

U literaturi se navodi da rekombinantni soj pre svega zaražava šljivu, dok je kod kajsije ređa pojava (Kollerova et al., 2008). Rezultati dosadašnjih istraživanja sojeva PPV u Institutu za voćarstvo - Čačak su pokazali da je PPV-Rec soj u visokom procentu prisutan kod kajsije u Srbiji. Takođe, Jevremović et al., (2010) su PPV-Rec soj detektovali u većini ispitivanih uzoraka kajsije iz Bosne i Hercegovine. Osim Srbije i Bosne i Hercegovine, PPV-Rec je na kajsiji utvrđen i u Bugarskoj, 
Češkoj, Italiji, Mađarskoj, Slovačkoj i Pakistanu, ali bez preciznijih podataka o njegovoj raširenosti u okviru ove Prunus vrste (Glasa et al., 2004; Kollerova et al., 2006; Szathmáry i Palkovics, 2010).

\subsubsection{Zastupljenost sojeva na nivou zasada}

Analiza rezultata rasprostranjenosti sojeva šarke na nivou zasada pokazuje veliku heterogenost ispitivanih zasada $\mathrm{u}$ pogledu prisustva sojeva PPV. Procentualno su najzastupljeniji zasadi u kojima je utvrđen samo PPV-Rec soj (34\%) i zasadi u kojima su utvrđena dva soja: PPV-D i PPV-Rec soj (36\%). Sa druge strane, u svega $1 \%$ zasada utvrđeno je prisustvo samo PPV-M soja.

U više od polovine analiziranih zasada (53\%) utvrđeno je prisustvo dva ili sva tri soja. Prisustvo više sojeva u zasadu predstavlja preduslov za pojavu mešanih infekcija koje potencijalno mogu dovesti do stvaranja de novo rekombinantnih izolata.

\subsubsection{Geografska distribucija sojeva šarke}

Rezultati ispitivanja uzoraka iz 12 okruga Srbije pokazuju da ne postoji striktna geografska lokalizacija pojedinačnih sojeva šarke na teritoriji Srbije. Rekombinantni soj je utvrđen u svim ispitivanim okruzima, bilo u pojedinačnoj ili mešanim infekcijama, a dominantno je raširen u 8 okruga. PPV-D soj je takođe utvrđen u svim okruzima, a prevalentan je u 4 okruga (Nišavski, Pirotski, Rasinski i Zaječarski). Za razliku od PPV-Rec i PPV-D soja, PPV-M soj nije utvrđen u svim okruzima. Ovaj soj nije utvrđen u uzorcima iz Jablaničkog, Kosovsko-Mitrovačkog, Pirotskog i Rasinskog okruga. Ovaj rezultat ne znači da PPV-M soj nije prisutan u ovim okruzima, već da nije raširen u zasadima šljive i kajsije. Jevremović (2008) navodi da je PPV-M soj prisutan u analiziranim uzorcima breskve iz nekoliko lokaliteta u ovim okruzima.

Uzrok ovakve distribucije sojeva šarke na teritoriji Srbije je promet zaraženog sadnog materijala, koji do pre nekoliko godina nije strogo kontrolisan po važećim zakonima i pravilnicima. Sadni materijal zaražen lokalnim izolatima je unošen u nove lokalitete, gde je nastavljeno širenje izolata putem lisnih vaši. Karakterističan primer za ovaj način disperzije izolata je situacija u Zaječarskom 
okrugu, gde su u zasadima starosti 10-27 godina utvrđeni samo PPV-D i PPV-M soj (Prilog 1). U izolovanom zasadu šljive, starosti 2 godine, potvrđene su mešane infekcije tipa PPV-D+PPV-Rec koje nesumnjivo potiču od zaraženog sadnog materijala. Kao rezultat, u skorijoj budućnosti treba očekivati PPV-Rec soj u izvesnom procentu i u ovom lokalitetu.

\subsubsection{Analiza nukleotidnih sekvenci C-ter NIb-N-ter CP regiona}

Tokom izrade ovog rada određene su nukleotidne sekvence 41 odabranog izolata PPV. Osim PPV-Rec (23 izolata) i PPV-D (15 izolata), radi upoređivanja su odabrana i 3 PPV-M izolata. CP region genoma Potyvirus-a (naročito N-terminalni deo), pored P1 regiona, predstavlja najvarijabilniji region genoma i iz tog razloga se sekvence ovog regiona genoma često koriste za filogenetske analize (AlemanVerdaguer et al., 1997; Glasa et al., 2007). Osim toga, u C-terminalnom delu NIb regiona se nalazi tačka rekombinacije koja je karakteristična za PPV-Rec izolate (Glasa et al., 2004).

Rekonstruisano filogenetsko stablo od 467 bp fragmenta iz C-ter NIb-N-ter $\mathrm{CP}$ regiona genoma jasno pokazuje tri klastera izolata koji odgovaraju ispitivanim PPV sojevima. Rezultati filogenetske analize potvrđuju rezultate IC-RT-PCR tipiziranja i daju nova saznanja o izolatima/sojevima. $\mathrm{Na}$ rekonstruisanim filogenetskim stablima (Slike 22 i 23) nema atipičnog grupisanja pojedinačnih izolata unutar klastera, što pokazuje da su svi izolati tipični predstavnici odgovarajućih sojeva.

Procenjena vrednost genetičkog diverziteta $\mathrm{u}$ okviru PPV-Rec izolata ispitivanih u ovom radu je niska $0,017 \pm 0,003$ i viša od vrednosti za PPV-M izolate $0,012 \pm 0,004$. Vrednost genetičkog diverziteta za PPV-M izolate je urađena za samo tri analizirana izolata, pa ovu vrednost treba uslovno i razmatrati. Za razliku od PPV-M i PPV-Rec izolata, proračunata vrednost genetičkog diverziteta za PPV-D izolate je viša i iznosi 0,026 $\pm 0,004$ (Tabela 10). 
Rezultat TCS analize PPV-D sekvenci, kojom se procenjuje njihova genealoška povezanost, jasno pokazuje jednu mrežu sekvenci (Slika 24). Zadati limit parsimonije je 94\%, gde se sekvence razlikuju u najviše 8 mutacija. Ukoliko se limit parsimonije poveća na 95\%, takođe se dobija jedna mreža sekvenci (19 sekvenci), dok su van mreže sekvence izolata RS-46pl i RS-55pl (Slika nije prikazana). Pri ovom limitu parsimonije maksimalan broj mutacionih promena je 7, dok su najbliže konekcije sekvencama izolata 46pl i RS-55pl na 8 mutacija. TCS analiza pokazuje da ne postoji povezanost srodnih sekvenci sa geografskim poreklom izolata niti sa vrstom domaćina. Ovo se može objasniti distribucijom zaraženog sadnog materijala u geografski udaljene regione i okruge.

TCS analiza 46 sekvenci PPV-Rec izolata takođe pokazuje jednu mrežu sekvenci (Slika 25). Pri zadatom limitu parsimonije 95\%, limit konekcije izolata je 7 mutacija. Ne prikazanoj mreži koja povezuje PPV-Rec izolate zapaža se da se većina sekvenci koje se razlikuju u samo jednom nukleotidu nalaze na velikoj geografskoj udaljenosti. Tipični primeri su izolati: RS-10pl (Valjevo) i RS-47pl (Štrpce); RS-47pl (Štrpce) i RS-56pl (Šabac); RS-10pl (Valjevo) i RS-63pl (Vučje); RS-09pl (Topola) i RS-52pl (Jarinje). Povezanost sekvenci izolata koji su geografski blisko locirani uočava se kod izolata RS-32pl, RS-33ap i RS-25ap. Izolati RS-32pl i RS-33ap uzeti su sa stabala udaljenosti od 96m koja se nalaze u dva susedna voćnjaka, a oba izolata su udaljena oko 4,6 km od izolata RS-25ap. Sa povećanjem limita parsimonije na 96\% i 97\%, takođe se dobija jedna mreža sekvenci, ali u ovom slučaju izolat D76 nije povezan u rekonstruisanoj mreži (slike nisu prikazane). Najbliža konekcija sekvenci izolata D76 je na 7 mutacija (D115), dok je maksimalan broj mutacija 6 (96\%) i 5 mutacija (97\%). U poređenju sa TCS analizom sekvenci PPV-D izolata, za PPV-Rec izolate se zapaža manja divergentnost izolata. Kao i za PPV-D izolate, TCS analiza pokazuje da generalno ne postoji povezanost srodnih sekvenci sa geografskim poreklom izolata niti sa vrstom domaćina. Uzrok ovakvih rezultata filogeografske analize se takođe može objasniti nekontrolisanim širenjem izolata putem zaraženog sadnog materijala.

Filogenetska analiza 90 PPV izolata iz Srbije (46 PPV-Rec, 21 PPV-D i 23 PPV-M izolata) daje slične rezultate kao i analiza 41 izolata opisanih u ovoj 
disertaciji. Najveću vrednost genetičkog diverziteta pokazuje klaster PPV-D izolata 0,028 $\pm 0,004$, slede klaster PPV-M izolata 0,020 $\pm 0,003$ i klaster rekombinantnih

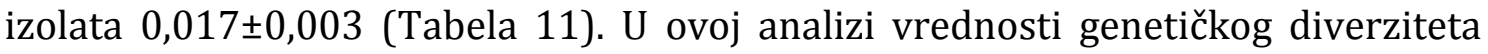
unutar PPV-M i PPV-Rec izolata je približna. Ovi rezultati su u potpunim saglasnostima sa ranijim istraživanjima genetičke strukture virusa šarke šljive u Srbiji (Jevremović, 2008; Jevremović et al., 2009).

Više autora navodi da populacije virusa koje pokazuju veću vrednost genetičkog diverziteta treba smatra starijim (Moya i Garcia-Arenal, 1995; Azzam et al., 2000; Glasa et al., 2007; Wei et al., 2009). Na bazi ovog stanovišta populaciju izolata koji pripadaju PPV-D soju u Srbiji treba smatrati starijom u odnosu na PPVM i PPV-Rec soj. PPV-D soj je prevalentan u okruzima koji se nalaze istočno od Velike i Južne Morave, a to su upravo lokaliteti gde je šarka po prvi put opisana u Srbiji (Josifović, 1941). Uzimajući u obzir sve ove navode, može se predpostaviti da je PPV-D soj „najstariji“ soj šarke prisutan Srbiji.

Podatak da je procenjena vrednost genetičkog diverziteta PPV-Rec izolata najniža, sugeriše da ovaj soj treba smatrati „najmlađim“ i da je on proizvod rekombinacije, kao što navode i Glasa et al., (2004). Neke pojave, kao što je genetičko usko grlo (genetic bootleneck), koje se javljaju nakon pojave rekombinacije, mogu uticati na ovaj način identifikacije „starijih“ i „mlađih“ izolata i sojeva (Glasa et al., 2004). Prolazak populacije kroz usko grlo smanjuje genetičku varijabilnost unutar populacije i povećava genetičke razlike u odnosu na druge populacije. Uzimajući u obzir i ove fenomene, moguć je i potpuno drugačiji scenario da je PPV-Rec soj „predak“, a da PPV-M ili PPV-D soj predstavljaju rekombinante koji potiču od pojave rekombinacije u NIb genu (Glasa et al., 2004, Glasa et al., 2005).

Vrednosti genetičkog diverziteta između klastera PPV-M, PPV-D i PPV-Rec izolata pokazuju više vrednosti $u$ odnosu na proračunati genetički diverzitet unutar pojedinih klastera PPV sojeva. Diverzitet između PPV-Rec i PPV-M izolata iznosi 6,7\%. Ovaj rezultat je u potpunoj saglasnosti sa tipom genoma rekombinantnih i PPV-M izolata nizvodno od tačke rekombinacije. Diverzitet između PPV-D i PPV-Rec, odnosno PPV-D i PPV-M je znatno veći i iznosi 25-27\%. 
Filogenetska analiza nukleotidnih sekvenci 46 PPV-Rec izolata iz Srbije sa još 160 dostupnih sekvenci PPV-Rec izolata iz drugih zemalja pokazala je da ne postoji specifično grupisanje izolata iz Srbije u odnosu na PPV-Rec izolate iz drugih zemalja (Slika 26). Procenjena vrednost genetičkog diverziteta u okviru svih PPVRec izolata iznosi 0,021 $\pm 0,003$. Ukoliko se posmatraju samo PPV-Rec izolati iz Srbije ova vrednost je nešto niža i iznosi $0,018 \pm 0,003$, dok je za izolate iz ostalih zemalja $0,022 \pm 0,003$. Ovaj rezultat je u potpunoj suprotnosti sa navodima koje su izneli Glasa et al., (2005) analizirajući 7 PPV-Rec izolata iz Srbije, gde je na bazi proračunatih vrednosti genetičkog diverziteta izneta hipoteza da je bivša Jugoslavija centar disperzije PPV-Rec izolata. Rezultati izneti u ovoj disertaciji pokazuju da je odstupanje u vrednosti genetičkog diverziteta PPV-Rec izolata iz Srbije u odnosu na izolate iz ostalih zemalja na nivou statističke greške $(0,004)$. Šta više, rekombinantni izolati iz Srbije pokazuju nižu vrednost genetičkog diverziteta u odnosu na ostale izolate, što je potpuno suprotan rezultat u odnosu na analizu malog broja uzoraka koji navode Glasa et al., (2005).

Rezultati analize PPV-Rec izolata prikazani u ovoj disertaciji potvrđuju da je za pouzdane statističke proračune i dobijanje pouzdanih rezultata potrebno analizirati veliki broj izolata. To dokazuju i rezultati analize genetičkog diverziteta PPV-M izolata iz Srbije (Tabele 10 i 11). Vrednost genetičkog diverziteta PPV-M izolata iz ove disertacije ( 3 izolata) je 0,012 $\pm 0,004$, dok je ta vrednost za 23 izolata $0,020 \pm 0,003$, što je statistički značajna razlika.

Analiza nukleotidnih sekvenci PPV-D izolata obuhvatala je 369 izolata, od čega 21 izolat iz Srbije. Kao i kod PPV-Rec izolata i kod filogenetske analize PPV-D izolata nema grupisanja izolata iz Srbije (Slika 27). Procenjena vrednost genetičkog diverziteta za izolate iz Srbije je 0,026 $\pm 0,006$. Vrednost genetičkog diverziteta za PPV-D izolate iz ostalih zemalja (348 izolata) je identična kao i vrednost genetičkog diverziteta svih analiziranih 369 PPV-D izolata i iznosi 0,031 0,006 (Tabela 13).

Ukoliko se uporede vrednosti genetičkog diverziteta, uočava se da je ova vrednost za PPV-D izolate značajno viša $(0,031 \pm 0,006)$ u odnosu na vrednost za PPV-Rec izolate $(0,021 \pm 0,003)$. PPV-D izolati su utvrđeni u svim zemljama gde je 
potvrđen virus šarke, dok su rekombinantni izolati utvrđeni u znatno manjem broju zemalja.

\subsubsection{Analiza nukleotidnih sekvenci P3-6K1 regiona}

Osim C-ter $\mathrm{NIb}-\mathrm{N}$-ter $\mathrm{CP}$ regiona genoma, kod svih odabranih izolata izvršeno je i sekvencioniranje fragmenta od 788 bp lociranog u C-ter P3, 6K1 i Nter CI regionu genoma.

N-ter CP, P1 i P3 su najvarijabilniji regioni genoma u okviru virusa iz roda Potyvirus, dok P3 region pokazuje najmanju varijabilnost između različitih sojeva jednog virusa (Aleman-Verdaguer et al., 1997). Upoređujući sekvence kompletnog genoma virusa šarke više autora je utvrdilo da su najvarijabiniji regioni genoma: N-ter CP, P1, P3 i C-ter HC (Palkovics et al., 1993; Myrta et al., 2006).

$\mathrm{Na}$ bazi dobijenih nukleotidnih sekvenci 41 izolata rekonstruisano je filogenetsko stablo koje jasno pokazuje tri klastera izolata koji odgovaraju PPV-M, PPV-D i PPV-Rec soju (Slika 28). Dobijeni rezultati su u saglasnosti sa rezultatima tipiziranja izolata IC-RT-PCR metodom i analizom sekvenci C-ter NIb-N-ter CP regiona genoma. Filogenetsko grupisanje izolata je nezavisno od analiziranog regiona genoma (Candresse et al., 1995; Glasa et al., 2002b). Različiti regioni genoma virusa šarke ponašaju se kao odvojene celine i razlike u sekvencama između sojeva su prisutne duž čitavog genoma, iako vrednosti genetičkog diverziteta u okviru različitih regiona nisu jednake (Glasa et al., 2002b).

Vrednost genetičkog diverziteta u okviru PPV-Rec izolata je najviša 0,020 $\pm 0,002$, nešto manja u okviru PPV-D izolata $0,013 \pm 0,002$, a najmanja u okviru PPV-M izolata 0,006 $\pm 0,002$ (Tabela 14).

U analizi 69 PPV izolata iz Srbije (35 PPV-Rec, 18 PPV-D i 26 PPV-M izolata) dobijeni su analogni rezultati (Slika 29). Najvišu vrednost genetičkog diverziteta pokazuje klaster PPV-Rec izolata 0,019 $\pm 0,002$, sledi klaster PPV-D izolata $0,015 \pm 0,002$ i na kraju klaster PPV-M izolata $0,006 \pm 0,001$ (Tabela 15). U ovom analiziranom regionu genoma klaster PPV-M izolata pokazuje najnižu vednost genetičkog diverziteta koja je 2,5-3 puta niža u odnosu na PPV-D i PPV-Rec izolate. 
Kao što je i očekivano, vrednosti genetičkog diverziteta između klastera PPV-M, PPV-D i PPV-Rec izolata pokazuju više vrednosti u odnosu na proračunati genetički diverzitet unutar pojedinih klastera PPV sojeva. Diverzitet između PPVRec i PPV-D izolata iznosi 3,0\%. Diverzitet između PPV-M i PPV-D, odnosno PPV-M i PPV-Rec je gotovo isti i iznosi 15,3-15,5\%.

Filogenetska analiza P3-6K1 sekvenci 131 PPV-Rec izolata iz 12 zemalja (uključujući Srbiju) pokazala je izvesno grupisanje većine PPV-Rec izolata iz Srbije sa nekim izolatima iz Bosne i Hercegovine (Slika 30). Ovo grupisanje nije podržano visokim bootstrap vrednostima. Grupisanje izolata iz ostalih zemalja je takođe prisutno, ali bez visokih bootstrap vrednosti (osim za pojedine izolate iz Italije i Bugarske). Vrednost genetičkog diverziteta za izolate iz Srbije, kao i za izolate iz ostalih zemalja je identično $(0,018 \pm 0,002)$ i ne daje preciznije objašnjenje parcijalnog grupisanja izolata.

Filogenetska analiza P3-6K1 sekvenci 224 PPV-D izolata iz preko 20 zemalja pokazala je posebno grupisanje gotovo svih izolata iz Srbije (osim izolata RS-46pl, RS-59pl i RS-60pl) među kojima se nalazi i jedan izolat iz Slovačke (SK-226pl) (Slika 31). Bootstrap vrednost za ovu grupu izolata je svega 34\%. Kao opšte pravilo, ukoliko je bootstrap vrednost za zadatu granu filogenetskog stabla 95\% ili viša, onda se topologija te grane smatra ispravnom (Nei i Kumar, 2000). U brojnim filogenetskim analizama koje se sprovode u virusologiji, bootstrap vrednost koja je $75 \%$ ili viša smatra se značajnom. Vrednost genetičkog diverziteta za izolate iz Srbije, kao i za izolate iz ostalih zemalja je identična $(0,014 \pm 0,002)$.

Delimično grupisanje PPV-Rec i PPV-D izolata koje se uočava na rekonstruisanim filogenetskim stablima od 723 bp fragmenta iz C-ter P3, 6K1 i Nter CI regiona (Slike 30 i 31) uslovljeno je pre svega manjom varijabilnošću unutar ovog regiona genoma virusa šarke u odnosu na N-ter CP region. 


\subsection{Dinamika širenja sojeva šarke šljive, prisustvo i brojnost lisnih vaši u eksperimentalnom zasadu šljive}

Pionirska istraživanja prostornog i vremenskog širenja virusa šarke na šljivi kod nas je započeo Jordović još pre 60 godina i bila su bazirana uglavnom na ekspresiji simptoma (Jordović, 1965, 1975, 1976). U vreme ovih istraživanja, kada sojevi šarke nisu bili poznati i kada je dominantna sorta u našim voćnjacima bila Požegača, primenjivan je samo vizuelni metod inspekcije stabala u zasadu koji ne može da pruži sliku širenja pojedinih izolata (Jordović, 1975). U dvadesetogodišnjem istraživanju širenja virusa šarke u zasadu Požegače, Jordović je utvrdio je da su u prve dve godine ispitivanja zaražena stabla u zasadu bila nasumično locirana u zasadu bez ikakve regularnosti, što je ukazivalo da zaraza uglavnom potiče iz eksternih izvora. U narednim godinama, novozaražena stabla su skoncentrisana oko stabala koja su zaražena u prethodnim godinama. Slične rezultate širenja virusa šarke u kasnijim godinama infekcije navode Paunović et al., (2008) tokom ispitivanja brzine širenja virusa šarke u zasadu šljive sorte Čačanska rodna.

Ispitivanja prostornog $\mathrm{i}$ vremenskog širenja virusa šarke šljive su sprovedena u zasadima kajsije, breskve i šljive u Španiji, Francuskoj, Grčkoj i Češkoj (Llácer et al., 1992; Gotwald et al., 1995; Dicenta et al., 1999; MartínezGómez et al., 2003; Dallot et al., 2004; Varveri et al., 1999; Blazek et al., 2003). Međutim, agroekološki uslovi, prisustvo i rasprostranjenost sojeva, kao i epidemiološka situacija u ovim zemljama su potpuno drugačiji od uslova u Srbiji.

Ispitivanja u eksperimentalnom zasadu šljive koja su sprovedena tokom izrade ove disertacije predstavljaju prva istraživanja praćenja brzine širenja pojedinih sojeva virusa šarke bazirana na analizi sekvenci i izradi rodoslovne povezanosti izolata detektovanih u zaraženim stablima. Sprovedeni eksperiment obuhvatao je kompleksnu primenu više metoda detekcije i karakterizacije virusa šarke. Pored nezaobilaznih vizuelnih pregleda, sprovedeni su serološki ELISA test i molekularna IC-RT-PCR metoda. Sekvencioniranjem dela genoma detektovanih 
izolata i analizom sekvenci, primenom više softvera baziranih na različitim statističkim modelima omogućeno je praćenje prostornog i vremenskog širenja pojedinačnih izolata.

Prilikom planiranja eksperimenta sa ciljem utvrđivanja intenziteta širenja i kompeticije PPV-D i PPV-Rec sojeva u zasadu šljive, idealna lokacija za podizanje eksperimentalnog zasada bila bi potpuno izolovana parcela bez Prunus vrsta $\mathrm{u}$ bližoj i daljoj okolini. Na taj način, širenje izolata sa inokulisanih stabala ne bi bilo ometano iz eksternih izvora. U našoj zemlji, gde je virus šarke endemično prisutan, veoma je teško naći takav lokalitet. U nekim regionima (Vojvodina) postoje ovakvi izolovani lokaliteti gde se na velikim površinama gaje ratarske kulture. Međutim, u ovakvoj sredini problem bi bilo prisustvo/odsustvo populacija određenih vrsta lisnih vaši koje su opisane kao vektori šarke, čije je prisustvo esencijalno za sprovođenje eksperimenta.

Lokalitet koji je odabran za podizanje eksperimentalnog zasada nalazi se $\mathrm{u}$ selu Ostra kod Čačka, u Moravičkom okrugu, na lokalitetu sa idealnim agroekološkim uslovima za gajenje šljive. „Otežavajuća“ okolnost pri izboru lokacije predstavljala su zaražena stabla koja se nalaze u okolini zasada. Iz tog razloga, sva stabla koja se nalaze u neposrednoj blizini zasada su uključena u istraživanje i analizirana su zajedno sa svim stablima u eksperimentalnom zasadu. Uslovi koji su vladali tokom eksperimenta predstavljaju realne uslove (endemična raširenost virusa šarke šljive) u kojima se gaji šljiva i ostale Prunus vrste u Srbiji.

Obzirom da je zasad lociran u regionu sa velikim brojem stabala šljive, kajsije i ostalih domaćina šarke nesumnjivo je da su lisne vaši prisutne, a naročito vrste koje su opisane kao vektori. Radi potvrde ove pretpostavke, tokom poslednje tri godine istraživanja, praćena je dinamika brojnosti populacija lisnih vaši koje su posećivale eksperimentalni zasad.

\subsubsection{Ispitivanje prisustva virusa šarke u eksperimentalnom zasadu u prvoj godini istraživanja (2008. godina)}

Ispitivanja u prvoj godini istraživanja imala su za cilj proveru zdravstvenog statusa posađenih sadnica i ispitivanje biljaka iz okoline zasada - potencijalnih 
izvora infekcije. Tokom vizuelnih pregleda i sprovedenog ELISA testa ni u jednom stablu u zasadu nije utvrđeno prisustvo virusa šarke šljive. Ukoliko se za podizanje zasada koristi zaražen sadni materijal, simptomi se u najvećem broju slučajeva na posađenim biljkama javljaju odmah u prvoj godini. Međutim, zaraza može biti latentna i više godina (najčešće 3 godine), a da nakon tog perioda dođe do pojave prvih simptoma. To potvrđuju i rezultati ispitivanja sadnica kajsije i breskve koje su prikazali Quiot et al., (1995).

U okolini eksperimentalnog zasada su na početku ogleda locirana dva potencijalna eksterna izvora infekcije na razdaljini od $40 \mathrm{~m}$ (2 zaražena stabla) i 70 m (11 zaraženih od ukupno 38 stabala). Obzirom da se radi o stablima šljive koja su starosti 5 godina i koja imaju veliku lisnu masu, ona predstavljaju značajan izvor inokuluma koji se lisnim vašima može preneti u eksperimentalni zasad. Strukturu inokuluma čine 3 PPV-D i 8 PPV-Rec izolata u malom zasadu šljive, tako da je na početku eksperimenta odnos PPV-D:PPV-Rec (eksterni izvor infekcije) u malom zasadu jednak 1:2,67. Uzimajući u obzir i 2 stabla Crvene ranke odnos PPV-D:PPVRec u neposrednoj okolini eksperimentalnog zasada je 1:3,3.

Izbor izolata za inokulaciju je sproveden analizom sekvenci C-ter NIb-N-ter CP regiona genoma PPV izolata iz okoline eksperimentalnog zasada i više PPV-D i PPV-Rec izolata - potencijalnih inokuluma. Za inokulaciju su odabrana dva izolata (RS-67pl i RS-68pl) koji se od svih ostalih izolata iz okoline zasada razlikuju u 5, odnosno 2 fiksne mutacije (prilozi 2 i 3). Istraživanja epidemioloških osobina odabranih izolata u kontrolisanim uslovima, koja su pokazala visoku efikasnost prenošenja oba izolata na šljivu, kajsiju i breskvu lisnim vašima Myzus persicae Sulz., potvrđuju da su odabrani adekvatni izolati za ovaj ogled (Gerard Labonne $i$ Sylvie Dallot, lična komunikacija).

Inokulacija odabranih biljaka je uspešno sprovedena, što je potvrđeno proverom prijema kalemljenja, tako da je u eksperimentalnom zasadu odnos PPVD:PPV-Rec inokuluma (interni izvor infekcije) na početku eksperimenta 1:1. 


\subsubsection{Ispitivanje prisustva $i$ distribucije virusa šarke $u$ eksperimentalnom zasadu u drugoj godini istraživanja (2009. godina)}

Vizuelnim pregledom biljaka u drugoj godini istraživanja utvrđeni su simptomi virusa šarke na listovima svih 8 inokulisanih biljaka, kao i na još tri stabla $(3 / 3,12 / 7$ i 15/7). Simptomi na svim stablima su bili lokalizovani na jednoj ili dve skeletne grane i jasno izraženi. ELISA testom je potvrđeno prisustvo virusa šarke u svim stablima koja su pokazivala simptome.

Karakterizacija sojeva urađena je IC-RT-PCR testom i dopunjena je analizom sekvenci C-ter NIb-N-ter CP regiona genoma. Upoređivanjem sekvenci detektovanih izolata sa sekvencama inokuluma utvrđeno je da nijedno od tri novozaražena stabla nije zaraženo izolatom koji potiče sa inokulisanih stabala (Prilozi 4 i 5). Ovakav rezultat je očekivan, jer su odgovarajuća stabla inokulisana prethodne godine i neophodan je izvestan period za umnožavanje virusa $u$ domaćinu, da se razviju simptomi i biljka postane značajan izvor inokuluma.

Analiza sekvenci dva PPV-Rec izolata sa novozaraženih stabala (12/7_09 i 15/7_09) i izolata iz okoline eksperimentalnog zasada pokazala je da su novoutvrđeni izolati veoma slični PPV-Rec izolatima 4/2exter, 4/11exter i RS-24pl. Ova tri izolata predstavljaju ustvari jedan isti izolat koji je utvrđen u tri stabla u okolini eksperimentalnog zasada. Izolat 15/7_09 pokazuje samo $1 \mathrm{nt}$ razlike u odnosu ove eksterne izolate, dok se izolat 12/7_09 razlikuje u 3 nt (Slika 33).

U jednom zaraženom stablu koegzistira veliki broj sekvencionih varijanti istog izolata, odnosno prisutan je značajan genetički diverzitet virusa šarke unutar domaćina (Uridi et al., 2006; Predajna et al., 2012). Sekvencioni varijanti mogu biti različito distribuirani u stablu, a njihov diverzitet se povećava idući od osnove stabla (deblo) ka najmlađim organima (listovi i plodovi) (Jridi et al., 2006). Pri uzorkovanju stabala u eksperimentalnom zasadu, kao i u njegovoj okolini, uzorci listova su uzimani sa svih delova krune. Na taj način detektovan je dominantan varijant izolata koji je prisutan u stablu. Ova činjenica je od posebnog značaja pri analizi izolata iz malog zasada šljive. Ova stabla su na početku eksperimenta bila 
starosti 5 godina i sistemično zaražena virusom šarke. Pri prenošenju virusnih čestica na zdrava stabla, lisne vaši su na neperzistentan način prenele upravo onaj sekvencioni varijant koji je prisutan u listu na kome se lisna vaš hranila ili samo izvršila probne ubode koji su dovoljni da virus dospe u stilet. Uzimajući u obzir sve ove navode, sa velikom verovatnoćom se može tvrditi da izvor zaraze stabala 12/7 i 15/7 predstavljaju stabla sorte Stenley 4/2, 4/11 iz obližnjeg malog zasada šljive ili stablo Crvene ranke (RS-24pl) (Slika 18, šema 2).

Analizirani PPV-D izolati pokazuju znatno veću divergentnost. Novootkriveni izolat 3/3_09 ne potiče sa inokulisanih stabala (13 nt razlike), niti sa stabala iz obližnjeg malog zasada (po 19 nt razlike) (Slika 34). Postoje dva moguća izvora zaraze ovim PPV-D izolatom. Prvi, da je stablo 3/3 bilo latentno zaraženo sa PPV (zaražen sadni materijal), pri čemi je infekcija bila lokalizovana koja nije utvrđena ELISA testom, a simptomi su se ispoljili tek nakon godinu dana. I drugi, da izvor zaraze potiče sa nekog nepoznatog stabla koje se nalazi na većoj udaljenosti od eksperimentalnog zasada. Pojava prenošenja PPV na veće udaljenosti odavno je poznata, a to potvrđuju i istraživanja u Francuskoj (Labonne $i$ Dallot, 2006).

Ispitivanje prisustva vrsta i brojnosti lisnih vaši koje su posećivale eksperimentalni zasad pokazuje značajna kolebanja brojnosti populacija lisnih vaši tokom vegetacionog perioda. Jasno su izražena dva pika brojnosti (prolećni i jesenji), pri čemu je brojnost vrsta koje su opisane kao vektori gotovo dvostruka u prolećnom, negu u odnosu na jesenji pik (Grafikon 7). Tokom 2009. godine najveću brojnost su imale vrste iz roda Aphis, koje su značajni vektori PPV.

\subsubsection{Ispitivanje širenja virusa šarke u eksperimentalnom zasadu u trećoj godini istraživanja (2010. godina)}

U trećoj godini istraživanja utvrđeno je 20 stabala sa simptomima PPV. Ocena simptoma je varirala od 1-4, odnosno od stabala sa 2-3 lista sa simptomima, do stabala sa simptomima na listovima na kompletnoj kruni. Iako je 
do zaraze većine stabala došlo $\mathrm{u}$ prethodnoj godini postoji velika varijabilnost $\mathrm{u}$ intenzitetu i izgledu simptoma (Tabela 21). Ova varijabilnost nije uslovljena sortom jer se radi o istoj sorti (Čačanska lepotica), niti sojem virusa (Tabela 22).

U odnosu na 2009. godinu kada su utvrđena samo 3 stabla zaražena sa PPV, tokom 2010. godine je utvđeno još 17 novozaraženih stabala, što ukupno čini 5\% od svih biljaka u zasadu. Od 20 stabala, kod 2 je utvrđen PPV-D, a kod 18 PPV-Rec soj. U odnosu na prethodnu godinu broj stabala zaraženih PPV-D sojem povećan je 2 puta, dok je broj stabala sa PPV-Rec sojem uvećan 9 puta.

Analiza sekvenci C-ter $\mathrm{NIb}-\mathrm{N}$-ter $\mathrm{CP}$ regiona genoma novozaraženih stabala i sekvenci izolata inokuluma pokazuje da nijedno od novozaraženih stabala nije zaraženo izolatom sa inokulisanih stabala (Prilozi 7 i 8).

Analiza sekvenci PPV-Rec izolata sa novozaraženih stabala i izolata iz okoline eksperimentalnog zasada ukazuje na postojanje divergentnosti detektovanih izolata (Slika 36). TCS analiza ukazuje na povezanost nt sekvenci izolata i nekoliko mogućih izvora infekcije. Izolat 15/15_10 ima 100\% identičnu nukleotidnu sekvencu sa izolatima 2/8exter i 4/13exter što nesumnjivo potvrđuje da potiče sa nekog od ova dva stabla. Izolati 7/20_10 i 6/17_10 imaju samo 1 nt razlike u odnosu na navedene izolate, što navodi na zaključak da takođe potiču sa istih ovih stabala. U pogledu divergentnosti, ovim izolatima iz eksternog izvora bliski su i izolati 6/1_10,6/27_10 (5 nt razlike), 16/8_10 (6 nt razlike), a najveću divergentnost pokazuje izolat 7/1_10 (7 nt razlike).

Izolati 15/3_10,6/23_10, 10/24_10, 13/20_10 i 14/25_10 pokazuju 4 nt razlike; izolat 10/11_10 $5 \mathrm{nt}$ razlike; a izolat 5/2_10 $6 \mathrm{nt}$ razlike u odnosu na izolate 4/2exter, 4/11exter i RS-24pl što ukazuje da svi ovi izolati mogu poticati sa ovih stabala iz okoline eksperimentalnog zasada.

Izolati 5/29_10 i 12/18_10 pokazuju 3, odnosno 5 nt razlike u odnosu na izolat 3/9exter, što ga označava kao mogući izvor infekcije.

PPV-D izolati iz eksperimentalnog zasada i iz eksternih izvora pokazuju visoku divergentnost. Izolat 3/21_10 pokazuje 16 nt razlike u odnosu na izolate 4/4exter, 4/9exter i 4/12 exter. Kao i izolat 3/3_09, koji je utvrđen prethodne 
godine, ne postoji značajna povezanost izolata 3/21_10 sa izolatima iz eksternog izvora, kao ni sa sekvencom izolata inokuluma.

Tokom 2010. godine zabeležena je nešto veća brojnost uhvaćenih krilatih formi lisnih vaši u odnosu na prethodnu godinu. Međutim, brojnost vrsta koje su opisane kao vektori je znatno niža u odnosu na 2009. godinu (Grafikon 8). Pik brojnosti svih vrsta bio je u prvoj dekadi juna (prolećni pik) zahvaljujući velikoj brojnosti vrsta roda Myzocallis, naročito vrste $M$. boerneri čiji je domaćin hrast, a koja nije opisana kao vektor PPV.

\subsubsection{Ispitivanje dinamike širenja i prostorne distribucije virusa šarke u eksperimentalnom zasadu u četvrtoj godini istraživanja (2011. godina)}

U poslednjoj godini istraživanja u eksperimentalnom zasadu utvrđeno je ukupno 37 zaraženih stabala (ne računajući 8 inokulisanih), što predstavlja povećanje broja zaraženih stabala od 85\% u odnosu na prethodnu godinu. U 2011. godini kod ukupno 9,25\% stabala u zasadu utvrđen je PPV.

U vizuelnim pregledima, kao i u 2010. godini, ocena simptoma je varirala od 1-4, odnosno od stabala sa 2-3 listova sa simptomima do stabala sa simptomima na kompletnoj kruni. Pored uobičajenih simptoma koji su do sada primećeni na listovima šljive (mozaik i prstenaste pege), po prvi put su na pojedinim stablima primećeni simptomi u vidu prosvetljavanja nerava. Prisutna je velika varijabilnost u intenzitetu simptoma, ali su na najvećem broju stabala primećeni blagi do jaki simptomi (ocena 2-3) (Tabela 23). Obzirom na visoke temperature koje su bile prisutne tokom čitave vegetacije, simptomi su tokom jula i avgusta bili teško uočljivi na stablima gde je primećena izrazito lokalna infekcija (par listova sa simptomima).

Strukturu detektovanih izolata čini 5 PPV-D izolata i 32 PPV-Rec izolata. U odnosu na prethodnu godinu broj stabala zaraženih PPV-D sojem povećan je 2,5 puta, dok je broj stabala zaraženih PPV-Rec sojem uvećan 1,8 puta. Ukoliko se 
uporedi broj zaraženih stabala sa 2009. godinom, broj stabala zaraženih PPV-D sojem povećan je 5 puta, a broj stabala zaraženih PPV-Rec sojem povećan je 16 puta.

U 2011. godini analizom stabala iz malog zasada šljive utvrđeno je prisustvo 4 stabla zaraženih PPV-D sojem i 17 stabala zaraženih PPV-Rec sojem. Broj zaraženih biljaka u malom zasadu se u periodu 2008-2011. godina povećao 1,9 puta. Ovim povećanjem izmenjen je i odnos PPV-D:PPV-Rec u malom zasadu sa 1:2,67 u 2008. godini, na 1:4,25 u 2011. godini. Ukoliko se u analizu uključe i 2 stabla Crvene ranke odnos PPV-D:PPV-Rec (eksterni izvor infekcije) je 1:4,75.

Interni izvor infekcije, koji predstavljaju inokulisana stabla PPV-D i PPV-Rec izolatima je tokom čitavog eksperimenta ostao nepromenjen 1:1. U eksperimentalnom zasadu je u 2011. godini utvrđeno 5 PPV-D izolata i 32 PPV-Rec izolata, što predstavlja odnos 1:6,4. Upoređujući podatke o broju zaraženih stabala PPV-D i PPV-Rec sojem u eksperimentalnom zasadu i njegovoj okolini primećuje se nešto efikasnije širenje PPV-Rec soja u odnosu na PPV-D soj tokom trajanja ogleda. Za donošenje konačnog zaključka o „superiornosti“ PPV-Rec soja u pogledu brzine širenja u odnosu na PPV-D soj u našim agroekološkim uslovima neophodno je sprovesti još nekoliko godina istraživanja, što je planirano i nakon izrade ove disertacije. Podaci o raširenosti sojeva virusa šarke u zasadima šljive u Srbiji koji su izneti u prvom delu rezultata disertacije, idu u prilog „superiornosti“ PPV-Rec soja koji ima skoro dvostruko veću zastupljenost $\mathrm{u}$ analiziranim zasadima $\mathrm{u}$ odnosu na PPV-D soj.

TCS analiza svih sekvenci PPV-Rec izolata iz eksperimentalnog zasada, njegove okoline i izolata inokuluma detaljno pokazuje povezanost sekvenci sa tačnim pozicijama mutacionih promena između izolata (Slika 38).

Po prvi put je u eksperimentalnom zasadu utvrđen izolat sa sekvencom bliskom izolatu inokuluma. Sekvenca izolata 11/20_11 se razlikuje u samo 4 nt od sekvence PPV-Rec inokuluma RS-67pl. Ono što potvrđuje da izolat 11/20_11 potiče sa inokulisanih stabala je posedovanje A na poziciji 183 i T na poziciji 188 (Prilog 10), što je upravo bila osnova za razlikovanje PPV-Rec izolata inokuluma od svih 
ostalih izolata iz okoline eksperimentalnog zasada. Svi ostali PPV-Rec izolati poseduju T na poziciji 183 i C na poziciji 188.

Analiza pokazuje da je došlo i do sekundarnog širenja izolata u zasadu. Izolat koji je utvrđen na stablu $10 / 8$ potiče sa stabla $12 / 7$ kod koga je zaraza utvrđena 2009. godine, dok je na stablu 10/9 potvrđen izolat sa stabla 15/15 koji je potvrđen u 2010. godini. TCS analiza je takođe pokazala visoku identičnost nekoliko nukleotidnih sekvenci PPV-Rec izolata iz 2011. godine i 2010. godine. Sekvence izolata 7/8_11,8/8_11 i 15/1_11 pokazuju samo 2-4 nt razlike u odnosu na izolate 15/3_10, 13/20_10,6/23_10, 10/24_10 i 10/11_10 iz 2010. godine, što je za 2-4 nt manje u odnosu na sličnost sa nekim izolatima iz okoline eksperimentalnog zasada. Takođe, sekvenca izolata 13/25_11 se razlikuje samo u 2 nt u odnosu na sekvencu izolata 16/8_10, a sekvenca izolata 7/3_11 u 3 nt od sekvence 12/7_09. Ova konstatacija navodi na zaključak, da infekcija kod ovih stabala koja je utvrđena 2011. godine, potiče od stabala iz samog zasada koja su zaražena u prethodne dve godine. U prilog ovoj konstataciji ide i podatak da su sva navedena stabla tokom 2010. godine bila sistemično zaražena i predstavljala odličan izvor inokuluma (Tabela 21).

TCS analiza takođe pokazuje nekoliko mogućih izvora infekcije ostalih novozaraženih stabala u eksperimentalnom zasadu. Sekvence izolata 4/10_11 i 8/4_11 se razlikuju u samo 1 nt $\mathrm{u}$ odnosu na novootkriveni izolat 4/7exter iz malog zasada šljive, što navodi na zaključak da je on izvor infekcije ovih stabala. Sekvenca izolata 5/2_11 pokazuje 4 nt razlike u odnosu na izolate 4/10_11 i 8/4_11, odnosno 5 nt razlike u odnosu na sekvencu njihovog izvora zaraze 4/7exter. Sekvenca izolata 10/22_11 je bliska sekvencama izolata 3/8exter, 4/2exter, 4/11exter i RS-24pl iz okoline eksperimentalnog zasada (6 nt razlike). Sekvenca izolata 10/28_11 je bliska sekvencama 2/3exter, 2/4exter, 2/8exter i 4/13exter iz malog zasada šljive (4 nt razlike). Sekvence izolata 4/10_11,8/4_11 i 5/5_11 pokazuju 6 nt razlike u odnosu na navedene eksterne izolate.

U TCS analizi sekvenci PPV-D izolata iz eksperimentalnog zasada, njegove okoline i inokuluma, jasno se uočava viša varijabilnost sekvenci nego što je to slučaj sa PPV-Rec izolatima (slike 37 i 38). Nijedan od izolata iz eksperimentalnog 
zasada ne potiče sa inokulisanih stabala. Najbliža konekcija sekvenci PPV-D izolata postoji između izolata kod stabala 3/21 i 13/3. Sekvence ovih izolata se razlikuju u 4 nt. Infekcija stabla 3/21 je potvrđena 2010. godine i simptomi su bili prisutni gotovo na čitavoj kruni stabla. Infekcija kod stabla 13/3 je potvrđena 2011. godine, što navodi na predpostavku da je njegov izvor zaraze stablo 3/21. Takođe, sličnost nukleotidnih sekvenci pokazuju i sekvence izolata 9/29_11 i 4/4exter (6 nt razlike). Sekvence ostalih izolata (3/3_09 i 3/19_11) iz eksperimentalnog zasada pokazuju veliku divergentnost u odnosu na sve ostale izolate. Sekvence izolata 3/21_10 i 3/19_11 pokazuju veliku divergentnost (15 nt razlike), iako se stabla nalaze na udaljenosti od svega $9 \mathrm{~m}$.

Visoke stope mutacija RNK virusa jesu posledica potrebe brze replikacije njihovog hemijski nestabilnog RNK genoma, pre nego evolutivna strategija (Drake $i$ Holland, 1999). Visoka stopa mutacija koja se dešava pri replikaciji RNK virusa je osnovni izvor varijacija u populaciji virusa u nekom lokalitetu/oblasti ili u samom domaćinu. U svom radu, Predajna et al., (2012) navode značajnu intra-izolat varijabilnost koja je utvrđena u stablu šljive starosti 7 godina. Od 105 pojedinačnih PPV-M sekvenci utvrdili su postojanje 51 haplotipa, a najveća varijabilnost je utvrđena u listovima, gde maksimalna razlika u sekvenci haplotipova iznosi 9 nt. Sličan rezultat navode i Jridi et al., (2006), gde je u stablu breskve (starosti 13 godina zaraženom PPV-M izolatom) utvrđeno 33 haplotipova sa maksimalnom razlikom sekvenci od $15 \mathrm{nt}$. U oba rada, u rekonstruisanim mrežama povezanosti haplotipova primenom TSC programa prisutni su i nedostajući (hipotetički) haplotipovi. Genetički diverzitet PPV-D i PPV-Rec sojeva u jednom stablu do sada nije opisan u literaturi. Obzirom na postojanje značajne intra-izolat varijabilnosti virusa koji se na neperzistentan prenosi lisnim vašima, veoma je teško decidno utvrditi egzaktne puteve prostornog širenja pojedinačnih izolata. Još uvek ne postoje podaci o ispitivanjima divergentnosti sekvenci izolata domaćina i divergentnosti sekvenci zaražene biljke Prunus vrste, koja je zaražna putem lisnih vaši u kontrolisanim uslovima.

Istraživanja koja su sprovedena u eksperimentalnom zasadu šljive su pokazala da osnovni izvor zaraze u prvim godinama od zasnivanja zasada 
predstavljaju zaražena stabla koja se nalaze u okolini zasada, što potvrđuje navode Jordovića (1975). Novozaražena stabla su nasumično raspoređena po zasadu bez ikakvog pravila, što je uslovljeno samim letom lisnih vaši. U četvrtoj godini po sadnji je došlo do pojave sekundarnih infekcija u zasadu, odnosno prenošenja zaraze sa stabala koja su zaražena u prethodnim godinama. Sa vegetativnim porastom stabala lisna masa se znatno povećava i predstavlja ogroman izvor inokuluma, naročito kod sistemično zaraženih stabala. Hraneći se, a što je još značajnije vršeći probne ubode, lisne vaši prenose virus šarke na stabla u zasadu ili van njega. Gotwald et al., (1995) navode da lisne vaši, koje u stiletu nose virus šarke radije sleću na stabla breskve koja su nešto udaljenija, nego na susedna stabla u zasadu. Pojava sekundarnih infekcija je potvrđena tokom izrade ove disertacije, ali one ne potiču sa stabala koje se nalaze u neposrednoj blizini, već sa nešto udaljenijih stabala. Rezultati ove disertacije takođe pokazuju, da do veoma efikasnog prenošenja PPV-Rec i PPV-D sojeva virusa putem lisnih vaši dolazi iz susednog voćnjaka koji se nalazi na $70 \mathrm{~m}$ od ispitivanog zasada, što je u skladu sa novodima Labonne i Dallot (2006).

Brojnost uhvaćenih lisnih vaši primenom Sticky-shoot metode je tokom 2011. godine bila na izrazito niskom nivou, 2 puta niža u odnosu na 2009. godinu i 4 puta niža u odnosu na 2010. godinu. Pikovi brojnosti nisu bili jasno izraženi kao prethodnih godina (Grafikon 9).

Tokom sve tri godine ispitivanja utvrđen je veliki broj vrsta vrsta lisnih vaši koje se javljaju na šljivi (prilozi 6, 9 i 13), znatno više nego u navodima PetrovićObradović (2003). Ispitivanja su pokazala da su vrste iz roda Aphis (A. craccivora Koch., A. spiraecola Pag., A. fabae Scop., i A. gossypii Glover) najbrojnije vrste lisnih vaši koje posećuju zasad šljive (uzimajući u obzir samo vektore). Osim ovih vrsta, u manjem procentu je potvrđeno i prisustvo: Brachycaudus helichrysi Kalt., B. cardui L., Hyalopterus pruni Geofrr., Macrosiphum rosae L., Metopolophium dirhodum Walk., Myzus persicae Sulz., Phorodon humuli Schr. i Rhopalosiphum padi L. Sve navedene vrste su u literaturi opisane kao prenosioci virusa šarke. Iako prikazani rezultati prikazuju niske brojčane vrednosti uhvaćenih lisnih vaši $u$ eksperimentalnom zasadu, treba imati u vidu da su one uhvaćene na samo 40 
listova u celom zasadu. Prema procenama koje se navode u literaturi, jedno stablo u toku godine poseti između 50.000 i 300.000 lisnih vaši (loc. cit. Gianessi et al., 2002).

Tretiranje zasada pesticidima rešava problem vaši koje su u zasadu, ali one jedinke koje u zasad dolete iz okoline potencijalno i jednim probnim ubodom mogu preneti virus. Redovna primena pesticida smanjuje brojnost lisnih vaši u zasadu, ali nema velikog uticaja na sprečavanje širenja virusa šarke šljive (Labonne Gerard, Dallot Sylvie i Candresse Thierry, lična komunikacija).

Osim teoretskog značaja, prikazani rezultati ispitivanja brojnosti populacija lisnih vaši imaju i praktični značaj, jer mogu poslužiti za planiranje optimalnih rokova primene pesticida u cilju njihovog suzbijanja. 


\section{ZAKLJUČAK}

Rezultati prikazani u uvoj disertaciji donose nova saznanja o rasprostranjenosti PPV-D i PPV-Rec sojeva virusa šarke šljive u zasadima šljive i kajsije u Srbiji, kao i osnovnim karakteristikama širenja ovih sojeva u zasadu šljive u početnim godinama infekcije.

Istraživanja su potvrdila široku rasprostranjenost virusa šarke u ispitivanim regionima gajenja koštičavih voćaka. Zahvaljujući primenjenoj metodologiji izvršena je uspešna karakterizacija prisutnih sojeva u ispitivanim uzorcima.

Kod obe ispitivane gajene kulture (šljiva i kajsija) potvrđeno je prisustvo sva tri soja virusa šarke. U više od polovine ispitivanih uzoraka $(55,7 \%)$ utvrđeno je prisustvo PPV-Rec soja, pa se obzirom na strukturu gajenja koštičavog voća kod nas, može zaključiti da je rekombinantni soj najrasprostranjeniji soj virusa šarke u Srbiji.

U Srbiji su kod šljive značajno rašireni PPV-Rec $(53,5 \%)$ i PPV-D $(27,9 \%)$ sojevi, dok je PPV-M soj utvrđen kod svega 5,4\% uzoraka. Kod šljive je utvrđen i značajan procenat mešanih infekcija (13,2\%), gde dominiraju uzorci istovremeno zaraženi PPV-D i PPV-Rec sojem. Po prvi put je potvrđeno prisustvo PPV-M, PPV-D i PPV-Rec soja u jednom stablu u prirodi.

U relativno malom ispitivanom broju uzoraka kajsije dominantno je utvrđeno prisustvo PPV-Rec soja (85\%), što potvrđuje dobru adaptabilnost rekombinantnog soja ovoj Prunus vrsti. 
Analiza geografske rasprostranjenosti sojeva pokazala je da je u centralnim i zapadnim delovima Srbije dominantno prisutan PPV-Rec soj, dok u jugoistočnim delovima dominira PPV-D soj.

Sprovedena filogenetska i analiza genealoške povezanosti sekvenci je pokazala da su ispitivani izolati tipični predstavnici odgovarajućeg soja i da ne postoji povezanost srodnih sekvenci sa geografskim poreklom izolata niti sa vrstom domaćina. Uzrok ovakvih rezultata filogeografske analize se može objasniti nekontrolisanim širenjem izolata putem zaraženog sadnog materijala u ranijem višegodišnjem periodu.

Zahvaljujući kompleksnoj primeni vizuelnih pregleda, seroloških i molekularnih testova, koji su dopunjeni analizom sekvenci hipervarijabilnog regiona genoma PPV i genealoškom analizom, dobijeni su podaci o karakteristikama širenja PPV-Rec i PPV-D sojeva šarke u eksperimentalnom zasadu šljive.

Ispitivanja su pokazala da do zaraze stabala u novozasnovanim zasadima najpre dolazi putem prenošenja virusa lisnim vašima sa okolnih zaraženih stabala, i pored postojanja izvora infekcije u samom zasadu. U novopodignutom zasadu utvrđena su stabla zaražena PPV-Rec i PPV-D izolatima virusa šarke iz okolnog zaraženog zasada, ali i sa nepoznatih stabala u okolini. U periodu od 4 godine, lisnim vašima je zaraženo 9,25\% od ukupnog broja biljaka u zasadu.

Do pojave sekundarnih infekcija u zasadu dolazi u kasnijim godinama, sa vegetativnim porastom stabala i sistemičnom infekcijom, ali bez pravilnosti $u$ lokaciji novozaraženih stabala u odnosu na izvor infekcije.

U četvrtoj godini po sadnji u eksperimentalnom zasadu je kod 5 stabala utvrđen PPV-D soj, a kod 32 stabla PPV-Rec soj. Uzimajući u obzir broj stabala zaraženih PPV-D i PPV-Rec sojevima u neposrednoj okolini zasada, dobijeni rezultati pokazuju nešto efikasnije širenje PPV-Rec soja u odnosu na PPV-D soj, ali će se konačan sud o ovoj hipotezi doneti nakon još nekoliko godina ispitivanja.

Istraživanja su dopunjena i rezultatima o prisustvu vrsta i brojnosti lisnih vaši u zasadu šljive. Utvrđeno je da oko 50 različitih vrsta lisnih vaši posećuje zasad šljive, od kojih je značajan udeo vrsta koje su potvrđeni vektori PPV. Od vrsta 
koje su opisane kao vektori, u zasadu je potvrđeno prisustvo: Aphis craccivora Koch., A. spiraecola Pag., A. fabae Scop., A. gossypii Glover, Brachicaudus helicrysi Kalt., B. cardui L., Hyalopterus pruni Geofrr., Macrosiphum rosae L., Metopolophium dirhodum Walk., Myzus persicae Sulz., Phorodon humuli Schr. i Rhopalosiphum padi L.

Brojnost populacija lisnih vaši tokom ispitivanog perioda je značajno varirala. Termini najveće brojnosti su: maj-jun (u prolećnom periodu) i avgustseptembar ( $u$ jesenjem periodu). Sa stanovišta prakse, podaci o terminima najveće brojnosti populacija lisnih vaši su značajni radi planiranja optimalnih rokova primene pesticida. 


\section{LITERATURA}

Anonymous (2001): Certification scheme for almond, apricot, peach and plum. OEPP/EPPO Bulletin 31: 463-478.

Anonymous (2004): Plum pox potyvirus. Diagnostic protocols for regulated pests. OEPP/EPPO Bulletin 34: 247-256.

Adams M.J., Zerbini F.M., French R., Rabenstein F., Stenger D.C., Valkonen J.P.T. (2011): Potyviridae. In: King A.M.Q. Adams M.J., Carstens E.B., Lefkowitz E.J., (eds.). Virus Taxonomy: Classification and Nomenclature of Viruses. Ninth Repport of the International Committee on Taxonomy of Viruses. Elsevier/Academic Press, London, UK: 1069-1089.

Aleman-Verdaguer., Goudou-Urbino C., Dubern J., Beachy R.N., Fauquet C. (1997): Analysis of the sequence diversity of P1, HC, P3 NIb and CP genomic regions of several Yam mosaic potyvirus isolates: implications for the intraspecies molecular diversity of potyviruses. Journal of General Virology 78: 12531264.

Atanasoff D. (1932). Plum pox. A new virus disease. Yearbook University of Sofia, Faculty of Agriculture 11: 49-69.

Avinent L., Hermoso de Mendosa A., Llacer G. (1993): Comparison of sampling methods to evaluate aphid populations (Homoptera Aphidinae) alighting on apricot trees. Agronomie 13: 609-613.

Azzam O., Arboleda M., Umadhay K.M.L., de los Reyes J.B., Cruz F.S., Mackenzie A., McNally K.L. (2000): Genetic composition and complexity of virus populations at tungro-endemic and outbreak rice sites. Archives of Virology 145: 2643-2657. 
Bhardway S.V., Thakur P.D., Kohosla K., Sharma D.R. (1995): Detecton of Plum pox virus in India. Acta Horticulturae 386: 237-240.

Blanc S., Lopez-Moya J.J., Wang R., Garcia-Lampasona S., Thornbury D., Pirone T. (1997): A specific interaction between coat protein and helper component correlates with aphid transmission of a potyvirus. Virology 231: 141-147.

Blazek J., Paprstein F., Karesová R. (2003): Spread of Plum pox virus in new plum orchards of the Czech Republic and cultivar resistance. Acta Horticulturae 622: 359-364.

Blystad D.R., Haugslien S., Orstad K., Munthe T., Knudsen R., Hjeltnes S.H. (2007): An outbreak of Plum pox virus in Norway. Acta Horticulturae 734: 93-99.

Boscia D., Zeramdini H., Cambra M., Potere O., Gorris M.T., Myrta A., Di Terlizzi B., Savino V. (1997): Production and characterization of a monoclonal antibody specific to the M serotype of Plum pox potyvirus. European Journal of Plant Pathology 103: 477-480.

Bodin M., Glasa M., Verger D., Costes E., Dosba F. (2003): Distribution of the sour cherry isolate of Plum pox virus in infected Prunus rootstocks. Journal of Phytopathology 151: 625-630.

Boulila M., Briard P., Ravelonandro M. (2004): Plum pox virus in Tunsia: Sources and preliminary characteristics. Acta Horticulturae 657: 189-193.

Cambra M., Asensio M., Gorris M.T., Perez E., Camarasa E., Garcia J.A., Moya J.J., Lopez-Abela D., Vela C., Sanz A. (1994): Detection of Plum pox potyvirus using monoclonal antibodies to structural and non-structural proteins. OEPP/EPPO Bulletin 24: 585-595.

Cambra M., Gorris M.T., Marroquín C., Román M.P., Olmos A., Martínez M.C., Hermoso de Mendoza A., López A., Navarro L. (2000): Incidence and epidemiology of Citrus tristeza virus in the Valencian Community of Spain. Virus Research 71: 75-85.

Cambra M., Capote N., Myrta A., Llácer G. (2006): Plum pox virus and the estimated costs associated with sharka disease. OEPP/EPPO Bulletin 36: 202-204.

Candresse T., Macquaire G., Lanne M., Bousalem M., Quiot- Douine L., Quiot J.B., Dunez J. (1995): Analysis of Plum pox virus variability and development of strain-specific PCR assays. Acta Horticulturae 386, 357-369. 
Candresse T., Cambra M., Dallot S., Lanneau M., Asensio M., Gorris M.T., Revers F., Macquaire G., Olmos A., Boscia D., Quiot J.B., Dunez J. (1998): Comparison of monoclonal antibodies and polymerase chain reaction assays for the typing of isolates belonging to the $\mathrm{M}$ and $\mathrm{D}$ serotypes of Plum pox potyvirus. Phytopathology 88: 198-204.

Candresse T., Svanella-Dumas L., Gentit P., Caglayan K., Cevik B. (2007): First report of the presence of Plum pox virus Rec strain in Turkey. Plant Disease 91: 331

Cervera M.T., Riechmann J.L., Martin M.T., Garcia J.A. (1993): 3'-Terminal sequence of the Plum pox virus PS and ŏ6 isolates: evidence for RNA recombination within the Potyvirus group. Journal of General Virology 74. 329-334.

Clark M.F., Adams A.N. (1977): Characteristics of the microplate method of enzyme-linked immunosorbent assay for the detection of plant viruses. Journal of General Virology 34: 475-483.

Clement M., Posada D., Crandall K. (2000): TCS: a computer program to estimate gene genealogies. Molecular Ecology 9, 10: 1657-1660.

Crescenzi A., Nuzzaci M., Levy L., Piazzolla P., Hadidi A. (1995): Plum pox virus (PPV) in sweet cherry. Acta horticulturae 386: 219-225.

Crescenzi A., d'Aquino L., Comes S., Nuzzaci M., Oiazzola P. (1997): Characterization of the sweet cherry isolate of Plum pox virus. Plant Disease 81 (7): 711-714.

Dal Zotto A., Ortego J.M., Raigón J.M., Caloggero S., Rossini M., Ducasse D.A. (2006): First Report in Argentina of Plum pox virus causing Sharka disease in Prunus. Plant Disease 90: 523.

Dallot S., Labonne G., Boeglin M., Quiot-Douine L., Quiot J.B., Candresse, T. (1998): Peculiar Plum pox potyvirus D-populations are epidemic in peach trees. Acta Horticulturae 472: 355-366.

Dallot S., Gottwald T., Labonne G., Quiot J.B. (2004): Factors affecting the spread of Plum pox virus strain $\mathrm{M}$ in peach orchards subjected to roguing in France. Phytopathology 94: 1390-1398. 
Dallot S., Kamenova V., Glasa M., Pittnerova S., Kominek P., Paunović S., Jevremović D., Virscek-Marn M., Mavric Plesko I., Milusheva S. (2008): Prevalence and genetic structure of PPV-M in six European countries. Acta Horticulturae 781: 227-234.

Dallot S., Glasa M., Jevremovic D., Kamenova I., Paunovic S., Labonne G. (2011): Mediterranean and central-eastern European countries host viruses of two different clades of Plum pox virus strain M. Archives of virology 156, 3: 539542.

Damsteegt V., Waterworth H.E., Mink G.I., Howell W.E., Levy L. (1997): Prunus tomentosa as a diagnostic host for detection of Plum pox virus and other Prunus viruses. Plant Disease 81: 329-332.

Damsteegt V.D., Scorza R.A., Stone A.L., Schneider W.L., Webb K., Demuth M., Gildow F.E. (2007): Prunus host range of Plum pox virus (PPV) in the United States by aphid and graft inoculation. Plant Disease 91: 18-23.

Davis K., Rodoni B., Knox C., Sarec R., Moran J. (2002): Detection of Plum pox potyvirus in illegally imported plums intercepted at Sydney International Airport. Australasian Plant Pathology 31, 3: 313-314.

Deborre G., Maiss E., Jelkmann W. (1995): Biological and molecular investigations of several Plum pox virus (PPV) isolates. Acta Horticulturae 386: 253-262.

Desvignes J.C. (1999): Virus diseases of fruit trees. Centre Technique Interprofessoinenel des Fruits et Legumes, Paris, France.

Dicenta F., Pérez-Campoy P.J., Martínez-Gómez P., García-Brunton J., Botella M.A. (1999): Natural spread of sharka disease in orchards in Murcia (Spain). Acta Horticulturae 488: 775-778.

Dombrovsky A., Huet H., Chejanovsky N., Raccah B. (2005): Aphid transmission of a Potyvirus depends on suitability of the helper component and the $\mathrm{N}$ terminus of the coat protein. Archives of Virology 150: 287-298.

Drake J.W., Holland J.J. (1999): Mutation rates among RNA viruses. Proceedings of the National Academy of Science of the United States of America 96: 1391013913.

Dulić I., Šarić A. (1986): Outbreak of Plum pox virus on peaches in Yugoslavia. Acta Horticulturae 193: 161-165. 
Dulić-Marković I. (2003): Plum pox virus strains in Yugoslavia. In: Myrta A., Di Terlizzi B., Savino V. (eds.). Virus and Virus-Like Diseases of Stone Fruits, with Particular Reference to the Mediterranean Region. Option Méditerranéennes Sér. B/No. 45. Bari, Italy. Mediterranean Agronomic Institute: 61-63.

FAOSTAT (2011). http://faostat.fao.org/default.aspx.

Gentit P. (2006): Detection of Plum pox virus: biological methods. OEPP/EPPO Bulletin 36: 251-253.

Gianessi L.P., Silvers C.S., Sankula S., Carpenter J.E. (2002): Plant biotechnology: current and potential impact for improving pest management in U.S. agriculture. An analysis of 40 case studies. NCFAP, Washington, USA.

Gildow F., Damsteegt V., Stone A., Schneider W., Luster D., Levy L. (2004): Plum pox in North America: Identification of aphid vectors and potential role for fruit in virus spread. Phytopathology 94: 868-874.

Glasa M., Kúdela O., Marie-Jeanne V., Quiot J.B. (2001): Evidence of a naturally occurring recombinant isolate of Plum pox virus from Slovakia. Plant Disease 85: 920.

Glasa M., Marie-Jeanne V., Labonne G., Šubr Z., Kúdela O., Quiot J.B. (2002a): A natural population of recombinant Plum pox virus is viable and competitive under field conditions. European Journal of Plant Pathology 108: 843-853.

Glasa M., Marie-Jeanne V., Moury B., Kúdela O., Quiot J.B. (2002b): Molecular variability of the $\mathrm{P} 3-6 \mathrm{~K} 1$ genomic region among geographically and biologically distinct isolates of Plum pox virus. Archives of Virology 147: $563-575$.

Glasa M., Palkovics L., Komínek P., Labonne G., Pittnerová S., Kúdela O., Candresse T., Šubr Z. (2004): Geographically and temporally distant natural recombinant isolates of Plum pox virus are genetically very similar and form a unique PPV subgroup. Journal of General Virology 85: 2671-2681.

Glasa M., Candresse T. (2005): Plum pox virus. In: Jones A.T., Robinson D.J., Boonham N., Mumford R. (eds.). CMI/AAB Description of plant viruses no. 410. Association of Applied Biologists, Wellesbourne, UK. http://www.dpvweb.net/dpv/showdpv.php?dpvno=410. 
Glasa M., Paunović S., Jevremović D., Myrta A., Pittnerova S., Candresse T. (2005): Analysis of recombinant Plum pox virus (PPV) isolates from Serbia confirms genetic homogeneity and supports a regional origin for the PPV-Rec subgroup. Archives of Virology 150, 10: 2051-2060.

Glasa M., Svoboda J., Novakova S. (2007): Analysis of molecular and biological variability of Zuccini yellow mosaic virus isolates from Slovakia and Chech Republic. Virus Genes 35: 415-421.

Glasa M., Malinowski T., Predajňa L., Pupola N., Dekena D., Michalczuk L., Candresse T. (2011): Sequence variability, recombination analysis, and specific detection of the W strain of Plum pox virus. Phytopathology 101, 8: 980985.

Gottwald T.R., Avinent L., Llacer G., Hermoso de Mendosa A., Cambra M. (1995): Analysis of the spatial spread of sharka (Plum pox virus) in apricot and peach orchards in eastern Spain. Plant Disease 79: 266-278.

Hristov A. (1965): Reaction of thirty plum varieties infected by Plum pox virus. Horticultural and Viticultural Sciences II, 5: 573-580.

Isac M., Preda S., Marcu M. (1998): Aphid species - vectors of Plum pox virus. Acta Virologica 42: 233-234.

Isac M., Zagrai I. (2006): Plum pox virus (PPV) in Romania. EPPO/OEPP Bulletin 36: 213.

James D., Varga A. (2005): Nucleotide sequence analysis of Plum pox virus isolate W3174: Evidence of a new strain. Virus Research 110: 143-150.

Jaraush W. (2006): Plum pox virus (PPV) in Germany. OEPP/EPPO Bulletin 36: 209. Jevremović D., Dallot S., Paunović S. (2007): Typing, distribution and genetic structure of Plum pox virus in Serbia. European meeting on plum pox 2007, Pula, Croatia: 11.

Jevremović D. (2008): Molekularna karakterizacija i genetička struktura izolata virusa šarke šljive (Plum pox virus) u Srbiji. Magistarska teza. Poljoprivredni fakultet Univerziteta u Beogradu. Beograd-Zemun. 
Jevremović D., Paunović S., Dallot S. (2009): Assesment of the genetic structure of Plum pox virus (PPV) in Serbia. 21st International conference on virus and other graft transmissible diseases of fruit crops, July 5-10, Neustadt, Germany. Berichte aus dem Julius Kuhn-Institut 148: 73.

Jevremović D., Delić D., Lolić B., Paunović S. (2010): Assesment of the diversity of PPV-Rec strain in Bosnia and Herzegovina. SharCo Research Workshop, September 6-7, Sofia, Bulgaria. Book of abstracts: 24.

Jordović M. (1961): Nove indikator biljke pogodne za ispitivanje šarke šljive. Zaštita bilja 63-64: 100-103.

Jordović M., Janda LJ. (1963): Morfološko-anatomske i hemijske promene na plodovima nekih sorata šljiva zaraženih virusom šarke šljive. Zaštita bilja 76: 653-670.

Jordović M. (1965): The rate of spread šarka (plum pox) virus on some plum varieties in nature. Zaštita bilja 85-88: 353-355.

Jordović M. (1975): Study of sharka spread pattern in some plum orchards. Acta Horticulturae 44: 147-154.

Jordović M (1976): Situation of sharka disease on some experimental plum orchards after twenty years of the investigation. Acta Horticulturae 67: 159-163.

Josifović M. (1941): Bolesti voćaka. Srpska kraljevska akademija. Beograd.

Jridi C., Martin J.F., Marie-Jeanne V., Labonne G., Blanc S. (2006): Distinct viral populations differentiate and evolve independently in a single perennial host plant. Journal of Virology 80, 5: 2349-2357.

Kalashyan Y.A., Bilkey N.D., Verderevskaya T.D., Rubina E.V. (1994): Plum pox potyvirus on sour cherry in Moldova. OEPP/EPPO Bulletin 24: 645-650.

Kamenova I., Milusheva S. (2005): Sharka disease in Bulgaria: past, present and future. Biotechnology and Biotechnology Equipement, 19/special issue: 2240.

Kamenova I., Dallot S., Bozkova V., Milusheva S. (2011): First report of the Plum pox virus recombinant strain on peach in Bulgaria. Plant Disease 95, 10: 1320. 
Kegler H., Hartmann W. (1998): Present status of controlling conventional strains of Plum pox virus. In: Hadidi A., Khetarpal R.K., Koganezawa H. (eds.). Plant Virus Disease Control. APS Press, St Paul, USA: 616-628.

Kerlan C., Dunez J. (1979): Differenciation biologique et serologique de souches du virus de la sharka. Annales de Phytopathologie 11: 241-250.

Kimura M. (1980): A simple method for estimating evolutionary rate of base substitutions through comparative studies of nucleotide sequences. Journal of Molecular Evolution 16: 111-120.

Kollerova E., Novakova S., Šubr Z., Glasa M. (2006): Plum pox virus mixed infection detected on apricot in Pakistan. Plant Disease 90: 1108.

Kollerova E., Glasa M., Šubr Z.W. (2008): Western blotting analysis of the Plum pox virus capsid protein. Journal of Plant Pathology, 90, S1.19-22.

Kunze L., Krczal H. (1971): Transmission of sharka virus by aphids. Annales de Phytopathologie, hors serie: 255-260.

Hall T.A. (1999): BioEdit: a user-friendly biological sequence alignment editor and analysis program for Windows 95/98/NT. Nucleid Acids Symposium Series 41: 95-98.

Labone G., Yvon M., Quiot J.B., Avinert L., Llácer G. (1995): Aphids as a potential vectors of Plum pox virus: Comparison of methods of testing and epidemiological consequences. Acta Horticulturae 386: 207-217.

Labonne G., Dallot S. (2006): Epidemiology of sharka disease in France. OEPP/EPPO Bulletin 36: 267-270.

Levy L., Damsteegt V., Scorza R., Kölber M. (2000a): Plum pox potyvirus disease of stone fruits. APSnet Features. Online. doi: 10.1094/APSnetFeature-20000300.

Levy L., Damsteegt V., Welliver R. (2000b): First report of Plum pox virus (Sharka disease) in Prunus persica in the United States. Plant Disease 84: 202.

Llácer G., Avinent L., Hermoso de Mendoza A. (1992): Epidemiology of Plum pox (sharka) virus in Valencia (Spain). Acta Horticulturae 309: 129-134.

Llácer G. (2006): Hosts and symptoms of Plum pox virus: Herbaceous hosts. OEPP/EPPO Bulletin 36: 227-228. 
Lopez-Moya J.J., Wang R.Y., Pyrone T.P. (1999): Context of the coat protein DAG motif affects Potyvirus transmissibility by aphids. Journal of General Virology, 80: 3281-3288.

Maejima K., Hoshi H., Hashimoto M., Himeno M., Kawanishi T., Komatsu K., Yamaji Y., Hamamoto H., Namba S. (2010): First report of Plum pox virus infecting Japanese apricot (Prunus mume Sieb. Et Zucc.) in Japan. Journal of General Plant Pathology, 76: 229-231.

Malinowski T. (2006): Plum pox virus (PPV) in Poland. OEPP/EPPO Bulletin 36: 212.

Manachini B., Casati P., Aliverti I., Cinanni L. (2004): Transmission of PPV-M to Prunus persica by Brachycaudus schwartzi and Phorodon humuli (Hem., Aphididae). Journal of Applied Entomology 128: 677-680.

Marroquin C., Olmos A., Gorri M.T., Bertolini E., Martinez C., Carbonell E.A., Hermoso de Mendoza A., Cambra M. (2004): Estimation of the number of aphids carrying Citrus tristeza virus that visit adult citrus trees. Virus Research 100: 101-108.

Martínez-Gómez P., Dicenta F., Egea J. (2003): Effect of a traditional control method (tree removal) on the spread of sharka in an apricot orchard in Southeastern Spain. Phytopathologia Mediterranea 42: 161-166.

Matić S., Al-Rwahnih M., Myrta A. (2006): Diversity of Plum pox virus in Bosnia and Hercegovina. Plant Pathology 55: 11-17.

Mavrodieva V.A., Levy L. (2004): Real-time RT-PCR of PPV with R.A.P.I.D. a field field-hardened PCR unit for in-field detection. Acta Horticulturae 657: 141147.

Moya A., Garcia-Arenal F. (1995): Population genetics of viruses: an introduction. In: Gibbs A.J., Calisher C.H., Garcia-Arenal F. (eds) Molecular basis of evolution. Cambridge University Press, Cambridge, UK: 181-191.

Myrta A., Al Rwahnih M., Savino V. (2005): Presence of a recombinant isolate of Plum pox virus in Apulia. Journal of Plant Pathology 87, 2: 127-130.

Myrta A., Potere O., Boscia D., Candresse T., Cambra M., Savino V. (1998): Production of a monoclonal antibody specific to the El Amar strain of Plum pox virus. Acta Virologica 42, 4: 248-251. 
Myrta A., Potere O., Crescenzi A., Nuzzaci M., Boscia D. (2000): Properties of two monoclonal antibodies specific to the cherry strain of Plum pox virus. Journal of Plant Pathology 82: 95-101.

Myrta A., Boscia D., Potere O., Kolber M., Nemeth M., Di Terlizzi B., Cambra M., Savino V. (2001): Existence of two serological subclusters of Plum pox virus, strain M. European Journal of Plant Pathology 107: 845-848.

Myrta A., Varga A., James D. (2006): The complete genome sequence of an El Amar isolate of Plum pox virus (PPV) and its phylogenetic relationship to other PPV strains. Archives of Virology, 151: 1189-1198.

NCBI-National Center for Biotechnology Information. Bethesda MD, 20894 USA. http://www.ncbi.nlm.nih.gov/.

Navratil M., Safarova D., Karesova R., Petrzik K. (2005): First incidence of Plum pox virus on apricot trees in China. Plant Disease 89: 338.

Nei M., Kumar S. (2000): Molecular Evolution and Phylogenetics. Oxford University Press, New York, USA.

Nemchinov L., Hadidi A. (1996): Characterization of the sour cherry strain of Plum pox virus. Phytopathology 86: 575-580.

Nemchinov L., Hadidi A., Maiss E., Cambra M., Candresse T., Damsteegt V. (1996): Sour cherry ctrain of Plum Pox Potyvirus (PPV): Molecular and serological evidence for a new subgroup of PPV strains. Molecular Plant Pathology 86 (11): 1215-1221.

Nemchinov L., Kölber M., Nemeth M., Hadidi A. (1998): Molecular evidence of Plum pox virus-C subgroup in Hungary. Acta Horticulturae 472: 503-508.

Németh M. (1986): Virus, mycoplasma and rickettsia diseases of fruit trees. Academia Kiado, Budapest.

Olmos A., Dasi M.A., Candresse T., Cambra M. (1996): Print-capture PCR: a simple and high sensitive method for the detection of Plum pox virus (PPV) in plant tissues. Nucleic Acid Research 24, 11: 2192-2193.

Olmos A., Cambra M., Dasi M.A., Candresse T., Esteban O., Gorris M.T., Asensio M. (1997): Simultaneous detection and typing of Plum pox potyvirus (PPV) isolates by heminested-PCR and PCR-ELISA. Journal of Virological Methods 68: $127-137$. 
Olmos A., Cambra M., Esteban O., Gorris M.T., Terrada E. (1999): New device and method for capture, reverse-transcription and nested PCR in a single closed-tube. Nucleic Acid Research 27, 6: 1564-1565.

Olmos A., Bertolini E., Cambra M. (2002): Simultaneous and co-operational amplification (Co-PCR): A new concept for detection of plant viruses. Journal of Virological Methods 106: 51-59.

Olmos A., Bertolini E., Gil M., Cambra M. (2004): Real-time RT-PCR for quantitative detection of Plum pox virus. Acta Horticulturae 657: 149-153.

Palkovics L., Burgyán J., Ballázs E. (1993): Comparative sequence analysis of four complete primary structures of Plum pox virus. Virus Genes, 7: 339-347.

Pasquini G., Simeone A.M., Conte L., Barba M. (2000): RT-PCR evidence of the nontransmission through seed of Plum pox virus strains D and M. Journal of Plant Pathology, 82, 3: 221-226.

Paunović S., Jevremović D. (2002): Reakcija hibrida šljive 36/114/87 na različite sojeve virusa šarke. Zbornik rezimea XII Simpozijuma o zaštiti bilja i savetovanja o primeni pesticida, Zlatibor: 77.

Paunović S., Jevremović D. (2003): Detekcija i diferenciranje izolata virusa šarke. Zbornik naučnih radova XVIII savetovanja o unapređenju proizvodnje voća i grožđa Grocka, 9, 2: 67-74.

Paunović S., Jevremović D., Srećković M., Popović B. (2008): Praćenje brzine širenja virusa šarke u oglednom zasadu šljive Čačanska rodna. Zbornik rezimea IX Savetovanja o zaštiti bilja, Zlatibor: 132-133.

Paunović S., Jevremović D. (2009): Ispitivanje prisustva C-soja virusa šarke šljive u Srbiji. Zbornik rezimea VI Kongresa o zaštiti bilja sa Simpozijumom o biološkom suzbijanju invazivnih organizama, Zlatibor: 70.

Petrović-Obradović O. (2003): Biljne vaši (Homoptera:Aphididae) Srbije. Poljoprivredni Fakultet Univerziteta u Beogradu. Beograd.

Polak J. (2001): European spindle tree and common privet are new natural hosts of Plum pox virus. Acta Horticulturae 550: 125-128.

Polak J. (2002): Distribution of Plum pox virus in the Czech Republic. Plant Protection Science 38: 98-102. 
Polak J. (2006): Hosts and symptoms of Plum pox virus: woody species other than fruit and ornamental species of Prunus. EPPO Bulletin 36: 225-226.

Polak J., Kominek P. (2009): Distribution of Plum pox virus strains in natural sources in Czech Republic. Plant Protection Science 45: 144-147.

Predajňa L, Šubr Z, Candresse T, Glasa M. (2012): Evaluation of the genetic diversity of Plum pox virus in a single plum tree. Virus Research 167 (1): 112-117.

Pribek D., Palkovics L., Gaborjanyi R. (2001): Molecular characterization of Plum pox virus almond isolate. Acta Horticulturae 550, 1: 91-95.

Quiot J.B., Boeglin M., Adamolle C., Candresse T., Labonne G., Renauld L.Y. (1995): Behaviour of two isolates of Plum pox virus inoculated on peach and apricot trees: first results. Acta Horticulturae 386: 290-297.

Raccah B., Hueth H., Blanc S. (2001): Potyviruses. In: Haris K. F., Smith O.P., Duffus J.E. (eds.). Virus-insect-plant interactions, APS Press, St Paul, USA: 181-206.

Ranković M., Jordović M. (1970): Neka iskustva u izolaciji virusa šarke mehaničkim prenošenjem na zeljaste biljke. Zaštita bilja 108: 157-163.

Ranković M. (1974): Prečišćavanje virusa šarke i neke njegove osobine. Doktorska disertacija, Poljoprivredni fakultet Univerziteta u Beogradu, Zemun.

Ranković M. (1975): Pouzdanost nekih indikator biljaka za dokazivanje sojeva virusa šarke šljive. Zaštita bilja 26, 133: 275-284.

Ranković, M. (1980): Use of Prunus tomentosa for the detection and differentiation of Sharka and other viruses of plum. Acta Phytopatologica Academiae Scientiarium Hungaricae 15, 1-4: 303-308.

Ranković M., Paunović S., Dulić-Marković I. (1994): Current situation and future trends in solving Sharka problem in FR Yugoslavia. Acta Horticulturae 386: 241-247.

Ranković M., Paunović S., Dulić-Marković I. (1998): Deformacije grana i propadanje stabla šljive kao specifična reakcija na virus šarke. Zaštita bilja 49, 1, 224: 181-187.

Republički zavod za statistiku Republike Srbije. Beograd. http://webrzs.stat.gov.rs/WebSite/ 
Roy A.S., Smith I.M. (1994): Plum pox situation in Europe. OEPP/EPPO Bulletin 24: $515-523$.

Rwahnih M.Al, Myrta A., Terlizzi B.Di, Boscia D. (2000): First record of Plum pox virus in Jordan. Journal of Plant Pathology 82 (3): 243-244.

Salemi M., Vandamme A.M. (2004): The Phylogenetic Handbook. A practical approach to DNA and protein Phylogeny. Cambridge University Press, UK.

Salvador B., Garcia J.A., Simón-Mateo C. (2006): Casual agent of Sharka disease: Plum pox virus genome and function of gene products. EPPO/OEPP Bulletin, 36: 229-238.

Schade C. (1969): Characteristics and serology of sharka virus in plum. Zentralblatt Fuer Bakteriologie, Parasitenkunde, Infektionskrankheiten und Hygiene 123: 299-303.

Serçe C.U., Candresse T., Svanella-Dumas L., Krisbai L., Gazel M., Caglayan K. (2009): Further characterisation of a new recombinant group of Plum pox virus isolates, PPV-T, found in orchards in the Ankara province of Turkey. Virus Research 142: 121-126.

Shalaby A.A., Sahar Youssef A., Mazyad H. (2003): Occurence and molecular detection of Plum pox virus strains in Egypt. In: Myrta A., Di Terlizzi B., Savino V. (eds.). Virus and Virus-Like Diseases of Stone Fruits, with Particular Reference to the Mediterranean Region. Option Méditerranéennes Sér. B/No. 45. Bari, Italy. Mediterranean Agronomic Institute: 89-93.

SharCo PPV database: http://w3.pierroton.inra.fr:8060/users/login.

Schneider W.L., Sherman D.J., Stone A.L., Damsteegt V.D., Frederick R.D. (2004): Specific detection and quantification of Plum pox virus by real-time fluorescent reverse transcription-PCR. Journal of Virological Methods 120, 1: 97-105.

Scholthof K.G., Adkins S., Czosnek H., Palukaitis P., Jacquiot E., Hohn T., Hohn B., Saunders K., Candresse T., Ahlquist P., Hemenway C., Foster G.D. (2011): Top 10 plant viruses in molecular plant pathology. Molecular Plant Pathology 12, 9: 938-954. 
Spiegel S., Kovalenko E.M., Varga A., James D. (2004): Detection and partial molecular characterization of two Plum pox virus isolates from plum and wild apricot in southeast Kazakhstan. Plant Disease 88: 973-979.

Stobbs L.W., Van Driel L., Whybourne K., Carlson C. (2005): Distribution of Plum pox virus in residential sites, commercial nurseries and native plant species in the Niagara Region, Ontario, Canada. Plant Disease 89, 8: 822-827.

Szemes M., Kalman M., Myrta A., Boscia D., Nemeth M., Kölber M., Dorgai L. (2001): Integrated RT-PCR/nested PCR diagnosis for differentiating between subgroups of Plum pox virus. Journal of Virological Methods 92: 165-175.

Szathmáry E., Palkovics L. (2010): Natural deletion is not unique in the coat protein (CP) of recombinant Plum pox virus (PPV) isolates in Hungary. Julius-Kuhn-Archiv 427: 151-155.

Šubr Z., Pittnerova S., Glasa M. (2004): A simplified RT-PCR-based detection of recombinant Plum pox virus isolates. Acta virologica 48: 173-176.

Šutić D., Jordović M., Ranković M., Festić H. (1971): Comparative studies of some sharka (plum pox) virus isolates. Annales de Phytopathologie (hors. ser): 185-192.

Šutić D. (1995): Viroze biljaka. Institut za zaštitu bilja i životnu sredinu, Beograd.

Tamura K., Peterson D., Peterson N., Stecher G., Nei M., Kumar S. (2011): MEGA5: Molecular evolutionary genetics analysis using maximum likelihood, evolutionary distance, and maximum parsimony methods. Molecular Biology and Evolution 28: 2731-2739.

Templeton A.R., Crandall K.A., Sing C.F. (1992): A cladistic analysis of phenotypic associations with haplotypes inferred from restriction endonuclease mapping and DNA sequence data. III. Cladogram estimation. Genetics 132: $619-633$.

Thompson J.D., Higgins D.G., Gibson T.J. (1994): CLUSTAL W: improving the sensitivity of progressive multiple sequence alignment through sequence weighting, position-specific gap penalties and weight matrix choice. Nucleic Acids Research 22: 4673-4680. 
Thompson D., McCann M., MacLeod M., Lye D., Green M., James D. (2001): First report of Plum pox virus in Ontario, Canada. Plant Disease 85: 97.

Thompson, D. (2009): First Report of Plum pox virus Recombinant Strain on Prunus spp. in Canada. Plant Disease 93: 674

Topchiiska, M. (1994): Plum pox virus in sweet and sour cherry in Bulgaria. Доклада на Българската академия на науките, 47 (1): 85-87.

Urcuqui-Inchima S., Haenni A., Bernardi F. (2001): Potyvirus proteins: a wealth of functions. Virus Research 74: 157-175.

Varga A., James D. (2005): Detection and differentiation of Plum pox virus using real-time Multiplex PCR with SYBR Green and melting curve analysis: a rapid method for strain typing. Journal of Virological Methods 123: 213220.

Varveri C., Dimou D., Di Terlizzi B. (1999): Preliminary data of monitoring of natural spread of sharka in commercial orchards in Greece. Acta Horticulturae 488: 793-796.

Viršček Marn M., Mavrič Pleško I., Zindović J. (2008): The discovery and characterization of Plum pox virus (PPV) isolates in Montenegro. Plant Pathology 57: 393.

Virscek Marn M., Mavric Plesko I., Zindovic J., Miladinovic Z. (2012): Diversity of Plum pox virus isolates in Montenegro. Journal of Plant Pathology 94, 1: 201-204.

Wei T., Yang J., Liao F., Gao F., Lu L., Zhang X., Li F., Wu Z., Lin Q., Xie L., Lin H. (2009): Genetic diversity and population structure of Rice stripe virus in China. Journal of General Virology 90: 1025-1034.

Wetzel T., Candresse T., Ravelonandro M., Delbos R.P., Mazyad H., Aboul-Ata A.E., Dunez J. (1991a): Nucleotide sequence of the 3'-terminal region of the RNA of the El Amar strain of Plum pox potyvirus. Journal of General Virology 72: 1741-1746.

Wetzel T., Candresse T., Ravelonandro M., Dunez J. (1991b): A polymerase chain reaction assay adapted to Plum pox potyvirus detection. Journal of Virological Methods 33: 355-365. 
Wetzel T., Candresse T., Macquaire G., Ravelonandro M., Dunez J. (1992): A highly sensitive immunocapture polymerase chain reaction method for Plum pox potyvirus detection. Journal of Virological Methods 39: 27-37.

Zagrai L., Zagrai I. (2008): Non-transmission of Plum pox virus D and Rec strains through seeds in plum. Bulletin UASVM, Horticulture 65: 523.

Zagrai I., Zagrai L., Kelemen B., Petricele I., Pamfil D., Popescu O., Preda S., Briciu A. (2010): Typing and distribution of Plum pox virus isolates in Romania. Julius-Kuhn-Archiv 427: 342-346.

Zamharir M.G., Bashir N.S., Khakvar R. (2006): Plum pox virus (PPV) in Iran. OEPP/EPPO Bulletin 36: 210.

Zawadska B. (1982): The virus isolated from declining plum trees primarily inoculated with Plum pox virus. Acta Horticulturae 130: 73-79. 


\begin{tabular}{|c|c|c|c|c|c|c|c|c|c|c|c|c|c|}
\hline \multirow[b]{3}{*}{$\begin{array}{c}\text { REDNI } \\
\text { BROJ }\end{array}$} & \multirow[b]{3}{*}{ OKRUG } & \multirow[b]{3}{*}{ LOKALITET } & \multirow[b]{3}{*}{$\begin{array}{c}\text { BROJ } \\
\text { ZASADA }\end{array}$} & \multirow[b]{3}{*}{ DOMAĆIN } & \multirow[b]{3}{*}{ SORTA } & \multirow[b]{3}{*}{ TIP ZASADA } & \multicolumn{7}{|c|}{ REZULTATI PCR ANALIZA } \\
\hline & & & & & & & \multirow[b]{2}{*}{$\begin{array}{c}\text { STAROST } \\
\text { ZASADA } \\
\text { (god.) }\end{array}$} & \multicolumn{3}{|c|}{ N-ter CP } & \multicolumn{2}{|c|}{ CI } & \multirow[b]{2}{*}{ SOJ ${ }^{c}$} \\
\hline & & & & & & & & $\begin{array}{l}\text { PROCENJENI } \\
\text { \% ZARAZE U } \\
\text { ZASADU }\end{array}$ & $\begin{array}{c}\text { P3M } \\
\text {-P4 }\end{array}$ & $\begin{array}{l}\text { P3D- } \\
\text { P4 }\end{array}$ & $\begin{array}{c}\text { CIP } \\
\text { M }\end{array}$ & $\begin{array}{c}\text { CIP } \\
\text { D }\end{array}$ & \\
\hline 1 & Moravički & Ivanjica & 1 & P. domestica & Stenley & intenzivan & 5 & 40 & $+\mathrm{a}$ & $-\mathrm{b}$ & - & + & Rec \\
\hline 2 & Moravički & Ivanjica & & P. domestica & Stenley & & & & + & - & - & + & Rec \\
\hline 3 & Moravički & Ivanjica & & P. domestica & Stenley & & & & + & - & - & + & Rec \\
\hline 4 & Moravički & Ivanjica & 2 & P. domestica & Crvena ranka & poluintenzivan & 18 & 10 & - & + & - & + & D \\
\hline 5 & Moravički & Ivanjica & & P. domestica & Crvena ranka & & & & - & + & - & + & D \\
\hline 6 & Moravički & Ivanjica & & P. domestica & Crvena ranka & & & & - & + & - & + & D \\
\hline 7 & Moravički & Ivanjica & 3 & P. domestica & Čačanska rodna & intenzivan & 6 & 90 & + & - & - & + & Rec \\
\hline 8 & Moravički & Ivanjica & & P. domestica & Čačanska rodna & & & & + & - & - & + & Rec \\
\hline 9 & Moravički & Ivanjica & & P. domestica & Stenley & & & & + & - & - & + & Rec \\
\hline 10 & Moravički & Ivanjica & 4 & P. domestica & Čačanska rodna & intenzivan & 6 & 90 & + & - & - & + & Rec \\
\hline 11 & Moravički & Ivanjica & & P. domestica & Čačanska rodna & & & & + & - & - & + & $\operatorname{Rec}$ \\
\hline 12 & Moravički & Ivanjica & & P. domestica & Stenley & & & & + & - & + & + & $M+\operatorname{Rec}$ \\
\hline 13 & Zlatiborski & Arilje & 5 & P. domestica & Stenley & intenzivan & 17 & 90 & + & - & + & - & M \\
\hline 14 & Zlatiborski & Arilje & & P. domestica & Čačanska rodna & & & & + & - & - & + & Rec \\
\hline 15 & Zlatiborski & Arilje & & P. domestica & Stenley & & & & + & - & - & + & Rec \\
\hline 16 & Zlatiborski & Arilje & 6 & P. domestica & Stenley & poluintenzivan & 15 & 90 & + & - & + & + & M+Rec \\
\hline 17 & Zlatiborski & Arilje & & P. domestica & Stenley & & & & + & - & - & + & Rec \\
\hline 18 & Zlatiborski & Arilje & & P. domestica & Čačanska rodna & & & & + & - & - & + & Rec \\
\hline 19 & Zlatiborski & Arilje & 7 & P. domestica & Čačanska rodna & intenzivan & 13 & 100 & + & - & + & - & M \\
\hline 20 & Zlatiborski & Arilje & & P. domestica & Stenley & & & & + & + & + & + & $\mathrm{M}+\mathrm{D}+\mathrm{Rec}$ \\
\hline 21 & Zlatiborski & Arilje & & P. domestica & Bluefree & & & & + & + & - & + & D+Rec \\
\hline 22 & Zlatiborski & Požega & 8 & P. domestica & Čačanska lepotica & intenzivan & 6 & 20 & + & + & - & + & $\mathrm{D}+\mathrm{Rec}$ \\
\hline 23 & Zlatiborski & Požega & & P. domestica & Čačanska rodna & & & & + & - & - & + & Rec \\
\hline 24 & Zlatiborski & Požega & & P. domestica & Čačanska rodna & & & & + & - & - & + & Rec \\
\hline 25 & Zlatiborski & Požega & 9 & P. domestica & Čačanska lepotica & intenzivan & 5 & 40 & + & - & - & + & Rec \\
\hline 26 & Zlatiborski & Požega & & P. domestica & Čačanska lepotica & & & & + & - & - & + & Rec \\
\hline 27 & Zlatiborski & Požega & & P. domestica & Čačanska rodna & & & & + & - & - & + & Rec \\
\hline 28 & Šumadijski & Kragujevac & 10 & P. domestica & Stenley & poluintenzivan & 12 & 90 & + & - & - & + & Rec \\
\hline
\end{tabular}

LEGENDA:

a pozitivna reakcija

- negativna reakcija

c M - PPV-M soj; D - PPV-D soj; Rec - PPV-Rec soj; NEG - nije detektovan virus šarke 


\begin{tabular}{|c|c|c|c|c|c|c|c|c|c|c|c|c|c|}
\hline \multirow[b]{3}{*}{$\begin{array}{c}\text { REDNI } \\
\text { BROJ }\end{array}$} & \multirow[b]{3}{*}{ OKRUG } & \multirow[b]{3}{*}{ LOKALITET } & \multirow[b]{3}{*}{$\begin{array}{c}\text { BROJ } \\
\text { ZASADA }\end{array}$} & \multirow[b]{3}{*}{ DOMAĆIN } & \multirow[b]{3}{*}{ SORTA } & \multirow[b]{3}{*}{ TIP ZASADA } & \multicolumn{7}{|c|}{ REZULTATI PCR ANALIZA } \\
\hline & & & & & & & \multirow[b]{2}{*}{$\begin{array}{c}\text { STAROST } \\
\text { ZASADA } \\
\text { (god.) }\end{array}$} & \multicolumn{3}{|c|}{ N-ter CP } & \multicolumn{2}{|c|}{ CI } & \multirow[b]{2}{*}{ soJ } \\
\hline & & & & & & & & $\begin{array}{c}\text { PROCENJENI } \\
\text { \% ZARAZE U } \\
\text { ZASADU }\end{array}$ & $\begin{array}{l}\text { P3M } \\
\text {-P4 }\end{array}$ & $\begin{array}{l}\text { P3D- } \\
\text { P4 }\end{array}$ & $\begin{array}{c}\text { CIP } \\
\text { M }\end{array}$ & $\begin{array}{c}\text { CIP } \\
\text { D }\end{array}$ & \\
\hline 29 & Šumadijski & Kragujevac & & P. domestica & Čačanska rodna & & & & + & - & - & + & $\operatorname{Rec}$ \\
\hline 30 & Šumadijski & Kragujevac & & P. domestica & Stenley & & & & + & + & + & + & $M+D$ \\
\hline 31 & Šumadijski & Kragujevac & 11 & P. domestica & Čačanska rodna & intenzivan & 6 & 80 & - & + & - & + & D \\
\hline 32 & Šumadijski & Kragujevac & & P. domestica & Čačanska rodna & & & & + & - & - & + & $\operatorname{Rec}$ \\
\hline 33 & Šumadijski & Kragujevac & & P. domestica & Čačanska rodna & & & & + & - & - & + & Rec \\
\hline 34 & Šumadijski & Kragujevac & 12 & P. armeniaca & Hungarian best & intenzivan & 5 & 5 & + & - & - & + & Rec \\
\hline 35 & Šumadijski & Kragujevac & & P. armeniaca & Hungarian best & & & & + & - & - & + & Rec \\
\hline 36 & Šumadijski & Kragujevac & & P. domestica & Čačanska rodna & & & & - & + & - & + & D \\
\hline 37 & Šumadijski & Topola & 13 & P. domestica & Čačanska lepotica & intenzivan & 5 & 50 & + & - & - & + & $\operatorname{Rec}$ \\
\hline 38 & Šumadijski & Topola & & P. domestica & Čačanska lepotica & & & & - & + & - & + & D \\
\hline 39 & Šumadijski & Topola & & P. domestica & Čačanska rodna & & & & + & - & - & + & Rec \\
\hline 40 & Kolubarski & Ljig & 14 & P. domestica & Čačanska rodna & intenzivan & 7 & 5 & + & - & - & + & Rec \\
\hline 41 & Kolubarski & Ljig & & P. domestica & Čačanska lepotica & & & & + & - & - & + & Rec \\
\hline 42 & Kolubarski & Ljig & & P. domestica & Čačanska lepotica & & & & + & - & - & + & Rec \\
\hline 43 & Kolubarski & Ljig & 15 & P. domestica & Požegača & ekstenzivan & 20 & 90 & + & - & - & + & Rec \\
\hline 44 & Kolubarski & Ljig & & P. domestica & Stenley & & & & + & - & - & + & Rec \\
\hline 45 & Kolubarski & Ljig & & P. domestica & Požegača & & & & + & - & - & + & Rec \\
\hline 46 & Kolubarski & Ljig & 16 & P. domestica & Crvena ranka & intenzivan & 15 & 90 & + & - & + & - & M \\
\hline 47 & Kolubarski & Ljig & & P. domestica & Čačanska rodna & & & & + & - & + & + & $M+\operatorname{Rec}$ \\
\hline 48 & Kolubarski & Ljig & & P. domestica & Čačanska rodna & & & & - & + & - & + & D \\
\hline 49 & Kolubarski & Mionica & 17 & P. domestica & Požegača & ekstenzivan & 30 & 80 & + & - & - & + & Rec \\
\hline 50 & Kolubarski & Mionica & & P. domestica & Požegača & & & & + & - & - & + & $\operatorname{Rec}$ \\
\hline 51 & Kolubarski & Mionica & & P. domestica & Požegača & & & & + & - & - & + & Rec \\
\hline 52 & Kolubarski & Mionica & 18 & P. domestica & Čačanska rodna & intenzivan & 6 & 40 & + & - & - & + & Rec \\
\hline 53 & Kolubarski & Mionica & & P. domestica & Čačanska rodna & & & & + & - & - & + & Rec \\
\hline 54 & Kolubarski & Mionica & & P. domestica & Čačanska rodna & & & & + & - & - & + & Rec \\
\hline 55 & Kolubarski & Ljig & 19 & P. domestica & Požegača & napušten & 35 & 50 & + & - & - & + & Rec \\
\hline 56 & Kolubarski & Ljig & & P. domestica & Požegača & & & & + & - & - & + & Rec \\
\hline
\end{tabular}

LEGENDA:

+ pozitivna reakcija

- negativna reakcija

c M - PPV-M soj; D - PPV-D soj; Rec - PPV-Rec soj; NEG - nije detektovan virus šarke 


\begin{tabular}{|c|c|c|c|c|c|c|c|c|c|c|c|c|c|}
\hline \multirow[b]{3}{*}{$\begin{array}{c}\text { REDNI } \\
\text { BROJ }\end{array}$} & \multirow[b]{3}{*}{ OKRUG } & \multirow[b]{3}{*}{ LOKALITET } & \multirow[b]{3}{*}{$\begin{array}{c}\text { BROJ } \\
\text { ZASADA }\end{array}$} & \multirow[b]{3}{*}{ DOMAĆIN } & \multirow[b]{3}{*}{ SORTA } & \multirow[b]{3}{*}{ TIP ZASADA } & \multicolumn{7}{|c|}{ REZULTATI PCR ANALIZA } \\
\hline & & & & & & & \multirow[b]{2}{*}{$\begin{array}{c}\text { STAROST } \\
\text { ZASADA } \\
\text { (god.) }\end{array}$} & \multicolumn{3}{|c|}{ N-ter CP } & \multicolumn{2}{|c|}{ CI } & \multirow[b]{2}{*}{ SoJ } \\
\hline & & & & & & & & $\begin{array}{c}\text { PROCENJENI } \\
\text { \% ZARAZE U } \\
\text { ZASADU } \\
\end{array}$ & $\begin{array}{l}\text { P3M } \\
\text {-P4 }\end{array}$ & $\begin{array}{l}\text { P3D- } \\
\text { P4 }\end{array}$ & $\begin{array}{c}\text { CIP } \\
\text { M }\end{array}$ & $\begin{array}{c}\text { CIP } \\
\text { D }\end{array}$ & \\
\hline 57 & Kolubarski & Ljig & & P. domestica & Požegača & & & & + & - & - & + & $\operatorname{Rec}$ \\
\hline 58 & Kolubarski & Lajkovac & 20 & P. domestica & Čačanska rodna & intenzivan & 6 & 80 & + & - & - & + & $\operatorname{Rec}$ \\
\hline 59 & Kolubarski & Lajkovac & & P. domestica & Čačanska rodna & & & & + & + & - & + & $D+\operatorname{Rec}$ \\
\hline 60 & Kolubarski & Lajkovac & & P. domestica & Čačanska rodna & & & & + & - & - & + & $\operatorname{Rec}$ \\
\hline 61 & Kolubarski & Lajkovac & 21 & P. domestica & Požegača & ekstenzivan & 20 & 60 & - & + & - & + & D \\
\hline 62 & Kolubarski & Lajkovac & & P. domestica & Požegača & & & & + & - & - & + & Rec \\
\hline 63 & Kolubarski & Lajkovac & & P. domestica & Požegača & & & & + & + & - & + & $D+\operatorname{Rec}$ \\
\hline 64 & Kolubarski & $\mathrm{Ub}$ & 22 & P. armeniaca & / & intenzivan & 5 & 20 & + & - & - & + & $\operatorname{Rec}$ \\
\hline 65 & Kolubarski & $\mathrm{Ub}$ & & P. domestica & Stenley & & & & - & + & - & + & D \\
\hline 66 & Kolubarski & $\mathrm{Ub}$ & & P. domestica & Stenley & & & & + & + & - & + & D+Rec \\
\hline 67 & Kolubarski & $\mathrm{Ub}$ & 23 & P. domestica & Stenley & intenzivan & 10 & 60 & + & + & - & + & $\mathrm{D}+\operatorname{Rec}$ \\
\hline 68 & Kolubarski & $\mathrm{Ub}$ & & P. domestica & Valjevka & & & & + & - & - & + & $\operatorname{Rec}$ \\
\hline 69 & Kolubarski & $\mathrm{Ub}$ & 24 & P. domestica & Stenley & intenzivan & 10 & 90 & + & - & + & - & $\mathbf{M}$ \\
\hline 70 & Kolubarski & $\mathrm{Ub}$ & & P. domestica & Čačanska rodna & & & & + & - & + & + & M+Rec \\
\hline 71 & Kolubarski & $\mathrm{Ub}$ & & P. domestica & Čačanska rodna & & & & + & - & - & + & $\operatorname{Rec}$ \\
\hline 72 & Moravički & $\begin{array}{c}\text { Gornji } \\
\text { Milanovac }\end{array}$ & 25 & P. domestica & Stenley & intenzivan & 10 & 80 & - & + & - & + & D \\
\hline 73 & Moravički & $\begin{array}{c}\text { Gornji } \\
\text { Milanovac }\end{array}$ & & P. domestica & Stenley & & & & + & - & - & + & $\operatorname{Rec}$ \\
\hline 74 & Moravički & $\begin{array}{c}\text { Gornji } \\
\text { Milanovac }\end{array}$ & & P. domestica & Stenley & & & & + & - & - & + & Rec \\
\hline 75 & Mačvanski & Koceljeva & 26 & P. domestica & Stenley & poluintenzivan & 15 & 50 & + & - & - & + & $\operatorname{Rec}$ \\
\hline 76 & Mačvanski & Koceljeva & & P. domestica & Stenley & & & & + & - & - & + & Rec \\
\hline 77 & Mačvanski & Koceljeva & & P. domestica & Stenley & & & & + & - & - & + & Rec \\
\hline 78 & Kolubarski & Osečina & 27 & P. domestica & Stenley & intenzivan & 10 & 20 & - & + & - & + & D \\
\hline 79 & Kolubarski & Osečina & & P. domestica & Stenley & & & & - & + & - & + & D \\
\hline 80 & Kolubarski & Osečina & & P. domestica & Stenley & & & & + & - & - & + & Rec \\
\hline 81 & Kolubarski & Osečina & 28 & P. domestica & Čačanska rodna & poluintenzivan & 7 & 70 & + & + & + & + & $M+D$ \\
\hline 82 & Kolubarski & Osečina & & P. domestica & Čačanska rodna & & & & + & + & - & + & D+Rec \\
\hline 83 & Kolubarski & Osečina & & P. domestica & Čačanska rodna & & & & + & - & - & + & $\operatorname{Rec}$ \\
\hline
\end{tabular}




\begin{tabular}{|c|c|c|c|c|c|c|c|c|c|c|c|c|c|}
\hline \multirow[b]{3}{*}{$\begin{array}{c}\text { REDNI } \\
\text { BROJ }\end{array}$} & \multirow[b]{3}{*}{ OKRUG } & \multirow[b]{3}{*}{ LOKALITET } & \multirow[b]{3}{*}{$\begin{array}{c}\text { BROJ } \\
\text { ZASADA } \\
\end{array}$} & \multirow[b]{3}{*}{ DOMAĆIN } & \multirow[b]{3}{*}{ SORTA } & \multirow[b]{3}{*}{ TIP ZASADA } & \multirow[b]{3}{*}{$\begin{array}{c}\text { STAROST } \\
\text { ZASADA } \\
\text { (god.) }\end{array}$} & \multicolumn{6}{|c|}{ REZULTATI PCR ANALIZA } \\
\hline & & & & & & & & \multicolumn{3}{|c|}{ N-ter CP } & \multicolumn{2}{|c|}{ CI } & \multirow[b]{2}{*}{ SoJ } \\
\hline & & & & & & & & $\begin{array}{c}\text { PROCENJENI } \\
\text { \% ZARAZE U } \\
\text { ZASADU }\end{array}$ & $\begin{array}{c}\text { P3M } \\
- \text { P4 }\end{array}$ & $\begin{array}{c}\text { P3D- } \\
\text { P4 }\end{array}$ & $\begin{array}{c}\text { CIP } \\
\text { M }\end{array}$ & $\begin{array}{c}\text { CIP } \\
\text { D }\end{array}$ & \\
\hline 84 & Kolubarski & Osečina & 29 & P. domestica & Požegača & ekstenzivan & 10 & 25 & + & - & - & + & Rec \\
\hline 85 & Kolubarski & Osečina & & P. domestica & Požegača & & & & - & + & - & + & D \\
\hline 86 & Kolubarski & Valjevo & 30 & P. domestica & Požegača & poluintenzivan & 5 & 30 & + & + & - & + & D+Rec \\
\hline 87 & Kolubarski & Valjevo & & P. domestica & Čačanska rodna & & & & + & - & - & + & Rec \\
\hline 88 & Kolubarski & Valjevo & & P. domestica & Požegača & & & & + & + & - & + & D+Rec \\
\hline 89 & Moravički & Čačak & 31 & P. armeniaca & / & poluintenzivan & 18 & 60 & + & - & - & + & $\operatorname{Rec}$ \\
\hline 90 & Moravički & Čačak & & P. armeniaca & I & & & & + & - & - & + & Rec \\
\hline 91 & Moravički & Čačak & & P. armeniaca & l & & & & + & - & - & + & Rec \\
\hline 92 & Moravički & Čačak & 32 & P. domestica & Stenley & poluintenzivan & 10 & 40 & + & - & - & + & Rec \\
\hline 93 & Moravički & Čačak & & P. domestica & Čačanska najbolja & & & & - & + & - & + & D \\
\hline 94 & Moravički & Čačak & & P. domestica & Stenley & & & & + & + & - & + & $\mathrm{D}+\operatorname{Rec}$ \\
\hline 95 & Zaječarski & Zaječar & 33 & P. domestica & Čačanska rana & intenzivan & 2 & 5 & + & + & - & + & D+Rec \\
\hline 96 & Zaječarski & Zaječar & & P. domestica & Čačanska rana & & & & + & + & - & + & $D+\operatorname{Rec}$ \\
\hline 97 & Zaječarski & Zaječar & & P. domestica & Čačanska rana & & & & + & + & - & + & D+Rec \\
\hline 98 & Zaječarski & Zaječar & 34 & P. domestica & Stenley & poluintenzivan & 10 & 100 & - & + & - & + & D \\
\hline 99 & Zaječarski & Zaječar & & P. domestica & Stenley & & & & - & + & - & + & D \\
\hline 100 & Zaječarski & Zaječar & & P. domestica & Stenley & & & & + & + & - & + & D+Rec \\
\hline 101 & Zaječarski & Zaječar & 35 & P. domestica & Požegača & poluintenzivan & 15 & 50 & - & + & - & + & D \\
\hline 102 & Zaječarski & Zaječar & & P. domestica & Stenley & & & & - & + & - & + & D \\
\hline 103 & Zaječarski & Zaječar & & P. domestica & Stenley & & & & - & + & - & + & D \\
\hline 104 & Zaječarski & Zaječar & 36 & P. domestica & Stenley & poluintenzivan & 12 & 90 & - & + & - & + & D \\
\hline 105 & Zaječarski & Zaječar & & P. domestica & Stenley & & & & - & + & - & + & D \\
\hline 106 & Zaječarski & Zaječar & & P. domestica & Stenley & & & & - & + & - & + & D \\
\hline 107 & Zaječarski & Zaječar & 37 & P. domestica & / & napušten & 27 & 70 & + & - & + & - & $\mathbf{M}$ \\
\hline 108 & Zaječarski & Zaječar & & P. domestica & / & & & & + & - & + & - & M \\
\hline 109 & Zaječarski & Zaječar & & P. domestica & / & & & & + & - & + & - & $\mathbf{M}$ \\
\hline 110 & Zaječarski & Zaječar & & P. domestica & I & & & & + & + & + & + & $M+D$ \\
\hline 111 & Zaječarski & Zaječar & 38 & P. domestica & Stenley & napušten & 27 & 100 & + & - & + & - & $\mathbf{M}$ \\
\hline
\end{tabular}

LEGENDA:

+ pozitivna reakcija

- negativna reakcija

c M - PPV-M soj; D - PPV-D soj; Rec - PPV-Rec soj; NEG - nije detektovan virus šarke 


\begin{tabular}{|c|c|c|c|c|c|c|c|c|c|c|c|c|c|}
\hline \multirow[b]{3}{*}{$\begin{array}{c}\text { REDNI } \\
\text { BROJ }\end{array}$} & \multirow[b]{3}{*}{ OKRUG } & \multirow[b]{3}{*}{ LOKALITET } & \multirow[b]{3}{*}{$\begin{array}{c}\text { BROJ } \\
\text { ZASADA }\end{array}$} & \multirow[b]{3}{*}{ DOMAĆIN } & \multirow[b]{3}{*}{ SORTA } & \multirow[b]{3}{*}{ TIP ZASADA } & \multicolumn{7}{|c|}{ REZULTATI PCR ANALIZA } \\
\hline & & & & & & & \multirow[b]{2}{*}{$\begin{array}{c}\text { STAROST } \\
\text { ZASADA } \\
\text { (god.) }\end{array}$} & \multirow[b]{2}{*}{$\begin{array}{l}\text { PROCENJENI } \\
\text { \% ZARAZE U } \\
\text { ZASADU }\end{array}$} & \multicolumn{2}{|c|}{ N-ter CP } & \multicolumn{2}{|c|}{ CI } & \multirow[b]{2}{*}{ SoJ } \\
\hline & & & & & & & & & $\begin{array}{c}\text { P3M } \\
\text {-P4 }\end{array}$ & $\begin{array}{c}\text { P3D- } \\
\text { P4 }\end{array}$ & $\begin{array}{c}\text { CIP } \\
\mathbf{M}\end{array}$ & $\begin{array}{c}\text { CIP } \\
\text { D }\end{array}$ & \\
\hline 112 & Zaječarski & Zaječar & & P. domestica & Stenley & & & & + & - & + & - & $\mathbf{M}$ \\
\hline 113 & Zaječarski & Zaječar & & P. domestica & Stenley & & & & + & - & + & - & M \\
\hline 114 & Zaječarski & Zaječar & 39 & P. domestica & Čačanska najbolja & ekstenzivan & 15 & 50 & - & + & - & + & D \\
\hline 115 & Zaječarski & Zaječar & & P. domestica & Čačanska najbolja & & & & - & + & - & + & D \\
\hline 116 & Zaječarski & Zaječar & & P. domestica & Stenley & & & & - & + & - & + & D \\
\hline 117 & Zaječarski & Knjaževac & 40 & P. domestica & Stenley & intenzivan & 15 & 50 & + & - & + & - & M \\
\hline 118 & Zaječarski & Knjaževac & & P. domestica & Stenley & & & & - & + & - & + & D \\
\hline 119 & Zaječarski & Knjaževac & & P. domestica & Stenley & & & & - & + & - & + & D \\
\hline 120 & Šumadijski & Knić & 41 & P. domestica & Čačanska lepotica & intenzivan & 5 & 15 & + & - & - & + & Rec \\
\hline 121 & Šumadijski & Knić & & P. domestica & Čačanska lepotica & & & & + & - & - & + & Rec \\
\hline 122 & Šumadijski & Knić & & P. domestica & Čačanska lepotica & & & & - & + & - & + & D \\
\hline 123 & Zlatiborski & Požega & 42 & P. domestica & Crvena ranka & napušten & 50 & $?$ & - & - & - & - & NEG $^{d}$ \\
\hline 124 & Zlatiborski & Požega & & P. domestica & Crvena ranka & & & & - & - & - & - & NEG \\
\hline 125 & Zlatiborski & Požega & & P. domestica & Crvena ranka & & & & - & - & - & - & NEG \\
\hline 126 & Moravički & Ivanjica & usamljeno & P. cerasifera & & & 6 & - & - & + & - & + & D \\
\hline 127 & Šumadijski & Kragujevac & usamljeno & P. domestica & Crvena ranka & & 10 & - & + & - & - & + & Rec \\
\hline 128 & Kolubarski & Lajkovac & usamljeno & P. domestica & Crvena ranka & & 4 & - & + & - & - & + & Rec \\
\hline 129 & Kolubarski & Lajkovac & usamljeno & P. domestica & Stenley & & 15 & - & + & - & - & + & Rec \\
\hline 130 & Kolubarski & Valjevo & usamljeno & P. domestica & Čačanska rodna & & 2 & - & + & + & - & + & $\mathrm{D}+\mathrm{Rec}$ \\
\hline 131 & Zaječarski & Knjaževac & usamljeno & P. domestica & Crvena ranka & & 15 & - & - & + & - & + & D \\
\hline 132 & Moravički & Čačak & 43 & P. armeniaca & Hungarian Best & intenzivan & 10 & 5 & + & - & - & + & Rec \\
\hline 133 & Moravički & Čačak & & P. armeniaca & Hungarian Best & & & & + & - & - & + & Rec \\
\hline 134 & Moravički & Čačak & 44 & P. armeniaca & Hungarian Best & intenzivan & 15 & 60 & + & - & - & + & Rec \\
\hline 135 & Moravički & Čačak & & P. armeniaca & Hungarian Best & & & & + & - & + & - & $\mathbf{M}$ \\
\hline 136 & Moravički & Čačak & & P. armeniaca & Hungarian Best & & & & + & - & - & + & Rec \\
\hline 137 & Moravički & Čačak & 45 & P. armeniaca & Hungarian Best & intenzivan & 10 & 60 & + & - & - & + & Rec \\
\hline 138 & Moravički & Čačak & & P. armeniaca & Hungarian Best & & & & + & - & - & + & Rec \\
\hline 139 & Moravički & Čačak & 46 & P. domestica & Čačanska rodna & intenzivan & 13 & 100 & + & - & - & + & Rec \\
\hline
\end{tabular}

LEGENDA:

a pozitivna reakcija

- negativna reakcija

c M - PPV-M soj; D - PPV-D soj; Rec - PPV-Rec soj; NEG - nije detektovan virus šarke

PRILOG 1 


\begin{tabular}{|c|c|c|c|c|c|c|c|c|c|c|c|c|c|}
\hline \multirow[b]{3}{*}{$\begin{array}{c}\text { REDNI } \\
\text { BROJ }\end{array}$} & \multirow[b]{3}{*}{ OKRUG } & \multirow[b]{3}{*}{ LOKALITET } & \multirow[b]{3}{*}{$\begin{array}{c}\text { BROJ } \\
\text { ZASADA }\end{array}$} & \multirow[b]{3}{*}{ DOMAĆIN } & \multirow[b]{3}{*}{ SORTA } & \multirow[b]{3}{*}{ TIP ZASADA } & \multicolumn{7}{|c|}{ REZULTATI PCR ANALIZA } \\
\hline & & & & & & & \multirow[b]{2}{*}{$\begin{array}{c}\text { STAROST } \\
\text { ZASADA } \\
\text { (god.) }\end{array}$} & \multirow[b]{2}{*}{$\begin{array}{l}\text { PROCENJENI } \\
\text { \% ZARAZE U } \\
\text { ZASADU }\end{array}$} & \multicolumn{2}{|c|}{ N-ter CP } & \multicolumn{2}{|c|}{ CI } & \multirow[b]{2}{*}{ soJ } \\
\hline & & & & & & & & & $\begin{array}{c}\text { P3M } \\
\text {-P4 }\end{array}$ & $\begin{array}{c}\text { P3D- } \\
\text { P4 }\end{array}$ & $\begin{array}{c}\text { CIP } \\
\mathbf{M}\end{array}$ & $\begin{array}{c}\text { CIP } \\
\text { D }\end{array}$ & \\
\hline 140 & Moravički & Čačak & & P. domestica & Čačanska lepotica & & & & + & - & - & + & $\operatorname{Rec}$ \\
\hline 141 & Moravički & Čačak & & P. domestica & Čačanska lepotica & & & & + & - & - & + & Rec \\
\hline 142 & Moravički & Čačak & 47 & P. armeniaca & Hungarian Best & intenzivan & 5 & 50 & + & - & - & + & $\operatorname{Rec}$ \\
\hline 143 & Moravički & Čačak & & P. armeniaca & Hungarian Best & & & & + & + & - & + & $\mathrm{D}+\operatorname{Rec}$ \\
\hline 144 & Moravički & Čačak & & P. armeniaca & Hungarian Best & & & & + & - & - & + & Rec \\
\hline 145 & Moravički & Čačak & 48 & P. armeniaca & Hungarian Best & intenzivan & 8 & 50 & + & - & - & + & Rec \\
\hline 146 & Moravički & Čačak & & P. armeniaca & Hungarian Best & & & & + & - & - & + & $\operatorname{Rec}$ \\
\hline 147 & Moravički & Čačak & & P. armeniaca & Hungarian Best & & & & + & - & - & + & Rec \\
\hline 148 & Rasinski & Trstenik & 49 & P. domestica & Čačanska rana & poluintenzivan & 8 & 80 & - & + & - & + & D \\
\hline 149 & Rasinski & Trstenik & & P. domestica & Čačanska rana & & & & - & + & - & + & D \\
\hline 150 & Rasinski & Trstenik & & P. domestica & Stenley & & & & - & + & - & + & D \\
\hline 151 & Rasinski & Trstenik & 50 & P. domestica & Stenley & poluintenzivan & 12 & 50 & - & + & - & + & D \\
\hline 152 & Rasinski & Trstenik & & P. domestica & Stenley & & & & - & + & - & + & D \\
\hline 153 & Rasinski & Trstenik & & P. domestica & Stenley & & & & - & + & - & + & $\mathbf{D}$ \\
\hline 154 & Rasinski & Aleksandrovac & 51 & P. domestica & Stenley & intenzivan & 15 & 80 & + & + & - & + & $\mathrm{D}+\operatorname{Rec}$ \\
\hline 155 & Rasinski & Aleksandrovac & & P. domestica & Stenley & & & & + & - & - & + & $\operatorname{Rec}$ \\
\hline 156 & Rasinski & Aleksandrovac & & P. domestica & Stenley & & & & + & + & - & + & $\mathrm{D}+\operatorname{Rec}$ \\
\hline 157 & Rasinski & Brus & 52 & P. domestica & Čačanska rana & poluintenzivan & 20 & 90 & + & - & - & + & $\operatorname{Rec}$ \\
\hline 158 & Rasinski & Brus & & P. domestica & Čačanska rana & & & & + & - & - & + & Rec \\
\hline 159 & Rasinski & Brus & & P. domestica & Stenley & & & & + & + & - & + & $\mathrm{D}+\mathrm{Rec}$ \\
\hline 160 & Rasinski & Brus & 53 & P. domestica & Stenley & ekstenzivan & 30 & 80 & + & - & - & + & $\operatorname{Rec}$ \\
\hline 161 & Rasinski & Brus & & P. domestica & Stenley & & & & + & - & - & + & Rec \\
\hline 162 & Rasinski & Brus & & P. domestica & Stenley & & & & + & - & - & + & Rec \\
\hline 163 & Rasinski & Brus & 54 & P. domestica & Crvena ranka & ekstenzivan & 30 & 90 & + & - & - & + & $\operatorname{Rec}$ \\
\hline 164 & Rasinski & Brus & & P. domestica & Crvena ranka & & & & - & + & - & + & D \\
\hline 165 & Rasinski & Brus & 55 & P. domestica & Stenley & intenzivan & 10 & 80 & - & + & - & + & D \\
\hline 166 & Rasinski & Brus & & P. domestica & Stenley & & & & - & + & - & + & D \\
\hline 167 & Rasinski & Brus & & P. domestica & Stenley & & & & + & - & - & + & Rec \\
\hline
\end{tabular}

LEGENDA:

a pozitivna reakcija

- negativna reakcija

c M - PPV-M soj; D - PPV-D soj; Rec - PPV-Rec soj; NEG - nije detektovan virus šarke 


\begin{tabular}{|c|c|c|c|c|c|c|c|c|c|c|c|c|c|}
\hline \multirow[b]{3}{*}{$\begin{array}{c}\text { REDNI } \\
\text { BROJ }\end{array}$} & \multirow[b]{3}{*}{ OKRUG } & \multirow[b]{3}{*}{ LOKALITET } & \multirow[b]{3}{*}{$\begin{array}{c}\text { BROJ } \\
\text { ZASADA }\end{array}$} & \multirow[b]{3}{*}{ DOMAĆIN } & \multirow[b]{3}{*}{ SORTA } & \multirow[b]{3}{*}{ TIP ZASADA } & \multicolumn{7}{|c|}{ REZULTATI PCR ANALIZA } \\
\hline & & & & & & & \multirow[b]{2}{*}{$\begin{array}{c}\text { STAROST } \\
\text { ZASADA } \\
\text { (god.) }\end{array}$} & \multicolumn{3}{|c|}{ N-ter CP } & \multicolumn{2}{|c|}{ CI } & \multirow[b]{2}{*}{ SOJ } \\
\hline & & & & & & & & $\begin{array}{l}\text { PROCENJENI } \\
\text { \% ZARAZE U } \\
\text { ZASADU }\end{array}$ & $\begin{array}{l}\text { P3M } \\
\text {-P4 }\end{array}$ & $\begin{array}{l}\text { P3D- } \\
\text { P4 }\end{array}$ & $\begin{array}{c}\text { CIP } \\
\text { M }\end{array}$ & $\begin{array}{c}\text { CIP } \\
\text { D }\end{array}$ & \\
\hline 168 & Rasinski & Brus & 56 & P. domestica & Belošljiva & ekstenzivan & 50 & 20 & - & + & - & + & D \\
\hline 169 & Rasinski & Brus & & P. domestica & Belošljiva & & & & - & + & - & + & D \\
\hline 170 & Rasinski & Brus & & P. domestica & Belošljiva & & & & - & + & - & + & D \\
\hline 171 & Toplički & Blace & 57 & P. domestica & Stenley & intenzivan & 7 & 80 & + & - & - & + & Rec \\
\hline 172 & Toplički & Blace & & P. domestica & Stenley & & & & + & - & - & + & Rec \\
\hline 173 & Toplički & Blace & & P. domestica & Stenley & & & & + & - & - & + & $\operatorname{Rec}$ \\
\hline 174 & Toplički & Blace & & P. cerasifera & Krimska žuta & & & & - & + & - & + & D \\
\hline 175 & Toplički & Blace & 58 & P. domestica & Stenley & intenzivan & 8 & 10 & + & - & - & + & Rec \\
\hline 176 & Toplički & Blace & & P. domestica & Stenley & & & & + & - & - & + & Rec \\
\hline 177 & Toplički & Blace & & P. domestica & Stenley & & & & + & - & - & + & Rec \\
\hline 178 & Toplički & Blace & 59 & P. domestica & Stenley & intenzivan & 8 & 90 & + & - & - & + & Rec \\
\hline 179 & Toplički & Blace & & P. domestica & Stenley & & & & + & - & - & + & Rec \\
\hline 180 & Toplički & Blace & & P. domestica & Stenley & & & & + & - & - & + & Rec \\
\hline 181 & Toplički & Blace & 60 & P. domestica & Čačanska lepotica & intenzivan & 4 & 70 & + & - & - & + & Rec \\
\hline 182 & Toplički & Blace & & P. domestica & Moravka & & & & + & + & - & + & D+Rec \\
\hline 183 & Toplički & Blace & & P. domestica & Čačanska lepotica & & & & + & - & - & + & $\operatorname{Rec}$ \\
\hline 184 & Toplički & Kuršumlija & 61 & P. domestica & Stenley & intenzivan & 12 & 100 & + & - & - & + & Rec \\
\hline 185 & Toplički & Kuršumlija & & P. domestica & Stenley & & & & + & - & - & + & Rec \\
\hline 186 & Toplički & Kuršumlija & & P. domestica & Stenley & & & & + & - & - & + & Rec \\
\hline 187 & Toplički & Kuršumlija & 62 & P. domestica & Stenley & intenzivan & 15 & 80 & + & - & + & - & M \\
\hline 188 & Toplički & Kuršumlija & & P. domestica & Stenley & & & & + & - & + & - & $\mathbf{M}$ \\
\hline 189 & Toplički & Kuršumlija & & P. domestica & Čačanska rodna & & & & - & + & - & + & D \\
\hline 190 & Toplički & Kuršumlija & 63 & P. domestica & Stenley & intenzivan & 10 & 60 & + & - & - & + & Rec \\
\hline 191 & Toplički & Kuršumlija & & P. domestica & Stenley & & & & + & - & - & + & $\operatorname{Rec}$ \\
\hline 192 & Toplički & Kuršumlija & & P. domestica & Stenley & & & & + & - & - & + & Rec \\
\hline 193 & Toplički & Prokuplje & 64 & P. domestica & Čačanska rodna & intenzivan & 4 & 90 & - & + & - & + & D \\
\hline 194 & Toplički & Prokuplje & & P. domestica & Čačanska rodna & & & & + & - & - & + & Rec \\
\hline 195 & Toplički & Prokuplje & & P. domestica & Čačanska rodna & & & & - & + & - & + & D \\
\hline
\end{tabular}

LEGENDA:

a pozitivna reakcija

- negativna reakcija

c M - PPV-M soj; D - PPV-D soj; Rec - PPV-Rec soj; NEG - nije detektovan virus šarke 


\begin{tabular}{|c|c|c|c|c|c|c|c|c|c|c|c|c|c|}
\hline \multirow[b]{3}{*}{$\begin{array}{c}\text { REDNI } \\
\text { BROJ }\end{array}$} & \multirow[b]{3}{*}{ OKRUG } & \multirow[b]{3}{*}{ LOKALITET } & \multirow[b]{3}{*}{$\begin{array}{c}\text { BROJ } \\
\text { ZASADA } \\
\end{array}$} & \multirow[b]{3}{*}{ DOMAĆIN } & \multirow[b]{3}{*}{ SORTA } & \multirow[b]{3}{*}{ TIP ZASADA } & \multirow[b]{3}{*}{$\begin{array}{c}\text { STAROST } \\
\text { ZASADA } \\
\text { (god.) }\end{array}$} & \multicolumn{6}{|c|}{ REZULTATI PCR ANALIZA } \\
\hline & & & & & & & & \multicolumn{3}{|c|}{ N-ter CP } & \multicolumn{2}{|c|}{ CI } & \multirow[b]{2}{*}{ SoJ } \\
\hline & & & & & & & & $\begin{array}{c}\text { PROCENJENI } \\
\text { \% ZARAZE U } \\
\text { ZASADU }\end{array}$ & $\begin{array}{l}\text { P3M } \\
\text {-P4 }\end{array}$ & $\begin{array}{c}\text { P3D- } \\
\text { P4 }\end{array}$ & $\begin{array}{c}\text { CIP } \\
\text { M }\end{array}$ & $\begin{array}{c}\text { CIP } \\
\text { D }\end{array}$ & \\
\hline 196 & Toplički & Prokuplje & 65 & P. domestica & Stenley & intenzivan & 10 & 80 & + & - & - & + & Rec \\
\hline 197 & Toplički & Prokuplje & & P. domestica & Stenley & & & & - & + & - & + & D \\
\hline 198 & Toplički & Prokuplje & & P. domestica & Stenley & & & & + & - & - & + & Rec \\
\hline 199 & Toplički & Prokuplje & 66 & P. domestica & Stenley & intenzivan & 12 & 60 & + & - & - & + & Rec \\
\hline 200 & Toplički & Prokuplje & & P. domestica & Stenley & & & & + & - & - & + & Rec \\
\hline 201 & Toplički & Prokuplje & & P. domestica & Stenley & & & & - & + & - & + & D \\
\hline 202 & Kosovo & Leposavić & 67 & P. domestica & Čačanska rodna & ekstenzivan & 6 & 40 & + & - & - & + & Rec \\
\hline 203 & Kosovo & Leposavić & & P. domestica & Čačanska rodna & & & & - & + & - & + & D \\
\hline 204 & Kosovo & Leposavić & & P. domestica & Čačanska rodna & & & & + & - & - & + & Rec \\
\hline 205 & Macvanski & Vladimirci & 68 & P. domestica & Požegača & poluintenzivan & 15 & 50 & + & + & - & + & D+Rec \\
\hline 206 & Macvanski & Vladimirci & & P. domestica & Požegača & & & & + & - & - & + & Rec \\
\hline 207 & Macvanski & Vladimirci & & P. domestica & Požegača & & & & + & - & - & + & Rec \\
\hline 208 & Macvanski & Vladimirci & 69 & P. domestica & Čačanska rodna & intenzivan & 4 & 5 & - & - & - & - & NEG \\
\hline 209 & Macvanski & Vladimirci & & P. domestica & Čačanska rodna & & & & - & - & - & - & NEG \\
\hline 210 & Macvanski & Šabac & 70 & P. domestica & Čačanska rodna & intenzivan & 10 & 70 & + & - & + & + & M+Rec \\
\hline 211 & Macvanski & Šabac & & P. domestica & Čačanska rodna & & & & + & - & - & + & $\operatorname{Rec}$ \\
\hline 212 & Macvanski & Šabac & & P. domestica & Čačanska rodna & & & & + & - & - & + & $\operatorname{Rec}$ \\
\hline 213 & Macvanski & Šabac & 71 & P. domestica & Stenley & intenzivan & 12 & 60 & + & - & + & + & $\mathrm{M}+\mathrm{Rec}$ \\
\hline 214 & Macvanski & Šabac & & P. domestica & Stenley & & & & + & + & + & + & $M+D$ \\
\hline 215 & Macvanski & Šabac & & P. domestica & Stenley & & & & - & + & - & + & D \\
\hline 216 & Nisavski & Aleksinac & 72 & P. domestica & Crvena ranka & ekstenzivan & 15 & 100 & - & + & - & + & D \\
\hline 217 & Nisavski & Aleksinac & & P. domestica & Crvena ranka & & & & - & + & - & + & D \\
\hline 218 & Nisavski & Aleksinac & & P. domestica & Crvena ranka & & & & + & - & - & + & Rec \\
\hline 219 & Nisavski & Aleksinac & 73 & P. domestica & Stenley & intenzivan & 12 & 100 & + & - & - & + & Rec \\
\hline 220 & Nisavski & Aleksinac & & P. domestica & Stenley & & & & + & - & - & + & Rec \\
\hline 221 & Nisavski & Aleksinac & & P. domestica & Stenley & & & & + & - & - & + & Rec \\
\hline 222 & Nisavski & Aleksinac & 74 & P. domestica & Stenley & poluintenzivan & 8 & 90 & + & - & + & - & $\mathbf{M}$ \\
\hline 223 & Nisavski & Aleksinac & & P. domestica & Stenley & & & & - & + & - & + & D \\
\hline
\end{tabular}

LEGENDA:

a pozitivna reakcija

- negativna reakcija

c M - PPV-M soj; D - PPV-D soj; Rec - PPV-Rec soj; NEG - nije detektovan virus šarke 


\begin{tabular}{|c|c|c|c|c|c|c|c|c|c|c|c|c|c|}
\hline \multirow[b]{3}{*}{$\begin{array}{c}\text { REDNI } \\
\text { BROI }\end{array}$} & \multirow[b]{3}{*}{ OKRUG } & \multirow[b]{3}{*}{ LOKALITET } & \multirow[b]{3}{*}{$\begin{array}{c}\text { BROJ } \\
\text { ZASADA }\end{array}$} & \multirow[b]{3}{*}{ DOMAĆIN } & \multirow[b]{3}{*}{ SORTA } & \multirow[b]{3}{*}{ TIP ZASADA } & \multicolumn{7}{|c|}{ REZULTATI PCR ANALIZA } \\
\hline & & & & & & & \multirow[b]{2}{*}{$\begin{array}{c}\text { STAROST } \\
\text { ZASADA } \\
\text { (god.) }\end{array}$} & \multicolumn{3}{|c|}{ N-ter CP } & \multicolumn{2}{|c|}{ CI } & \multirow[b]{2}{*}{ SOJ } \\
\hline & & & & & & & & $\begin{array}{c}\text { PROCENJENI } \\
\text { \% ZARAZE U } \\
\text { ZASADU }\end{array}$ & $\begin{array}{c}\text { P3M } \\
- \text { P4 }\end{array}$ & $\begin{array}{c}\text { P3D- } \\
\text { P4 }\end{array}$ & $\begin{array}{c}\text { CIP } \\
\mathbf{M}\end{array}$ & $\begin{array}{c}\text { CIP } \\
\text { D }\end{array}$ & \\
\hline 224 & Nisavski & Aleksinac & & P. domestica & Stenley & & & & - & + & - & + & D \\
\hline 225 & Pirotski & Babušnica & 75 & P. domestica & Crvena ranka & poluintenzivan & 8 & 70 & - & + & - & + & D \\
\hline 226 & Pirotski & Babušnica & & P. domestica & Stenley & & & & + & + & - & + & D+Rec \\
\hline 227 & Pirotski & Babušnica & & P. domestica & Čačanska lepotica & & & & - & + & - & + & D \\
\hline 228 & Nis & Niška banja & 76 & P. domestica & Stenley & ekstenzivan & 15 & 80 & + & + & - & + & D+Rec \\
\hline 229 & Nis & Niška banja & & P. domestica & Stenley & & & & - & + & - & + & D \\
\hline 230 & Nis & Niška banja & & P. domestica & Stenley & & & & + & + & - & + & D+Rec \\
\hline 231 & Pirotski & Niška banja & 77 & P. domestica & Stenley & ekstenzivan & 30 & 100 & - & + & - & + & D \\
\hline 232 & Pirotski & Niška banja & & P. domestica & Stenley & & & & - & + & - & + & D \\
\hline 233 & Pirotski & Niška banja & & P. domestica & Stenley & & & & - & + & - & + & D \\
\hline 234 & Pirotski & Bela Palanka & 78 & P. domestica & Belošljiva & ekstenzivan & 2 & 60 & - & + & - & + & D \\
\hline 235 & Pirotski & Bela Palanka & & P. domestica & Belošljiva & & & & - & + & - & + & D \\
\hline 236 & Pirotski & Bela Palanka & & P. domestica & Belošljiva & & & & - & + & - & + & D \\
\hline 237 & Pirotski & Pirot & 79 & P. domestica & Stenley & intenzivan & 8 & 80 & - & + & - & + & D \\
\hline 238 & Pirotski & Pirot & & P. domestica & Stenley & & & & - & + & - & + & D \\
\hline 239 & Pirotski & Pirot & & P. domestica & Stenley & & & & - & + & - & + & D \\
\hline 240 & Pirotski & Pirot & 80 & P. domestica & Stenley & intenzivan & 12 & 100 & - & + & - & + & D \\
\hline 241 & Pirotski & Pirot & & P. domestica & Stenley & & & & - & + & - & + & D \\
\hline 242 & Pirotski & Pirot & & P. domestica & Stenley & & & & - & + & - & + & D \\
\hline 243 & Pirotski & Pirot & 81 & P. domestica & Čačanska rodna & intenzivan & 8 & 90 & + & - & - & + & Rec \\
\hline 244 & Pirotski & Pirot & & P. domestica & Stenley & & & & - & + & - & + & D \\
\hline 245 & Pirotski & Pirot & & P. domestica & Čačanska rodna & & & & + & - & - & + & Rec \\
\hline 246 & Pirotski & Pirot & & P. armeniaca & / & & & & - & + & - & + & D \\
\hline 247 & Jablanicki & Vlasotince & 82 & P. domestica & Požegača & napušten & 50 & 60 & + & - & - & + & Rec \\
\hline 248 & Jablanicki & Vlasotince & & P. domestica & Požegača & & & & + & - & - & + & Rec \\
\hline 249 & Jablanicki & Vlasotince & & P. domestica & Požegača & & & & - & + & - & + & D \\
\hline 250 & Toplički & Kuršumlija & 83 & P. domestica & Stenley & intenzivan & 6 & 90 & + & - & - & + & Rec \\
\hline 251 & Toplički & Kuršumlija & & P. domestica & Stenley & & & & + & - & - & + & Rec \\
\hline
\end{tabular}

LEGENDA:

+ pozitivna reakcija

- negativna reakcija

c M - PPV-M soj; D - PPV-D soj; Rec - PPV-Rec soj; NEG - nije detektovan virus šarke 


\begin{tabular}{|c|c|c|c|c|c|c|c|c|c|c|c|c|c|}
\hline \multirow[b]{3}{*}{$\begin{array}{c}\text { REDNI } \\
\text { BROJ }\end{array}$} & \multirow[b]{3}{*}{ OKRUG } & \multirow[b]{3}{*}{ LOKALITET } & \multirow[b]{3}{*}{$\begin{array}{c}\text { BROJ } \\
\text { ZASADA }\end{array}$} & \multirow[b]{3}{*}{ DOMAĆIN } & \multirow[b]{3}{*}{ SORTA } & \multirow[b]{3}{*}{ TIP ZASADA } & \multicolumn{7}{|c|}{ REZULTATI PCR ANALIZA } \\
\hline & & & & & & & \multirow[b]{2}{*}{$\begin{array}{c}\text { STAROST } \\
\text { ZASADA } \\
\text { (god.) }\end{array}$} & \multirow[b]{2}{*}{$\begin{array}{c}\text { PROCENJENI } \\
\text { \% ZARAZE U } \\
\text { ZASADU }\end{array}$} & \multicolumn{2}{|c|}{ N-ter CP } & \multicolumn{2}{|c|}{ CI } & \multirow[b]{2}{*}{ soj } \\
\hline & & & & & & & & & $\begin{array}{c}\text { P3M } \\
\text {-P4 }\end{array}$ & $\begin{array}{c}\text { P3D- } \\
\text { P4 }\end{array}$ & $\begin{array}{c}\text { CIP } \\
\text { M }\end{array}$ & $\begin{array}{c}\text { CIP } \\
\text { D }\end{array}$ & \\
\hline 252 & Toplički & Kuršumlija & & P. domestica & Stenley & & & & + & - & - & + & $\operatorname{Rec}$ \\
\hline 253 & Jablanicki & Leskovac & 84 & P. domestica & Stenley & napušten & 40 & 80 & + & - & - & + & Rec \\
\hline 254 & Jablanicki & Leskovac & & P. domestica & Stenley & & & & + & - & - & + & Rec \\
\hline 255 & Jablanicki & Leskovac & & P. domestica & Stenley & & & & + & - & - & + & $\operatorname{Rec}$ \\
\hline 256 & Zlatiborski & Užice & 85 & P. domestica & Crvena ranka & ekstenzivan & 10 & 70 & + & - & - & + & Rec \\
\hline 257 & Zlatiborski & Užice & & P. domestica & Crvena ranka & & & & + & - & - & + & Rec \\
\hline 258 & Zlatiborski & Užice & & P. domestica & Čačanska rodna & & & & + & - & - & + & $\operatorname{Rec}$ \\
\hline 259 & Zlatiborski & Nova Varoš & 86 & P. domestica & Požegača & ekstenzivan & 30 & 100 & + & - & - & + & $\operatorname{Rec}$ \\
\hline 260 & Zlatiborski & Nova Varoš & & P. domestica & Požegača & & & & + & - & - & + & Rec \\
\hline 261 & Zlatiborski & Nova Varoš & & P. domestica & Požegača & & & & + & - & - & + & Rec \\
\hline 262 & Zlatiborski & Nova Varoš & 87 & P. domestica & Požegača & ekstanzivan & 40 & 80 & + & - & - & + & Rec \\
\hline 263 & Zlatiborski & Nova Varoš & & P. domestica & Požegača & & & & + & - & - & + & $\operatorname{Rec}$ \\
\hline 264 & Zlatiborski & Nova Varoš & & P. domestica & Požegača & & & & + & - & - & + & Rec \\
\hline 265 & Zlatiborski & Nova Varoš & 88 & P. domestica & Crvena ranka & ekstenzivan & 20 & 80 & + & - & - & + & Rec \\
\hline 266 & Zlatiborski & Nova Varoš & & P. domestica & Crvena ranka & & & & + & - & - & + & Rec \\
\hline 267 & Zlatiborski & Nova Varoš & & P. domestica & Crvena ranka & & & & + & - & - & + & $\operatorname{Rec}$ \\
\hline 268 & Zlatiborski & Nova Varoš & 89 & P. domestica & Čačanska rodna & poluintenzivan & 20 & 70 & - & + & - & + & D \\
\hline 269 & Zlatiborski & Nova Varoš & & P. domestica & Čačanska rodna & & & & + & - & - & + & Rec \\
\hline 270 & Zlatiborski & Nova Varoš & & P. domestica & Čačanska rodna & & & & + & - & - & + & Rec \\
\hline 271 & Zlatiborski & Nova Varoš & 90 & P. domestica & Požegača & napušten & 50 & 50 & + & - & - & + & Rec \\
\hline 272 & Zlatiborski & Nova Varoš & & P. domestica & Požegača & & & & + & - & - & + & $\operatorname{Rec}$ \\
\hline 273 & Zlatiborski & Nova Varoš & & P. domestica & Požegača & & & & + & - & - & + & Rec \\
\hline 274 & Zlatiborski & Prijepolje & 91 & P. domestica & Čačanska rodna & intenzivan & 10 & 90 & + & - & - & + & Rec \\
\hline 275 & Zlatiborski & Prijepolje & & P. domestica & Čačanska rodna & & & & + & - & - & + & Rec \\
\hline 276 & Zlatiborski & Prijepolje & & P. domestica & Čačanska rodna & & & & + & - & - & + & Rec \\
\hline 277 & Zlatiborski & Prijepolje & 92 & P. domestica & Stenley & poluintezivan & 15 & 50 & + & - & - & + & Rec \\
\hline 278 & Zlatiborski & Prijepolje & & P. domestica & Derosavka & & & & + & - & - & + & $\operatorname{Rec}$ \\
\hline 279 & Zlatiborski & Prijepolje & & P. domestica & Čačanska rodna & & & & + & - & - & + & Rec \\
\hline
\end{tabular}

LEGENDA:

a pozitivna reakcija

- negativna reakcija

c M - PPV-M soj; D - PPV-D soj; Rec - PPV-Rec soj; NEG - nije detektovan virus šarke 


\begin{tabular}{|c|c|c|c|c|c|c|c|c|c|c|c|c|c|}
\hline \multirow[b]{3}{*}{$\begin{array}{c}\text { REDNI } \\
\text { BROJ }\end{array}$} & \multirow[b]{3}{*}{ OKRUG } & \multirow[b]{3}{*}{ LOKALITET } & \multirow[b]{3}{*}{$\begin{array}{c}\text { BROJ } \\
\text { ZASADA }\end{array}$} & \multirow[b]{3}{*}{ DOMAĆIN } & \multirow[b]{3}{*}{ SORTA } & \multirow[b]{3}{*}{ TIP ZASADA } & \multirow[b]{3}{*}{$\begin{array}{c}\text { STAROST } \\
\text { ZASADA } \\
\text { (god.) }\end{array}$} & \multicolumn{6}{|c|}{ REZULTATI PCR ANALIZA } \\
\hline & & & & & & & & \multicolumn{3}{|c|}{ N-ter CP } & \multicolumn{2}{|c|}{ CI } & \multirow[b]{2}{*}{ SoJ } \\
\hline & & & & & & & & $\begin{array}{c}\text { PROCENJENI } \\
\% \text { ZARAZE U } \\
\text { ZASADU } \\
\end{array}$ & $\begin{array}{c}\text { P3M } \\
- \text { P4 }\end{array}$ & $\begin{array}{c}\text { P3D- } \\
\text { P4 }\end{array}$ & $\begin{array}{c}\text { CIP } \\
\text { M }\end{array}$ & $\begin{array}{c}\text { CIP } \\
\text { D }\end{array}$ & \\
\hline 280 & Zlatiborski & Prijepolje & 93 & P. domestica & Požegača & napušten & 60 & 80 & + & - & - & + & $\operatorname{Rec}$ \\
\hline 281 & Zlatiborski & Prijepolje & & P. domestica & Požegača & & & & + & - & - & + & Rec \\
\hline 282 & Zlatiborski & Prijepolje & & P. domestica & Požegača & & & & + & - & - & + & Rec \\
\hline 283 & Zlatiborski & Nova Varoš & 94 & P. domestica & Derosavka & napušten & 20 & 5 & + & - & - & + & $\operatorname{Rec}$ \\
\hline
\end{tabular}


PRILOG 2: Sekvence izolata RS-67pl i PPV-Rec izolata iz okoline eksperimentalnog zasada
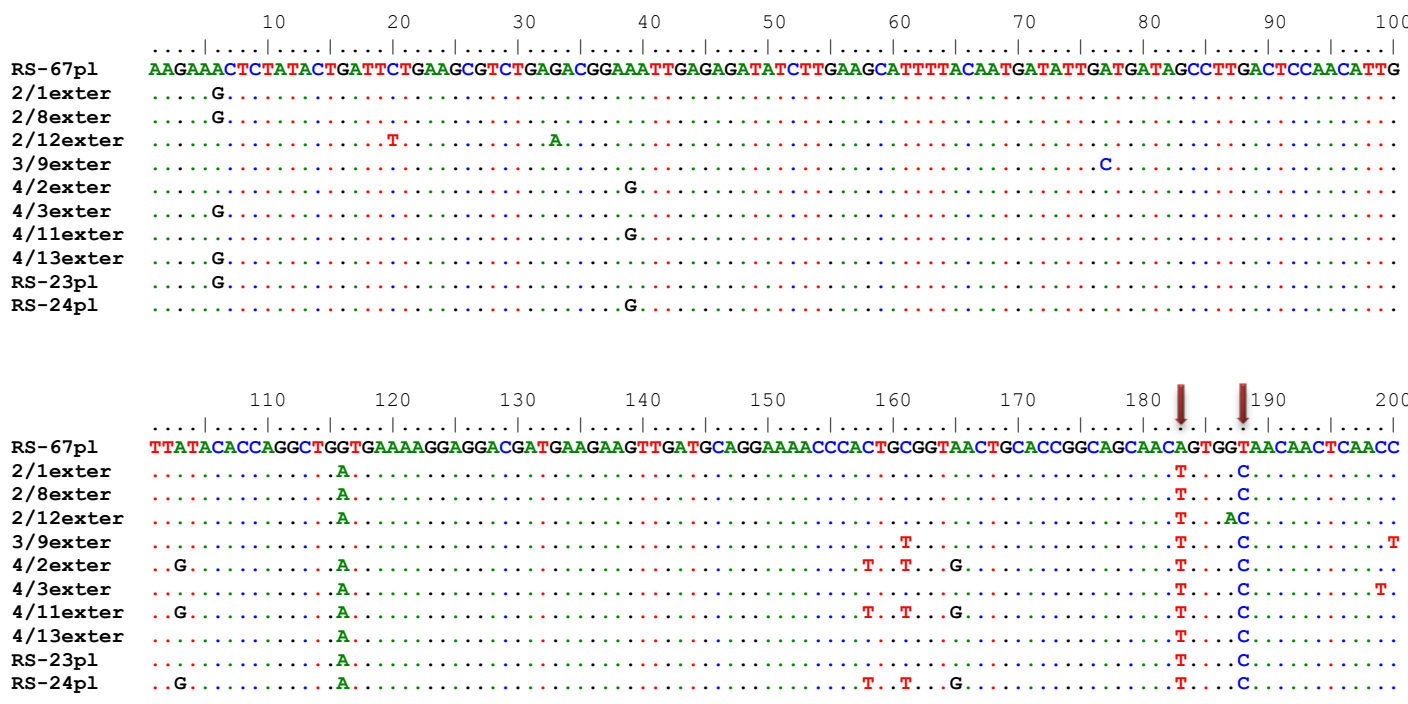

$\begin{array}{rrrrrrrrr}210 & 220 & 230 & 240 & 250 & 260 & 270 & 280 & 290\end{array}$

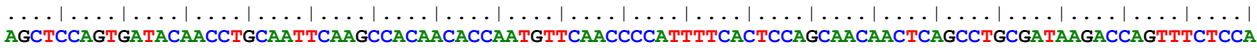
$2 / 8$ exter

2/12exter

$3 / 9$ exter

$4 / 2$ exter

$4 / 3$ exter

$4 / 11$ exter

$4 / 13$ exter

RS-23pl

RS-24pl

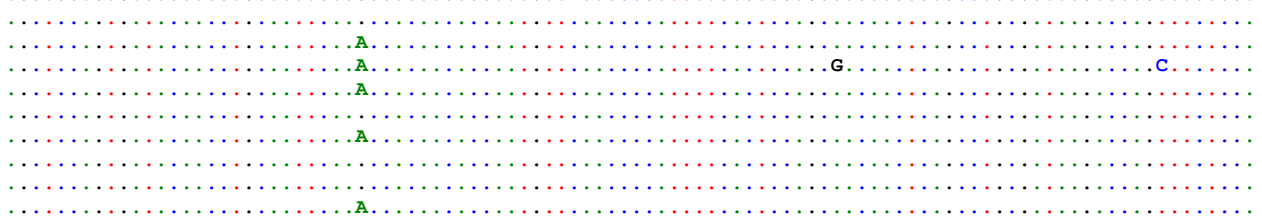

$\begin{array}{rrrrrrrrr}310 & 320 & 330 & 340 & 350 & 360 & 370 & 380 & 390\end{array}$

RS-67pl

2/lexter

$2 / 8$ exter

2/12exter

$3 / 9$ exter

4/2exter

$4 / 11$ exter

4/11exter

$4 / 13$ exter

RS-23p1

RS-24p1

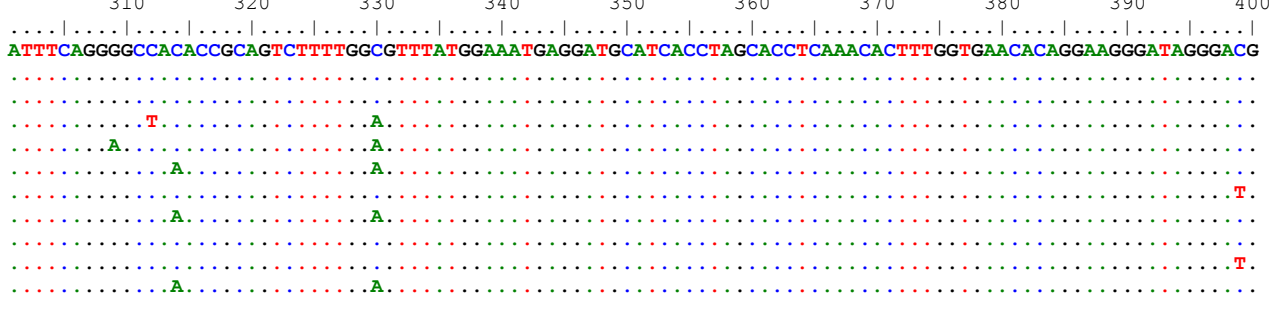

$410 \quad 420$

TCGATGCAGGATCGATTGGAACTTTCG

RS-67pl

$2 / 1$ exter

2/8exter

/12exter

/9exter

$4 / 2$ exter

$4 / 3$ exter

$4 / 11$ exte

$4 / 13$ exter

RS-23pl

RS-24pl 
PRILOG 3: Sekvence izolata RS-68pl i PPV-D izolata iz okoline eksperimentalnog zasada

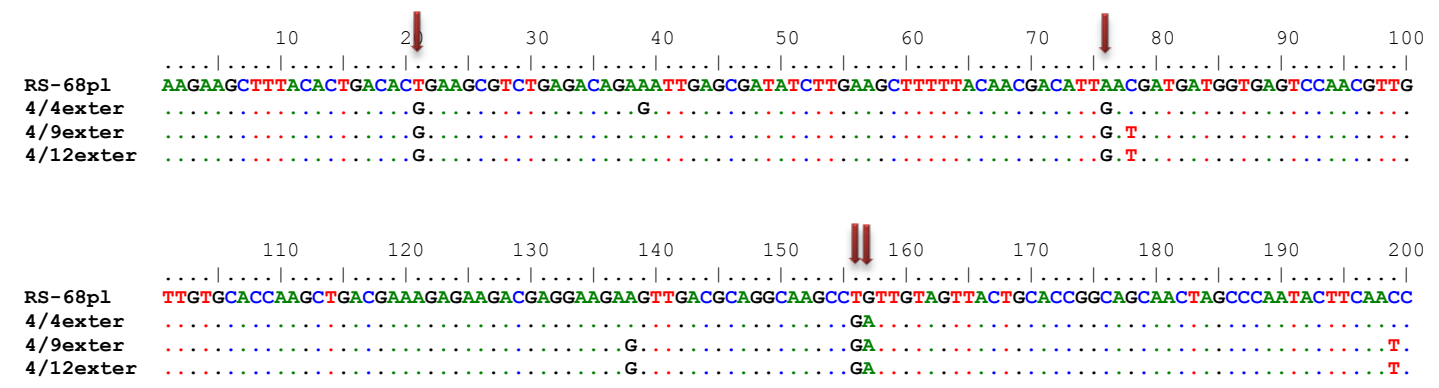

$\begin{array}{lllllllll}210 & 220 & 230 & 240 & 250 & 260 & 270 & 280 & 290\end{array}$

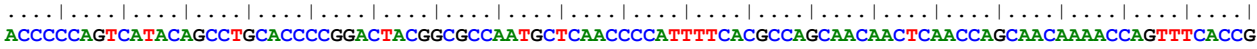
. т. . А . . . . . . .

$4 / 4$ exter

$4 / 9$ exter

$4 / 12$ exter

т. . . .

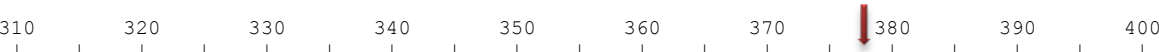

RS-68p1 ATGTCAAGACCTCAACTGCAAACTTTTGGAACACATGGTAATGAGGATGCCTCACCTAGCAACTCAAACGCGCTAGTCAACACAAACAGAGACAGGGACG

$4 / 4$ exter

$4 / 9$ exter

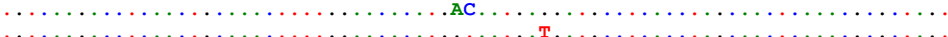

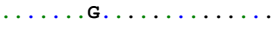

410

420

RS-68pl TCGATGCAGGATCAATTGGACTTTCA

$4 / 4$ exter

$4 / 9$ exter

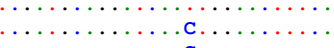

$4 / 12$ exter 
PRILOG 4: Sekvence PPV-Rec izolata sa inokulisanih i novozaraženih stabala iz 2009. godine upoređene sa sekvencom izolata RS-67pl

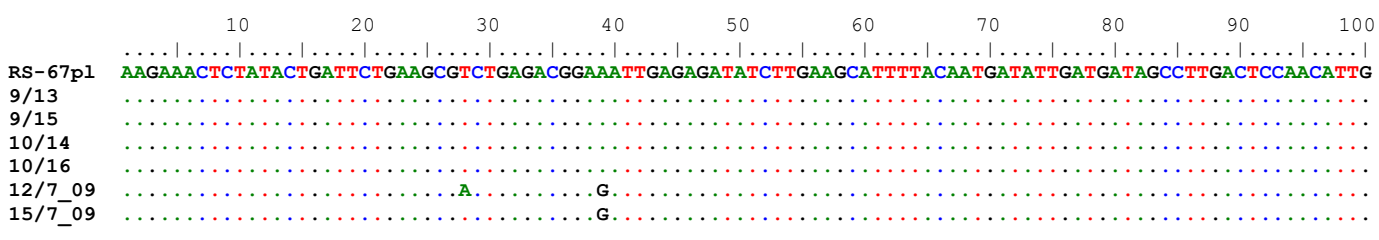

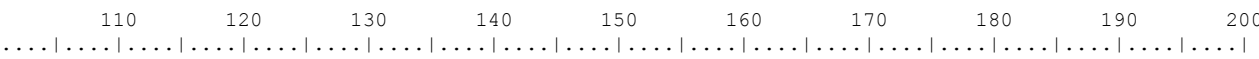

RS-67p1 TTATACACCAGGCTGGTGAAAAGGAGGACGATGAAGAAGTTGATGCAGGAAAACCCACTGCGGTAACTGCACCGGCAGCAACAGTGGTAACAACTCAACC $9 / 13$

$10 / 1$

$10 / 16$

$12 / 7$

$12 / 7$ - 15

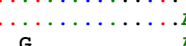

T. T...G.

T....

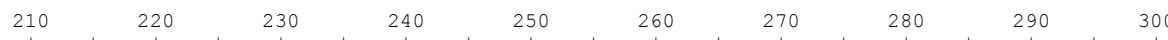

RS-67p1 AGCTCCAGTGATACACCTGCAATTCAAGCCACAACACCAATGTTCAACCCCATTTTCACTCCAGCAACAACTCAGCCTGCGATAGACCAGTTTCTCCA

$9 / 13$

$10 / 14$

$10 / 16$

$12 / 709$

$15 / 7_{-}^{-} 09$

340

350

360

370

380

390

400

RS-67p1 ATTTCAGGGGCCACACCGCAGTCTTTTGGCGTTTATGGAATGAGGATGCATCACCTAGCACCTCAAACACTTTGGTGAACACAGGAAGGGATAGGGACG

$9 / 13$

$9 / 15$

$10 / 14$

$10 / 16$

$12 / 7 \quad 09$

$15 / 7-09$

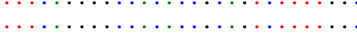

....................

$410 \quad 420$

RS-67pl TCGATGCAGGATCGATTGGAACTTTCG

$9 / 13$

$9 / 15$

$10 / 14$

$12 / 7+09$
$15 / 7 \_09$ 
PRILOG 5: Sekvence PPV-D izolata sa inokulisanih i novozaraženog stabla iz 2009. godine upoređene sa sekvencom izolata RS-68pl

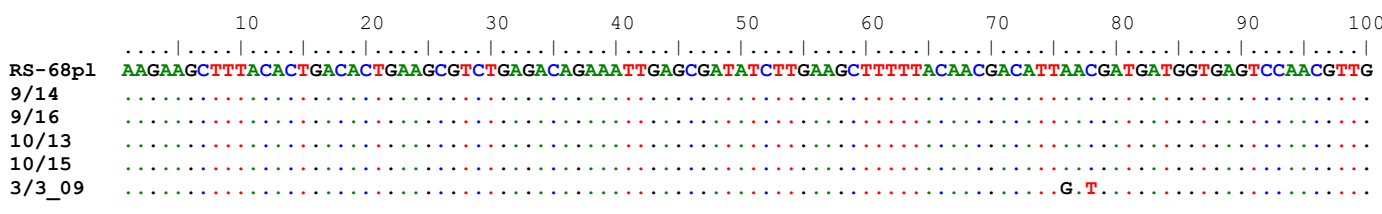

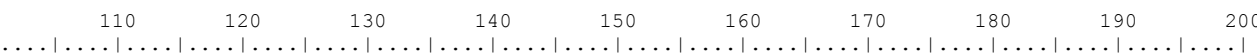
RS-68p1 TTGTGCACCAAGCTGACGAAAGAGAAGACGAGGA GAAGTTGACGCAGGCAAGCCTGTTGTAGTTACTGCACCGGCAGCAACTAGCCCAATACTTCAACC $9 / 14$

$9 / 16$

$10 / 13$

$3 / 309$

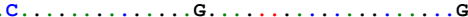

$\begin{array}{rrrrrrrrr}210 & 220 & 230 & 240 & 250 & 260 & 270 & 280 & 290\end{array}$

$\ldots$ ССТССа $\ldots . \ldots .|\ldots| \ldots|\ldots| \ldots|\ldots| \ldots|\ldots| \ldots|\ldots| \ldots|\ldots| \ldots|\ldots| \ldots|\ldots| \ldots|\ldots| \ldots|\ldots| \ldots|\ldots|$

RS-68pl ACCTCCAGIC

$9 / 14 \quad \ldots$. . . . .

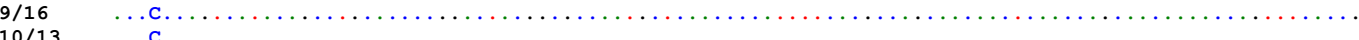

(10/13

$1 / 309$

C.

$9 / 14$

$10 / 13$

$10 / 15$

3/3_09

G...A.

410

RS-68p1 TCGATGCAGGATCAATTGGAACTTTCA

$9 / 14$

$9 / 16$

$10 / 15$

$3 / 309$ 
PRILOG 6: Broj uhvaćenih krilatih formi različitih vrsta lisnih vaši primenom Sticky-shoot metode u eksperimentalnom zasadu šljive u 2009. godini

\begin{tabular}{|c|c|c|c|c|c|c|c|c|c|c|c|c|c|c|c|c|c|c|}
\hline \multirow[b]{2}{*}{ Vrsta lisnih vaši } & \multicolumn{17}{|c|}{ Intervali nanošenja aerosola } & \multirow[b]{2}{*}{ 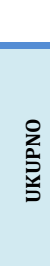 } \\
\hline & 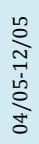 & $\begin{array}{l}\stackrel{2}{\rho} \\
\frac{1}{n} \\
\stackrel{\rho}{\rho} \\
\stackrel{m}{n}\end{array}$ & 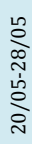 & 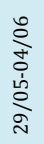 & 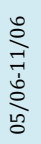 & 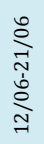 & 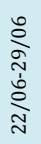 & 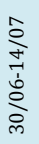 & 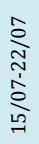 & 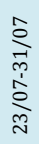 & $\begin{array}{l}\stackrel{\infty}{0} \\
\stackrel{0}{0} \\
0 \\
\infty \\
\stackrel{0}{0} \\
-1\end{array}$ & 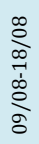 & 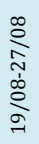 & 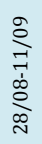 & 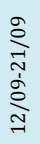 & 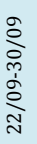 & 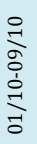 & \\
\hline Acyrthosiphon pisum & 1 & 1 & 2 & & & & & & & & & & & & & & & 4 \\
\hline Acyrthosiphon spp. & & 1 & & & & & & 1 & & & & & & & 1 & & & 3 \\
\hline Anoecia corni & 1 & & & 1 & 4 & & 2 & 1 & & & & & & & & 1 & 2 & 12 \\
\hline Anoecia spp. & 2 & & & & 1 & & & & & & & & & & 1 & & & 4 \\
\hline Aphididae & & 2 & & 1 & & & & & & 1 & & 1 & & & 1 & & & 6 \\
\hline Aphis craccivora & & & 1 & & 1 & 1 & & & & & & 5 & & 1 & 4 & & & 13 \\
\hline Aphis fabae & & 10 & 5 & & 8 & 5 & 3 & 3 & 1 & 1 & & 3 & & & & & & 39 \\
\hline Aphis pomi/spiraecola & 2 & 7 & 2 & 6 & 7 & 1 & 1 & & & & & & & & 3 & 2 & 1 & 32 \\
\hline Aphis spp. & 9 & 30 & 24 & 11 & 29 & 10 & 4 & 5 & 1 & 2 & 9 & 5 & 3 & 1 & 14 & & 2 & 159 \\
\hline Atheroides serrulatus & & 1 & 2 & & & & & & & & & & & & & 1 & & 4 \\
\hline Aulacorthum solani & & & 1 & & & & & & & & & & & & & & & 1 \\
\hline Brachycaudus cardui & 2 & 4 & 1 & & 2 & & & & & & & & & & & & & 9 \\
\hline Brachycaudus helychrisi & & & & & & & 1 & & & & & & & & & 1 & & 2 \\
\hline Brachycaudus spp. & 3 & 6 & 5 & 1 & 4 & & & & & & 1 & & & & 2 & 2 & 1 & 25 \\
\hline Capitophorus eleagni & & & & & & & 58 & & & & & & & & & & & 58 \\
\hline Capitophorus spp. & & 1 & & & & & & 1 & & & & & & & & & & 2 \\
\hline Cavariella spp. & & 2 & & & & & & & & & & & & & & & & 2 \\
\hline Chaitophorus spp. & & & 4 & & & & & & & & & & & & & & & 4 \\
\hline Cinara sp. & & & 1 & & & & & & & & & & & & & & & 1 \\
\hline Dysaphis spp. & & & & & & & & & & & & & & & & 3 & & 3 \\
\hline Eulachnus sp. & 1 & & & & & & & & & & & & & & & & & 1 \\
\hline Hyadaphis foeniculi & 1 & 8 & & & & & 1 & & & & & & & & & & & 10 \\
\hline Hyadaphis polonica & & & & & & & & & & & & & & & 2 & & & 2 \\
\hline Hyalopterus pruni & & 1 & 1 & & & & 1 & 1 & 1 & 1 & 2 & 2 & & & & & & 10 \\
\hline Hyperomyzus sp. & & & 1 & & & & & & & & & & & & & & & 1 \\
\hline Lipaphis erysimi & & & & & & & & 1 & 2 & & & & & & & & & 3 \\
\hline Macrosiphum rosae & & & 1 & & & & & & & & & & & & 1 & & & 2 \\
\hline Macrosiphoniella spp. & & & & & & & & & & & & & & & 1 & 1 & & 2 \\
\hline Macrosiphini & & & & 1 & 1 & & & & & & & & & & & & & 2 \\
\hline Metopolophium dirhodum & & & 1 & & & & & & & & & & & & & & & 1 \\
\hline Myzocallis spp. & 1 & 44 & 8 & 2 & 5 & 1 & & 1 & 1 & & & & & & & & & 63 \\
\hline Myzodium modestum & & & & & & & & & & & & & & & & 2 & & 2 \\
\hline Myzus persicae & & 1 & & 1 & & & & & & & & 1 & & & & & & 3 \\
\hline Pemphigidae & & & & & & & & & & & & & & 3 & & & & 3 \\
\hline Pemphigus spp. & & & 2 & 2 & 3 & & & & & & & & & & 13 & & & 20 \\
\hline Periphyllus spp. & & 1 & & & & & & & & & & & & & & & & 1 \\
\hline Phorodon humuli & & 4 & 15 & 1 & & & & & & & & & & & & & & 20 \\
\hline Phyllaphis fagi & 1 & 2 & & & & & & & & & 1 & & & & 2 & & & 6 \\
\hline Rhopalomyzus poae & & & & & & & & & & & & & & & & & 1 & 1 \\
\hline Rhopalosiphum maidis & & & & & & & & & & & & 3 & 1 & 1 & 1 & 1 & & 7 \\
\hline Rhopalosiphum nymphaeae & & 1 & & & & & & & & & & & & & & & & 1 \\
\hline Rhopalosiphum padi & & & & & & & 1 & & 1 & 1 & 1 & 23 & 5 & 8 & 14 & 3 & 1 & 58 \\
\hline Schizaphis graminum & & 3 & 1 & 1 & 2 & 3 & & & & & & 2 & & & 1 & & & 13 \\
\hline Semiaphis spp. & & 1 & & & & 1 & & & & & & & & & 6 & 7 & 1 & 16 \\
\hline Sipha maydis & & & & & 1 & 2 & & & & & & & & & & & & 3 \\
\hline Sipha spp. & 1 & & 1 & & & & 1 & & & & & 1 & & 1 & 2 & & & 7 \\
\hline Sitobion avenae & & & & 1 & & 2 & & & & & & & & & & & 1 & 4 \\
\hline Tetraneura spp. & & 1 & 1 & 1 & 1 & & & & & & & & & 3 & 1 & & & 8 \\
\hline Thelaxes spp. & & & & & & & & & & 1 & & & & & & & & 1 \\
\hline Therioaphis spp. & & 1 & & & 1 & & & 1 & & & 3 & & & & & & & 6 \\
\hline Therioaphis trifolii & & 2 & 3 & & 1 & & 1 & 3 & & & & 9 & 4 & & 22 & 1 & & 46 \\
\hline Uroleucon spp. & & & 1 & & 1 & & & & & & & & & & & & & 2 \\
\hline UKUPNO & 25 & 135 & 84 & 30 & 72 & 26 & 74 & 18 & 7 & 7 & 17 & 55 & 13 & 18 & 92 & 25 & 10 & 708 \\
\hline
\end{tabular}


PRILOG 7: Sekvence PPV-Rec izolata sa inokulisanih, kao i zaraženih stabala iz 2010. godine upoređene sa sekvencom izolata RS-67pl
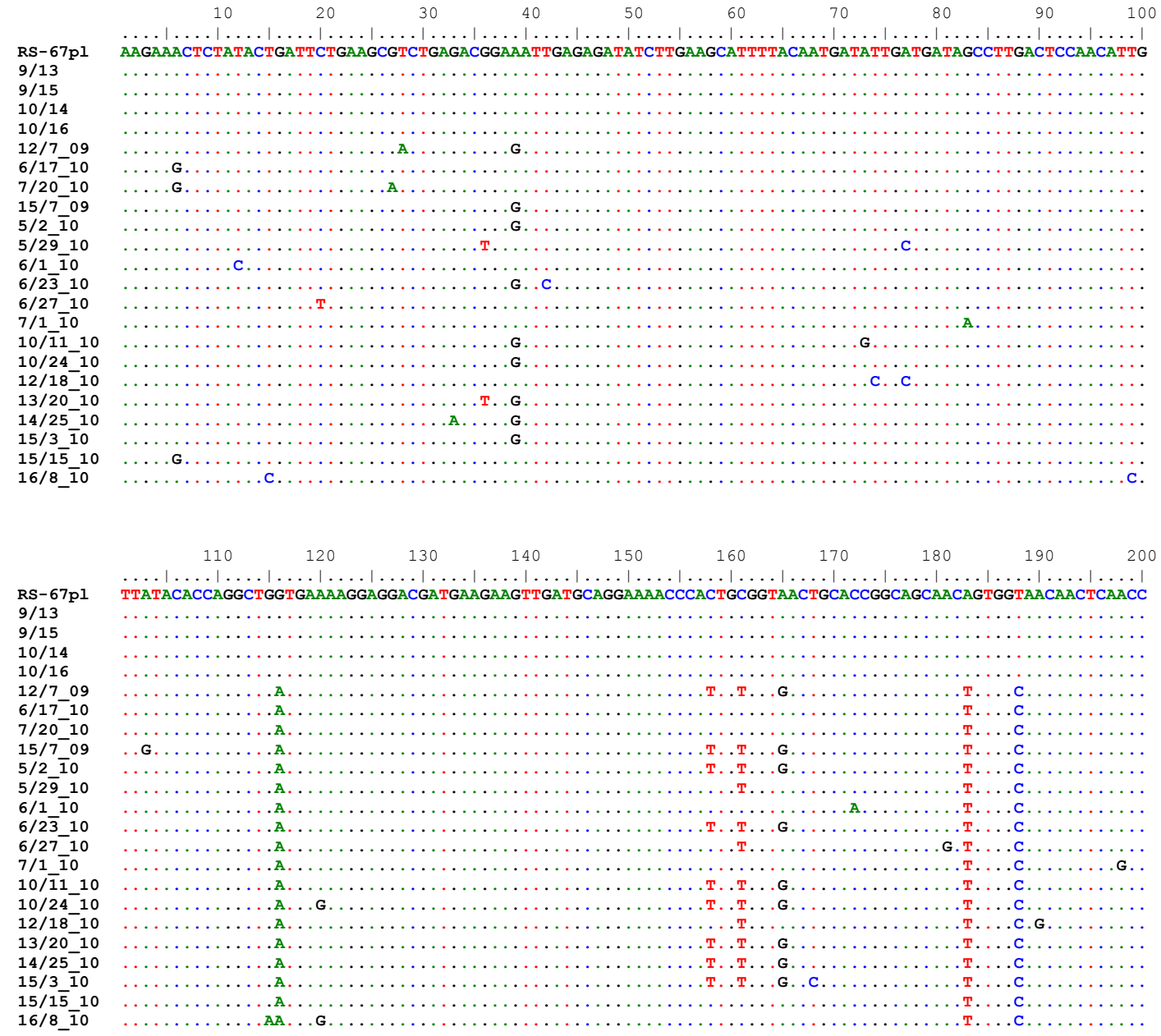

$\begin{array}{llllllllll}210 & 220 & 230 & 240 & 250 & 260 & 270 & 280 & 290 & 300\end{array}$ RS $-67 \mathrm{pl}$ RS-6
$9 / 13$
$9 / 15$

$10 / 14$

$10 / 16$

12/7_09

6/17_10

$7 / 20$

$15 / 7-09$

$5 / 2 \overline{9} 10$

$6 / 1$ - 10

$6 / 2 \overline{3} \_10$

$6 / 27-10$

$7 / 1-10$

10/11_10

$10 / 24$

$12 / 18$

$13 / 20$

$14 / 25$

$15 / 3$

$15 / 1510$

16/8_ 10

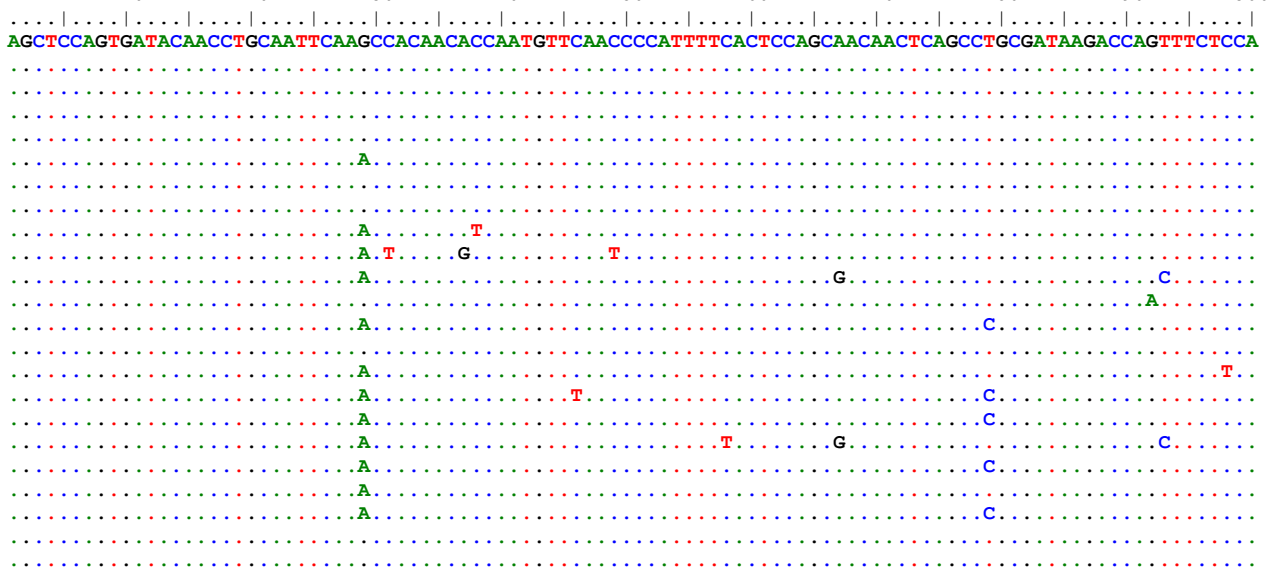




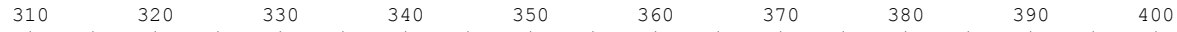

RS-67pl ATTTCAGGGGCCACACCGAGTCTTTTGGCGTTTATGGAAATGAGGATGCATCACCTAGCACCTCAAACACTTTGGTGAACACAGGAAGGATAGGGACG

$9 / 13$

$10 / 16$

$10 / 16$
$12 / 7+09$
$6 / 17-10$

7/20-10

15/7-09

$5 / 2 \overline{10}$

$5 / 29$

$6 / 1-10$

$6 / 23 \_10$

$6 / 27-10$

$7 / 110$

10/11_10

$10 / 24-10$

$12 / 18$

13/20-10

$14 / 25-10$

$15 / 3 \overline{1} 0$

$15 / 1 \overline{5} 10$

16/8_10

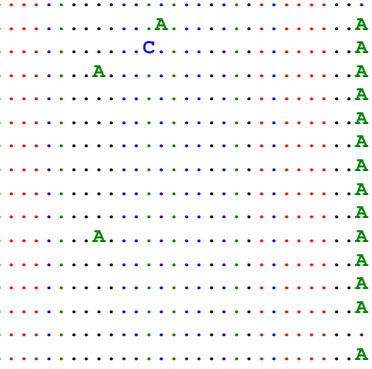

$410 \quad 420$

RS-67pl TCGATGCAGGATCGATTGGAACTTTCG

$9 / 13$

$9 / 15$

$10 / 16$

$10 / 16$

$12 / 7$-09

$6 / 17-10$

$7 / 20$

$15 / 7-09$

$5 / 210$

$5 / 29+10$

$6 / 1-10$

$6 / 2310$

$6 / 27-10$

$7 / 1-10$

10/11 10

$10 / 24$

$12 / 18$

$13 / 2010$

$14 / 25$

$15 / 310$

$16 / 15=10$ 
PRILOG 8: Sekvence PPV-D izolata sa inokulisanih, kao i zaraženih stabala iz 2010. godine upoređene sa sekvencom izolata RS-68pl

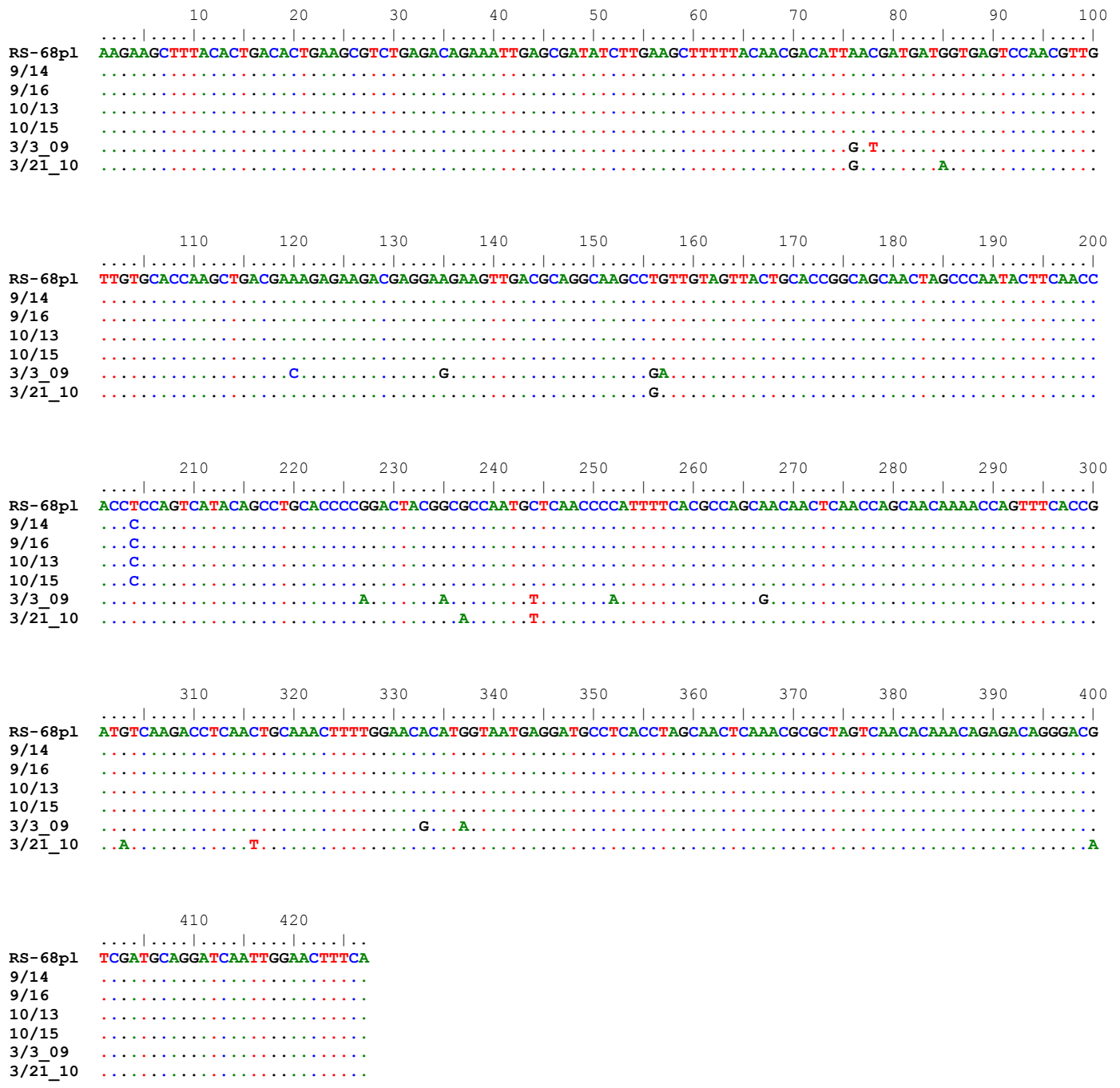


PRILOG 9: Broj uhvaćenih krilatih formi različitih vrsta lisnih vaši primenom Sticky-shoot metode u eksperimentalnom zasadu šljive u 2010. godini

\begin{tabular}{|c|c|c|c|c|c|c|c|c|c|c|c|c|c|c|c|c|c|}
\hline \multirow[b]{2}{*}{ Vrsta lisnih vaši } & \multicolumn{16}{|c|}{ Intervali nanošenja aerosola } & \multirow[b]{2}{*}{ 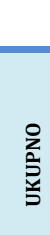 } \\
\hline & 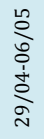 & 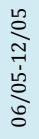 & 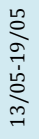 & 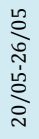 & 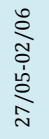 & 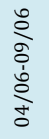 & 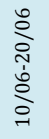 & 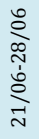 & 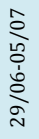 & $\begin{array}{l}\hat{0} \\
\frac{0}{2} \\
\stackrel{1}{\hat{0}} \\
\stackrel{0}{0} \\
0\end{array}$ & 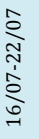 & 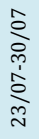 & 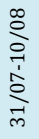 & 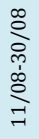 & 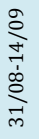 & 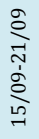 & \\
\hline Acyrthosiphon pisum & & & & & 1 & & & & & & & & & & & & 1 \\
\hline Anoecia corni & & & & & & 1 & & 2 & 3 & & & & & & & 4 & 10 \\
\hline Aphis craccivora & & & 1 & 3 & 1 & & & 2 & 1 & 1 & 1 & & & 1 & 3 & & 14 \\
\hline Aphis fabae & & & & 2 & 6 & 6 & 1 & 1 & & 1 & 1 & & & & 5 & & 23 \\
\hline Aphis gossypi & & & & & 1 & & & 1 & & & 1 & & & & 1 & & 4 \\
\hline Aphis pomi/spiraecola & 1 & & & & 1 & & & & & 2 & 4 & & & & & & 8 \\
\hline Aphis spp. & & 2 & 5 & 7 & 9 & 7 & 4 & & 1 & 4 & 2 & & & & 5 & & 46 \\
\hline Atheroides serrulatus & & & & & & 2 & & & & & & & & & & & 2 \\
\hline Aulacorthum solani & & & & 1 & & 1 & & & & & & & & & & & 2 \\
\hline Brachycaudus spp. & & & 1 & 1 & & 1 & & & & & & & & & & & 3 \\
\hline Chaitophorus sp. & & & & & & 1 & & & & & & & & & & & 1 \\
\hline Cheitosiphon sp. & & 1 & & & & & & & & & & & & & & & 1 \\
\hline Dysaphis sp. & & & & & & & & & & & & 1 & & & & & 1 \\
\hline Hyalopterus pruni & & & & & & 3 & 1 & 1 & 2 & 3 & & & & & & & 10 \\
\hline Macrosiphini & & & & & & & & & & 1 & & & & & & & 1 \\
\hline Macrosiphum sp. & & & & & & & & 1 & & & & & & & & & 1 \\
\hline Metopolophium dirhodum & & & & & 1 & & & & & & & & & & & & 1 \\
\hline Myzocallis boerneri & & 9 & 26 & 55 & 101 & 294 & & 3 & 1 & & & & & & & & 489 \\
\hline Myzocallis coryli & 5 & 3 & & & & & & & & & & & & & & & 8 \\
\hline Myzocallis spp. & 1 & 31 & 37 & 22 & 125 & 181 & 156 & 18 & 1 & 1 & 1 & 2 & & & & & 576 \\
\hline Myzus cerasi & & & & & 1 & & & & & & & & & & & & 1 \\
\hline Myzus persicae & & & 1 & 4 & & 4 & & & & & & & & & & & 9 \\
\hline Pemphigus spp. & & & & & & 1 & & 5 & & 1 & & & & & 1 & & 8 \\
\hline Peryphyllus sp. & 1 & & & & & & & & & & & & & & & & 1 \\
\hline Phorodon humuli & & & & & & & 3 & 1 & & & & & & & & & 4 \\
\hline Phyllaphis fagi & 2 & 3 & 1 & & & & 1 & & & & & & & & & & 7 \\
\hline Rhopalomyzus spp. & & & & & 2 & 1 & & & & & & & & & & & 3 \\
\hline Rhopalosiphum maidis & & & & & & & & & & 1 & & & & & & & 1 \\
\hline Rhopalosiphum nymphaeae & & & & & & 1 & & & & & & & & & & & 1 \\
\hline Rhopalosiphum padi & & & & & & & & & & & & & & & 1 & 6 & 7 \\
\hline Rhopalosiphum sp. & & & & & & & & & & & & & & & 1 & & 1 \\
\hline Schizaphis graminum & & & & & 2 & 1 & 2 & & 1 & & 1 & & & & & & 7 \\
\hline Semiaphis sp. & & 1 & & & & & & & & & & & & & & & 1 \\
\hline Sipha sp. & & & & & & & 1 & & & & & & & & & & 1 \\
\hline Sitobion avenae & & & & 1 & & 1 & & & & & & & & & & & 2 \\
\hline Tetraneura spp. & & & & & 3 & & 1 & 1 & & & & & & & 1 & 1 & 7 \\
\hline Thelaxes spp. & & 1 & & 1 & & & & & & & & & & & 1 & & 3 \\
\hline Therioaphis spp. & & & 1 & & 1 & 1 & & & & & 1 & & & & 3 & & 7 \\
\hline Therioaphis trifolii & & 8 & & & 1 & & & & & & & 1 & & & 2 & 5 & 17 \\
\hline Ukupan broj & 10 & 59 & 73 & 97 & 256 & 507 & 170 & 36 & 10 & 15 & 12 & 4 & 0 & 1 & 24 & 16 & 1289 \\
\hline
\end{tabular}


PRILOG 10: Sekvence PPV-Rec izolata sa zaraženih stabala iz 2011. godine upoređene sa sekvencom izolata RS-67pl
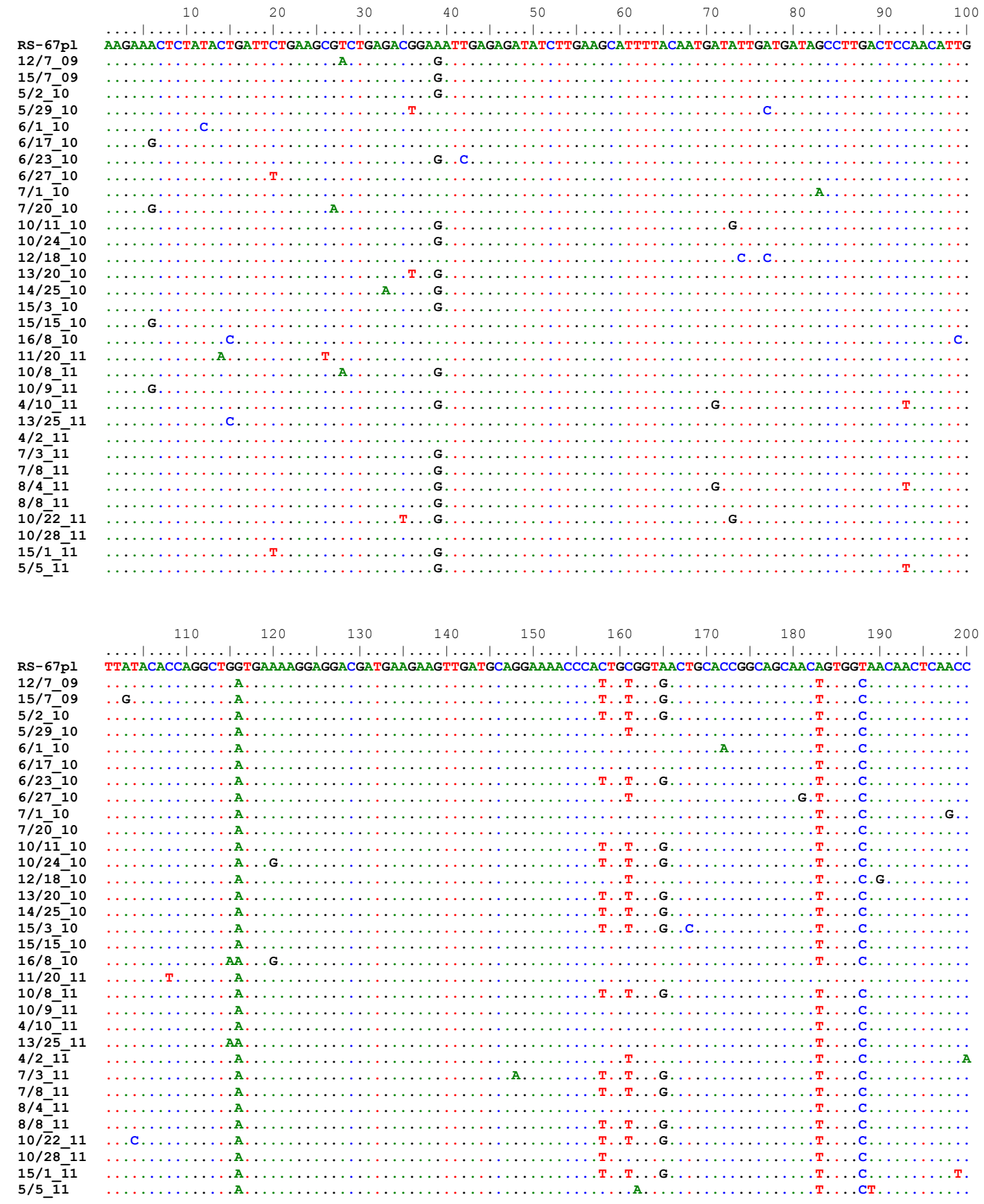
$\begin{array}{lllllllll}210 & 220 & 230 & 240 & 250 & 260 & 270 & 280 & 290\end{array}$

RS-67p1 AGCTCCAGTGATACAACCTGCAATTCAAGCCACAACACCAATGTTCAACCCCATTTTCACTCCAGCAACAACTCAGCCTGCGATA

$12 / 7$ 09

$15 / 7-09$

$5 / 210$

$5 / 29-10$

$6 / 1-10$

6/23-10

6/23-10

$7 / 1 \overline{1} 0$

(1)

10/11_10

$10 / 24$

$12 / 18$

$13 / 20-10$

$14 / 25=10$

$15 / 3 \overline{10}$

$16 / 8$ - 10

$11 / 2 \overline{0} 11$

10/8_-11

10/9 11

4/10 11

$13 / 2 \overline{5} 11$

$4 / 21 \overline{1}$

$7 / 3-1$

$7 / 8-11$

$8 / 4-11$

$10 / 2211$

$10 / 28-11$

$15 / 1 \overline{1} 1$

5/5_-11

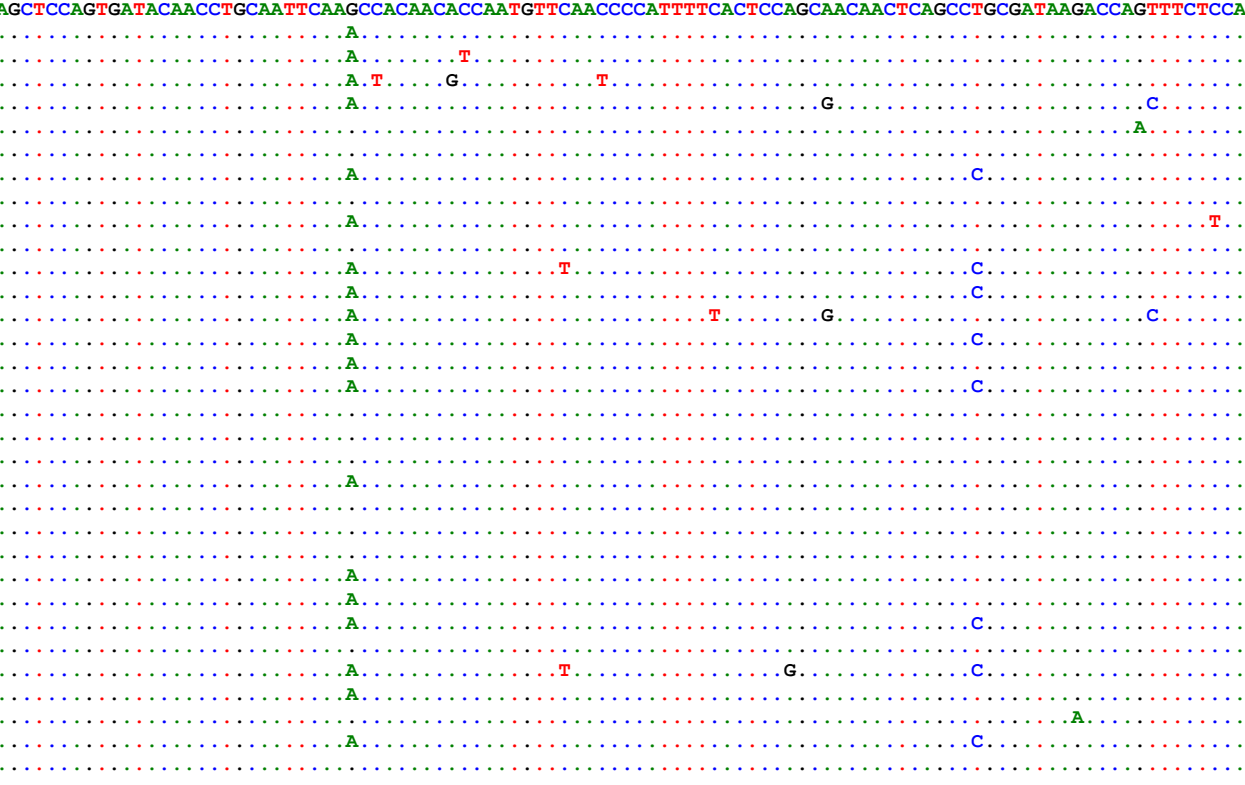

$\begin{array}{llllllllll}310 & 320 & 330 & 340 & 350 & 360 & 370 & 380 & 390 & 400\end{array}$

RS-67pl

12/7_09

$15 / 7-09$

$5 / 2-10$

$5 / 29+10$

$6 / 1-10$

6/17_10

$6 / 27-10$

$7 / 1 \overline{1} 0$

$7 / 2 \overline{0} 10$

$10 / 1 \overline{1} 10$

$10 / 24-10$

$13 / 20-10$

$14 / 25$

$15 / 310$

$15 / 1 \overline{5}$

$16 / 8 \quad \overline{1} 0$

$11 / 2 \overline{0} 11$

$10 / 8 \overline{1} 1$

$10 / 9-11$

$4 / 10^{-} 11$

$13 / 2 \overline{5} 11$

$4 / 21 \overline{1}$

$4 / 2-11$

$7 / 3-11$

$8 / 4-11$

$8 / 8^{-11}$

$1 0 \longdiv { 2 2 }$

$10 / 22-11$

5/5_ำ

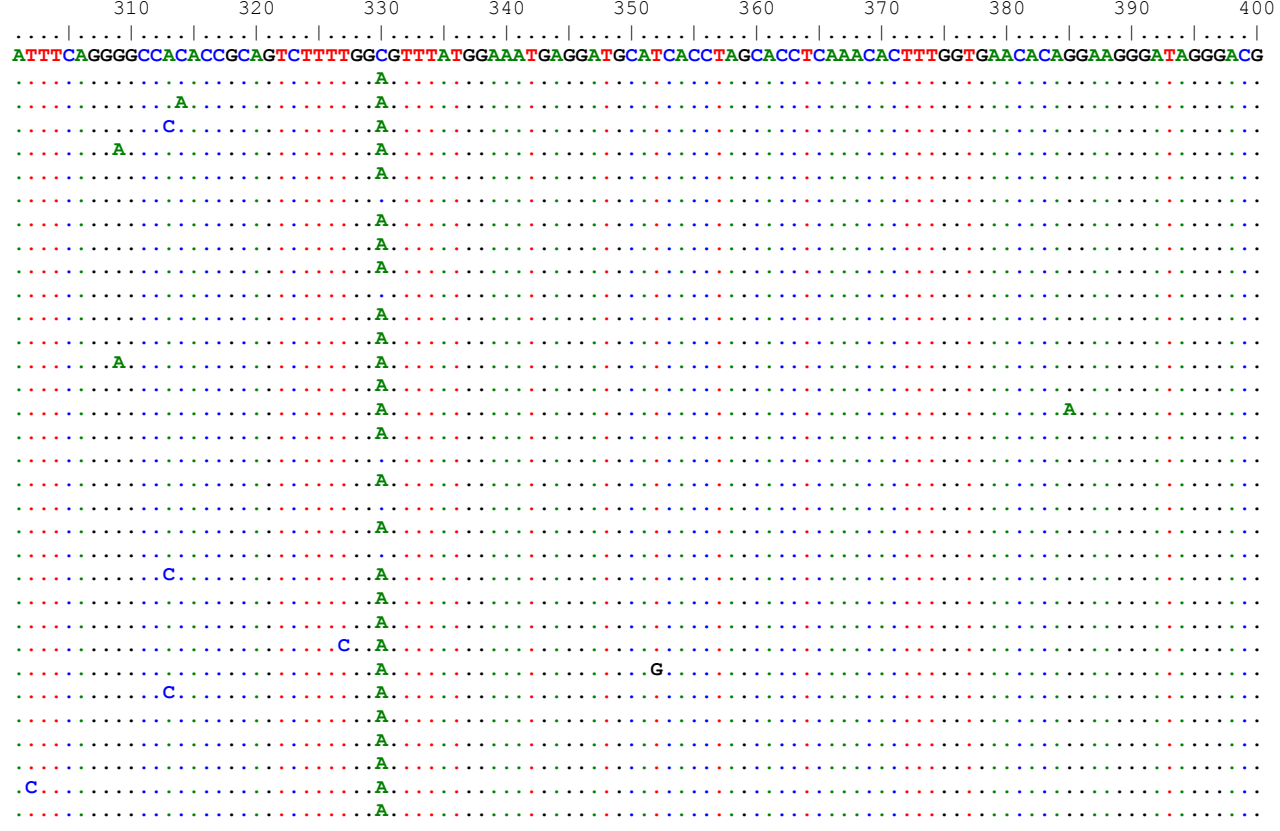


$410 \quad 420$

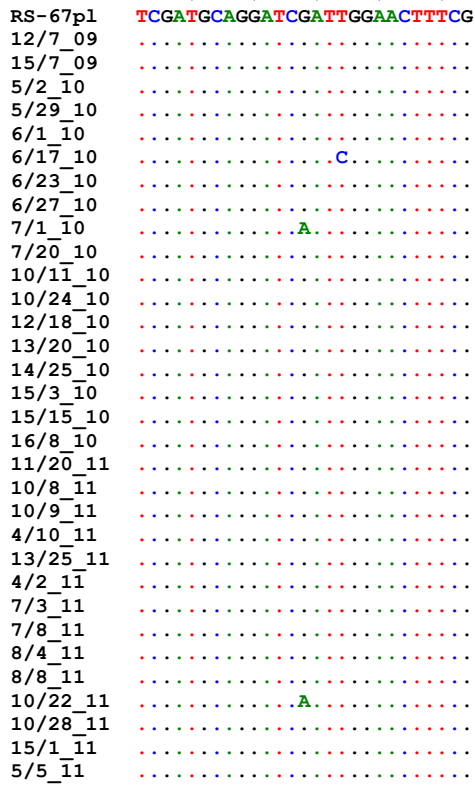


PRILOG 11: Sekvence PPV-D izolata sa zaraženih stabala iz 2011. godine upoređene sa sekvencom izolata RS-68pl
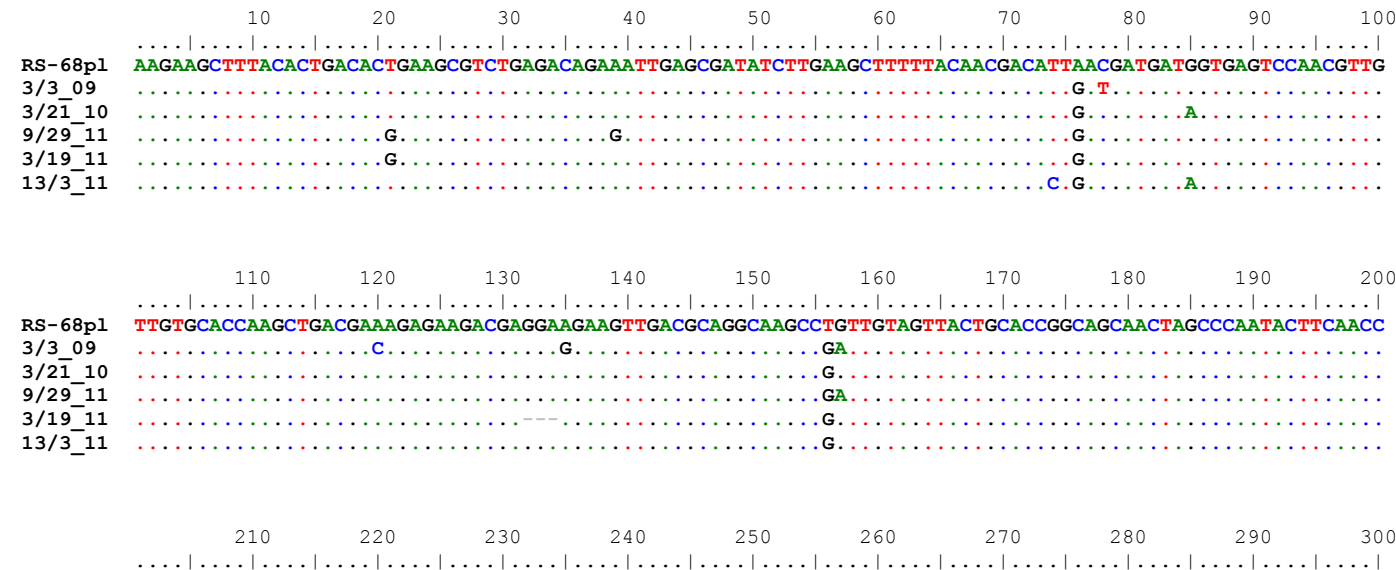
RS-68pl ACCTCCAGTCATACAGCCTGCACCCCGGACTACGGCGCAATGCTCAACCCCATTTTCACGCCAGCAACAACTCAACCAGCAACAAAACCAGTTTCACCG $3 / 309$

$3 / 2 \overline{1} 10$ $9 / 29-11$

$3 / 19-11$

$13 / 3$

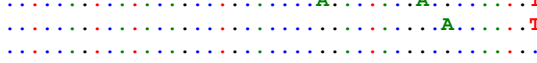

T.C.

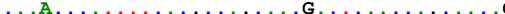

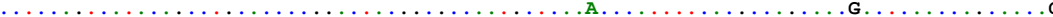

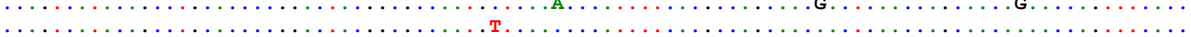

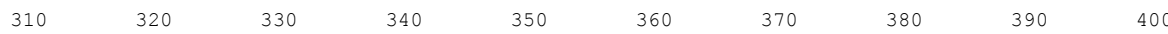

RS-68pl ATGTCAAGACCTCAACTGCAAACTTTTGGA.CACATGGTA TGAGGATGCTCACCTAGCAACTCAAACGCGCTAGTCAACACAAACAGAGACAGGGACG

$3 / 2 \overline{1} 10$

$3 / 21-10$

9/29-11

13/3 11

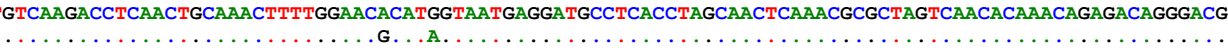
............

A

$410 \quad 420$

RS-68pl TCGATGCAGGATCAATTGGAACTTTCA

3/3_09

3/21_10

$9 / 29$

$3 / 19$

13/3 11 
PRILOG 12: Sekvence PPV izolata novozaraženih stabala šljive iz obližnjeg malog zasada

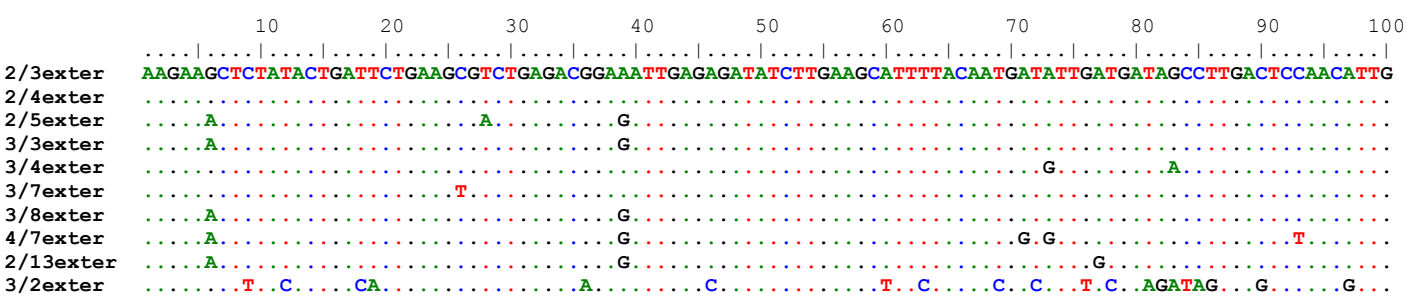

$3 / 2$ exter

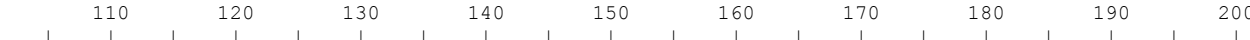
2/3exter 2/4exter

2/5exter

$3 / 3$ exter

$3 / 4$ exter

$3 / 7$ exter

$3 / 8$ exter

$4 / 7$ exter

/173exter

1/13exter

TTATACACCAGGCTGATGAAAAGAGGACGATGAAGA GTTGATGCAGGAAACCCACTGCGGTAACTGCACCGGCAGCAACTGTGGCAACAACTCAACC

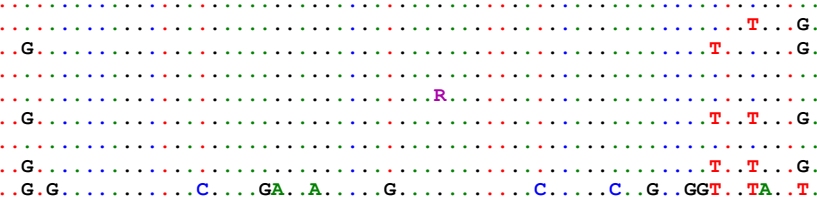

G

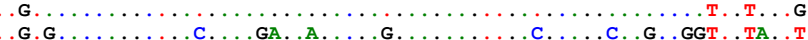

AGCC T CT

$2 / 3$ exter

2/4exter

2/5exter

$3 / 3$ exter

3/4exter

3/7exter

$3 / 8$ exter

$4 / 7$ exter

$2 / 13$ exter 3/2exter

210
220 $230 \quad 240 \quad 250 \quad 260 \quad 270 \quad 280 \quad 290 \quad 300$

AGCTCCAGTGATACAACCTGCAATTCAAGCCACAACACCAATGTTCAACCCATTTTCACTCCAGCAACAACTCAGCCTGCGATA $\ldots|\ldots| \ldots|\ldots| \ldots \mid$

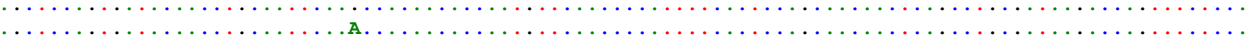

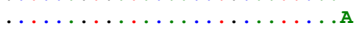

……

(n)

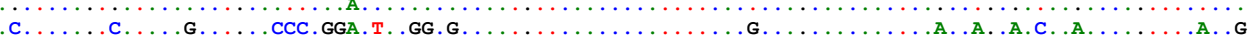

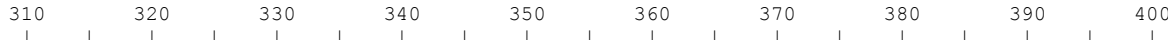

$2 / 3$ exter

$2 / 4$ exter

$2 / 5$ exter

$3 / 3$ exter

$3 / 4$ exter

$3 / 8$ exter

$4 / 7$ exter

$3 / 13$ exter

(1) ATTTCAGGGGCACACCGA GTCTTTTGGCGTTTATGGAAATGAGGATGCATCACCTAGCACCTCAAACACTTTGGTGAACACAGGAAGGGATAGGGACG W.

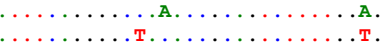
W.

(1)

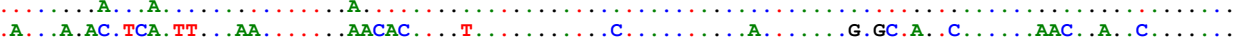

$410 \quad 420$

2/3exter

$2 / 4$ exter

$2 / 5$ exter

$3 / 3$ exter

$3 / 4$ exter

3/7exter

$3 / 8$ exter

$4 / 7$ exter

$2 / 13$ exter

3/2exter

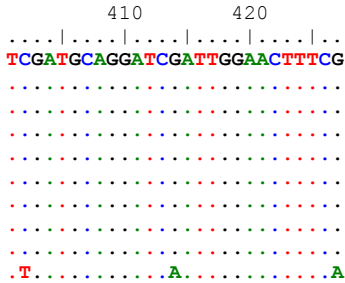


PRILOG 13: Broj uhvaćenih krilatih formi različitih vrsta lisnih vaši primenom Sticky-shoot metode u eksperimentalnom zasadu šljive u 2011. godini

\begin{tabular}{|c|c|c|c|c|c|c|c|c|c|c|c|c|c|c|c|c|c|}
\hline \multirow[b]{2}{*}{ Vrsta lisnih vaši } & \multicolumn{16}{|c|}{ Intervali nanošenja aerosola } & \multirow[b]{2}{*}{ 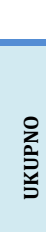 } \\
\hline & $\begin{array}{l}\stackrel{2}{\infty} \\
\stackrel{\infty}{0} \\
\stackrel{+}{+} \\
\stackrel{\infty}{\infty}\end{array}$ & $\begin{array}{l}\stackrel{2}{\rho} \\
b \\
\frac{1}{1} \\
\stackrel{\rho}{\sigma} \\
\stackrel{0}{0}\end{array}$ & 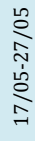 & 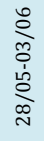 & 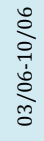 & $\begin{array}{l}\stackrel{2}{\circ} \\
\stackrel{N}{1} \\
\stackrel{0}{0} \\
0\end{array}$ & 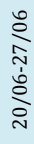 & 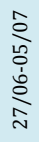 & 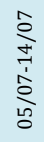 & 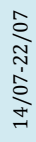 & 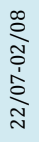 & 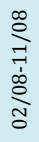 & 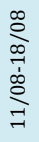 & 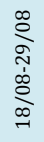 & $\begin{array}{l}\stackrel{2}{2} \\
\text { oे } \\
\text { o } \\
\stackrel{2}{\sigma} \\
\text { N }\end{array}$ & $\begin{array}{l}\stackrel{\text { }}{\text { }} \\
\stackrel{2}{o} \\
\stackrel{\partial}{\sigma}\end{array}$ & \\
\hline Acyrthosiphon pisum & & 1 & 1 & & & & & & & & & & & & & & 2 \\
\hline Anoecia corni & & & & & 1 & 1 & 1 & & & & & & 2 & & & 2 & 7 \\
\hline Anoecia spp. & & & & & & & & 2 & & & & & & & & & 2 \\
\hline Aphis craccivora & 1 & & & 2 & & 1 & 3 & 2 & 1 & & & 3 & 1 & & & & 14 \\
\hline Aphis fabae & & 2 & 1 & 1 & & 5 & & 2 & & & & & & & & & 11 \\
\hline Aphis gossypi & & & & & & & 1 & & & & & & & & & & 1 \\
\hline Aphis pomi/spiraecola & & 3 & 6 & & & & 1 & 2 & & & 1 & & & & & & 13 \\
\hline Aphis spp. & & 7 & 12 & 3 & 11 & 8 & 6 & 4 & 9 & 3 & 8 & 18 & 9 & 2 & 4 & & 104 \\
\hline Atheroides serrulatus & & 1 & & & & 1 & & & & & & & & & & & 2 \\
\hline Betulaphis sp. & & & & & & 1 & & & & & & & & & & & 1 \\
\hline Brachycaudus helychisi & & 1 & & & 1 & 2 & 2 & 2 & & & & & & 4 & & & 12 \\
\hline Brachycaudus sp. & & & & & 1 & & & & & & & & & & & & 1 \\
\hline Brevicoryne brassicae & & & & & & & & 1 & & & & 3 & & & & & 4 \\
\hline Capitophorus horni & & & & & & & & 6 & & & & & & & & & 6 \\
\hline Capitophorus spp. & & 1 & 2 & & & & 1 & & & & & & & & & & 4 \\
\hline Cavariella aegopodii & & & & & & & 1 & & & & & & & & & & 1 \\
\hline Chaitophorus hippophaes & & & & & & & 1 & & & & & & & & & & 1 \\
\hline Dysaphis sp. & & & & & & & & & & & & & & & 1 & & 1 \\
\hline Hyadaphis sp. & & & & & 1 & & & & & & & & & & & & 1 \\
\hline Hyalopterus pruni & & & 1 & & & 1 & & & & 1 & & & & 3 & & & 6 \\
\hline Hyperomyzus lactucae & & & & & & 3 & & & & & & & & & & & 3 \\
\hline Hyperomyzus sp. & & & & & & & & & & & & & & & 1 & & 1 \\
\hline Macrosiphum spp. & & & & 2 & & 1 & & 1 & & & & & & & & & 4 \\
\hline Macrosiphini & & & & 1 & & & & 1 & & 1 & & & & & & & 3 \\
\hline Myzocallis spp. & & & & 1 & & & 2 & 3 & & & & & & & & & 6 \\
\hline Pemphigus spp. & & & & 1 & & 1 & 1 & 2 & & & 1 & & 1 & 1 & 4 & 5 & 17 \\
\hline Phorodon humuli & & & 2 & & 6 & & & & & & & & & & & & 8 \\
\hline Rhopalosiphum maidis & & & 1 & & & & & & & & & & & & & & 1 \\
\hline Rhopalosiphum nymphaeae & & & & & 2 & & & & & & & & & & & & 2 \\
\hline Rhopalosiphum padi & & & & & & 1 & 2 & & & & & 1 & & 2 & 2 & 1 & 9 \\
\hline Saltusaphis sp. & & & & & 1 & & & & & & & & & & & & 1 \\
\hline Schizaphis graminum & & & 1 & 1 & & & 1 & 1 & & & & & 1 & & & & 5 \\
\hline Semiaphis spp. & & & & & & & & 1 & & & & & & & 1 & & 2 \\
\hline Sipha maydis & & & & & & & & & & & & & & 3 & & & 3 \\
\hline Sipha sp. & & & & & & 1 & & 2 & & & & & & & & & 3 \\
\hline Sitobion avenae & & & & & & & & 2 & & & & & & & & & 2 \\
\hline Tetraneura spp. & & & & & & & & 1 & & & & & & & & 1 & 2 \\
\hline Thelaxes spp. & & 1 & 1 & & & & & 1 & & & & & & 2 & & & 5 \\
\hline Therioaphis spp. & & & & & 1 & & & & & & & & & & 2 & & 3 \\
\hline Therioaphis trifolii & & & 1 & & & 2 & & 3 & & 2 & 4 & 1 & 2 & & & & 15 \\
\hline Tinocallis platani & & & & & & 1 & & & & & & & & & & & 1 \\
\hline UKUPNO & 1 & 17 & 29 & 12 & 25 & 30 & 23 & 39 & 10 & 7 & 14 & 26 & 16 & 17 & 15 & 9 & 290 \\
\hline
\end{tabular}




\section{BIOGRAFIJA AUTORA}

Darko Jevremović je rođen 28. marta 1977. godine u Ćupriji. Po završenoj Gimnaziji u Jagodini upisao je Agronomski fakultet u Čačku gde je diplomirao 2002. godine sa prosečnom ocenom 9,33 i stekao zvanje diplomirani inženjer agronomije opšteg smera. Magistarsku tezu pod naslovom „Molekularna karakterizacija i genetička struktura izolata virusa šarke šljive (Plum pox virus) u Srbiji“ odbranio je 2008. godine na Poljoprivrednom fakultetu u Zemunu i stekao zvanje magistar biotehničkih nauka - oblast agronomskih nauka - fitopatologije.

Od 2003. godine zaposlen je u Institutu za voćarstvo u Čačku. Obavio je kratke specijalizacije u: Institutu za vinogradarstvo u Koneljanu u Italiji (2005. godine), INRA Institutu u Monpeljeu, Francuska (2006. i 2010. godine) i IVIA Institutu u Valensiji, Španija (2008. godine).

Učestvovao je na 4 projekta finansiranih od strane Ministarstva prosvete i nauke, a trenutno je angažovan na realizaciji aktivnosti dva projekta: „Stvaranje i očuvanje genetičkog potencijala kontenintalnih vrsta voćaka“ i „Uticaj sorte i uslova gajenja na sadržaj bioaktivnih komponenti jagodastog i koštičavog voća i dobijanje biološki vrednijih proizvoda poboljšanim i novim tehnologijama“.

Učestvovao je na realizaciji 6 projekata finansiranih od strane Ministarstva poljoprivrede, trgovine, šumarstva i vodoprivrede.

Mr Jevremović je do sada učestvovao i na tri međunarodna projekta: ECONET (2005-2006): Evaluation des risques epidemiologiques lies a l'emergence de variants du Plum pox virus (virose de la Sharka) en Europe; SHARCO FP7 (20082012): Containment of Sharka virus in view of EU-expansion; i EXCHANGE 3 (2010-2011): The development of an integrated pest, disease and natural hazard management system in agricultural crops.

Rukovodilkac je bilatelalnog projekta sa Republikom Francuskom „Risk assessment of the emergence and further spreading of new Plum pox virus recombinants (Sharka disease)“ (2012-2013).

Do sada je u saradnji sa drugim autorima objavio preko 60 bibliografskih jedinica. 
Прилог 1.

\section{Изјава о ауторству}

Потписани-а _ ДАРКО ЈЕВРЕМОВИЋ

број уписа 1295

\section{Изјављујем}

да је докторска дисертација под насловом

„PACПРОСТРАҢЕНОСТ PPV-D И PPV-REC COJEBA BИРУCA ШАРКЕ ШЉИВЕ (Plum pox virus) У СРБИЈИ И ДИНАМИКА ЊИХОВОГ ШИРЕЬА У ЗАСАДУ ШЉИВE“"

- резултат сопственог истраживачког рада,

- да предложена дисертација у целини ни у деловима није била предложена за добијање било које дипломе према студијским програмима других високошколских установа,

- да су резултати коректно наведени и

- да нисам кршио/да ауторска права и користио интелектуалну својину других лица.

Потпис докторанда

У Београду, јуни, 2012. године

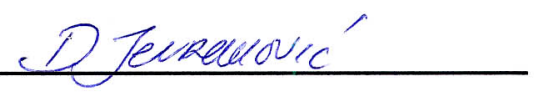




\section{Прилог 2.}

\section{Изјава о истоветности штампане и електронске верзије докторског рада}

Име и презиме аутора ДАРКО ЈЕВРЕМОВИЋ

Број уписа 1295

Студијски програм

Наслов рада „РАСПРОСТРАҢЕНОСТ PPV-D И PPV-Rec COJEBA ВИРУCA ШАРКЕ ШЉИВЕ (Plum pOX virus) У СРБИЈИ И ДИНАМИКА ЊИХОВОГ ШИРЕЊА У ЗАСАДУ ШЉИВЕ"

Ментор проф. Др. Бранка Крстић

Потписани _ ДАРКО ЈЕВРЕМОВИЋ

изјављујем да је штампана верзија мог докторског рада истоветна електронској верзији коју сам предао/ла за објављивање на порталу Дигиталног репозиторијума Универзитета у Београду.

Дозвољавам да се објаве моји лични подаци везани за добијање академског звања доктора наука, као што су име и презиме, година и место рођења и датум одбране рада.

Ови лични подаци могу се објавити на мрежним страницама дигиталне библиотеке, у електронском каталогу и у публикацијама Универзитета у Београду.

Потпис докторанда

У Београду, __јуни, 2012. године

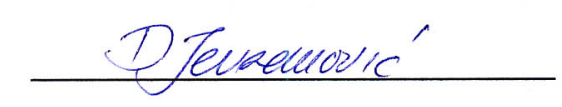




\section{Прилог 3.}

\section{Изјава о коришћењу}

Овлашћујем Универзитетску библиотеку „Светозар Марковић“ да у Дигитални репозиторијум Универзитета у Београду унесе моју докторску дисертацију под насловом:

„PАСПРОСТРАҢЕНОСТ PPV-D И PPV-REC COJEBA BИРУCA ШАРКЕ ШЉИВЕ (Plum pox virus) У СРБИЈИ И ДИНАМИКА ЊИХОВОГ ШИРЕЊА У ЗАСАДУ ШЉИВЕ"

која је моје ауторско дело.

Дисертацију са свим прилозима предао/ла сам у електронском формату погодном за трајно архивирање.

Моју докторску дисертацију похрањену у Дигитални репозиторијум Универзитета у Београду могу да користе сви који поштују одредбе садржане у одабраном типу лиценце Креативне заједнице (Creative Commons) за коју сам се одлучио/ла.

1. Ауторство

2. Ауторство - некомерцијално

3. Ауторство - некомерцијално - без прераде

4. Ауторство - некомерцијално - делити под истим условима

5. Ауторство - без прераде

6. Ауторство - делити под истим условима

(Молимо да заокружите само једну од шест понуђених лиценци, кратак опис лиценци дат је на полеђини листа).

Потпис докторанда

У Београду, _еунни, 2012. године

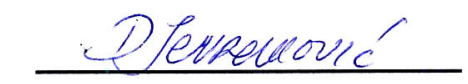

